TEXAS TECH UNIVERSITY

3 1295013472948 
DEPARTMENT OF THE INTERIOR

UNITED STATES GEOLOGICAL SURVEY

GEORGE OTIS SMITH, DIRECTOR

BULLETIN 521

\section{THE COMMERCIAL MARBLES OF WESTERN VERMONT}

BY

T. NELSON DALE

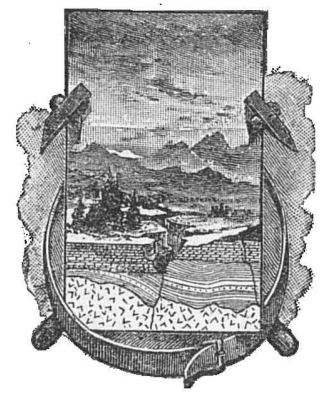

WASHINGTON

GOVERNMENT PRINTING OFFICE

1912 



\section{CONTENTS.}

Page.

The work of Vermont geologists $\ldots \ldots \ldots \ldots \ldots \ldots \ldots \ldots \ldots \ldots \ldots \ldots \ldots \ldots \ldots$

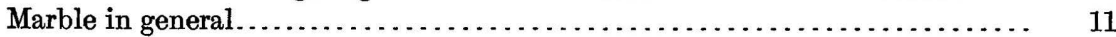

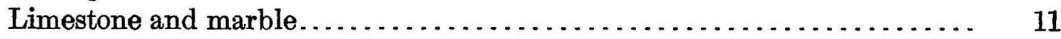

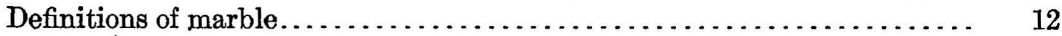

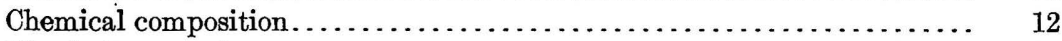

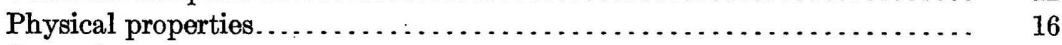

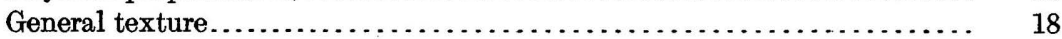

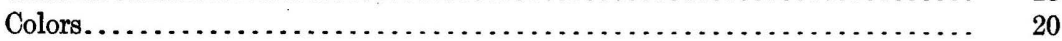

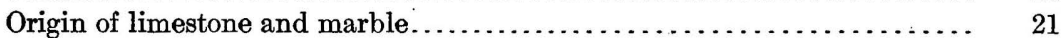

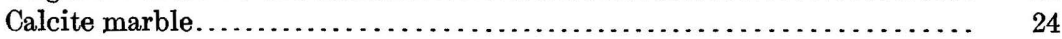

Dolomite marble...................................... 27

Relation of calcite marble to dolomite in Vermont. . . . . . . . . . . . . . 29

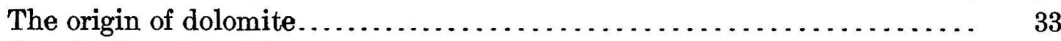

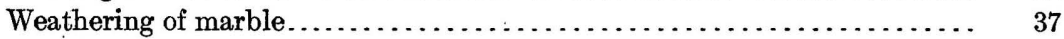

The marbles of western Vermont. . . . . . . . . . . . . . . . . . . . $\quad 39$

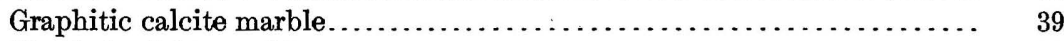

Clouded calcite marble............................ 40

Muscovitic calcite marble............................... 41

Actinolitic calcite marble............................... 43

Dolomite marbles of Lake Champlain....................... 43

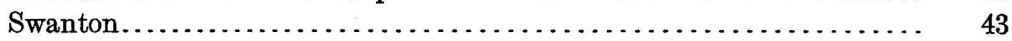

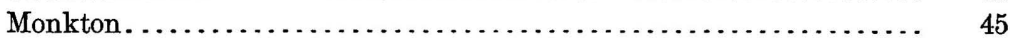

Dolomite marbles of Proctor and Pittsford . . . . . . . . . . . . $46 \ldots \ldots \ldots$

Unmetamorphic calcite marble of Isle la Motte................... 47

"Manchester breccia"................................. 48

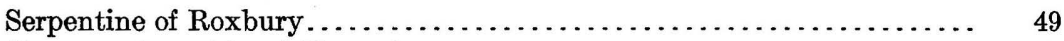

Chrome mica schist of Shrewsbury..................... 50

Microscopic texture of the calcite marbles................... 51

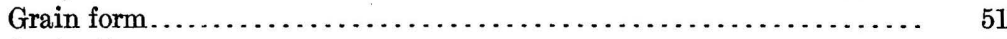

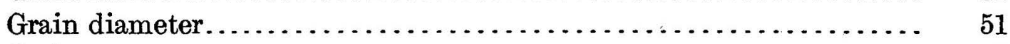

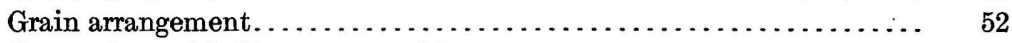

Comparison with European marbles........................ 53

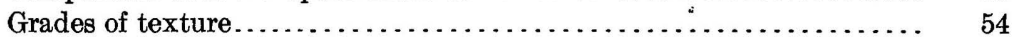

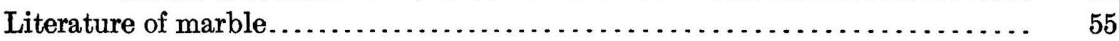

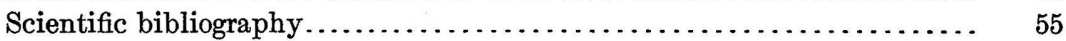

Economic bibliography .................................... 56

Publications on Vermont marbles. . . . . . . . . . . . . . . . . $\quad 59$

The marble belts of western Vermont. ........................ 60

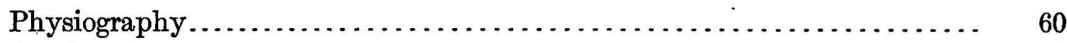

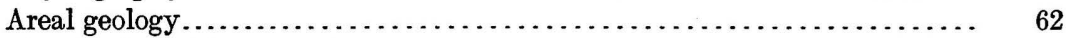

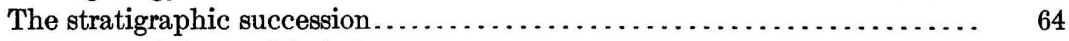

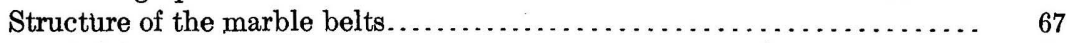

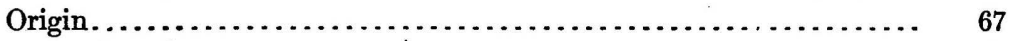

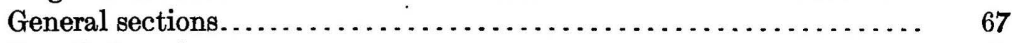

Detailed sections..................................... 69 
The marble belts of western Vermont-Continued.

Structure of the marble belts-Continued.

Structural notes........................................ 69

Equinox and Bear mountains.......................... 69

South Dorset....................................... $\quad 69$

Dorset Mountain .................................. $\quad 70$

West Rutland anticline................................ $\quad 70$

Schist ridge west of Proctor and Fowler.................. 71

Structure north and south of Center Rutland................ 71

Trap dikes in the marble belts............................. $\quad 72$

Geologic history of the marble belts......................... 74

Geologic principles governing the marble belts.................. 77

Continuity of the stratum................................ 77

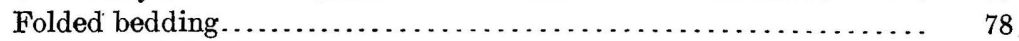

Character of the folds...................................... 78

Lateral inclination of the folds.......................... $\quad 78$

Pitch of the folds..................................... $\quad 79$

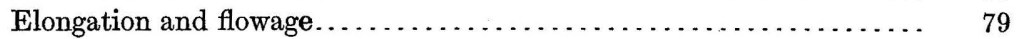

Pinching out of beds.................................... 80

Relation of marble to schist.............................. $\quad 80$

Bedding and cleavage in schist........................... . 81

Cleavage in marble..................................... 82

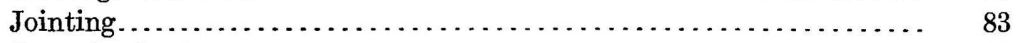

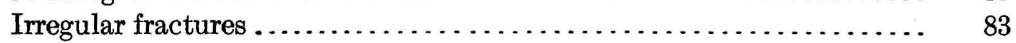

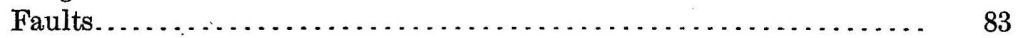

Dikes and their effects................................... 83

Erosion of folds........................................ 84

Underground solution.................................. 84

Effects of glaciation................................... 85

Protection by clay beds............................... 85

The marble beds............................................ 86

East side of West Rutland anticline....................... $\quad 86$

West side of West Rutland anticline....................... 87

Proctor................................................ 89

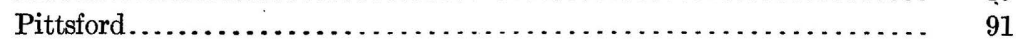

South Dorset.......................................... 93

Dorset Mountain, Owls Head, and Green Peak................ 94

The entire marble section.................................. 95

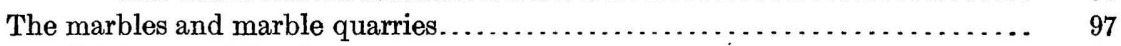

Calcite and dolomite marbles. . . . . . . . . . . . . . . . . . . . . . . . . 97

Manchester............................................ 97

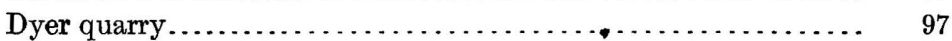

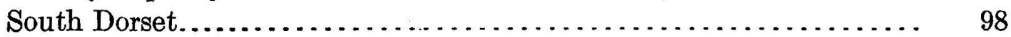

Bennington quarry.................................... 98

Kent \& Root quarry ...................................... 98

Continental Marble Co.'s quarry.......................... 98

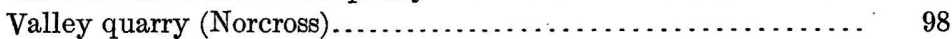

Plateau quarry................................... $\quad 100$

Owls Head quarries................................ 102

Green Peak quarries.................................... 103

Deaf Joe quarry ................................... 103

Blue Ledge quarry ............................... 104

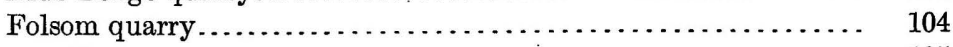

East Dorset Italian quarry.......................... 105 
The marbles and marble quarries-Continued.

Calcite and dolomite marbles-Continued. Page.

Quarries on Dorset Mountain.............................. 105

Freedley quarries.................................. 105

White Stone Brook quarry ............................ 107

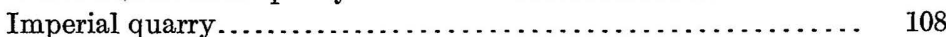

New York quarry .................................... 109

Clarendon quarries...................................... 110

Clarendon Valley quarry............................ $\quad 110$

Clarendon quarry.................................... 111

Rutland quarries.................................... 112

Foley prospect....................................... 112

West Rutland quarries, west side........................ 113

Eastman quarry...................................... 113

Morgan quarry........................................ 116

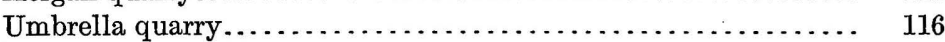

Rutland-Florence quarry.............................. 116

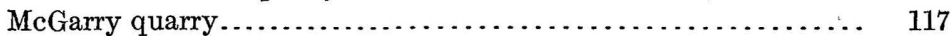

West Rutiand quarries, east side.......................... 117

Vermont Marble Co.'s West Rutland quarries................ 117

Albertson quarry................................... 123

True Blue quarry ................................... 124

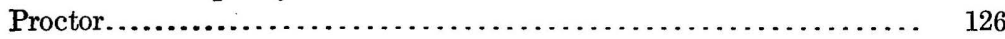

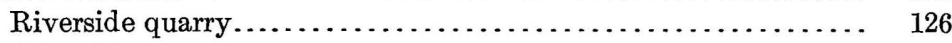

Columbian quarry................................... 127

Proctor quarry .................................... 127

Parker \& Pinckney prospect......................... $\quad 128$

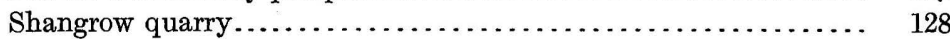

Pittsford................................................... 129

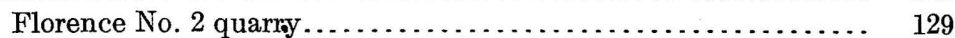

Prospect west of Florence No. 2 quarry................... 130

Turner quarry .................................... $\quad 130$

Florence No. 1 (Hogback) quarry ..................... 131

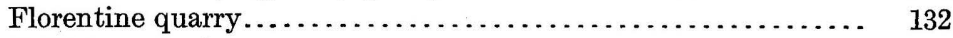

Hollister quarries................................. 133

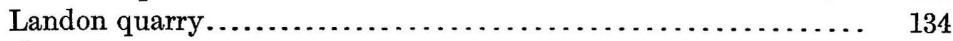

Brandon............................................... 135

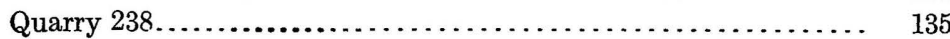

Brandon Italian quarry................................ 135

Brandon Italian High Street quarry ................... 137

Goodell quarry....................................... 137

Connell quarry ..................................... 138

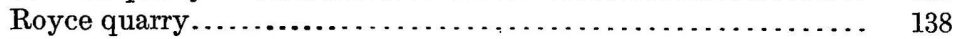

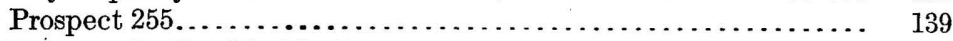

Vermont Italian Marble Co.'s quarry ....................... 139

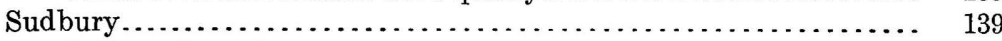

Sudbury breccia prospect........................... 139

Middlebury........................................... 139

Middlebury Marble Co.'s quarry ....................... 139

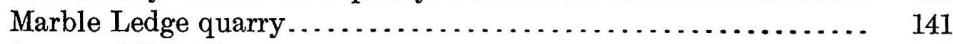

Monkton and Bristol................................... 141

Vermont Marble Co.'s Monkton quarry .................... 141

Columbian Marble Co.'s Monkton quarry................... 141

Chapin prospect..................................... 142

Jimmo prospect................................. 142 
The marbles and marble quarries-Continued.

Calcite and dolomite marbles-Continued. Page.

Swanton............................................. 142

Isle la Motte.......................................... 145

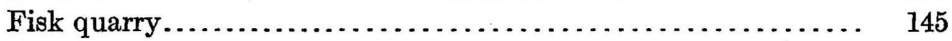

Lime marbles............................................... 146

Ira and Leicester.......................................... 146

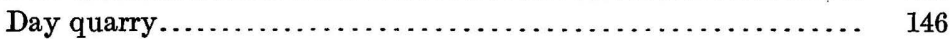

Huntley quarry..................................... 147

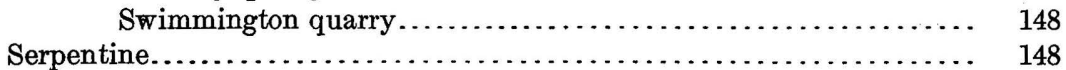

Roxbury............................................ 148

Classification of Vermont marbles............................ 149

Economic classification.................................. 149

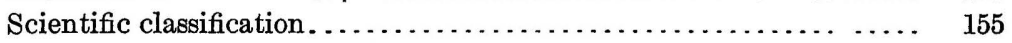

Relative values of Vermont marbles.......................... 155

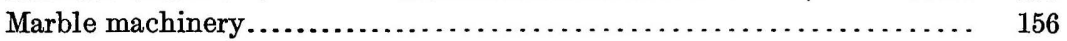

Adaptations of the marbles of western Vermont................... 156

General observations and prognostications........................ 157

Scientific prospecting for marble............................... 159

Testing of marble.......................................... 160

Glossary of technical terms.................................... 162

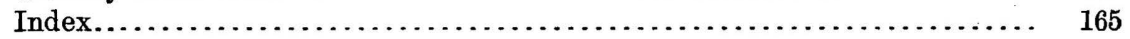




\section{ILLUSTRATIONS.}

Plate I. Geologic map of marble belts of western Vermont south of Salisbury.

II. General sections across the marble belts...................

III. Detailed sections across portions of the marble belts.............

IV. Geologic map of West Rutland belt of marble ....................

V. $A$, Graphitic calcite marble from True Blue quarry, West Rutland, showing planes of bedding and of slip cleavage laden with graphite; $B$, hematitic dolomite from Swanton.......................

VI. $A$, Plicated muscovitic calcite marble from West Rutland; $B$, plicated clouded calcite marble from New Hollister quarry, Pittsford.

VII. Pilasters of actinolitic calcite marble from Valley quarry, South Dorset .........................................

VIII. $A$. $a$, Serpentine from Roxbury; $b$, Muscovitic and chloritic calcite marble from Eastman quarry, West Rutland; $c$, "Jasper" marble from Swanton; $B, a$, marble breccia from Dyer quarry, Manchester; $b$, Graphitic calcite marble from Albertson quarry, West Rutland.

Page.

24

24

30

40

41

44

IX. View across the marble belt in Pittsford.................... 62

X. A, Plateau quarry, South Dorset, and block for monolithic column; $B$, tunnel of New York quarry, Dorset Mountain, Danby, showing joints near trap dike..............................

XI. Memorial Continental Hall, Washington, D. C., with marble columns from South Dorset.............................. 102

XII. View from south wall of Gilson quarry, West Rutland, showing part of east limb of West Rutland anticline.....................

XIII. Portrait statue of white calcite marble, "light Rutland Italian," at Seattle, Wash . ....................................

XIV. A, Columns of "second statuary Rutland" calcite marble, Chicago, Ill.; $B$, mantel and wainscoting of muscovitic calcite marble from

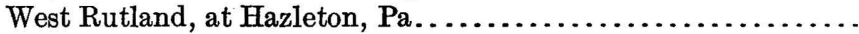

XV. $A$, South wall of True Blue quarry, West Rutland, showing bed of dolomite passing into a series of nodules; $B$, glaciated beds of gray marble at Florentine quarry, Pittsford..................

XVI. $A$, Glacial furrow in white marble, protected by clay beds, Pittsford; $B$, pinched fold of white marble prolonged by flowage, Owls Head quarries, South Dorset...............................

XVII. Effect of underground solution, Florence No. 1 quarry, Pittsford...

FIGURE 1. Thin section of white calcite marble with flexed twinning planes...

2. Sections of marine snail shells in marble from West Rutland.......

3. Thin section of a grain of white calcite marble showing typical calcite twinning.

4. Thin section of two grains of dolomite marble with typical dolomite twinning.

5. Interbedded calcite marble and dolomite, quarry near Owls Head..

6. Thin section of graphitic calcite marble showing elongate texture, from West Rutland 
Figure 7. Thin section of quartzose dolomitic and sericitic calcite marble from Brandon.................................... 42

8. Thin section of hematitic quartzose dolomite from Swanton....... 44

9. Thin section of carbonaceous unmetamorphic calcite marble from Isle la Motte......................................... 47

10. Bottle-shaped fold in marble near Brandon.................... 78

11. Overturned marble folds, Lenox, Mass...................... 79

12. Bedding and cleavage in schist on Dorset and Bear mountains.... 81

13. Thin section of "white" calcite marble from Norcross-West Valley quarry, South Dorset............................ 99

14. Marble folds in quarries near Owls Head................... 103

15. Thin section of white calcite marble from White Stone Brook quarry, Dorset Mountain............................ 108

16. Thin section of white calcite marble, "statuary Rutland"...... 119

17. Course of east limb of West Rutland anticline.................. 122

18. Approximate structure at True Blue quarry................... 125

19. Irregular joints and fractures, Florence No. 2 quarry............. 129

20. Minute dolomite bed in lower mottled marble, "Pittsford Italian". 131

21. Thin section of coarser part of clouded calcite marble from Hollister quarry...................................... 134

22. Thin section of calcitic part of clouded marble from Brandon Italian quarry...................................... 136

23. Structure at Brandon Italian quarry ...................... 136

24. Thin section of white calcite marble from abandoned quarry of Middlebury Marble Co.............................. 140

25. Thin section of marble from Huntley quarry, Leicester Junction... 148 



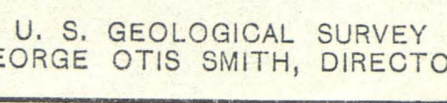

LEGEND A

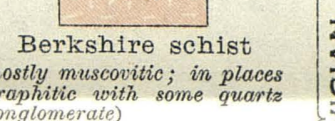

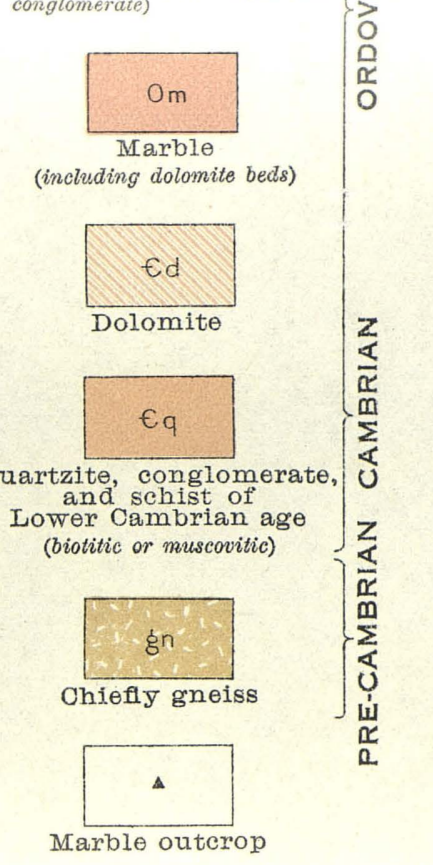

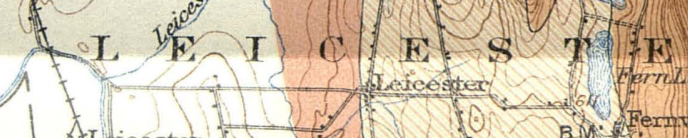

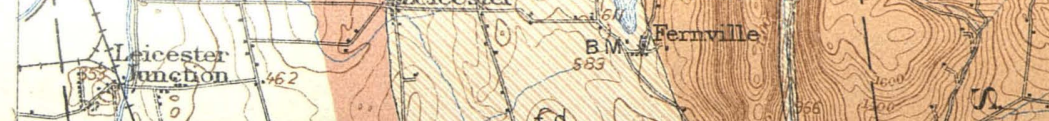

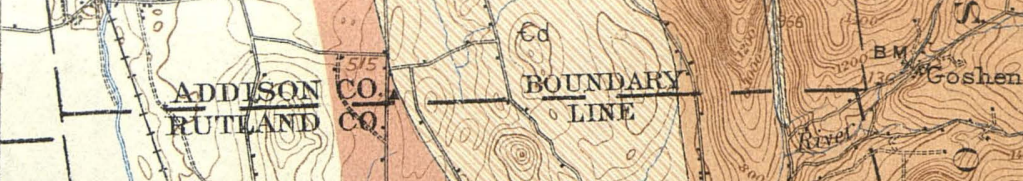
2) 1 . $k$.

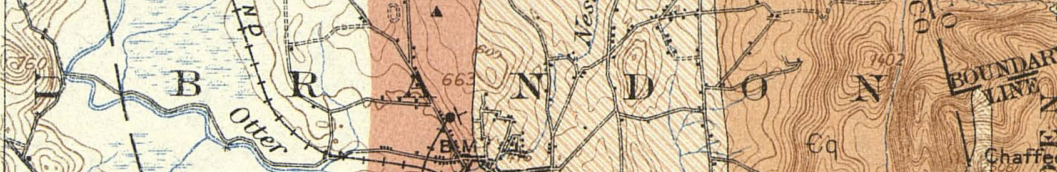

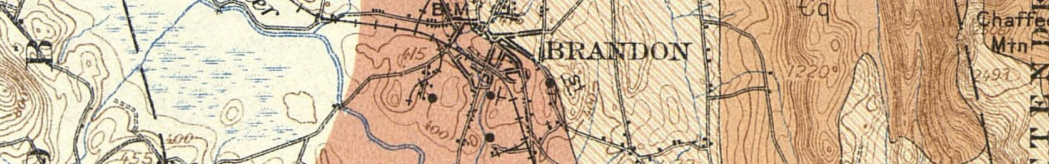
a. 2 - J

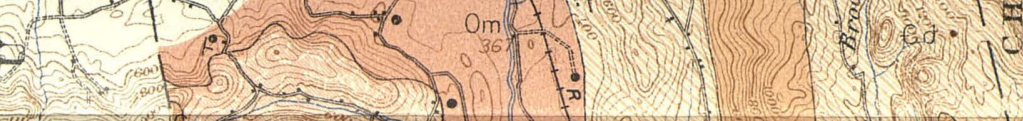

Marble quarry

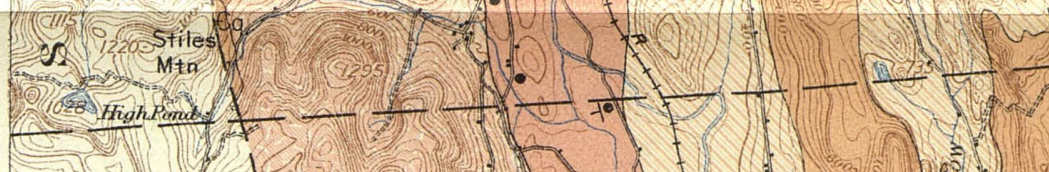

$\frac{\perp}{\text { strikse and atip of ber }}$

$\underset{\text { Horizontal bea }}{\infty}$

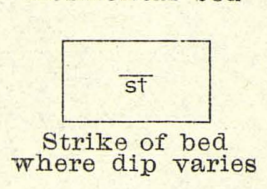

Stritke of bed
where dipp varies
$\rightarrow$

$\underset{\text { Pitch of folds }}{\longrightarrow}$

$\frac{F}{P \text { pault }}$

Possbile fault

\begin{tabular}{|c|}
\hline$c$ \\
\hline care \\
\hline
\end{tabular} s.t.

- 5 (5)

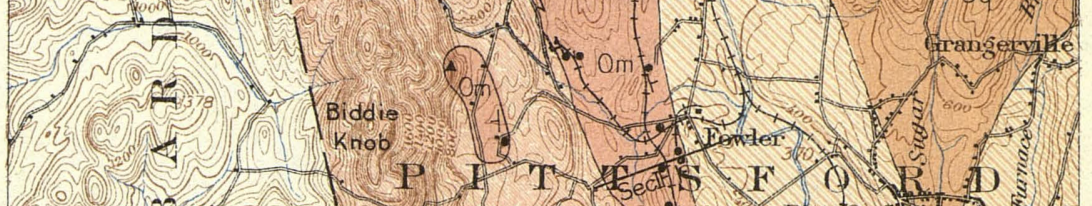

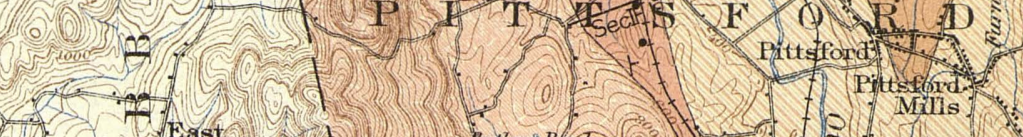

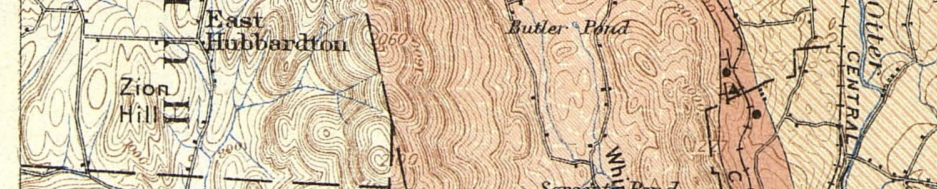
-

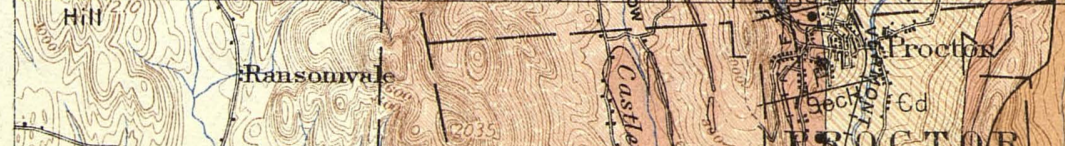

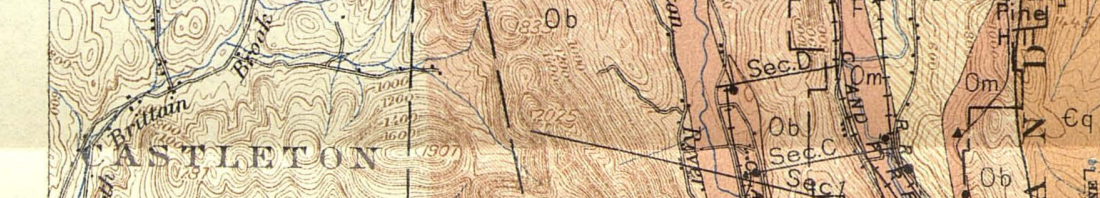
(15) ${ }^{2}+$ (c) frit.

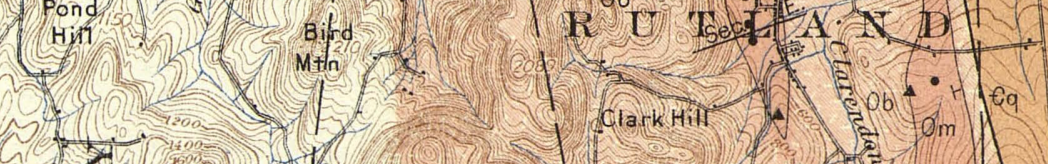

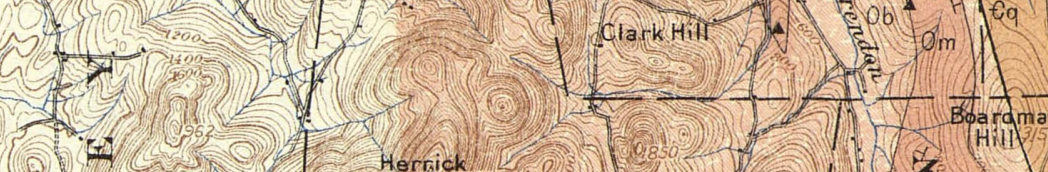

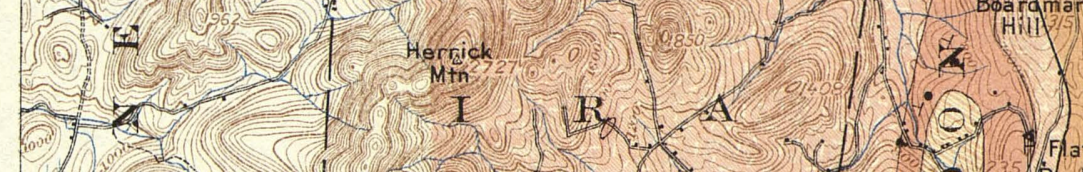

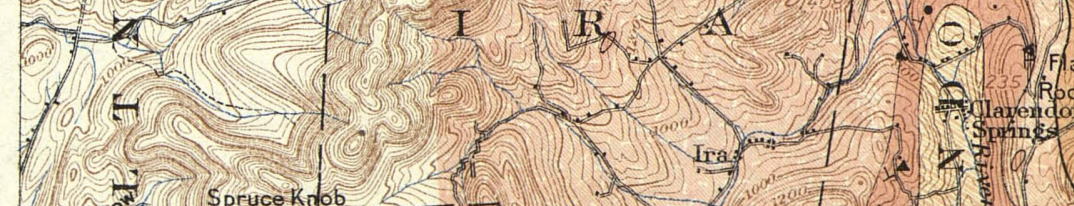

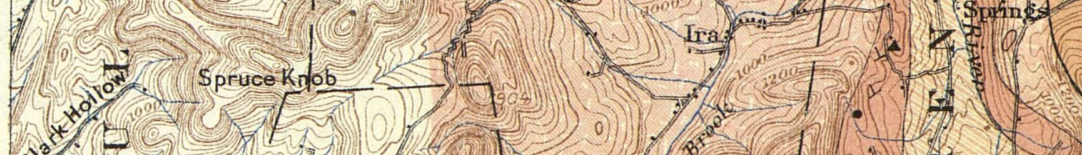
(5)

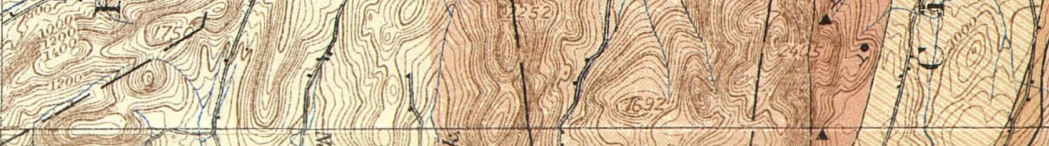
Ninf

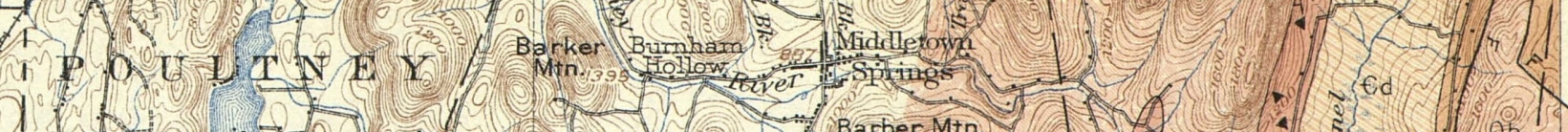

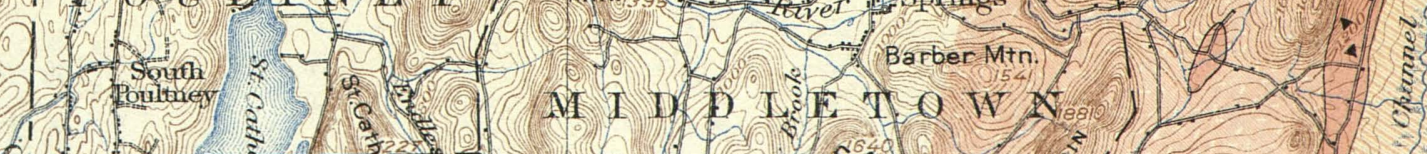
7. 6) 5 (1)

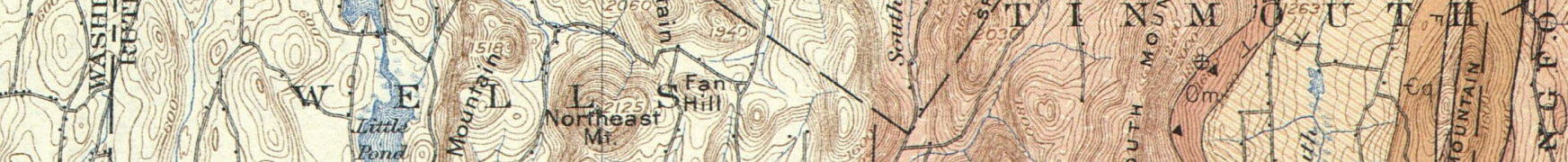
1)

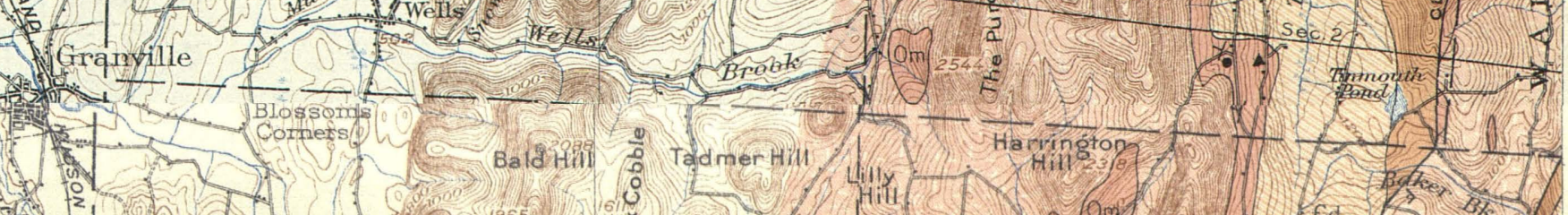

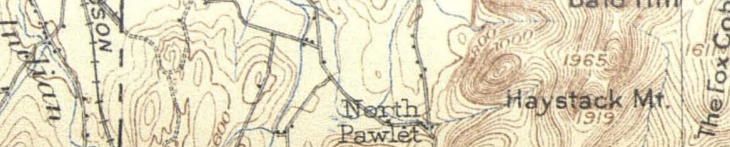
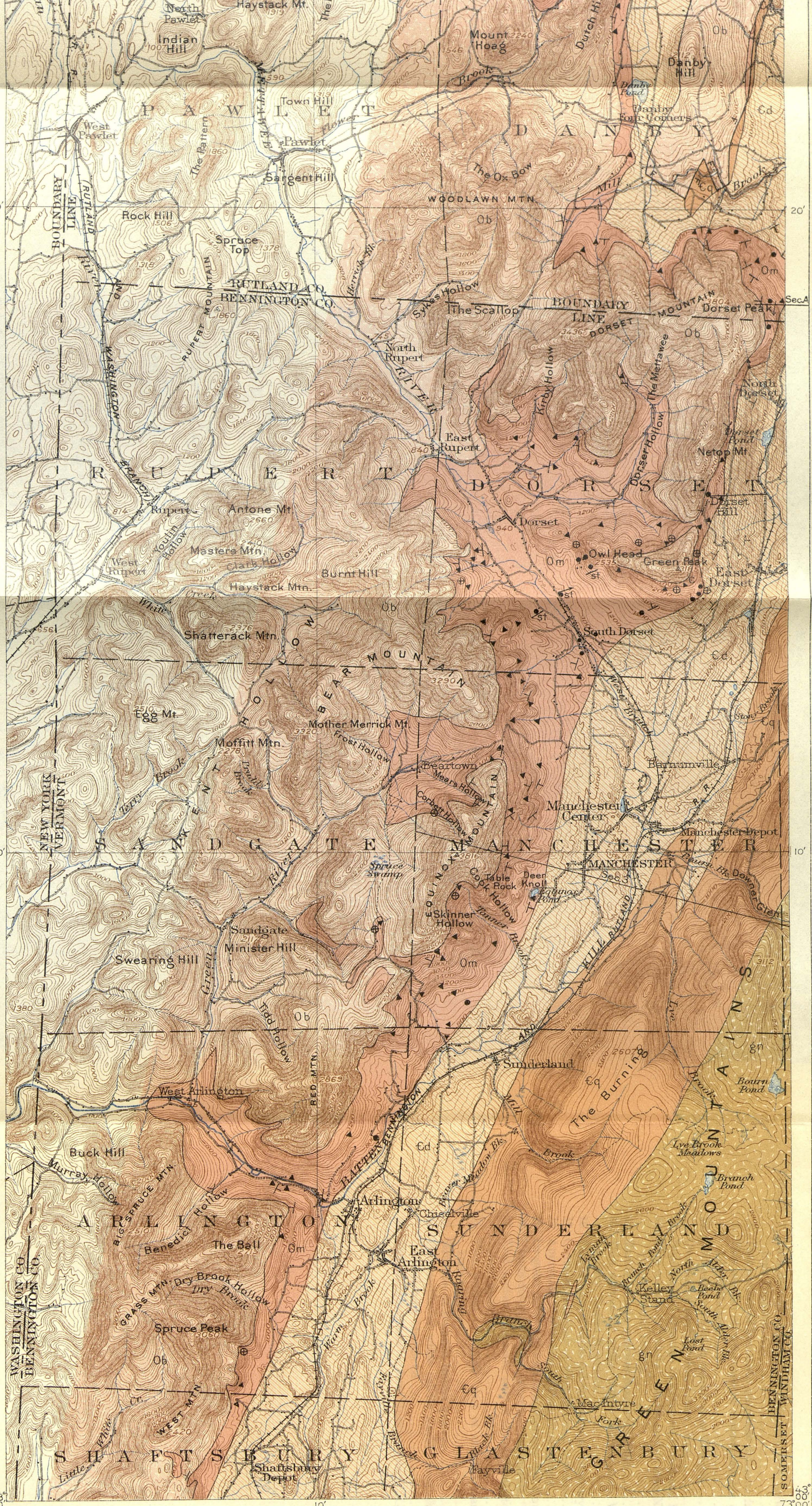

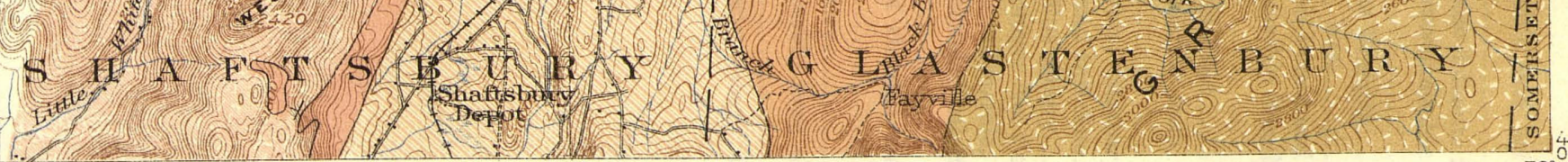




\title{
THE COMMERCIAL MARBLES OF WESTERN VERMONT.
}

\author{
By T. Nelson Dale.
}

\section{INTRODUCTION.}

This publication has a twofold object-to bring the science of geology to bear upon the problems of the marble industry in western Vermont and briefly to make known the more important scientific results obtained in the course of the mapping of the marble belts of that part of the State and in the study of its marbles.

The marble district specially considered lies west of the Green Mountain Range in Bennington, Rutland, and Addison counties, but the reddish dolomite marble quarried at Swanton, in Franklin County, and the black calcite marble quarried on Isle la Motte, in Grand Isle County, are also described. The green serpentine of Roxbury, nearly in the center of the State, in Washington County, and the chrome mica schist of Shrewsbury, in Rutland County, have also been included. The bulletin covers all the quarries of commercial marble that were in operation in the State in 1910. The marble deposits on the east side of the Green Mountain axis, including the small disused-quarries in Orange County, are not here considered.

The field work was done by the writer in parts of the summers of $1888,1899,1900,1903$, and 1904. Mr. F. H. Moffit spent the summers of 1899 and 1900 and a month in 1902 on the areal and structural geology of the marble belt and adjacent schist masses in Arlington, Sandgate, Manchester, Dorset, Danby, and Tinmouth. His maps, notes, sections, and specimens have been used in the preparation of this bulletin. Mr. N. C. Dale assisted the writer in the summer of 1903. The writer also spent most of the summer of 1910 in visiting all the active marble quarries of the State and in otherwise completing the work begun in 1888 .

The notes on the texture of marble (pp. 51-54) are based on the study of 200 thin sections.

Mr. George Steiger, of the Geological Survey, has contributed a quantitative determination of the graphite in the gray marble of West Rutland. Mr. W. T. Schaller, also of the Survey, has made a qualitative examination of a dolomitic bed near Brandon, and he and $\mathrm{Mr}$. 
J. S. Diller have made an examination of the chrome mica schist marble of Shrewsbury. Mr. E. S. Larsen has also made a few petrographic determinations.

The marble companies have materially aided the work by placing their core-drill records at the writer's service, by facilitating his investigations, and by furnishing sawed cubes for thin sections and polished specimens.

The elementary geologic principles which should guide the quarryman and the prospector in the marble belts of western Vermont are outlined on pages $77-85$.

In order to render the bulletin more widely serviceable as few technical terms as possible have been used, even in the more scientific parts. A glossary of such technical terms as have unavoidably been used will be found on pages 162-164.

It is proposed to supplement this bulletin by one on the marbles of eastern Vermont.

\section{THE WORK OF VERMONT GEOLOGISTS.}

Much work has been done by geologists of Vermont on the geology of its marbles.

The State report of Hitchcock and Hager, published in 1861, laid the foundation for all future work. Next in importance were the discoveries of Rev. Augustus Wing, published by James D. Dana in 1877 , determining the geologic age and structural relation of various parts of the marble and limestone areas. Then came the general summary of the geologic features of the marble belt by President Ezra Brainerd, in 1885, and in connection with it the interesting economic papers published the same year by Prof. Henry M. Seely on the marble industry of western New England and its early beginnings in Vermont. These were followed, in 1898 to 1008 , by several annual reports by Prof. George H. Perkins, State geologist, in which the location and characteristics of the quarries were given, the marble firms and plants noted, and the colors and shades of all the marbles carefully described. The report for 1908 also contains two important papers by Prof. Perkins on the geology of Franklin and Chittenden counties and the formation to which the "Champlain marbles" belong. The same report also includes a paper by George E. Edson on the geology of Swanton. Finally, the State geologist's report for 1910 contains a brief reference to the marble industry and some photographs of unusual folds in the great marble belt in Leicester.

The design of this bulletin is not to supplant or duplicate, but to complement the work of the geologists of the State. It is expected that this will be accomplished not only by means of the geologic maps and sections and the results of the microscopic study of the marbles 
but also by furnishing those engaged in the marble industry a brief key to the structural geology of the marble beds.

The reader will be frequently referred to the reports of the State geologists for information on special points. A bibliography of Vermont marbles will be found on pages 59-60.

\section{MARBLE IN GENERAL.}

\section{LIMESTONE AND MARBLE.}

If a chemical precipitate of carbonate of lime is examined microscopically, it will be found to consist of irregular, infinitesimal granules of uncrystalline matter. When analyzed, this material will be found to have essentially the composition of what is technically known as marble or crystalline limestone. A thin section of marble, when placed under a microscope, is seen to be an aggregate of translucent to transparent crystalline plates, generally of irregular outline, of calcite or dolomite, with the rhombohedral cleavage characteristic of these minerals, and also generally crossed by twinning planes. These twinning planes, which are so conspicuous in thin sections of marble, are due to the growth of two crystals in such juxtaposition (but not parallel) that there is a uniform mathematical relation between the axes of the two crystals. The twinning plane seen in the crystalline grain of a thin section of marble is the plane along which the two crystals meet. But as this twinning process generally repeats itself in the same crystalline mass or particle, a single microscopic grain may contain several such planes. The difference between a collection of individual crystals of calcite and a piece of calcite marble is that the former, like granulated sugar, consists of complete crystals, whereas in calcite marble the crystals have been formed so close to one another that no one crystal has been able to complete itself. There has been no space for the formation of the faces of individual crystals.

Many so-called granular limestones when examined microscopically are found to consist of exceedingly minute, irregular plates of polarizing but untwinned calcite. Such limestones are really part-way marbles.

A few specimens of limestones were examined microscopically to throw light on the relation of limestone and marble:

A very fine-grained limestone, Chickamauga (201), collected by Dr. C. W. Hayes near Attalla, Ala., with flintlike fracture, brownish-gray color, and strong effervescence with $\mathrm{HCl}$, consists of irregular polarizing particles 0.0028 to 0.006 millimeter in diameter, with sparse polarizing plates, some of them of rhombic form (dolomite), 0.008 to 0.02 millimeter in diameter, and sections of fossils.

Another limestone, Chickamauga (202), collected also by Dr. Hayes near White Cliff Springs, near Starrs Mountain, in Tennessee, has a very fine texture, is dark brown in color, effervesces strongly, is finely veined and fossiliferous. In thin section this rock shows irregular nodules of very fine polarizing granules of irregular form in a 
matrix of polarizing calcite particles. Nodules and matrix are crossed by fine veins of calcite. The fossil sections polarize.

An oolitic limestone from Short Creek, Galena, Kans., with a light-brownish cement and strong effervescence, consists of slightly flattened spherules, 0.02 to 0.05 millimeter in diameter, of polarizing irregular grains ( 0.006 to 0.014 millimeter) lying in a matrix of polarizing and twinned calcite plates.

It is usually assumed that natural chalk is uncrystalline, but the crystalline nature of chalk has been determined by Kauffmann and verified by Renard. ${ }^{1}$

The difference between one of these semigranular limestones and a true marble appears in polishing. The marble alone yields a brilliant surface, which is due to the effect of light upon its uniformly crystalline particles. ${ }^{2}$

\section{DEFINITIONS OF MARBLE}

The distinctions indicated lead to the following definitions:

Marble in the technical sense is a rock consisting mainly of crystalline particles of calcite or dolomite or of both. But marble in the commercial sense includes a wide variety of stones and even some of very different composition and history. A Vermont serpentine is described on page 49 and a chrome mica schist on page 50. Both are commercial "marbles."

\section{CHEMICAI COMPOSITION.}

The chemical composition of marble varies primarily according as it consists of calcite or of dolomite or of an admixture of both. White calcite marble is almost entirely carbonate of lime. In white dolomite marble carbonate of magnesia takes the place of part of the carbonate of lime. As the colored marbles of these two sorts contain small percentages of other minerals (graphite, quartz, hematite, limonite, magnetite, pyrite, muscovite, actinolite, tremolite, etc.), their analyses differ slightly from those of the white marbles.

A few reliable analyses of typical American and European marbles follow.

\section{Analysis of white calcite marble from West Rutland, $V t{ }^{3}$}

Insolublo . . . . . . . . . . . . . . . . . . . . . . . . . . . . . .

8.00

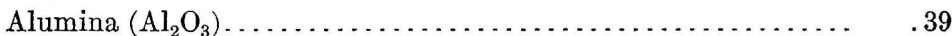

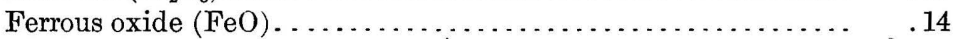

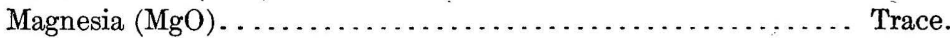

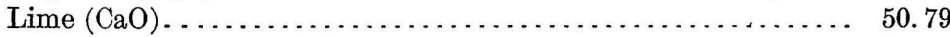

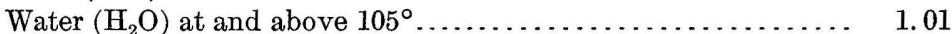

Carbon dioxide $\left(\mathrm{CO}_{2}\right) \ldots \ldots \ldots \ldots \ldots \ldots \ldots \ldots \ldots \ldots \ldots \ldots \ldots \ldots, \quad 39.80$

100.13

\footnotetext{
1 Renard, A. F., Des caractères distinctifs de la dolomite et de la calcite dans les roches calcaires et dolomitiques du calcaire carbonifère de Belgique: Bull. Acad. roy. Belgique, vol. 47, 1879, p. 555.

$2 \mathrm{See}$, for a discussion of the effect of light on polished stone surfaces, Seipp, H., Italienische Materialstudien, Stuttgart, 1911, pp. 76-105.

3 By L. G. Eakins, Bull. U. S. Geol. Survey No. 419, 1910, record No. 1213, p. 189.
} 
Analysis of white calcite marble, slightly mottled with gray, from the Columbian quarry, Proctor, Vt. ${ }^{1}$

Calcium carbonate $\left(\mathrm{CaCO}_{3}\right)$

98. 37

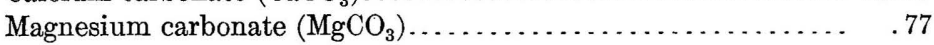

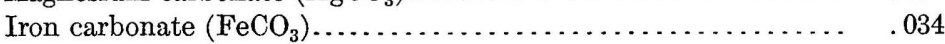

Manganese and aluminum oxides...................... . .005

Siliceous matter insoluble in acid. . . . . . . . . . . . . . . . . 63

Organic matter. ..................................... 08

99.889

As is shown on page 40 , these clouded marbles contain minute lenses and beds of dolomite, which account for the $\mathrm{MgCO}_{3}$

Analysis of white dolomite marble from Lee, Mass. $^{2}$

Insoluble

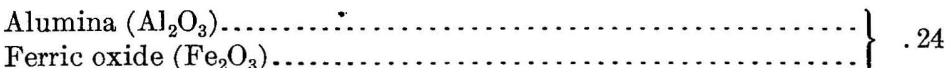

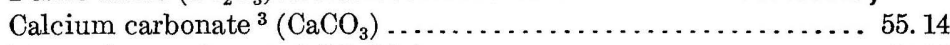

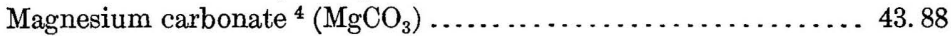

Analyses of Norwegian dolomite marbles. ${ }^{a}$

\begin{tabular}{|c|c|c|}
\hline & 1 & 2 \\
\hline \multirow[t]{2}{*}{ 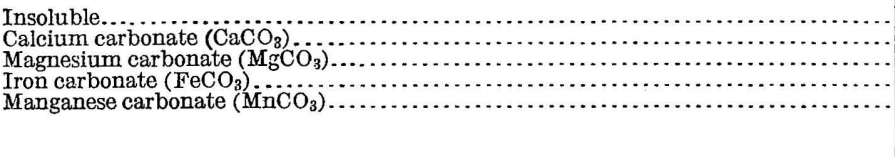 } & $\begin{array}{l}0.106 \\
54.05 \\
45.93 \\
.086 \\
.032\end{array}$ & $\begin{array}{r}0.46 \\
54.16 \\
45.09 \\
.32 \\
-. .3\end{array}$ \\
\hline & 100. 204 & 100.03 \\
\hline
\end{tabular}

$a$ Vogt, J.H. L., Norsk Marmor, 1897, p. 20. 1, Cream colored, from Hammarfald, R $\phi$ svik; 2, white,from Hemnæs Seljeli.

The following are two analyses of calcite marbles from the quarries worked by the ancient Greeks:

Analyses of Greek marbles. ${ }^{a}$

\begin{tabular}{|c|c|c|}
\hline$\cdot$ & 1 & 2 \\
\hline \multirow[t]{2}{*}{ 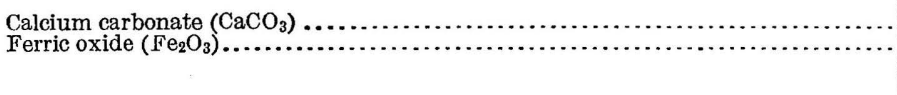 } & $\begin{array}{r}100.002 \\
.122\end{array}$ & $\begin{aligned} 100.09 \\
-10.0\end{aligned}$ \\
\hline & 100.124 & 100.09 \\
\hline
\end{tabular}

$a$ Lepsius, G. R., Griechische Marmorstudien, Berlin, 1890, pp. 18, 29. 1, "Lower white Pentelicon" marble from Mount Pentelicon, northeast of Athens, milk-white color; 2 "Lower white Attic marble" from Agrilesa Valley, $2 \frac{1}{2}$ miles north of Cape Sunium or 25 miles southeast of Athens, light bluish gray tint.

Lepsius states that the Pentelicon marble contains a few grains of quartz and scales of muscovite and chlorite, some pyrite with a zone

${ }^{1}$ By S. L. Penfield, Yale University, Twentieth Ann. Rept. U. S. Geol. Survey, pt. 6, continued, 1899, p. 447.

2 By E. A. Schneider, Bull. U. S. Geol. Survey No. 419, 1910, record No. 1279, p. 189.

3 Recalculated from $\mathrm{CaO}$ and $\mathrm{CO}_{2}$ of original.

4 Recalculated from $\mathrm{MgO}$ and $\mathrm{CO}_{2}$ of original. 
of limonite stains, and more rarely very minute grains of magnetite. The golden-brownish film noticeable on the Parthenon and other Greek structures made of this marble is attributed to this content of $\mathrm{Fe}_{4} \mathrm{O}_{9} \mathrm{H}_{6}$. In contrast with this he finds that the marble of the Agrilesa Valley, which is chemically pure calcium carbonate, forms no such crust in ancient sculptures.

Analysis of white Norwegian calcite marble from Velfjorden, Troviken. ${ }^{1}$

Calcium carbonate $\left(\mathrm{CaCO}_{3}\right) \ldots \ldots \ldots \ldots \ldots \ldots \ldots \ldots \ldots \ldots . . \ldots 9.27$

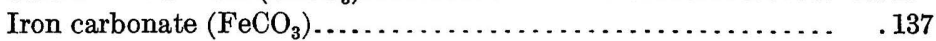

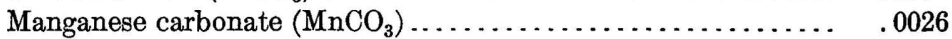

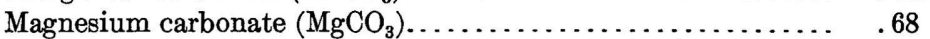

Insoluble..............................................

Analysis of Carrara marble. ${ }^{2}$

$\overline{100.86}$

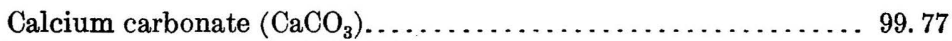

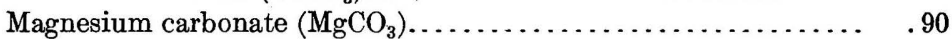

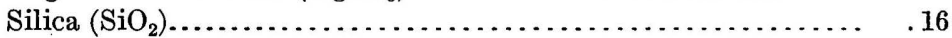

Alumina and iron sesquioxide $\left(\mathrm{Al}_{2} \mathrm{O}_{3}, \mathrm{Fe}_{2} \mathrm{O}_{3}\right) \ldots \ldots \ldots \ldots \ldots \ldots \ldots . .08$

99.91

Giampaoli ${ }^{3}$ gives for Carrara marble: Calcium carbonate $\left(\mathrm{CaCO}_{3}\right)$, extremes 98 to 99 per cent; magnesium carbonate $\left(\mathrm{MgCO}_{3}\right)$, maximum 0.9 per cent; silica $\left(\mathrm{SiO}_{2}\right)$, maximum 1.0 per cent.

Analyses of Carrara and Tyrolese marbles. ${ }^{a}$

\begin{tabular}{|c|c|c|c|}
\hline & \multirow[b]{2}{*}{$\begin{array}{c}\text { Carrara, } \\
\text { white } \\
\text { mottled. }\end{array}$} & \multicolumn{2}{|c|}{ Schlanders, Tyrol. } \\
\hline & & $\begin{array}{l}\text { Mottled, } \\
\text { coarse. }\end{array}$ & $\begin{array}{l}\text { White to } \\
\text { grayish, } \\
\text { very } \\
\text { hard. }\end{array}$ \\
\hline 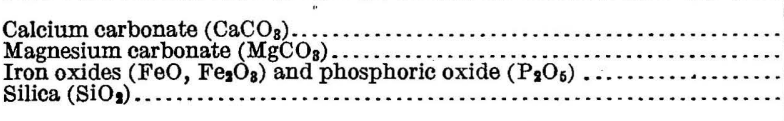 & $\begin{array}{r}99.236 \\
.284 \\
.251 \\
\end{array}$ & $\begin{array}{r}99.010 \\
.521 \\
.062 \\
\end{array}$ & $\begin{array}{r}97.040 \\
2.109 \\
.360 \\
\text { Trace. }\end{array}$ \\
\hline Specific gravity at $16.25^{\circ} \mathrm{C} \ldots$. & $\begin{array}{r}99.771 \\
2.732\end{array}$ & $\begin{array}{r}99.593 \\
2.700\end{array}$ & $\begin{array}{r}99.509 \\
2.566\end{array}$ \\
\hline
\end{tabular}

$a$ Wittstein, G. C., Untersuchungen einiger weissen Marmorarten, 1851.

It will be noticed that the calcite marbles in all the analyses show a range of 99.04 to 100 per cent of calcium carbonate.

A composite analysis by H. N. Stokes of 498 constructional limestones is given for comparison. The principal difference is in its high percentage of silica (14.09) and its small percentage of calcium carbonate (72.50).

\footnotetext{
1 Vogt, J. H. L., Norsk Marmor, 1897, p. 19.

2 Rosenbusch, H., Elemente der Gesteinslehre, 3d ed., 1910, p. 521.

3 Giampaoli, A., I marmi di Carrara, Pisa, 1897.
} 
Composite analysis of 498 constructional limestones. ${ }^{1}$

Silica $\left(\mathrm{SiO}_{2}\right)$

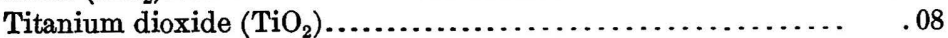

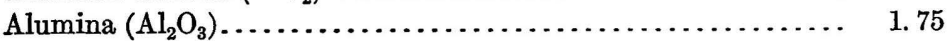

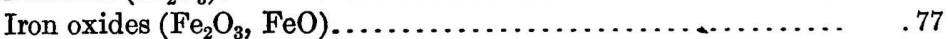

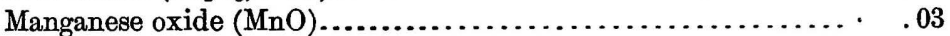

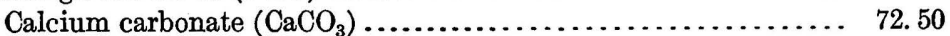

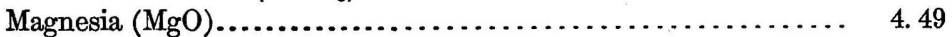

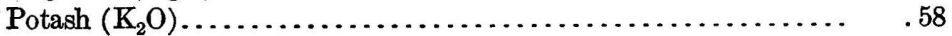

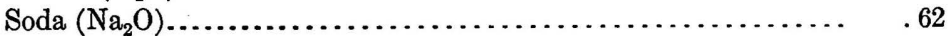

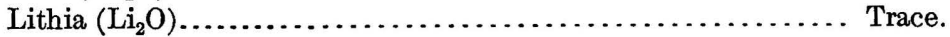

Water combined $\left(\mathrm{H}_{2} \mathrm{O}\right) \ldots \ldots \ldots \ldots \ldots \ldots \ldots \ldots \ldots \ldots \ldots \ldots \ldots \ldots \ldots \ldots \ldots \ldots \ldots, \quad .30$

Water uncombined and organic matter..................... $\quad 88$

Phosphorus oxide $\left(\mathrm{P}_{2} \mathrm{O}_{5}\right) \ldots \ldots \ldots \ldots \ldots \ldots \ldots \ldots \ldots \ldots \ldots \ldots \ldots \ldots \ldots \ldots \ldots \ldots, \quad .42$

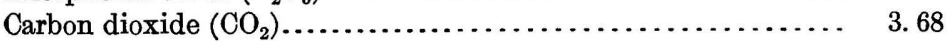

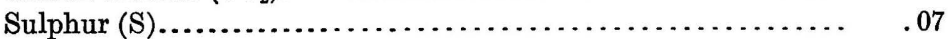

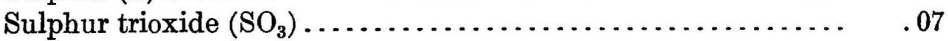

Chlorine $(\mathrm{Cl}) \ldots \ldots \ldots \ldots \ldots \ldots \ldots \ldots \ldots \ldots \ldots \ldots \ldots \ldots \ldots \ldots \ldots \ldots \ldots \ldots, .01$

100.34

The dolomite marbles in the analyses show a range of 30.27 to 30.88 per cent of lime and of 21.42 to 21.87 of magnesia, but a pure dolomite contains 30.4 per cent of lime and 21.9 of magnesia. ${ }^{2}$

Dieulafait ${ }^{3}$ determined the presence of diffused manganese in the marbles of Carrara, Paros, and the Pyrenees. Many of the exceedingly minute black particles present in all the white marbles examined by the writer may be an oxide of manganese. Two analyses of rosecolored calcite marble from eastern Vermont made by George Steiger, of the Survey, for another bulletin by the writer show 0.23 and 0.49 per cent of manganese oxide.

Lepsius ${ }^{4}$ notes that several of the Greek marbles (Paros, Naxos, Pentelicon, Hymettos, etc.) yield a marked bituminous odor when struck, which he attributes to the presence of a small amount of hydrocarbon.

Egenter ${ }^{5}$ calls attention to the odor of the contact-metamorphic marble of Carinthia, in Austria, which he attributes to sulphureted hydrogen.

Lindenmann ${ }^{6}$ reports that the Bardiglio marble of Carrara and the marble of Sterzing, in the Tyrol, both emit a very strong odor when struck.

1 Clarke, F. W., The data of geochemistry, 2d ed.: Bull. U. S. Geol. Survey No. 491, 1911, p. 533, analysis $\mathrm{H}$. In copying the analysis part of the $\mathrm{CO}_{\mathrm{g}}$ of the original has been combined with the $\mathrm{CaO}$ to show the percentage of $\mathrm{CaCO}_{8}$.

2 Clarke, F. W., op. cit., p. 544, analysis F.

3 Existence du manganèse à l'état de diffusion complète dans les marbres bleus de Carrare, de Paros et des. Pyrénées: Compt. Rend., vol. 98, 1884, pp. 589-591.

4 Lepsius, G. R., Griechische Marmorstudien: Anhang Abhandl. K. Akad. Wiss. Berlin, 1890.

5 Egenter, Paul, Die Marmorlagerstätten Kärntens: Zeitschr. prakt. Geologie, vol. 17, 1909, pp. 419-439

6 Lindenmann, Bernhard, Ueber einige wichtige Vorkommnisse von körnigen Carbonatgesteinen mit besonderer Berücksichtigung ihrer Entstehung und Structur: Neues Jahrb., Beilage Band 19, 1904, pp. 197-317. 
Further chemical details as to the marbles will be given in the descriptions of the different marbles.

\section{PHYSICAL PROPERTIES.}

Marble; besides possessing the qualities of hardness, cohesiveness, compressive strength, porosity, expansiveness under heat, thermal conductivity, sonorousness, translucence, and flexibility, is polishable and can be deformed in confinement under powerful compression. Its color, texture, specific gravity, hardness, and porosity will be considered under other heads.

Tests made at the Watertown Arsenal give the white dolomite marble of Lee, Mass., an ultimate compressive strength of 18,047 pounds to the square inch; ${ }^{1}$ the calcite marbles of West Rutland and Proctor a compressive strength of 11,525 to 14,397 pounds to the square inch $;^{2}$ and the coarse calcite marbles of South Dorset an ultimate compressive strength averaging 11,300 pounds when placed on bed and 9,100 pounds when placed on edge.

Tests of the dolomite marble of Lee give it a shearing strength of 2,052 pounds to the square inch and a maximum fiber strength of 1,585 pounds to the square inch. ${ }^{1}$

Vogt ${ }^{3}$ gives the compressive strength of a Norwegian dolomite marble as 24,891 to the square inch, of Carrara marble as 6,329 pounds, and of Tyrolese statuary marble (Laas) as 16,036 pounds.

Geikie ${ }^{4}$ in an interesting petrographic study of Edinburgh gravestones describes some slabs of white marble, presumably from Italy, firmly set into sandstone monuments, which in consequence either of their porousness and the freezing of interstitial water or else of their greater expansiveness than sandstone, or from both causes, had bulged out $2 \frac{1}{2}$ inches from their original vertical position and showed a series of rents along the crest of the bulge.

The Watertown Arsenal tests referred to above give the coefficient of expansion of dolomite marble from Lee as only 0.00000562 under a difference of temperature of $156^{\circ} \mathrm{F}$. Bartlett ${ }^{5}$ found the expansion of marble to be 0.000005668 inch to the foot for each degree Fahrenheit.

\footnotetext{
1 Twentieth Ann. Rept. U. S. Geol. Survey, pt. 6, continued, 1899, pp. 405, 406.

2 Tests Nos. 9059, 9060, 9063, made for the Vermont Marble Co., April, 1893, at the Watertown Arsenal. See p. 121.

${ }^{3}$ Vogt, J. H. L., Norsk Marmor: Norges geologiske Undersøgelse, No. 22, Christiania, 1897, p. 355.

4 Geikie, Archibald, Rock weathering as illustrated in Edinburgh churchyards: Proc. Roy. Soc. Edin. burgh, vol. 10, 1880, pp. 518-532; fig. 1, Thin sections of fresh and weathered marble after 87 years exposure; Pl. XVI, $A$, Bowed marble slab in frame of sandstone; $B$, Marble slab, cracked diagonally, in frame of sandstone. See also Geikie's Geological sketches at home and abroad, London, 1882, Chapter VIII, Rock weathering measured by the decay of tombstones, pp. 162-174.

5 Bartlett, W. C., Experiments on the expansion and contraction of building stones by variation of temperature: Am. Jour. Sci., 1st ser., vol. 22, 1832, pp. 136-140.
} 
Yamagawa ${ }^{1}$ determined the thermal conductivity of marble as averaging 0.00728 centimeter a second. A previous determination by Depretz was 0.0077 centimeter.

Thin slabs of ordinary Carrara marble have a marked sonorousness when struck with a hammer: The Vermont calcite marbles are only feebly sonorous, but on the other hand the dolomite marbles of Lake Champlain possess more sonorousness than the Carrara marble.

White marbles become transparent or nearly so in thin sections prepared for the microscope, but differ considerably in translucence on the rough or polished face. Some have a waxy look, which is probably attributable to the greater transparence of their grains; others are milk-white and opaque. Lepsius ${ }^{2}$ in connection with his study of Greek marbles determined that the best Pentelicon marble admits light to a depth of 0.59 inch, and the Parian to 1.37 inches. Upon this feature largely rested the reputation of Parian marble. Lindenmann ${ }^{3}$ gives the translucence of Carrara statuary marble as from 1.18 to 1.57 inches. The coarse calcite marble formerly quarried at Adams, Mass., referred to on page 54, is unusually translucent.

The flexibility of marble has long been known. It probably depends largely on the shape and cohesion of its grains. ${ }^{4}$

The important experiments of Adams, Nicholson, and Coker ₹ show that marble when tightly inclosed can be deformed-that is, it flows. They fitted cylinders of Carrara and Vermont marble tightly into steel tubes and applied great pressure to the ends of the cylinders, which caused them to bulge out on the sides, distending the inclosing tube. When the deformed marble was sliced and examined microscopically it was found to be solid, but many molecular changes had taken place in the individual crystalline plates, such as slippage and twinning. They also found that the marble if deformed at ordinary temperature was stronger under slow than under rapid deformation, that the deformed marble was stronger when the experiment was tried at a higher temperature than at ordinary temperature, and that when deformed in the presence of moisture (water gas) and a high temperature the deformed marble was actually stronger than

\footnotetext{
1 Yamagawa, Kenjiro, Determination of the thermal conductivity of marble: Jour. Coll. Sci., Imp. Univ. Japan, vol. 2, 1888. Review in Neues Jahrb., 1892, vol. 2, p. 43.

2 Lepsius, G. R., Griechische Marmorstudien: Anhang Abhandl. K. Akad. Wiss. Berlin, 1890, p. 47.

3 Lindenmann, Bernhard, Ueber einige wichtige Vorkommnisse von körnigen Carbonatgesteinen mit besonderer Berücksichtigung ihrer Entstehung und Structur: Neues Jahrb., Beilage Band 19, 1904, p. 273.

4 See Dewey, Chester, Notice of the flexible or elastic marble of Berkshire County: Am. Jour. Sci., 1st ser., vol. 9, 1825, p. 241. Julien, A. A., The durability of building stones: Tenth Census, vol. 10, 1884 (on the flexibility of marble, pp. 366,367 ; describes the curvature of a marble slab in the Alhambra). Winslow, A., An illustration of the flexibility of limestone [white crystalline]: Am. Jour. Sci., 3d ser., vol. 43, 1892, pp. 133, 134 .

${ }^{5}$ Adams, F. D., assisted by Coker, E. G., An experimental investigation into the flow of rocks-The flow of marble: Am. Jour. Sci., 4th ser., vol. 29, 1910, pp. 465-487; Pl. III, A, Thin section of Carrara marble magnified 40 diameters; $B$, The same caused to flow under pressure of 296 to 725 pounds to the square inch, showing schistosity, magnified 60 diameters. See Mr. Adams's other papers in bibliography, p. 55.
} $49311^{\circ}-$ Bull. 521-12-2 
the original marble. These experiments are very instructive, for they throw light on the causes of the remarkable folds in the marble beds of Vermont and similar regions and the conditions under which they were formed.

\section{GENERAL TEXTURE.}

The difference between a limestone and a marble has been stated (p. 11). In marble the grains are all crystalline, with rhombohedral cleavage, mostly twinned, and more or less interlocked but never in such an intricate way as they are in granite. To this fact and the marked cleavage of calcite and dolomite the generally lower cohesiveness of marble than of granite is largely due. Hirschwald ${ }^{1}$ figures two kinds of grain form in calcite marble - the denticulate and the smooth-and this distinction appears to be generally valid, although the grains in most of the Vermont calcite marble are not denticulate. In some dolomite marbles the grains do not interlock and some of the grains even have a rhombohedral form so that the texture under the microscope appears less cohesive than that of the other marbles. In both calcite and dolomite marbles the cleavage and twinning of each grain is independent of that of other grains.

Although the form of their grains is generally irregular, in some marbles one or two axes of the grains are much longer than the others and the longer axes of different grains are parallel, giving to the rock a certain schistosity which is usually parallel to the bedding. (See figs. 6, 22.) A thin section of such a marble from the St. Gotthard is figured by Rosenbusch. ${ }^{2}$ This elongation, however, may be confined to but a part of the grains and these may not be arranged. A marble at Leicester Junction (p. 147 and fig. 25) exhibits alternate tiers of large and small grains. As the marble is intensely folded this arrangement may be due to granulation or it may be the result of the interbedding of dolomite and calcite, the smaller grains being dolomite.

Lepsius ${ }^{3}$ in his study of Greek marbles found that those of Pentelicon, Hymettos, and the vicinity of Cape Sunium and of Doliana, in Arcadia, consist of irregularly bounded grains of twinned calcite, lying in a matrix of much more minute calcite grains without cleavage or twinning planes, and that the proportionate amount of the matrix varies in different beds and localities. $\mathrm{He}$, regards the matrix in these marbles as a remnant of the limestone out of which the twinned grains were formed under metamorphism.

\footnotetext{
1 Hirschwald, J., Die Prüfung der natürlichen Bausteine auf ihre Wetterbeständigkeit, Berlin, 1908, Pl. XVI, figs. $1,2$.

2 Rosenbusch, H., Elemente der Gesteinslehre, 3d ed., 1910, fig. 78.

¿Lepsius, G. R., Griechische Marmorstudien: Anhang Abhandl. K. Akad. Wịș, Bẹrlin, 1890.
} 
Vogt ${ }^{1}$ figures a Norwegian marble in which interlocking grains of calcite alternate irregularly with angular ones of dolomite.

In some Vermont marbles minute beds and lenses of dolomite are intercalated in the calcite mass and other interesting combinations of calcite and dolomite occur. (See p. 131, fig. 20.) Vogt ${ }^{2}$ figures a marble in which the calcite plates, owing to secondary compression, due to contact metamorphism, have suffered granulation and had their twinning planes bent. Hirschwald ${ }^{3}$ also figures thin sections of marble with bent twinning planes. One of the marble beds of West Rutland shows this also.

A thin section of calcite marble with flexed twinning planes is shown in figure 1 .

In a brecciated marble each fragment has its texture more or less differently oriented and the texture of the fragment differs from that of the secondary cement. The same is also true of the pebbles in a marble conglomerate, except that more or less parallelism in the texture of the smaller pebbles may be expected.

There is also a variation in the grade of texture. The grains may

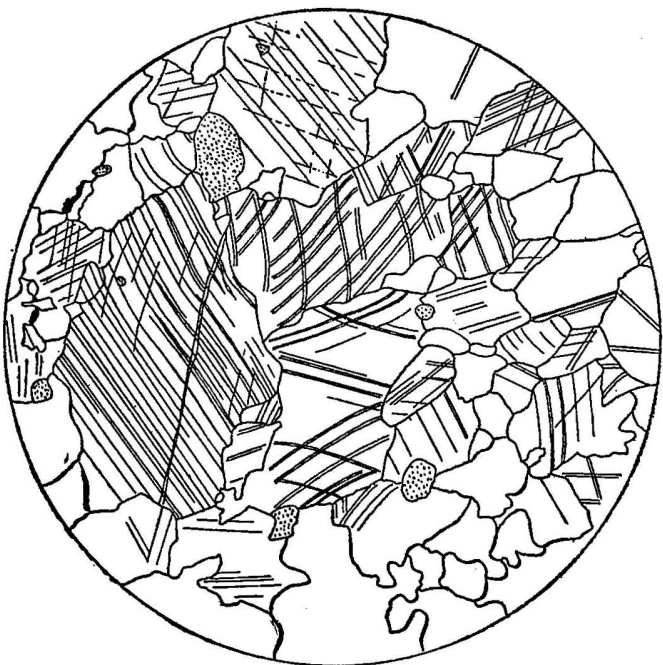

Figure 1.-Thin section of white calcite marble from the Goodale or Girard College quarry in Sheffield, Mass., with flexed twinning planes due to secondary compression. Texture very coarse and irregular. Dotted particles are quartz. Enlarged 20 diameters. This quarry supplied columns for Girard College, in Philadelphia. The curvature of the calcite plates can be detected, even in a hand specimen. be large, medium, or small and a further variation may be traceable to the regularity or irregularity in the size of the grains in the same marble.

The presence of sericite (fibrous potash mica), tremolite, actinolite (varieties of hornblende), or other fibrous minerals complicates the texture of marble. (See pp. 41, 43.)

The texture is indirectly affected by the character of the bedding, which may be even or plicated or elongated. This is more apparent in the graphitic and micaceous marbles. In some Vermont marbles

1 Vogt, J. H. L., Der Marmor in Bezug auf seine Geologie, Structur und seine mechanische Eigenschaften: Zeitschr. prakt. Geologie, January, 1898, p. 14, fig. 10.

2 Op. cit., p. 14, fig. 12; also Norsk Marmor, 1897, p. 59, fig. 8.

${ }^{3}$ Hirschwald, J., Die Prlifung der natïrlichen Bausteine auf ihre Wetterbeständigkeit, Berlin, 1908, PI. XVI, figs. 4,5 . 
sharply plicated planes of bedding are intersected at intervals by slightly undulating planes of slip cleavage and both sets of planes are laden with graphite. (See p. 124 and Pls. V, $A$, and VIII, $B, b$.)

The texture of marble thus depends on the form, size, evenness, and arrangement of its grains and on the nature and size of the grains of other minerals in it and is affected by the amount of plication or elongation of the bedding, by the relative abundance of the planes of slip cleavage which cross it, and by any secondary compression that the marble may have suffered.

\section{COLORS.}

It would require very elaborate methods to determine the precise causes of the more delicate tints of marble, such as the bluish, ivory, and smoky. The causes of other tints are not far to seek.

The black and grayish marbles owe their shade to the presence of carbon, usually in the form of graphite in infinitesimal scales and powdery particles disseminated throughout the plates of calcite or dolomite.

The reddish, pinkish, and reddish-brown marbles contain minute particles of a compound with manganese oxide $(\mathrm{MnO})$ or of hematite $\left(\mathrm{Fe}_{2} \mathrm{O}_{3}\right)$ or of both.

The brownish, yellowish, and cream-colored marbles owe their color to limonite or hydrous iron sesquioxide (ferric oxide) $\left(2 \mathrm{Fe}_{2} \mathrm{O}_{3} \cdot 3 \mathrm{H}_{2} \mathrm{O}\right)$ in varying amounts. In thin sections of some marbles this limonite stain can be seen emanating from oxidized particles and crystals of pyrite.

The greenish marbles (of course exclusive of the serpentines), of Vermont at least, owe their color mainly to fibrous muscovite (sericite), with which in the brighter marbles chlorite and epidote are associated.

A purplish tint in one of the dolomites of Lake Champlain (p. 143) appears to be due to the combination of hematite and magnetite.

The more uncommon colors of marble are purplish, as in the Pavonazzo and Seravezza breccias, imported from Italy, bright yellow, as in the "Giallo Antico" from North Africa, and orangeyellow, as in some marbles from Norway. Among the uncommon combinations of colors is that of rose-pink and deep green in the "Leifset Gloire" from Norway.

Vogt ${ }^{1}$ is inclined to attribute the sky-blue, bright-red, and orange tints of some Norwegian marbles to organic compounds. He states that the blue disappears on heating for a short time to $100^{\circ} \mathrm{C}$., or after five years exposure to the light, and that the red changes after heating for a short time to $300^{\circ}$ or for a longer time to $150^{\circ}$ to $200^{\circ}$ but returns on cooling. 


\section{ORIGIN OF IIMESTONE AND MARBLE.}

The origin of marble can not well be considered without considering that of the limestone from which it has been formed. The origin of dolomite marble will be considered after describing the relations of dolomite and calcite marble.

Some of the simplest illustrations of the formation of calcareous deposits are to be found at no great distance from the Vermont marble belt. About 4 miles nearly north of Fair Haven, in Rutland County, Vt. (see topographic map of Whitehall quadrangle, U. S. Geol. Survey), is Inman Pond, which is about half a mile long. When the pond is low a snow-white calcareous deposit, which consists mainly of fragments of fresh-water snail shells (Limnæa and Planorbis), is exposed on the shore. The pond is surrounded by hillocks of slightly calcareous slate and the glacial gravels probably contain some limestone from the limestone areas to the north and west. The brooks, supplied with carbonic acid by the rain, have taken up calcium carbonate from the slates and the gravel and furnished the pond with slightly calcareous water, which the snails have taken into their systems and out of which they have secreted shells of calcium carbonate. The death of generations of snails has formed the white marl.

Queechy Lake, also half a mile long, lies in a minor limestone valley within the Taconic Range in Canaan, Columbia County, N. Y. (See topographic map of Pittsfield quadrangle, U. S. Geol. Survey.) The bottom of the east side of the lake is covered with certain foliaceous algæ, the leaves of which are incrusted with calcium carbonate. As generations of these plants die a calcareous sediment forms. It is supposed that the chemical precipitation of lime by water in such a case is accelerated by the exhalation of oxygen by the plants and the consequent decomposition of the calcium bicarbonate.

As most limestones are seen by the character of their fossils to be of marine origin, we must consider processes like those illustrated to have taken place in the sea-that is, calcium carbonate has been either deposited through the agency of life or chemically precipitated. An ordinary limestone would result from any great accumulation of such organic or chemical calcareous sediments compressed under their own weight. The formation of organic calcareous sediments is going on to-day in the ocean on a large scale about coral reefs and shell beds and wherever the minute calcareous shells of rhizopods rain down on the ocean floor, also wherever lime-secreting algæ abound.

Two places are cited, one in the Mediterranean and another on the west coast of Florida, where river water charged with calcium 
bicarbonate forms crystalline calcareous sediments as it enters the sea. The Florida deposit is of two sorts-a calcareous mud and a crystalline calcium carbonate that is essentially a calcite marble. ${ }^{1}$ But it is generally assumed by geologists that such deposits are exceptional, that most limestones have been formed through the medium of marine organisms, and that those limestones which abound in fossil crinoids, corals, brachiopods, gastropods, or rhizopods convey to us what is probably the most correct conception not only of the origin of limestone but also of the original condition of most calcite marbles.

Some fossiliferous limestones that have not been subjected to a crustal movement great enough to destroy the outline of their fossils are yet crystalline and therefore marble. It may be uncertain

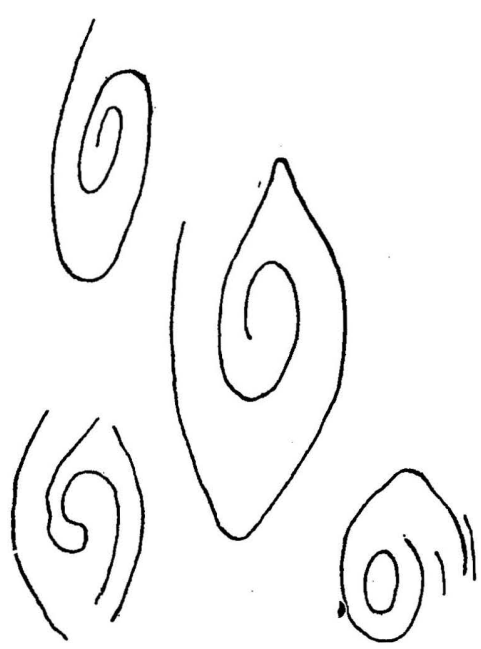

FIGURE 2.-Sections of marine snail shells in light marble on dumps at West Rutland in 1890. A little less than one-half natural size. whether the crystallization of such limestones took place before or after their emergence. In either case where the fossils have become crystalline we have to assume the percolation of acid waters dissolving the calcareous shells, etc., and then redepositing the lime thus taken up as crystalline calcite. This process has taken place in the black and gray marbles of Isle la Motte (see p. 47) and in all the crinoid or shell marbles of commerce, such as the Tennessee marbles.

That the calcite marbles of western Vermont were partly if not wholly of organic origin is shown by the fossils they still contain. One of the beds of bluish-gray marble at West Rutland abounds in sections of Maclureas (large marine snails), as may be seen by examining the slabs coming from the sawing sheds. A photograph of one of these slabs polished, taken by the State geologist, has been reproduced in one of his reports. ${ }^{2}$ Figure 2 is taken from drawings made by the: writer. Some of the grayish marble beds above the quarries at West Rutland are very fossiliferous, as is a ledge beside a brook about one-fourth mile south of the Eastman quarry. (See Pl. IV.) The bluish marble at Day's quarry, in Ira, long worked for lime, contains sections of large gastropods, probably

\footnotetext{
I Lyell, Charles, Principles of geology, 9th ed., 1853, pp. 260, 279. Dall, W. H., and Harris, G. D., Correlation papers-Neocene: Bull.U. S. Geol. Survey No. 84, 1892, pp. 99-101, 154. Willis, Bailey, Conditions of sedimentary deposition: Jour. Geology, vol. 1, 1899, pp. 512-514.

2 Perkins, G. H., Report of the State geologist on the mineral industries and geology of certain areas of Vermont: Report for 1907-1908, Pl. V.
} 
Maclureas also. ${ }^{1}$ Most of the Vermont calcite marbles, however, have no traces of fossils.

It is assumed that the general absence of fossil forms from calcite marble is due to their having been obliterated in the process of dynamic crystallization. This process has been reproduced experimentally, uncrystalline calcium carbonate having been changed to calcite marble by pressure alone, heat alone, or both together. ${ }^{2}$

The simplest of all these experiments consisted in exposing limestone and chalk in a closed gun barrel to great heat, ${ }^{3}$ which resulted, in transforming them into marble.

That the horizontal massive strata which now constitute the marble beds of western Vermont were subjected to very great compression is evident from the folding they have undergone. This is shown in the general and detailed sections (Pls. II and III; figs. 10, 11, 14, and 18 , pp. 78, 79, 103, and 125). Such folding can be produced only by powerful lateral compression, and such compression would generate heat. Furthermore, the micaceous marbles that are interbedded with the others and the small beds of mica schist that are interbedded with the clear marbles owe their fibrous mica to the micasization of particles of clayey sediment, and the process of micasization, as reproduced experimentally, has been found to require heat as well as pressure. ${ }^{4}$

For these reasons the calcite marbles of western Vermont and of regions of like geologic character are regarded as limestones of marine and mostly of organic origin, which have been metamorphosed under great pressure accompanied by heat.

In view of what has been stated as to the origin of limestone and calcite marble we should distinguish between (a) a fine-grained limestone in which the particles are exceedingly minute and of irregular form and polarize but are without twinning planes; $(b)$ a fossiliferous limestone in which percolating waters have dissolved calcareous fossils and deposited crystalline calcite; and $(c)$ a fully crystalline calcite marble, the product of metamorphism, in which the calcite plates, larger than those in the matrix of $b$, are mostly twinned. Hirschwald, ${ }^{5}$ in his exhaustive work on the testing of the weathering qualities of building stones, divides the finer-grained limestones

\footnotetext{
1 Letter from C. D. Walcott.

2 See Clarke, F. W., The data of geochemistry, 2d ed.: Bull. U. S. Geol. Survey No. 491, 1911, pp. 531, 532. 3 See Hall, James, Trans. Royal Soc. Edinburgh, vol. 6, 1812, pp. 71-185; Becker, Arthur, Min. pet. Mitt., vol. 7, 1886, pp. 122-145; and Le Chatelier, H., Compt. Rend., vol. 115, 1892, pp. 817-820, 1009-1011.

${ }^{4}$ A. Daubrée (Études synthétiques de géologie expérimentale, 1879, pp. 176, 177; Smithsonian Rept. 1861 , p. 285), by exposing moist clay in a closed steel tube to the heat of a gas furnace for several days, succeeded in manufacturing minute crystals of a uniaxial mica or a chlorite. On the subject of micasization or sericitization see Clarke, F. W., The data of geochemistry, 2d ed.: Bull. U. S. Geol. Survey No. 491, 1911, pp. 566-568.

${ }^{5}$ Hirschwald, J., Die Prüfung der natürlichen Bausteine auf ihre Wetterbeständigkeit Berlin, 1908, p. 382 .
} 
(excluding marbles) into two groups-cryptocrystalline, in which the interlocking ill-defined crystalloids polarize light, and pelitomorphic, which consist of roundish granules 0.003 to 0.005 millimeter in diameter, that feebly but clearly operate upon polarized light. ${ }^{1}$

The metamorphism by which a bed of limestone is changed to marble is not always traceable entirely to lateral compression of the strata. It may also be caused in part by the heat proceeding from an igneous intrusive.

Renwick ${ }^{2}$ mentions an interesting occurrence at Middleton, near Wirksworth, in Derbyshire, where beds of limestone have been traversed by a dike at a very low angle. The limestone below the dike has been changed to marble, and is quarried for marble uses, but the limestone above the dike is unaltered and is used for lime burning, etc.

Conybeare ${ }^{3}$ described the conversion of chalk into marble in the north of Ireland, in these words: "Here within the distance of 90 feet three [basalt] dikes may be seen traversing the chalk, which is converted into a finely granular marble where contiguous to the two outer dikes and through the whole of the masses included between these and the central one."

Finally, the metamorphism by which a bed of limestone passes into marble may be of any geologic age. Naturally we look for marbles in the strata formed after marine life became abundant and in those places where organic deposits have been subjected to powerful crustal movements or exposed to igneous intrusion.

\section{CALCITE MARBLE.}

If calcite marble contained nothing but calcite its chemical composition and properties and many of its physical properties would be identical with those of calcite. Calcite $\left(\mathrm{CaCO}_{3}\right)$, or calcium carbonate, contains 56 per cent of $\mathrm{CaO}$ (lime) and 44 per cent of $\mathrm{CO}_{2}$ (carbon dioxide). It effervesces strongly with cold dilute hydrochloric acid and is entirely soluble in cold dilute acetic acid. When burned it loses $\mathrm{CO}_{2}$ and becomes $\mathrm{CaO}$ (quicklime). It has a specific gravity of 2.72 and a hardness of 3 , being a little harder than gypsum, which is 2 , and softer than dolomite, which is 3.5 to 4 . It has a marked rhombohedral cleavage and a white or grayish streak when scratched.

Calcite marble when perfectly pure and therefore white consists entirely of crystalline plates of calcite with rhombohedral cleavage,

\footnotetext{
1 Hirschwald, J., Die Prüfung der natürlichen Bausteine auf ihre Wetterbeständigkeit, Berlin, 1908, pp. 443, 444; sec. 532; Pl. XVII, figs. 10, 11, 12.

2 Renwick, W. G., Marble and marble working, London, 1909, p. 4, fig. 1.

a Conybeare, W. [Descriptive notes referring to the outline of sections presented by a part of the coasts of Antrim and Derby, from the joint observations of Rev. W. Buckland and himself during a tour in the summer of 1813]: Trans. Geol. Soc. London, vol. 3, 1816, p. 210.
} 


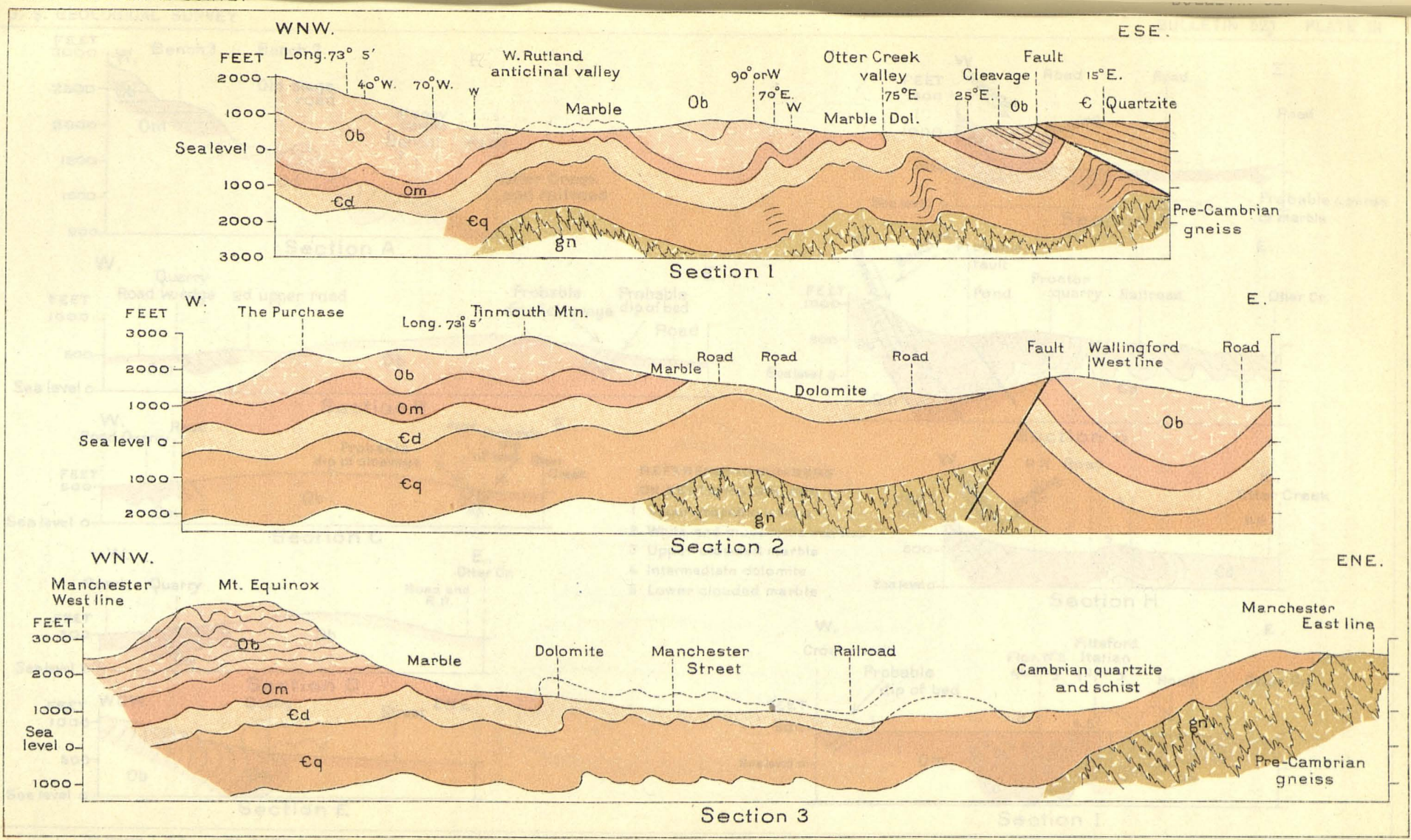

\section{GENERAL SECTIONS ACROSS THE MARBLE BELTS OF WESTERN VERMONT}

Showing their probable approximate structural relations

$1 \quad 0 \quad$ Scale $\frac{1}{62.500}+1 \quad 2$ Miles

Lines of sections and explanation of formations given on Plate I 



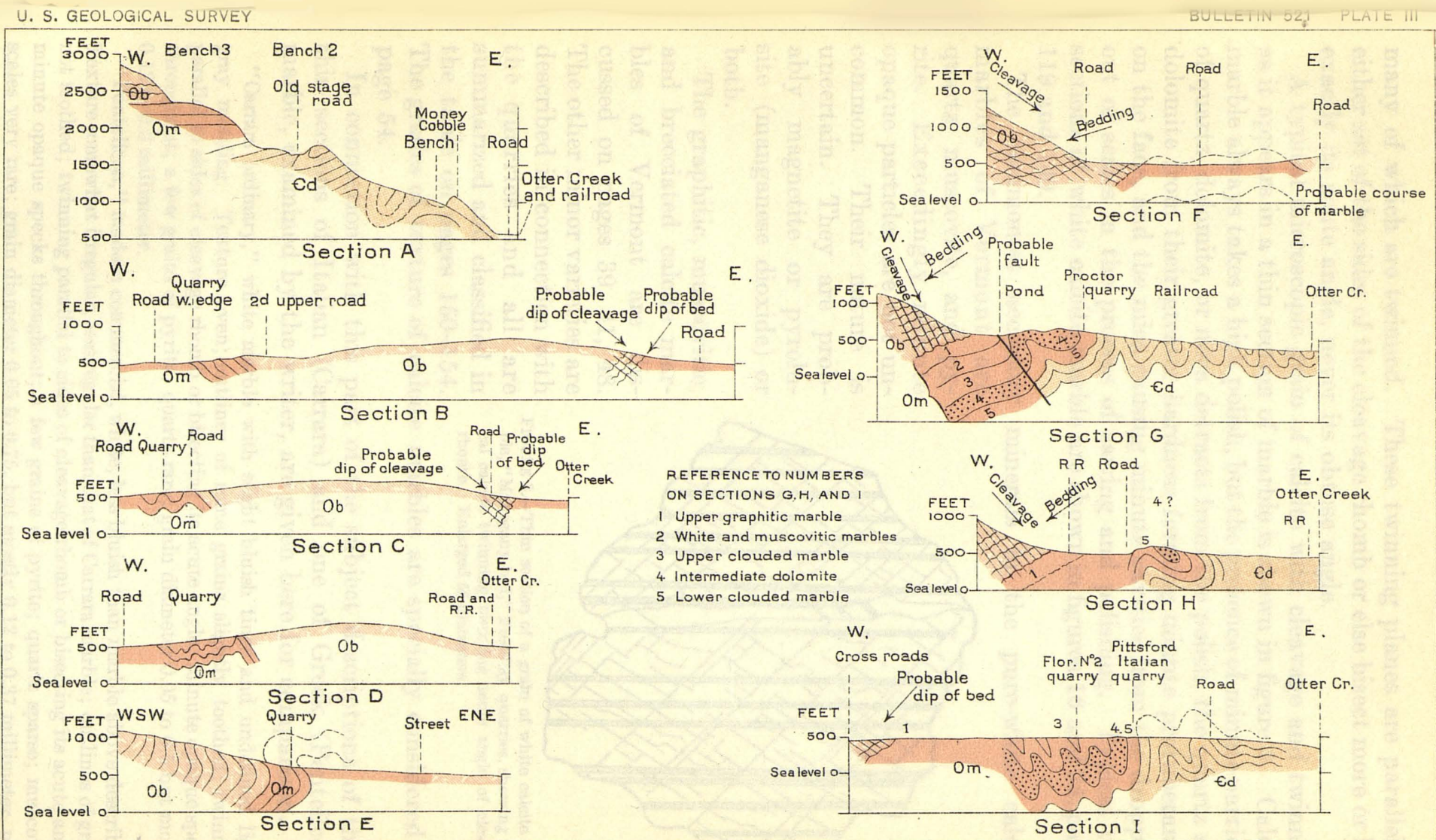

\section{DETAIL SECTIONS OF PORTIONS OF THE MARBLE BELTS OF WESTERN VERMONT}

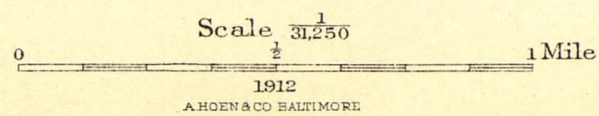

Lines of sections and explanation of formations given on Plates I and IV 

many of which are twinned. These twinning planes are parallel to either set of the sides of the cleavage rhomb or else bisect more or less exactly its acute angle, never its obtuse angle.

A typical microscopic grain of calcite with cleavage and twinning as it appears in a thin section of marble is shown in figure 3. Calcite .marble always takes a high polish, but the presence of minute particles of quartz, dolomite, or mica detracts from the polish, the quartz and dolomite from their greater hardness forming minute protuberances on the face, and the mica causing minute cavities from the dropping out of scales in the process of sawing and polishing. Typical thin sections of white calcite marble are shown in figures 16 and 24, pages 119 and 140.

The commonest accessory minerals in the pure-white calcite marbles of Vermont are quartz, muscovite, and pyrite. Exceedingly minute opaque particles are not uncommon. Their nature is uncertain. They are probably magnetite or pyrolusite (manganese dioxide) or both.

The graphitic, muscovitic, and brecciated calcite marbles of Vermont are discussed on pages $39,41,48$. The other minor varieties are described in connection with the quarries and all are summarized and classified in the table on pages $150-154$.

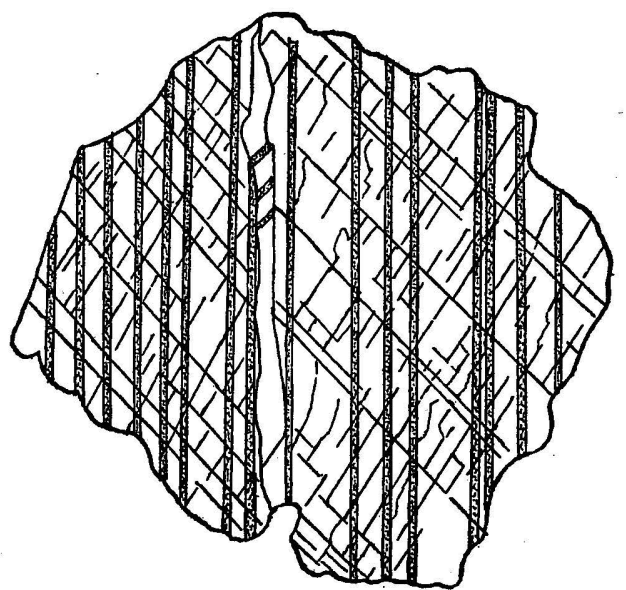

FIGURE 3.-Thin section of a grain of white calcite marble, "Mahogany bed," Freedley quarries, showing typical calcite twinning bisecting acute angle of cleavage rhomb. Enlarged 55 diameters.

The grades of texture of calcite marbles are specially considered on page 54 .

In connection with this part of the subject descriptions of three thin sections of Italian (Carrara) and one of Greek (Pentelicon) marble, examined by the writer, are given here for comparison.

"Carrara ordinary," white marble with slight bluish tinge and undefined lightgray mottling. Texture even; outlines of some grains slightly toothed; twinning parallel to sides of cleavage rhomb or bisecting its acute angle; minute opaque specks throughout; a few grains of pyrite; quartz rare; grain diameter 0.05 to 0.5 but mostly 0.12 to 0.3 millimeter.

"Pentelicon," modern commercial, white, less bluish than marble above described. Texture somewhat irregular, less regular than that of Carrara marble; outlines of grains not toothed; twinning parallel to sides of cleavage rhomb or bisecting its acute angle; minute opaque specks throughout; a few grains of pyrite; quartz sparse; muscovite scales very rare; grain diameter 0.05 to 0.75 , but mostly 0.12 to 0.37 millimeter, more of 0.12 than in Carrara marble. 
The interesting study of Greek marbles by Lepsius ${ }^{1}$ already referred to (p. 18) was based on the examination of thin sections obtained from outcrops at the chief quarries worked by the ancient Greeks, at some of which unfinished columns or statues still remained, and on a comparison of such sections with others obtained from chips of similar marbles in ancient Greek buildings and sculptures. These quarries were on the islands of Paros and Naxos, in the archipelago; on Mounts Pentelicon and Hymettos, about northeast of Athens; in the Agrilesa Valley, $2 \frac{1}{2}$ miles north of Cape Sunium and 25 miles southeast of Athens; and at Doliana, in Arcadia, southwest of Corinth. As Lepsius's book is one of the most thorough works on the texture of marble yet published but is inaccessible in translation, a brief summary of its conclusions is here given:

"Lichnites Lithos" of Paros, "Parian statuary," from the northwest side of the island, was obtained from a bed $6 \frac{1}{2}$ to 13 feet thick with an average dip of $30^{\circ}$ into the hill, reached by tunneling from a point 656 feet above sea level along the bed to a depth of 195 to 260 feet. From this excavation at least 1,000,000 cubic feet of marble, from which, of course, the waste should be deducted, had been excavated in ancient times for statuary. This marble is snow white, with a faint bluish-gray tint. It is very translucent and was also noted among Roman stonecutters for its hardnessthat is, its cohesion-which was probably due to its being quarried so far underground. It consists entirely of cleft and twinned calcite grains with diameter mostly of 1 to 1.5 millimeters, many grains 1.5 to 2 , some 2 to 3 , and a few 3 to 5 . It contains some grayish particles, mostly translucent, also some extremely minute black ones (magnetite or carbon?). In some parts of the quarry the marble has dark-gray streaks due chiefly to magnetite, as determined by the form of the crystals. ${ }^{2}$

The Naxos marble beds dip $25^{\circ}$ to $70^{\circ}$, but were quarried diagonally. The marble has a light-gray tint with dark-gray spots and streaks and some gray grains. It is opaque and coarse, with an average grain diameter of 2 to 3 millimeters and many grains 3 to 5 millimeters, here and there with some fine interstitial grains. Many of the grains contain minute gray, black, or colored particles to which the marble owes its tint. In places the dark particles are so plentiful as to cloud the otherwise clear calcite. ${ }^{3}$

The "lower white Pentelicon marble" is somewhat milk white with a faint yellowish tint and rare light-gray streaks. The grain diameter is mostly 0.5 to 1 millimeter, never over 2 millimeters. The grains lie in an opaque milk-white groundmass of fine grains, without cleavage or twinning planes. Both large and small grains contain very minute and indeterminable inclusions. Muscovite, chlorite, a reddish-violet potash mica, pyrite with a zone of limonite, more rarely magnetite, and rare grains of quartz occur in it. The decay of parts of the great frieze of the Parthenon, which was cut from this marble, is due to the presence of mica streaks along the bedding plane. ${ }^{4}$ (See further, p. 37.)

"Hymettic marble," from the upper blue-gray beds of the northwest and north slopes of Mount Hymettos, consists of cleft and twinned calcite grains up to 0.5 or rarely 0.8 millimeter in diameter, thus smaller than in the Pentelicon marble, in a dense, slightly translucent groundmass of fine calcite grains without cleavage or twinning, the groundmass predominating over the larger calcite grains. The accessory

1 Lepsius, G. R., Griechische Marmorstudien: Anhang Abhandl. K. Akad. Wiss. Berlin, 1890.

2 Idem, pp. 43-52.

3 Idem, pp. 52-55.

4 Idem, pp. 15-22. 
minerals are muscovite, chlorite, and small black particles of iron, which rust on exposure. The gray shade is attributed to minute grains of carbon. ${ }^{1}$

The "lower white Attic marble" from the quarry near Cape Sunium has a light bluish-gray tint and gray banding. Its cleft and twinned larger calcite grains measure as much as 1 millimeter. The groundmass of smaller structureless grains is relatively small in amount. The marble does not form a yellowish crust in weathering. The minute black specks, visible in thin sections, are regarded as carbon. ${ }^{2}$ (See p. 15.)

The marble of Doliana, in Arcadia, is faintly bluish gray and without streaks. The cleft and twinned calcite grains are denticular and elongate, with diameters of $\mathbf{0 . 5}$ to 1 , rarely 2 to 4 millimeters, lying in a dense glassy light bluish-gray groundmass of minute structureless calcite grains. This marble contains 0.12 per cent of $\mathrm{Fe}_{2} \mathrm{O}_{3}$ and therefore in weathering forms a yellow and reddish brown film. In weathering the groundmass becomes milk white, the larger grains become more conspicuous, and the stone finally becomes "sandy." The thin sections show rare quartz grains and dark grains. $^{3}$

Interesting descriptions of other European marbles will be found in the papers of Vogt, Lindenmann, Weinschenk, and Steinhäuser, cited in the bibliography on pages 56, 58 .

Of the Tyrolese marbles less is known in this country than of the Italian. They occur near.Laas Peak, about 22 miles west-southwest of the city of Meran, in Vintschgau, in the Austrian Tyrol. They include a coarse marble with grain diameter of 5 millimeters (Sterzing) which takes a high polish, and also a finer marble, "Laas statuary," with a maximum grain diameter of 1 millimeter. The latter is quarried at a point 7,535 feet above the valley floor. It is clear white and very sonorous. It is almost as translucent as Carrara statuary marble, but is somewhat harder and coarser and has been found to be more durable under outdoor exposure in the climate of central Europe. It has been used for the statues of Mozart and Haydn in Vienna and Von Moltke in Berlin and is regarded as equal to Parian marble for statuary.

The purplish and white brecciated "pavonazzo" of Carrara contains a little micaceous hematite and some biotite. The "cipolino". of the same region has calcite grains with flexed twinning planes. It contains biotite passing into chlorite, epidote, klinozoisite, titanite, tourmaline, and green hornblende. The "bianco P" of Carrara has veinlets of untwinned dolomite.

\section{DOLOMITE MARBLE.}

A pure dolomite marble would have the chemical and many of the physical properties of dolomite. It has greater compressive strength than calcite marble, as is shown by the tests recorded on page 16 .

Dolomite $\left(\mathrm{CaMgC}_{2} \mathrm{O}_{6}\right)$, a carbonate of lime and magnesia, contains 54.35 per cent of $\mathrm{CaCO}_{3}$ (calcium carbonate) and 46.65 per cent of $\mathrm{MgCO}_{3}$ (magnesium carbonate). It effervesces less readily with cold

1 Lepsius, G. R., Griechische Marmorstudien: Anhang Abhandl. K. Akad. Wiss. Berlin, 1890, pp. 22-24.

2 Idem, p. 27.

3 Idem, pp. 31-33. 
dilute hydrochloric acid than calcite and is next to insoluble in cold dilute acetic acid. It burns like calcite. It has a specific gravity of 2.83 and a hardness of 3.5 to 4 , being thus a little heavier and harder than calcite. It has a marked rhombohedral cleavage and crystallizes in rhombohedra, the faces of which are usually curved.

Dolomite marble is of two kinds. One is like that of Lee, Mass., which consists of crystalline plates of dolomite of irregular outline, with rhombohedral cleavage and twinning planes that are either parallel to a side of the cleavage rhomb or bisect its obtuse angle, as in figure 4. Rarely it bisects the acute angle. In a section of dolomite from Plymouth, Vt., a grain was found in which twinning planes bisect both acute and obtuse angles. In calcite the twinning plane never bisects the obtuse angle, being either parallel to one of the sides of the rhomb or bisecting its acute angle. This distinc-

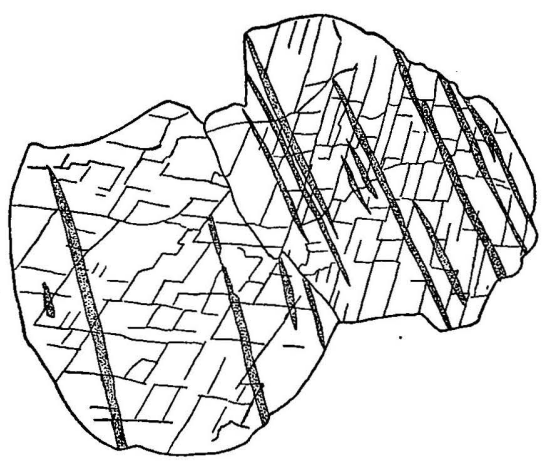

FIGURE 4.-Thin section of white twinned dolomite marble from Gross quarry, Lee, Mass., showing two grains of dolomite with typical dolomite twinning bisecting obtuse angle of cleavage rhomb. Enlarged 77 diameters. resembling that of loaf sugar, in which the grains simply cohere. In such a marble the cohesion is less than that of a calcite marble or of the dolomite marble of Lee, although the material is harder than calcite.

In the other variety of dolomite marble the texture is finer and more granular or mixed coarse and fine, and a larger or smaller percentage of the grains have a rhombic outline but are not twinned. (See fig. 8, p. 44.) Exceptionally, however, a lens or veinlet with twinned plates of dolomite occurs in these marbles. To this variety belong the marbles of Lake Champlain fully described beyond.

1 See Rosenbusch, H., Elemente der Gesteinslehre, 3d ed., 1910, p. 523; also Vogt, J. H. L., Der Marmor in Bezug auf seine Geologie, Structur, und seine mechanische Eigenschaften: Zeitschr. prakt. Geologie, Berlin, 1898, p. 11.

2 See Lemberg, J., Zur mikroskopischen Untersuchung von Calcit, Dolomit und Predazit: Zeitschr. Deutsch. geol. Gesell., vol. 40, 1888, pp. 357-359. 
Dolomite marbles of both kinds take a high polish but of course are harder to polish than calcite marble. Some dolomite marble becomes minutely pitted in polishing from the dropping out of powdery magnesia as a result of the decomposition of some of the dolomite grains.

The commoner accessory minerals of white dolomite marble are quartz, pyrite, muscovite, and tremolite.

The colored dolomite marbles of Vermont, containing hematite or graphite, are described on pages 43-46, and are summarized and classified in the table on pages 152-153. Their grades of texture are specially considered on pages 142-143.

Descriptions of a few thin sections of dolomite marble from Massachusetts, Connecticut, and Norway, studied by the writer, are added for reference and comparison.

White dolomite marble, Gross quarry, Lee, Mass. Pale bluish white without tremolite, which, however, abounds in certain beds. Texture, even; grain outlines but slightly toothed; twinning bisects obtuse angle of cleavage rhomb. (See fig. 4.) Grain diameter 0.07 to 1 , mostly 0.02 to 0.5 millimeter. ${ }^{1}$

Bluish dolomite marble, Ashley Falls Marble Co.'s quarry, Ashley Falls, Mass. Light bluish gray, rarely with prisms of tremolite and minute pyrite. Texture even; grain outlines somewhat toothed; twinning planes bisect obtuse angle of cleavage rhomb; minute opaque specks throughout; a few muscovite scales; quartz rare and small; no pyrite or tremolite in sections. Grain diameter 0.02 to 0.75 , mostly 0.05 to 0.5 , average 0.27 millimeter.

Light bluish gray, very fine grained dolomite (not commercial marble) from a drill core 35 feet below rock surface at Agricultural National Bank, Pittsfield, Mass. Texture uneven; grain outline roundish or angular, not rhombic and without twinning. Some muscovite scales; quartz and plagioclase feldspar grains; pyrite crystals. Diameter of grains 0.02 to 0.17 but mostly 0.05 to 0.12 , average 0.08 millimeter. Some lenses or veins of coarse particles abounding in minute opaque specks, diameter 0.12 to 1.25 millimeters, with twinning bisecting obtuse angle of cleavage rhomb.

White dolomite marble from near Amenia, N. Y., but in Connecticut. White to cream color, granular appearance. Texture even; grain outlines straight or roundish; twinning bisects obtuse angle of cleavage rhomb; one bisecting acute angle. (See p. 28.) Grain diameter 0.05 to 0.62 , mostly 0.12 to 0.25 , average 0.18 millimeter.

White dolomite marble from Norway. Milk-white with parallel grayish streaks. Texture very irregular; grain outlines not toothed; twinning planes parallel to sides of cleavage rhomb or bisecting its obtuse angles. Minute opaque specks throughout. Several large muscovite flakes; pyrite minute, sparse. In finer parts grain diameter 0.05 to 0.25 , average 0.15 millimeter; in coarser parts 0.12 to 1.37 , many 0.25 to 0.62 millimeter.

\section{RELATION OF CALCITE MARBLE TO DOLOMITE IN VERMONT.}

As will be seen from the geologic map (Pl. I) and the discussion of the geologic formations on page 64, the lower 650 feet, approximately, of the Vermont calcareous belt consist mainly of dolomite, described in detail on page 66 , and the marble is confined almost entirely to the

1 This marble has been described by J. S. Diller in Bull. U. S. Geol. Survey No. 150, 1898, pp. $299,300$. 
upper half of the formation. The most productive quarries appear to be in the upper part of this upper half, although some occur also in the lower part. But, as appears from the detailed sections and the stratigraphic succession on page 66 , the marble beds themselves are interbedded with dolomite.

At the now disused Sutherland Falls or Proctor quarry (see Pl. I) the calcite marble beds, roughly estimated at 170 feet thick but in part doubled over so as to measure apparently 200 feet, are overlain on the west by dolomite and also underlain on the east by another dolomite. The dolomite on the west side, which is followed farther west by calcite marble, consists of dolomite granules, rarely rhombs, having an average grain diameter of 0.04 millimeter and some dolomite plates reaching 0.25 millimeter, with twinning planes bisecting the obtuse angle; also sparse quartz grains, muscovite flakes, and pyrite oxidizing to limonite. The whitish dolomite on the east side consists of dolomite plates, some of them twinned, all crowded with dark granules, having diameters mostly 0.12 to 0.45 millimeter, lying in a matrix of smaller untwinned clear dolomite grains. The outlines of the larger plates, being governed by those of the small ones, appear denticulate.

At the True Blue quarry (see $\mathrm{Pl}$. XV, $A$, and fig. 18, p. 125) there is a 15 -foot bed of dolomite with calcite marble on both sides of it. A drill core at West Rutland shows nine dolomite beds from 1.8 inches to 16 feet thick, alternating with beds of calcite marble. The whole series measures 250 feet 7 inches, out of which the dolomite beds measure 73 feet 9 inches.

A drill core at the Albertson quarry shows three or four dolomite beds from 4 to 22 feet thick alternating with beds of calcite marble, the whole series measuring 94 feet 4 inches.

At the Florentine quarry in Pittsford the bluish-gray calcite marble contains nodules of very dark gray dolomite. The nodules are brecciated and veined with calcite and quartz. In thin section they are seen to consist of graphitic dolomite.

At the Valley quarry of the Norcross-West Marble Co. at South Dorset there is a 10-foot bed of dolomite at the northeast end of the quarry in contact with the marble. This consists of dolomite grains tending to rhombic outline, averaging about 0.1 millimeter in diameter. The larger particles are cloudy and full of minute dark specks, sparse quartz, a little vein quartz, and pyrite (?).

At the Eastman quarry in West Rutland (see Pls. I, IV) there is a dove-colored dolomite on the east side of the marble beds, which is finely veined with quartz and weathers a delicate pale brown. It consists of grains of dolomite, rarely rhombs, averaging 0.028 millimeter in diameter, with sparse small quartz particles and intersecting quartz veins, some of these with large dolomite plates; also 


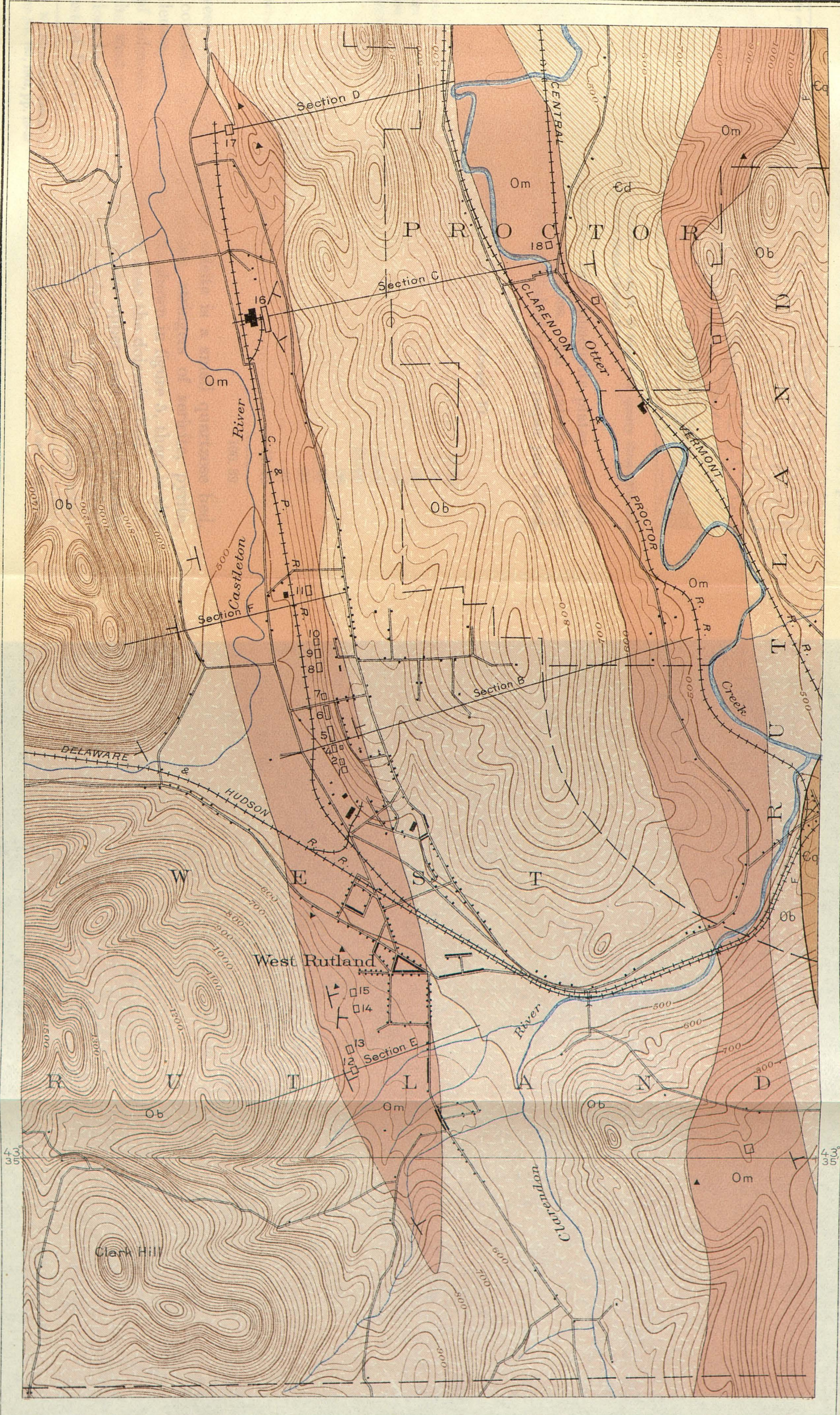

LEGEND

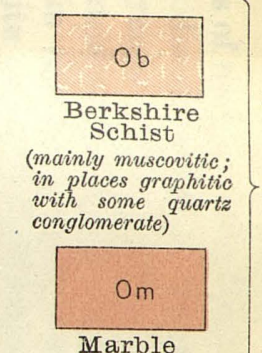

$z$
$\frac{1}{0}$
0
0
0
0
0
0

Marble

(including dolo-
mite beds)
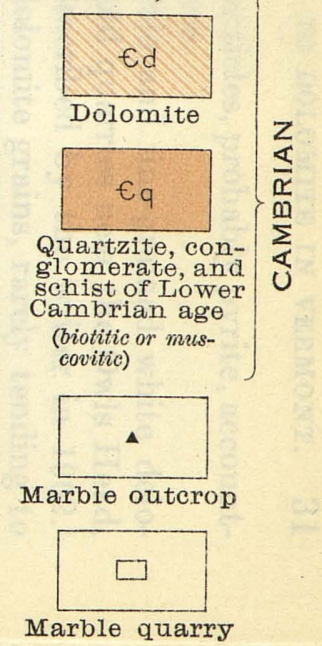

rble quarr

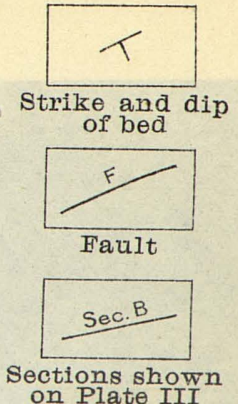

octions shown
on Plate III

QUARRIES

I. "Covered"

2.

3.

4. Gilson

5. Ripley

6. Baxter

7. Prospect

8. Clement

9. Foster

10. Sherman

1. "Old Open"

12 Eastman

13. Morgan

14. Umbrella

15. Rutland-Florence

16. Albertson

17. True Blue

18. Riverside 

a few flakes of muscovite and dark particles, probably pyrite, accounting for the discoloration of the surface.

Coarse-grained white calcite marble and fine-grained white dolomite are interbedded in one of the old quarries near the Owls Head, as shown in figure 5. This was described by the writer in 1902. ${ }^{1}$ The dolomite consists of irregular dolomite grains, rarely tending to rhombic form, averaging about 0.06 millimeter in diameter, sparse

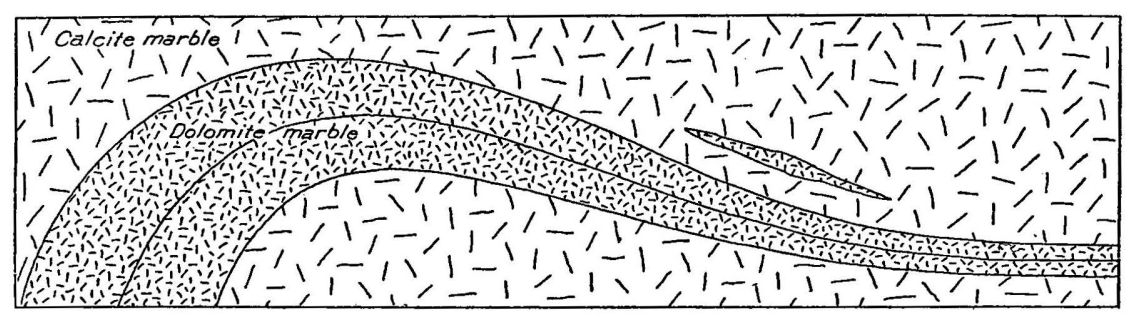

FIGURE 5.-Interbedded calcite marble and dolomite. Length, 40 feet. Old quarry three-fifths mile west of the Owls Head, Dorset, vt.

quartz grains up to 0.12 millimeter, rare muscovite plates and feldspar grains, and minute opaque particles. An analysis of it by George Steiger, of the Survey, first published in the paper just cited, is as follows:

Analysis of whitish dolomite from quarry in Dorset, Vt.

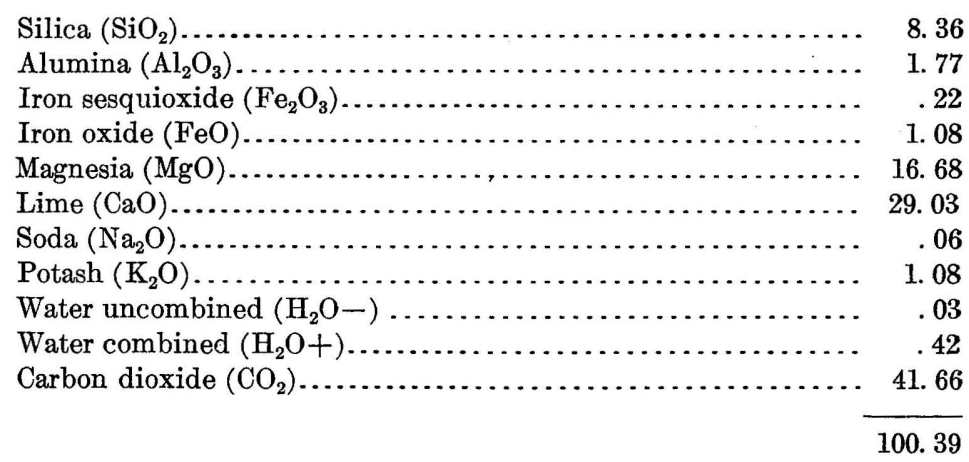

Between the dolomite and the calcite is a small quartzose bed, which contains sparse quartz grains, stringers of sericite, pyrite, quartz lenses, and calcite plates. As shown in figure 5, there is also a lens of dolomite in the marble and near the dolomite bed.

On the west side of Pine Hill, in the upper part of the marble series close to its contact with the overlying schist, $1 \frac{1}{2}$ miles southsoutheast of Proctor (see Pls. I and IV), is a bed of gray and white

1 Dale, T. N., Structural details in the Green Mountain region and in eastern New York: Bull. U. S. Geol. Suryey No. 195, 1902, pp. 13-15, 
mottled calcite marble containing angular and roundish fragments of dolomite, ${ }^{1}$ which, being less soluble by atmospheric acid than the rest of the rock, project on the weathered surface. The marble shows calcite with grain diameter of 0.05 to 0.37 millimeter; the dolomite consists of large irregular plates 0.25 to 1.5 and small grains avoraging roughly 0.07 millimeter. The dolomite fragments range from an inch or over down to 0.1 inch in diameter. This association of dolomite and calcite appears to be due to the brecciation of a series of alternating small beds of dolomite and calcite marble.

The calcite marble of the Florence No. 2 quarry in Pittsford (see map, Pl. I) is of a very light bluish-gray color with dark-gray mottlings, which form minute projections on the polished face that can be scratched with a knife. In thin sections this is seen to be a medium-textured marble, with grain diameter averaging 0.24 millimeter, inclosing minute bands or lenses of dolomite, some of it in rhombs, with a grain diameter averaging, roughly, 0.15 millimeter, and a few quartz grains and muscovite scales. The mottled calcite marble of the Turner quarry, "Pittsfield Italian," has similar minute beds of dolomite. A sketch of one of these in natural size is shown in figure 20, page 131. The marble of the Landon quarry has similar little dolomite beds. (See p. 135.)

The slightly bluish-white, gray-streaked calcite marble near the base of the marble beds, quarried near Clarendon village (see p. 110), has calcite grains mostly from 0.12 to 0.5 millimeter in diameter, and contains bands of dolomite of irregular and rhombic grains averaging roughly 0.06 millimeter.

A banded calcite marble at a disused quarry three-fourths of a mile southwest of the top of Boardman Hill, in Clarendon, belonging near the top of the marble beds, consists of black, dark-gray, and whitish parallel bands from 0.02 to 0.5 inch thick. In thin section some of these little beds are seen to consist of calcite grains from 0.12 to 0.75 millimeter in diameter, some of them full of graphite; others have calcite with a grain diameter from 0.07 to 0.25 millimeter. But some of the beds are dolomite with an average grain diameter of 0.06 millimeter and with some large dolomite plates of 0.09 millimeter. Some of the calcite bands also contain small lenses of dolomite.

The most interesting combination of calcite and dolomite is the black marble of Isle la Motte. (See p. 47 and fig. 9.) The dark bluish-gray weathered surface of this black marble, which effervesces freely with acid, shows little irregular beds of brownish-gray color which effervesce less freely and form a network about and between the fossil fragments. In thin section this rock is seen to consist of irregular alternations of dolomite. in rhombs 0.02 to 0.1

1 This bed was referred to by Hitchcock and Hager (Geology of Vermont, vol. 1, 1861, p. 399). 
millimeter in diameter and of fossiliferous calcite bands. In the gray crinoid marble bed of the same quarry (p. 48) some of the crinoid columns are of calcite with twinning planes bisecting the acute angle of the cleavage rhomb, but the matrix contains rhombs of dolomite.

The black unmetamorphosed marble of Isle la Motte, with its large Maclureas and other Chazy fossils, may be safely regarded as a close approximation to the condition of the Chazy limestone in the metamorphic marble belt of Vermont before metamorphism took place; and the association of dolomite and calcite in the one throws light on their association in the other, particularly in those parts of the rock where the dolomite forms minute lenses or bands in the calcite marble. These bands were there prior to regional metamorphism.

Exploration of the marbles in eastern Vermont, the results of which will appear in a later bulletin, brings out the fact that the calcite marbles there are also interbedded with dolomite, but generally in beds from a fraction of an inch to several inches thick, and that this dolomite, although fine grained, is almost everywhere twinned, whereas in western Vermont it is mostly untwinned, "granular."

\section{THE ORIGIN OF DOLOMITE.}

Much has been written on the origin of dolomite, and some facts have been definitely established.

Dolomite may be formed in the ocean by the chemical action of sea water substituting magnesium for part of the calcium in a deposit of calcium carbonate or in a coral. The best evidence of this is the drill core obtained by a boring made on the coral island of Funafuti under the direction of the Royal Society. ${ }^{1}$ The bore hole was 1,114 feet deep and penetrated a rock of organic origin, consisting of various alternations of calcitic and dolomitic rock. The percentage of $\mathrm{MgCO}_{3}$ (magnesium carbonate) was inconsiderable down to 640 feet, where it was 26.33 por cent. From 698 feet down to 1,114 feet it ranged from about 39 to 41 per cent. As the percentage of magnesium carbonate in living coral and in the calcareous parts of other marine organisms is insignificant, and as the salts of the sea, which make up 3.737 per cent of the water, contain 1.676 per cent of $\mathrm{CaO}$ (lime), or 1.196 per cent of $\mathrm{Ca}$ (calcium), and 6.209 per cent of $\mathrm{MgO}$ (magnesia), or 3.769 per cent of $\mathrm{Mg}$ (magnesium), it is thought that the magnesium in the dolomitic beds of this organic rock may have been supplied by the sea through a process of dolomitization. ${ }^{2}$

\footnotetext{
1 The atoll of Funafuti, Royal Soc. London, 1904.

2 Instructive papers on this subject are those of Skeats, E. W., The chemical composition of limestones from upraised coral islands, with notes on their microscopic structures: Bull. Mus. Comp. Zool. Harvard Coll., vol. 42, 1903, p. 53; On the chemical and mineralogical evidence as to the origin of the dolomites of southern Tyrol: Quart. Jour. Geol. Soc. London, vol. 61, 1905, p. 97.
}

$49311^{\circ}-$ Bull. 521-12—3 
Dolomite has also been formed by the dolomitization of a limestone after its emergence from the sea. Unmistakable evidences of this process have been found in Ireland and other places. ${ }^{1}$

In these localities dolomitization was brought about after emergence by percolating waters carrying magnesium carbonate in solution, which was substituted for part of the calcium carbonate in the limestone. Whether these magnesian waters came indirectly from the sea or directly during a second submergence is not clear.

Dolomite has also, it is asserted by some geologists but disputed by others, been formed by chemical precipitation in the sea. Archibald Geikie ${ }^{2}$ says that dolomite "occurs sometimes in beds of original deposit, associated with gypsum, rock salt, and other results of the evaporation of saturated saline waters; it is also found replacing what was once ordinary limestone." Zirkel ${ }^{3}$ maintains that the direct precipitation of dolomite is just as possible as that of calcite. Strahan ${ }^{3}$ describes a 4 -foot seam of coal in one of the English collieries which in a space of 750 feet passes into a 3 -foot bed of pure dolomite and the origin of which is attributed to direct deposition. ${ }^{4}$

Loretz ${ }^{5}$ described certain fine foliaceous dolomites, the texture of which in his opinion points strongly to direct deposition. Gümbel ${ }^{6}$ regards the interbedding of dolomite and limestone, the occurrence of lenses of dolomite in limestone, the strict separation of dolomite from overlying limestone, and the distinct bedding of the dolomite as all pointing to the original sedimentation of dolomite.

On the other hand, Doelter and Hoernes regard the greater part of dolomite as due to the calcareous secretions of marine organisms dolomitized probably by magnesium chloride in sea water. ${ }^{\text {? }}$

Klement ${ }^{8}$ regards it as formed by concentrated sea water in solarly superheated closied basins acting upon aragonite deposited by marine organisms. Aragonite is that form of $\mathrm{CaCO}_{3}$ which constitutes corals, shells, etc.

\footnotetext{
1 See Wyley, Andrews, On the character and mode of occurrence of the dolomitic rocks of Kilkenny: Jour. Geol. Soc. Dublin, vol. 6, 1856, pp. 114-119, figs. 1-3, showing a vertical "dike" of dolomite 1 to 2 feet thick crossing horizontal beds of limestone, also dolomite replacing the upper part of a series of horizontal and undulating beds of limestone, the boundary between the two rocks zigzagging most irregularly across the bedding planes. See also Harkness, Robert, On the jointings in the Carboniferous and Devonian rocks in the district around Cork; and on the dolomites of the same district: Quart. Jour. Geol. Soc. London, vol. 15, 1859, p. 100 . Dolomitization has operated along the joints of the limestone.

2 Textbook of geology, vol. 2, p. 193.

${ }^{3}$ Zirkel, F., Lehrbuch der Petrographie, 2d ed., vol. 3, 1894, p. 502.

4 Strahan, A., On the passage of a seam of coal into a seam of dolomite: Quart. Jour. Geol. Soc. London, vol. 57, 1901, pp. 297-306.

5 Loretz, H., Untersuchungen über Kalk und Dolomit: Zeitschr. Deutsch. geol. Gesell., vol. 30, 1878, pp. 387-414, Pls. XVII, XVIII; vol. 31, 1879, pp. 756-774.

B Gümbel, C. W., Die geognostischen Verhältnisse des Ulmer Cementmergels, seine Beziehungen zu den lithographischen Schiefer und seine Foraminiferen Fauna: Sitzungsb. K. b. Akad. München, 1871, pp. 38-62.

7 Doelter, C., and Hoernes, K., Chemisch-genetische Betrachtungen über Dolomit: Jahrb. K.-k. geol. Reichsanstalt, vol. 25, 1875, pp. 297-332.

8 Klement, C., Sur l'origine de la dolomie dans les formations sédimentaires: Mém. Soc. belge géol., pal. et hydrol., vol. 9, 1895, pp. 3-23; abstract in Geol. Mag., London, new ser., dec. 4, vol. 2, 1895, p. 329.
} 
Pfaff ${ }^{1}$ attributes dolomite to the dolomitization of $\mathrm{CaCO}_{3}$ (either as chemical precipitate or of organic origin) during or after its deposition.

Hunt's early experiments ${ }^{2}$ demonstrated that precipitations of a mixture of calcium carbonate and hydrated magnesium when heated above $120^{\circ}$ pass into dolomite.

Van Hise ${ }^{3}$ and Clarke ${ }^{4}$ do not consider the chemical precipitation of dolomite as probable under any conditions.

Linck ${ }^{5}$ attributes the origin of dolomite largely to ammonium salts arising from organic decomposition, basing this theory on certain laboratory experiments.

In connection with the question of the origin of dolomite, attention should be called to the alternation of dolomitic and calcitic beds observed in many places besides those described in the previous pages.

Vogt ${ }^{6}$ gives a section at Furuli, in Fauske, Norway, showing a series of beds 146 feet thick consisting of 48 feet of slatc overlying 57 feet of plicated fine-grained limestone, which overlies a series made up of two beds of yellow calcite marble altornating with two of dolomite marble, each bed about 12 feet thick and all plicated and without any transition from the dolomite to calcite marble. It is evident that such repeated alternations of dolomite and calcite can not be explained by dolomitization after emergence, nor can the kindred occurrences in the Vermont marble belt at West Rutland and in Dorset (described on pp. 30-32) be explained in that way.

The interbedding of dolomite and limestone is very characteristic of the limestone belt in Lehigh County, Pa., particularly in the town of South Whitehall. At a quarry visited by the writer in 1892, on the south side of Jordan Creek near Jordan Bridge (see map of Slatington quadrangle, U. S. Geol. Survey), three beds of dolomite, each 18 inches to 2 feet thick, alternate with four beds of limestone averaging about 15 feet thick. The whole series is intricately folded, there being three anticlines and three synclines in a length of 100 feet; and the limbs of these folds measure from 12 to 35 feet in length. The limestone emits a fetid odor when struck with the hammer. In thin sections the limestone is seen to consist of finely stratified irregular plates of polarizing calcite, 0.004 to 0.02 millimeter in diameter, crossed by irregular beds or veinlets of black carbonaceous matter, with lenses of calcite and rhombs reaching 0.2 millimeter, and a little pyrite. The dolomite consists of grains,

1 Pfaff, F., Ueber Dolomit und seine Entstehung: Neues Jahrb., Beilage Band 23, 1907, pp. 529-580.

2 Hunt, T. S., Am. Jour. Sci., 2d ser., vol. 28, 1859, pp. 170, 365; vol. 42, 1866, p. 49.

8 Van Hise, C. R., A treatise on metamorphism: Mon. U. S. Geol. Survey, vol. 47, 1904, pp. 798-808.

4 Clarke, F. W., The data of geochemistry, 2d ed.: Bull. U. S. Geol. Survey No. 491, 1911, pp. 534-543, particularly p. 540 .

5 Linck, G., Monatsh. Deutsch. geol. Gesell., 1909, p. 230. See also Clarke, F. W., The data of geochemistry, 2d ed.: Bull. U. S. Geol. Survey No. 491, 1911, p. 536.

${ }^{6}$ Vogt, J. H. L., Der Marmor: Zeitschr. prakt. Geologie, 1898, p. 9, fig. 5. 
mostly rhombs, of dolomite, from 0.05 to 0.15 millimeter in diameter, averaging about 0.1 millimeter, in a slight very dark matrix.

Chemical analyses of both rocks made for the writer's study of this subject in 1903 by W. F. Hillebrand follow. The limestone was taken immediately under one of the dolomite beds.

Analyses of limestone and dolomite, near Jordan Bridge, South Whitehall, Pa.a

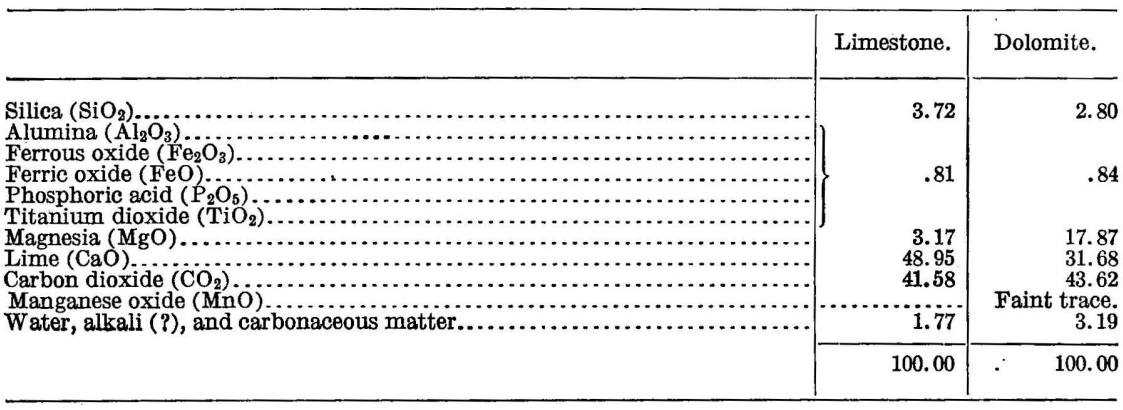

$a$ Bull. U. S. Geol. Survey No. 419, 1910, p. 190 (slightly abbreviated from original).

The carbonates in these analyses figure out as follows: Magnesium carbonate $\left(\mathrm{MgCo}_{3}\right), 37.52$; calcium carbonate $\left(\mathrm{CaCO}_{3}\right)$, 55.65. These analyses show that both rocks contain quartz and carbonaceous matter and that the dolomite contains 10 per cent more $\mathrm{CaCO}_{3}$ and about 7 per cent less $\mathrm{MgCO}_{3}$ than a normal dolomite.

In the dolomites of Green Peak, Vt. (p. 31), the percentage of $\mathrm{SiO}_{2}$ (silica) is 8.36 , most of which, according to the sections, occurs as quartz and the rest in mica and feldspar. The statuary-marble bed of the Goodell quarry, near Brandon (p. 137), is in contact with a graphitic quartzose dolomitic calcitic rock. The presence of more silica in the dolomite beds of the Vermont marble belt than in the adjacent calcite marble beds points to conditions of sedimentation different from those which prevailed when the calcite beds, were being deposited.

How shall these microscopic beds of dolomite in the black unmetamorphic marbles of Isle la Motte and in some of the finely banded metamorphic marbles of the Vermont valleys (p. 32) be explained? The same question may be asked as to the minute interbedding of dolomite and sericite schist, each a millimeter thick, in a plicated rock in the Alps, in which, of course, the schist was of mechanical sedimentary origin. ${ }^{1}$ However the alternation of dolomitic and calcitic beds mayy be explained, the sharply defined and repeated alternations indicate great differences in the conditions of original sedimentation or in those conditions which brought about and arrested the process of submarine dolomitization.

\footnotetext{
I See Allenspach, G., Dünnschliffe von gefälteltem Röthidolomit-Quartenschiefer am Piz Urlaun: Vierteljahrsschr. Naturforsch. Gesell. Zürich, vol. 45, 1900, pp. 227-237.
} 
WEATHERING OF MARBLE.

The weathering of marble is governed by four factors-the chemical composition of the marble, its texture, the general character of the climate to which it is exposed, and the local artificial conditions of the surrounding atmosphere.

Both calcite and dolomite marble are soluble in carbonic acid, which is brought down from the atmosphere in every drop of rain water; but as dolomite is less readily soluble in this acid than calcite a dolomite marble, the other factors being equal, will prove more durable than a calcite marble. (See p. 27.)

It has been thought that a fine-textured marble, by offering the rain water a greater length of grain boundary than a coarse-textured one, would weather more readily, but on the other hand a coarsetextured, loosely compacted marble will weather readily because acid water, once admitted between the grains, will travel more rapidly. ${ }^{1}$ Marbles containing silicates in large flakes or crystals are more susceptible to weathering, for acid water gains free access along the boundaries of the silicates.

It is generally known that carvings in European marbles will stand exposure in the climate of southern Europe much better than in that of our Eastern States. Vogt states that in the dry atmosphere of Egypt, Greece, and Italy marble statues after an exposure of 1,000 years lose some of their fine lines but become coated with a fine protective crust. Lepsius found that this protecting film on ancient Greek monuments was ferruginous and that it was formed only on the marbles containing a small percentage of $\mathrm{Fe}_{4} \mathrm{O}_{9} \mathrm{H}_{6}$. On the other hand Vogt refers to a number of Norwegian churches built partly or entirely of Norwegian calcite marble which have stood six or seven centuries exposed to the raw, windy, and cold climate of northern and western Norway with but very little if any weathering. In contrast with this Hirschwald ${ }^{2}$ reproduces a thin section of marble, presumably Italian, which had been exposed in a monument in Berlin for 192 years and which shows the erosion of the grain surfaces, the loosening of their cohesion, and the deposition of an ocher-like substance between them.

The amount of weathering, other things being equal, is probably related to the degree of humidity of the atmosphere and the amount of rainfall. Though it is mainly due to carbon dioxide brought down by rain, it is probably due in part, as pointed out long ago by Joseph Henry, to nitric acid generated by lightning. ${ }^{3}$

\footnotetext{
1 Vogt, J. H. L., Der Marmor: Zeitschr. prakt. Geologie, 1898, pp. 48, 49.

2 Hirschwald, J., Die Prüfung der natürlichen Bausteine auf ihre Wetterbeständigkeit, 1908, Pl. XVIIT, fig. 3.

${ }^{3}$ See Hall, James, Report on building stones: Thirty-ninth Ann. Rept. New York State Mus. Nat. Hist., 1886, p. 218.
} 
The effect on white marble of such a climate as that of New England, outside of the cities, can be observed in many country churchyards and cemeteries. As the epitaphs on tombstones and monuments give the approximate date of their erection the amount of solution by weathering in a century can be calculated. The cemetery on Burial Hill, at Plymouth, Mass., offers some pertinent data. On a marble stone in horizontal position, dated 1825, the lettering is almost effaced, and one of the same year in vertical position is badly weathered. On a horizontal stone of 1854 the edges of the letters are rounded. But slate stones from England, Wales, and New England in the same cemetery, dated 1683, 1743, 1745, 1773, and 1828, have well-preserved lettering. The good state of preservation of epitaphs on slate dating back to the early settlement of New England is noticeable in many other cemeteries. The climatic conditions at Plymouth were doubtless aggravated by fogs and salt air. At the other extreme may be cited a block of white marble taken in 1910 from a building near South Dorset, Vt., and probably quarried there, inscribed "A. D. 1831," in which the edges of the letters and figures are fairly sharp, having stood 79 years without perceptible weathering. Generally in New England, however, the lettering on white marbles 75 to 100 years old is so far weathered that it will probably be completely effaced within 300 years of the date of the cutting. It is also a question how long the letters on the marble headstones in the national cemetery at Arlington, Va., will stand the humid atmosphere of that region.

Geikie $^{1}$ in his paper on the weathering of tombstones notes the relative durability of epitaphs on marble and slate at Peterhead, in northeast Scotland. Epitaphs 100 to 150 years old on marble were half effaced, but some 110 years old on slate had retained their sharpness.

In considering the weathering of marble in the smoke-laden atmosphere of great cities and industrial centers we must take into account, besides the action of atmospheric acids, that of sulphuric acid arising from the smoke of railroads, factories, foundries, and steam plants where soft coal is used.

Geikie ${ }^{2}$ reproduces two thin sections of white marble, presumably Italian, one of the fresh stone obtained in an Edinburgh marble worker's yard, the other taken at right angles to the surface of an urn that had been exposed for 87 years in an Edinburgh cemetery. The second one shows that the acids have penetrated between the calcite grains and along the cleavage and twinning planes, widening them by solution, also that by a combination of sulphuric acid from

\footnotetext{
1 Geikie, Archibald, Rock weathering as illustrated in Edinburgh churchyards: Proc. Royal Soc. Edinburgh, vol. 10, 1880, p. 531 .

2 Idem, fig. 1, p. 520.
} 
the atmosphere with the lime of the calcite grains a crust of calcium sulphate (gypsum) has been formed in the openings and along the surface. Moreover this gypsum is full of dust and soot particles. From Geikie's examination of the marbles in that cemetery he estimates that weathering under the conditions at Edinburgh proceeds at the rate of 0.33 inch, or roughly 9 millimeters, a century. In other words lettering or designs cut 0.5 inch into marble would under such conditions be completely effaced in 150 years. In line with this conclusion is the fact stated by Goodchild ${ }^{1}$ that dressed surfaces of limestone in the north of England lose an inch of surface in from 240 to 500 years.

In this connection attention should also be directed to the rapid blackening of all light marbles by soot wherever much soft coal is used and to the fact that the amount of this disfigurement increases with the elaborateness of the ornamentation, which prevents its removal by rain.

Renwick, ${ }^{2}$ an English writer on marble, describes the effect of the London atmosphere on various marbles in these words:

Generally speaking, it appears that while certain varieties of marble are available for exterior work, their general use is inadvisable, for the reason that discoloration and disintegration will ensue as a result of atmospheric impurities, generally sulphuric acid, generated by the action of rain water falling through a smoke-laden atmosphere on a soot-covered building, the effect sought to be produced by their use being thus speedily lost, even if nothing worse happens. The red marbles mostly contain clayey veins and patches, which disintegrate under the action of sun, rain, and frost. With the greens effervescence results; the violets lose their color; while with breccias the colors fade and a leaching out becomes apparent along the line of the cementing medium of the material. Laminated marbles waste in their softer layers, leaving the harder parts exposed, and these in course of time will break away.

Seipp $^{3}$ has recently published an interesting study of the weathering of various marbles in Italian buildings and monuments. With the aid of a botanist he found that the blackening which is so conspicuous in exposed marble statues and carvings in that climate is due to a coating of the lichens Verrucaria, Opegrapha, and probably also Lithoicea, to particles of dust and soot adhering to the lichens, and to the film of humus arising from their decomposition.

\section{THE MARBLES OF WESTERN VERMONT.}

\section{GRAPHITIC CAICITE MARBLE.}

One of the marked varieties of Vermont marble is the gray, which ranges in shade from light to very dark and is generally of bluish tinge. Some of it is finely banded, light and dark, with some bands almost or quite black, as in the specimens from a disused quarry on Board-

1 Goodchild, J. G., Geol. Mag., 1890, p. 466.

2 Renwick, W. G., Marble and marble working, London, 1910, pp. 58, 59.

8 Seipp, H., Italienische Materialstudien, Stuttgart, 1911, pp. 23-35, 62-70, 117-153. 
man Hill, in Clarendon (p. 32), and from the Clarendon Marble Co.'s quarry in the same township (p. 111). Some of this gray marble is in sharply plicated beds crossed by planes of slip cleavage, as shown in the slabs photographed in Plates V, $A$, and VIII, $B, b$, in both of which the two sets of planes are conspicuous for their blackness.

In thin section all these gray marbles are characterized by a greater or less abundance of minute black particles, rarely scales of carbon disseminated in the calcite grains. An analysis (No. 2534) made by George Steiger, of this Survey, shows that in a typical specimen of this marble, "West Rutland blue," this carbon is graphite and that its percentage in the marble amounts to 0.03. Mr. Steiger adds the following explanation to his analysis:

This determination of graphite was made by the method proposed by Brodie. One hundred grams of the marble were dissolved in dilute hydrochloric acid, filtered through asbestos, and the insoluble residue (which contained all the carbon), together with the asbestos used in filtering, treated for eight days with strong nitric acid and potassium chloride. The residue from this treatment was light colored and showed no indication of any carbon being left unattacked. According to Brodie, who is confirmed by others, by this treatment amorphous carbon is oxidized to $\mathrm{CO}_{2}$, whilegraphite is oxidized to what is called graphitic acid, this compound being a light-yellow or brownish material. The solution was next filtered and the residue treated with a solution consisting of chromic and sulphuric acid, which oxidizes graphitic acid to $\mathrm{CO}_{2}$; the latter was passed through barium hydrate solution and the precipitated barium determined as sulphate.

Some few recent authorities do not consider this formation of graphitic acid as an absolute proof of graphite, but it is the most reliable test that can be made by chemical means.

In some of these marbles that are a little darker the percentage of carbon would be very little higher. The thin sections show that besides carbon a little quartz and pyrite are generally present, and less commonly muscovite.

If the calcite in these marbles is attributed to the calcareous parts of crinoids, brachiopods, and mollusks, the graphite is probably to be regarded as derived from the decomposition of marine algæ, and the fine interbedding of more or less graphitic parts to be attributed to alternating periods of dominant plant or animal marine life, but the abundance of the graphite in the planes of slip cleavage would have to be explained by transfers of graphite from the adjacent calcite grains during metamorphism.

These gray marbles take a high polish and are very attractive.

\section{CLOUDED CALCITE MARBLE.}

In the clouded calcite marble of Vermont the "clouds" generally follow the bedding planes, which in places are sharply plicated. An examination of the polished surface of one of these marbles with a magnifying glass shows that the cloudy bands project an infinitesimal distance above the general surface, and are therefore harder than 


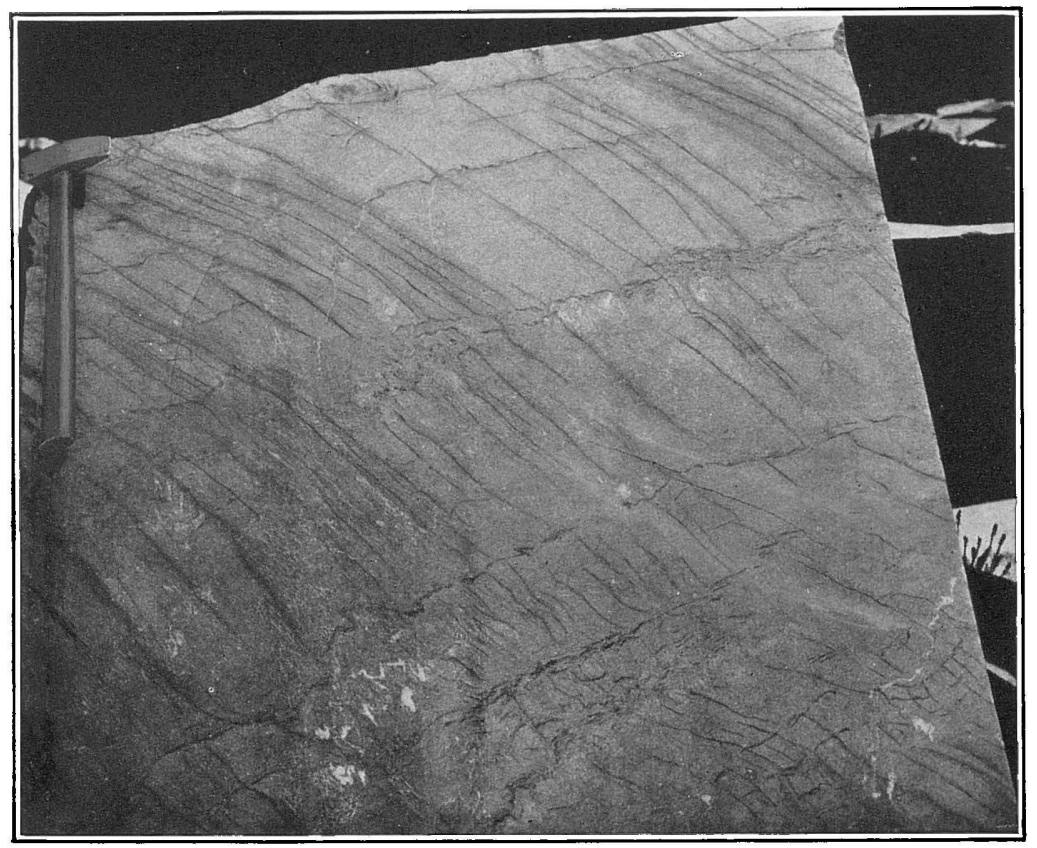

A. SAWN SLAB OF GRAPHITIC CALCITE MARBLE FROM THE TRUE BLUE QUARRY, WEST RUTLAND.

Showing planes of bedding and of slip cleavage laden with graphite. The beds are inclined to the left and the cleavage to the right. Hammer 18 inches.

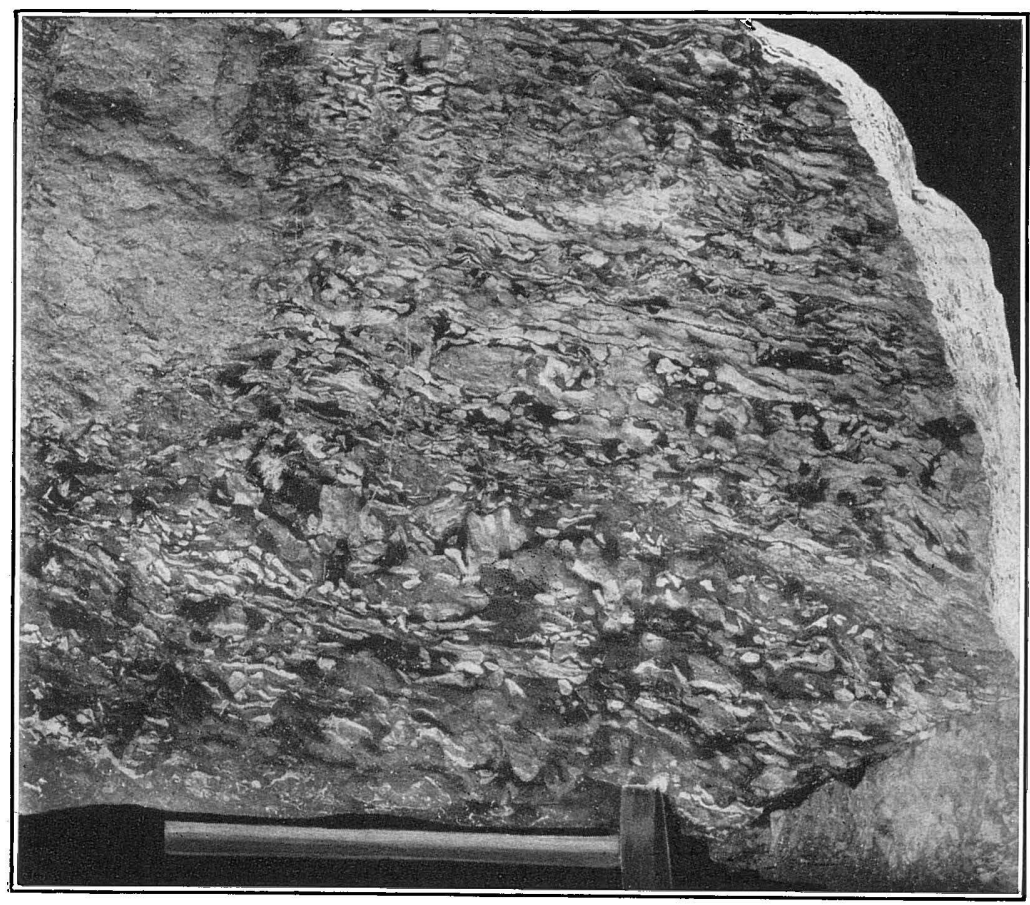

$B$. ROUGH BLOCK OF HEMATITIC DOLOMITE MARBLE FROM SWANTON.

Cut across the bed. The ground is bright reddish. Hammer 18 inches. 


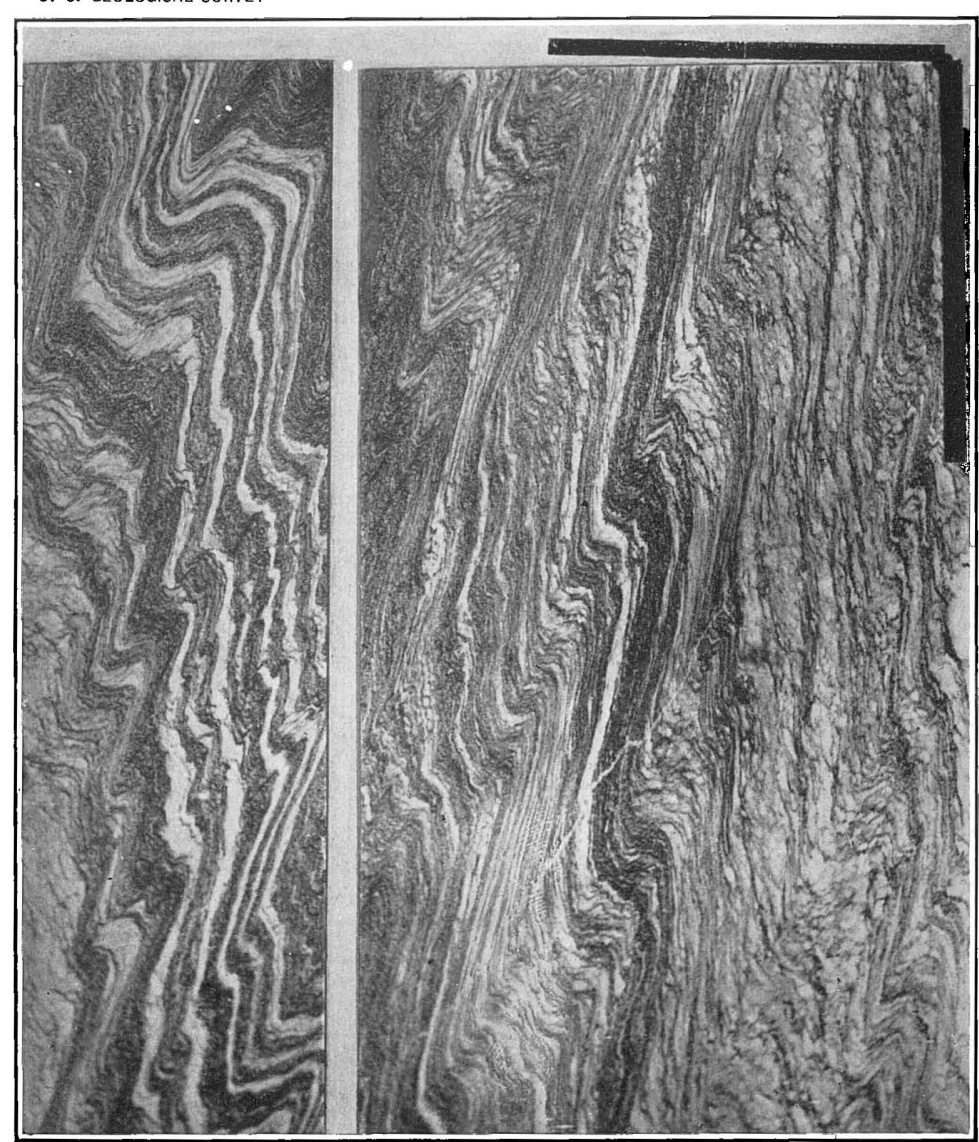

A. POLISHED SLAB OF PLICATED MUSCOVITIC CALCITE MARBLE FROM

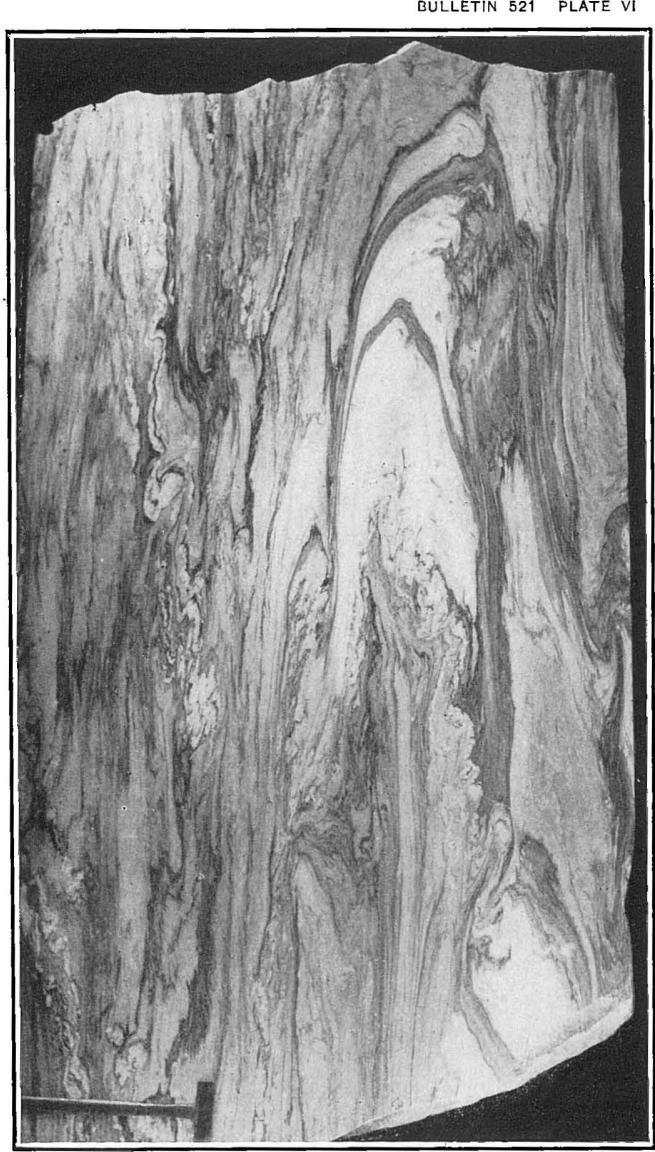

B. POLISHED SLAB OF PLICATED CLOUdED CALCITE MARBLE FROM THE NEW HOLLISTER QUARRY, 
calcite. As they can be scratched with a knife, they are softer than quartz. This is corroborated by a microscopic examination of thin sections, which shows that the cloudy parts consist mainly of dolomite with a grain diameter ranging from 0.02 to 0.25 millimeter, averaging, roughly, 0.15 millimeter. Associated with the dolomite are plentiful minute particles of graphite, which account for the dark shade; also some quartz, pyrite, and rarely muscovite. A still further corroboration is furnished by Penfield's analysis (p. 13) of one of these clouded marbles from the Columbian quarry, at Proctor, which shows 0.77 per cent of $\mathrm{MgCO}_{3}$ (magnesium carbonate). A sketch of one of these dolomite beds is shown in figure 20, page 131 .

Where the small cloudy beds are plicated, a slab sawn in the general direction of the stripe will intersect the tops of minute meandering anticlines, but if sawn in the direction of the dip it will intersect several superposed series of such plications. In either case the marble will be clouded, but the distribution of the "clouds" or bands will differ. Where the plication has been extreme, the mottling will be very irregular on the slab. A polished slab of one of these clouded calcite marbles containing some slightly graphitic calcitic beds is shown in Plate VI, $B$.

\section{MUSCOVITIC CALCITE MARBLE.}

Many of the banded marbles of western Vermont owe their banding to fibers and scales of muscovite mingled in varying amounts with the calcite grains

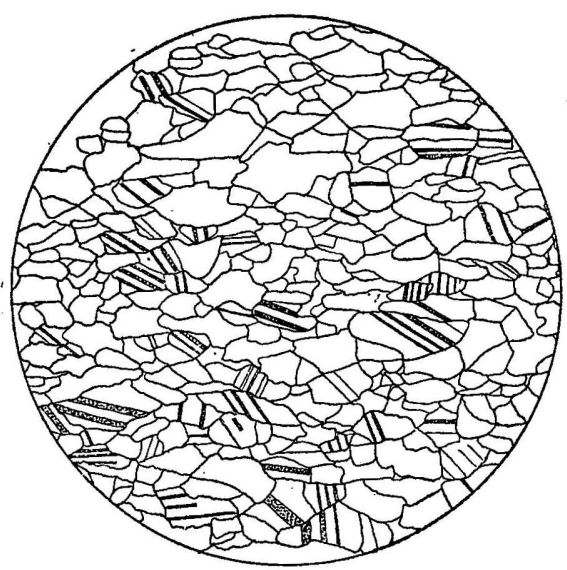

FIGURE 6.-Thin section of graphitic calcite marble showing elongate texture. From "17-foot bed," Eastman quarry, West Rutland. Enlarged 27 diameters.

and forming little beds which alternate with beds of calcite grains alone. The marble has a grayish or greenish tint of varying intensity. The whole series of beds is generally more or less intricately plicated. Slabs showing cross sections of such a series are used for ornamental wainscoting and panels. (See Pls. VI, $A$, and XIV, B.)

In these marbles the long axes of the calcite grains are generally parallel to the bedding, as shown in figure 6 , so that the marble has under compression acquired a certain schistosity. In thin section the fibrous muscovite is found associated with quartz grains, rarely one of plagioclase feldspar, also with epidote and chlorite, which emphasize the greenish tint proceeding from the muscovite. In some beds the muscovite, epidote, and chlorite are distributed so 
uniformly through the calcite as to produce a bright-greenish marble. Along with these minerals are usually found small dark lenses of uncertain character, minute opaque specks, and a little pyrite.

The fibrous muscovite of these marbles must have originated in clayey (feldspathic, quartzose) sediment, of which the few plagioclase grains are unaltered remnants and most of the quartz possibly also.' The epidote and chlorite must have originated in minerals containing magnesia, silica, iron, and alumina, with which, to form the epidote, lime from the calcareous sediments became combined. These mechanical sediments, combined with calcareous sediments, presumably of organic origin, were metamorphosed, as already explained

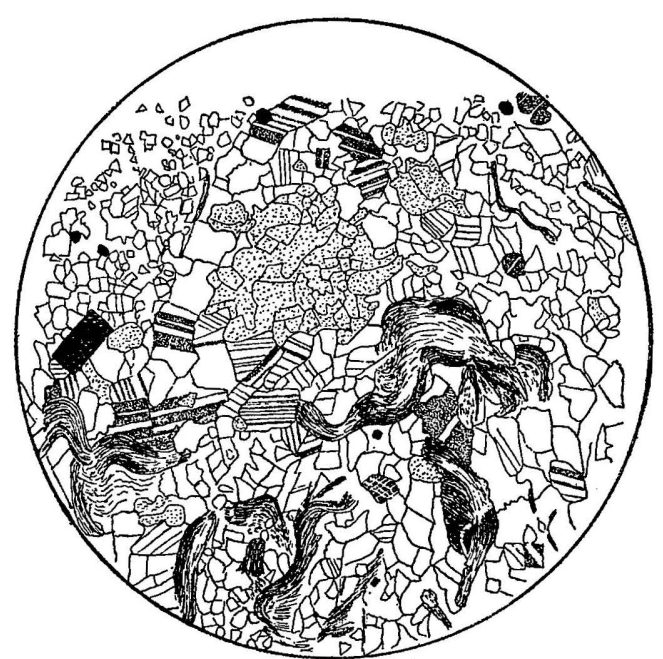

FIgURE 7.-Thin section of quartzose dolomitic and sericitic calcite marble from knoll near Brandon. Dotted particles are quartz; finer-grained area at upper left side is dolomite; the fibrous portions consist of sericite, which, where shaded, is graphitic; the black particles are pyrite; the larger clear particles and the banded particles are calcite. Enlarged 27 diameters. (p. 23), into muscovitic calcite marble containing small quantities of accessory minerals.

About $1 \frac{1}{2}$ miles southwest of Brandon in the marble belt (see Pl. I) is a knoll rising 120 feet above the Otter Creek flood plain and consisting of rusty-weathering impure bluish marble that illustrates well the effect of metamorphism on a mass of calcareous sandy and clayey marine sediments. Part of a thin section of this rock is reproduced in figure 7 . In some places the rock is a medium-grained calcite marble, containing some quartz. In others it is a fine-grained dolomite, including lenses of calcite and quartz. In still others it is a graphitic, pyritiferous sericite schist. The whole mass is intricately plicated and crossed by planes of slip cleavage. It combines some of the features of a marble with some of quartzite, some of dolomite, and some of a muscovite (sericite). schist. The muscovitic calcite marbles are the result of the same processes which produced this rock, but the sediments were more dominantly calcareous.

Owing to their considerable content of mica, the muscovitic calcite marbles do not take a perfect polish. 


\section{ACTINOLITIC CALCITE MARBLE.}

Exceptional among the Vermont marbles are those quarried a mile northwest of South Dorset or $1 \frac{1}{4}$ miles southwest of the Owls Head, in Dorset. (See Pl. I and p. 99.) They are coarse textured and range from faintly greenish or cream to smoke colored. Some beds are banded with fine dark-green to grayish-green beds, acutely plicated at intervals. Thin sections show that these little beds consist of fibrous actinolite and quartz with some pyrite and minute dark lenses of uncertain composition. The smoke-colored parts appear to owe their shade to thinly disseminated lenses of this kind.

This actinolite (a variety of hornblende, a silicate of lime, magnesia, and iron) must be attributed to the metamorphism of material of mechanical sedimentary origin containing magnesia, iron, and silica, combined with lime from the calcareous sediments.

Plate VII shows two pilasters of this actinolitic marble cut parallel to the strike, with some plication and a little brecciation along the strike.

\section{DOLOMITE MARBLES OF LAKE CHAMPLAIN.}

The marbles commercially known as "Champlain marbles" differ greatly in composition, texture, color, and physical qualities from the marbles that are extensively quarried along the Taconic Range. They owe their name to their occurrence in a strip along or near the east shore of the northern part of Lake Champlain. They include the marbles of Swanton, which are of Lower Cambrian age, and those of Monkton, along the foot of the Green Mountain range, which are probably areally continuous with and of the same geologic age as those of Swanton.

For the geology of these marbles the reader is referred to the writings of the Vermont and other geologists. ${ }^{1}$

SWANTON.

The marbles of Swanton are all quartzose dolomites, most of the quartz being in angular particles (0.02 to 0.15 , generally under 0.07 millimeter across) and thus of mechanical sedimentary origin. The quartz grains have cavities with moving vacuoles. Rare grains of feldspar (orthoclase, microcline, and plagioclase) occur with them. The dolomite is in irregular untwinned plates and rhombs (0.02 to 0.3 , averaging roughly 0.1 millimeter in diameter). The rock is more or less pinkish or reddish from minute particles of hematite $\left(\mathrm{Fe}_{2} \mathrm{O}_{3}\right)$

1 See Perkins, G. H., The Winooski or Wakefield marble of Vermont: First Rept. State Geologist, 1898, pp. 30-37; Second Rept., 1900, pp. 55, 56; Sixth Rept., 1908, pp. 28-30, 224-245. Hitchcock, C. H., The Winooski marble of Colchester, Vt.: Proc. Am. Assoc. Adv. Sci., vol. 16, 1867, p. 119. Billings, E., Note on the discovery of fossils in the Winooski marble at Swanton, Vt.: Am. Jour. Sci., 3d ser., vol. 10, 1872, pp.145-146. Edson, G. E., Geology of the town of Swanton: Sixth Rept. State Geologist, 1908, pp. 217-219. 
disseminated in the dolomite grains and also as a matrix between them. This reddish matrix is not slaty, for in cross sections it fails to show aggregate polarization. As the marble has a marked argillaceous odor, kaolin may be present. The hematite in places is seen to arise from the oxidation of black metallic particles which also show on the polished face and easily cling to a common magnet when the rock is powdered, do not appear reddish on the edges, and have a blackish streak. The rock in which the magnetite abounds has a purplish color. A grayish to reddish variety near the base of the series and certain bluish-gray beds near the top, weathering yellow, show limonite stain proceeding from abundant minute grains of pyrite. The first variety shows magnetite also, rarely oxidized to hematite. Some of the sections of the "red" show a little mica

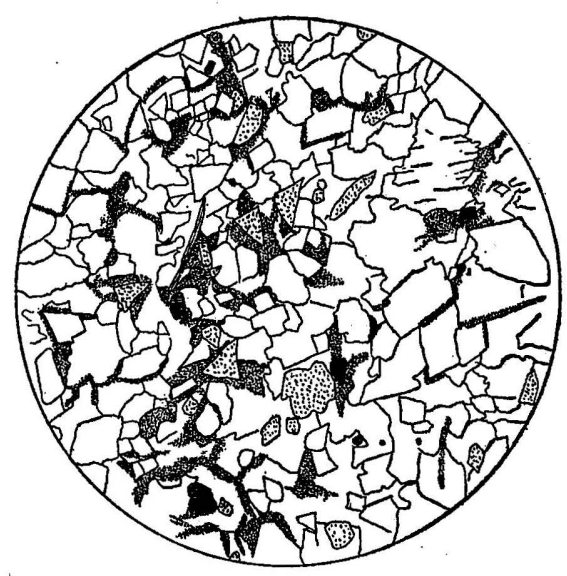

FIGURE 8.-Thin section of hematitic quartzose dolomite from Swanton. Dotted particles are quartz; black are magnetite; shaded areas are hematite stain; a black-banded particle is plagioclase, a long-streaked one, muscovite; the rest are dolomite. Enlarged 77 diameters. trix containing very irregular light-pink to white dolomitic lenses or beds 0.1 to 0.7 inch wide and up to 9 inches long, generally with their long axes parallel to the bedding but in some beds at all angles to it, even perpendicular. Some of these lenses consist of coarse twinned dolomite and calcite with a nucleus of vein quartz. These are regarded by Walcott ${ }^{1}$ as Actinozoa (corals), Archæocyathinæ, originally more or less conical in form but now greatly distorted.

Perkins regards the present position of some of these lenses as due to brecciation, but however that may be the nucleated structure and

\footnotetext{
1 Walcott, C. D., The fauna of the Lower Cambrian, or Olenellus zone: Tenth Ann. Rept. U. S. Geol. Survey, pt. 1, 1890, pp. 587, 588. In a letter of recent date Dr. Walcott adds: "As far as we know, this group of fossils on the North American continent, both on the coast of Labrador and in southwestern Nevada, is associated with the Lower Cambrian, and the same is true in northwestern Vermont.".
} 


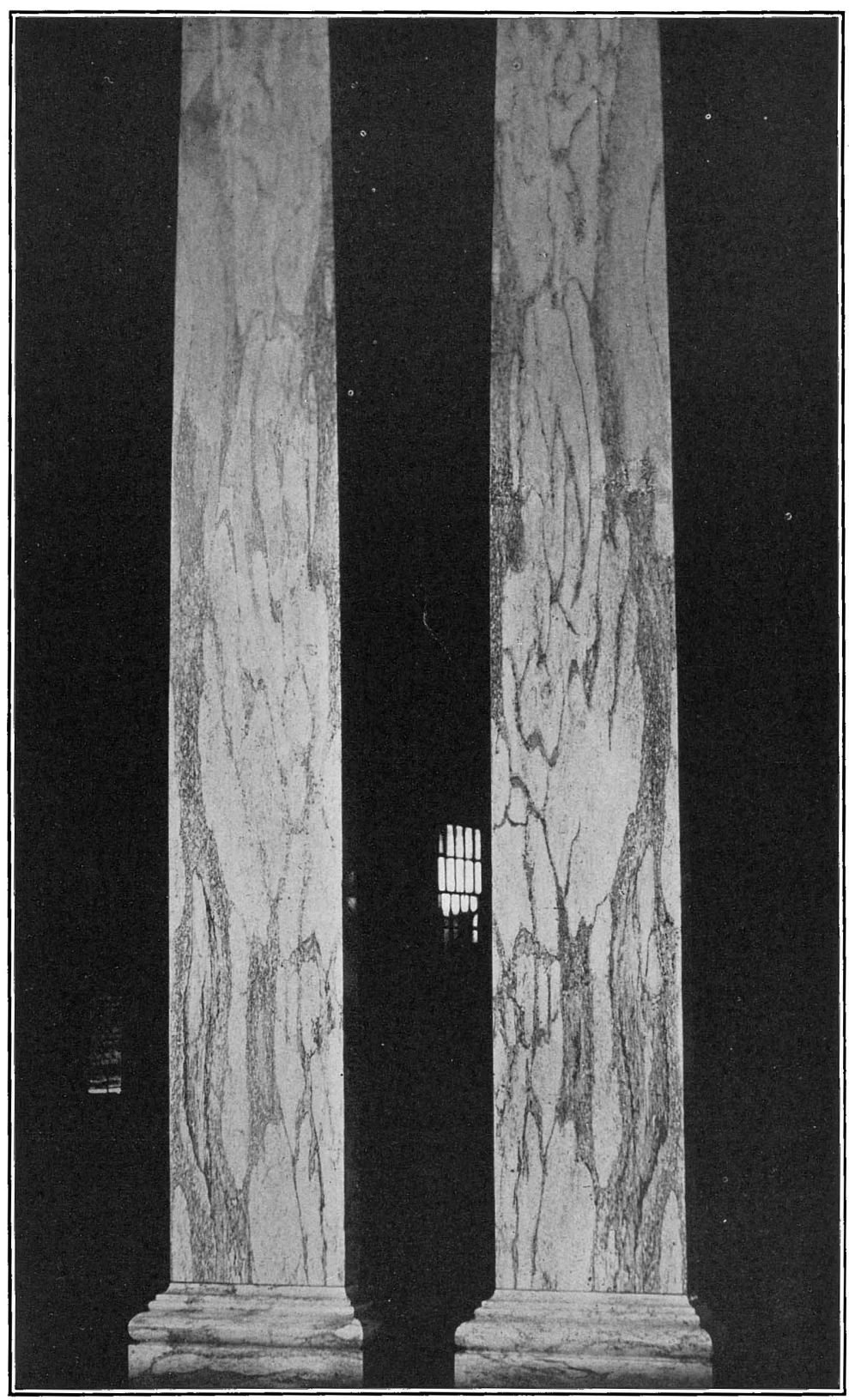

POLISHED PILASTERS OF ACTINOLITIC CALCITE MARBLE FROM "GREEN BED," VALLEY QUARRY, SOUTH DORSET.

Showing some brecciation along the strike. Length 11 feet 3 inches, width 20 inches. 


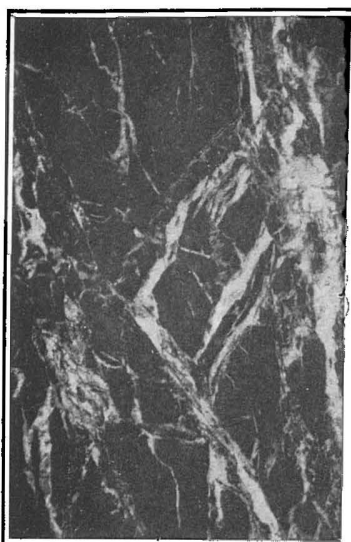

(a)

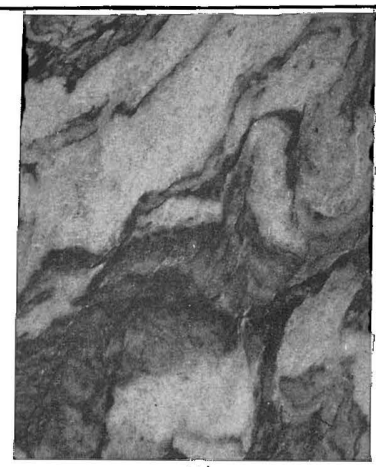

(b)

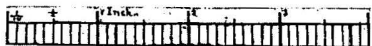

$A$.

$a$, SERPENTINE FROM ROXBURY, SHOWING VEINING.

$b$, "KIEL'S GREEN MARBLE," FROM EASTMAN QUARRY, WEST RUTLAND.

Alternating beds of cream-colored calcite marble and dark-green muscovitic and chloritic marble, both plicated and crossed by slip cleavage.

\section{$c$, "JASPER" MARBLE FROM SWANTON.}

The ground is bright-reddish quartzose hematitic untwinned dolomite. The white objects are distorted and brecciated corals of twinned and untwinned dolomite and quartz.

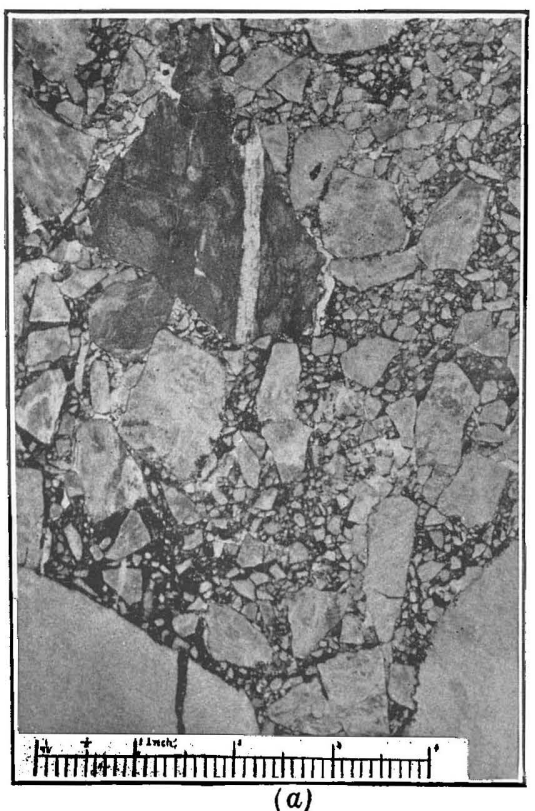

(a)

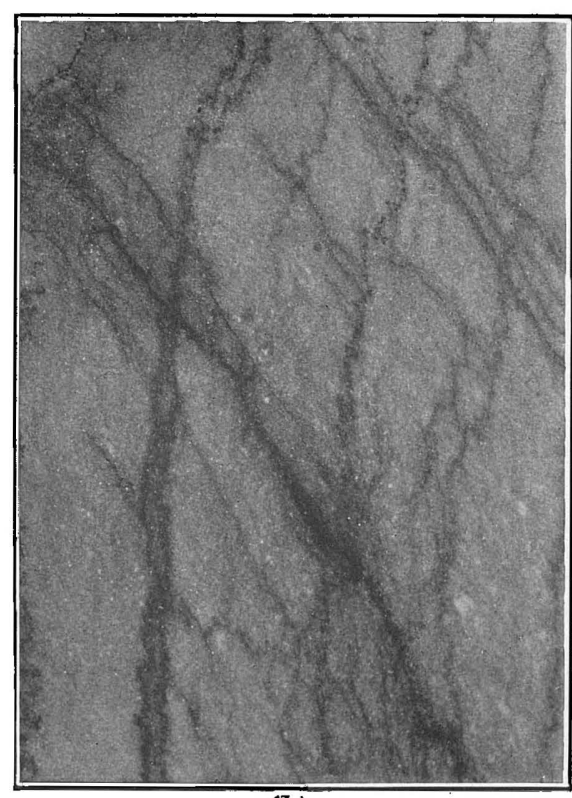

(b)

$B$.

a, POLISHED SPECIMEN OF BRECCIATED CALCITE AND DOLOMITE MARBLE FROM DYER QUARRY, MANCHESTER.

The cement is bright reddish and the fragments are bluish gray or cream-colored. The dark one with light vein is dull reddish brown.

b, SAWN SPECIMEN OF GRAPHITIC CALCITE MARBLE FROM ALBERTSON QUARRY, WEST RUTLAND.

Showing plicated bedding planes running lengthwise, crossed by planes of slip cleavage inclined to the right, both laden with graphite.

\section{POLISHED MARBLE SPECIMENS.}


general shape of some of them is good evidence of organic origin. Possibly some of the lenses were originally dolomite beds which alternated with ferruginous clayey beds but now lie brecciated in a hema. titic argillaceous matrix, and only the nucleated lenses are distorted dolomitized corals, but some of these are also clearly brecciated. Perkins ${ }^{1}$ reproduces a photograph of a slab of marble from Swanton filled with brachiopods (Salterella). A photograph of rough blocks of marble from Swanton is reproduced in Plate $\mathrm{V}, B$, and one of a polished piece with corals in Plate VIII, $A, c$.

These marbles are thus mainly magnetitic quartzose dolomites partly of sedimentary and partly of organic origin. The magnetite may have been originally deposited as a carbonate. In most of the beds the magnetite has become more or less oxidized into hematite, giving the marbles their reddish color. The corals have evidently been largely dolomitized and the central cavities, partly original and partly made by solution, have become filled with quartz from siliceous solutions. Whether this dolomitization took place in the sea or after emergence is uncertain. The marbles are thus the result of an interesting series of processes-sedimentation, both mechanical and organic, if not chemical also; dolomitization; metamorphism, accompanied by siliceous infiltration; brecciation; and underground oxidation.

The marbles of Swanton are very sonorous and, of course, harder than calcite marbles or even twinned dolomite marbles.

\section{MONKTON.}

The dolomite marble of Monkton occurs along the west foot of the Green Mountain range from Bristol to East Monkton, where it is in contact with the quartzite that forms the west side of the range. ${ }^{2}$ In its mottling this marble resembles slightly that of Swanton, but the ground is pink or pinkish and the blotches have a less regular form and are white or of a delicate rose color. On continued outdoor exposure these colors become more faint and on long weathering they disappear altogether and the rock either whitens or becomes dull greenish gray. In thin section the rock is seen to consist of dolomite plates and rhombs, mostly under 0.1 millimeter in diameter, and of more or less angular quartz grains up to 0.07 millimeter, with rarely one of feldspar (orthoclase and plagioclase), magnetite grains up to 0.005 millimeter, mostly altered to hematite, rare pyrite altered to limonite, a little sericite, and in places vein quartz.

The rock has fine beds or films of fibrous muscovite at short intervals. In thin section one of these, 1 to 2 millimeters thick, is seen to

1 Perkins, G. H., Sixth Rept. State Geologist Vermont, 1908, P1. XXXIX.

2 See Seely, H. M., Seventh Rept. State Geologist Vermont, 1910, p. 298, 
consist of minutely plicated sericite with many grains of magnetite; next and parallel to it runs a $\frac{1}{4}$-inch vein of quartz with calcite, dolomite, sericite, and magnetite.

The dolomite marble of Monkton is therefore also a hematitic quartzose dolomite, but with less hematite than the marble of Swanton, and is interbedded with fibrous muscovite. The hematite and the pinkish tint are derived by oxidation from the magnetite, as in the marbles of Swanton. The quartz and feldspar grains are of mechanical sedimentary origin, as was also the clay from which the fibrous muscovite was formed during metamorphism; vein quartz was deposited by siliceous waters at the same time.

The dolomite marble of Monkton is attractive on account of its very delicate color, but this color is not durable under outdoor exposure and the stone can be utilized only for indoor decoration.

\section{DOLOMITE MARBLES OF PROCTOR AND PITTSFORD.}

In the dolomite series which underlies the calcite marbles of the Otter Creek valley (see Pl. I and p. 66) a graphitic dolomite has recently been prospected for marble at a point about $1 \frac{3}{4}$ miles southwest of Pittsford village, in the township of Proctor (see p. 128), and found to take a good polish. This dolomite marble (specimen D, $\mathrm{XXXI}, 53, \mathrm{~b}$ ) is of bluish-black color and consists of greatly plicated, extremely fine black and white laminæ or beds not over 0.1 inch thick, suggesting a possible organic origin. ${ }^{1}$ Thin sections show it to be a dolomite of irregular plates from 0.02 to 0.25 millimeter in diameter, some of them twinned, and rare quartz grains. The white beds, from 0.12 to 0.25 millimeter thick, in places widen to lenses with vein quartz and dolomite plates up to 0.75 millimeter. The graphitic beds are from 0.12 to 0.5 millimeter thick. A medium bluish-gray dolomite near the graphitic beds is of similar character, but the darker bands are less graphitic. None of the sections show any conclusively organic texture.

From the now disused Whelden quarry at the Florence crossroads, $2 \frac{1}{2}$ miles northwest of Pittsford village, in Pittsford Township (see Pl. I), dolomite was shipped in 1900 to Bellows Falls for its magnesia, which is said to have been used in the manufacture of paper. The quarry is in a series of pink and cream-colored dolomites 40 feet thick. Some of the beds are ivory colored, others delicate rose, and others cream, spotted or banded with pink. In thin section these beds are seen to be slightly quartzose dolomites, with a grain diameter of 0.009 to 0.17 millimeter, averaging from 0.04 to 0.09 , with lenses of quartz and of twinned dolomite. They owe their tints to limonite or oxidized pyrite or to hematite from oxidized magnetite. There are

\footnotetext{
1 See Perkins, G. H., Fourth Rept. State Geologist Vermont, 1904, P1. LXXII (Stromatocerium lamottense Seely, which it somewhat resembles).
} 
small intercalated beds of sericite schist, quartz, and dolomite. The dolomite beds can be followed from this point for 2 miles along the strike.

This whole set of dolomite beds contains a variety of attractively colored fine-grained dolomite marbles, which but for the thinness of the beds and a possible tendency to fracture along intersecting fine quartz veins would possess economic value. Even as they are and quite irrespective of their colors these dolomites would serve well for mosaic flooring and terrazzo.

These pinkish and cream-colored dolomites, generally weathering light brown, form hillocks northeast and north-northeast of Brandon village and occur also in Chittenden, on Mount Chaffee, and form the summit and west side of the 2,547-foot hill south-southeast of that mountain, as shown on the map.

\section{UNMETAMORPHIC CALCITE MARBLE OF ISLE LA MOTTE.}

Although, as was explained on page 32 , the black marble of Isle la Motte contains a little dolomite, it is essentially calcite marble and mainly of organic origin, as shown by its abundant fossils and its carbon, but its calcite has crystallized without the aid of great compression and mainly as a result of chemical processes. The crinoids, gastropods, etc., still retain their forms, but their calcareous parts have been dissolved and redeposited as crystalline calcite and their internal cavities have also been filled with it or with the original fine

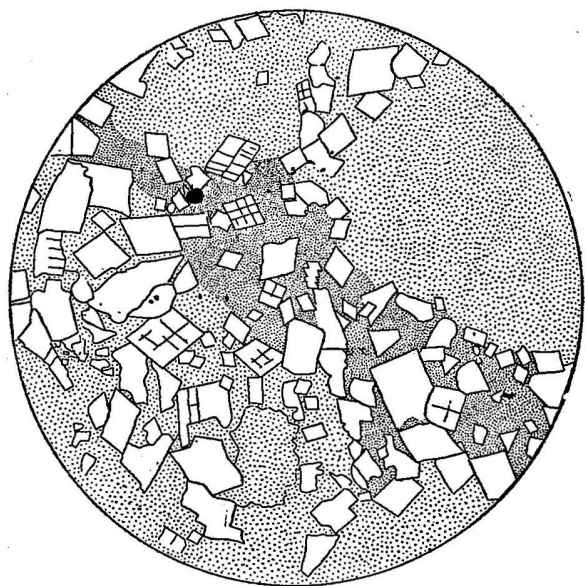

FrgURE 9.-Thin section of carbonaceous unmetamorphic calcite marble from Isle la Motte, showing dolomite crystals in groundmass of fine-grained, obscurely crystalline limestone. The darker parts are more carbonaceous; black particles are pyrite. calcareous sediment which has also been redeposited in crystalline condition. The geology of this marble has been described by Vermont geologists. ${ }^{1}$

The fresh rock has an extremely dark gray ("black"), finely crystalline surface, but it weathers a dark bluish gray, in places with fine brownish-gray streaks parallel to the bedding. A typical thin section

1 Hitchcock, Edward, and Hager, A. D., Geology of Vermont, vol. 2, 1861, pp. 776-778. Brainerd, Ezra, The Chazy formation in the Champlain Valley: Bull. Geol. Soc. America, vol. 2, 1891, pp. 297-298. Perkins, G. H., First Rept. State Geologist, 1898, pp. 40-42; Second Rept., 1900, p. 31; Sixth Rept., 1908, pp. 22-23, Pl. VI. 
of it is shown in figure 9. In some thin sections it consists of small irregular, finely granular but crystalline masses in a matrix of coarse and crystalline particles of calcite throughout which dolomite rhombs are more or less thickly disseminated. In others it consists of irregular bands of dolomite in rhombs measuring from 0.025 to 0.1 millimeter, alternating with bands of fossiliferous granular limestone in which most of the grains are crystalline untwinned calcite. There are some dolomite rhombs, however, both in the fossils and in the granular calcite. Some dolomite rhombs occur in the central tubes of crinoid stems which are twinned dolomite or calcite, probably the latter. The rock contains a few grains of quartz, carbonaceous particles, and spherules of pyrite oxidizing to limonite.

A bed of very dark brownish crinoid limestone shows in thin section crinoids and other fossils changed to twinned calcite lying in a matrix of extremely fine grained, in places pyritiferous material containing dolomite rhombs. Some of the dolomite rhombs lie in meandering fractures and carbonaceous streaks within plates of calcite.

An analysis of the marble from Isle la Motte by Olmstead, published by Hager ${ }^{1}$ in 1858, shows a small percentage of magnesium carbonate.

$$
\text { Analysis of "Isle la Motte black marble." }
$$

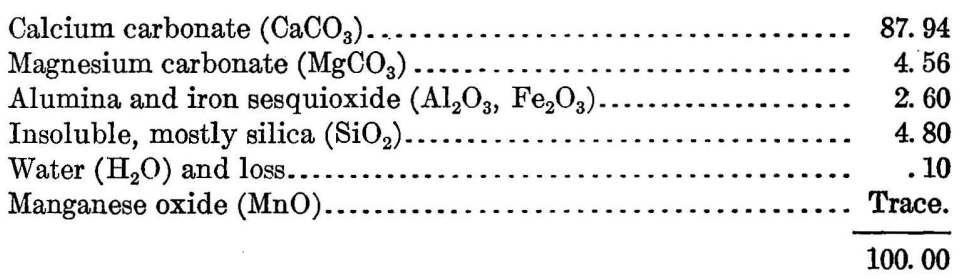

"MANCHESTER BRECCIA."

A "breccia" is a rock which has been more or less crushed by crustal movement but the particles of which have been recemented together by minerals deposited by percolating solutions. A breccia can always be distinguished from a rock made up of waterworn pebbles by the angularity of its particles. Breccias from the very mode of their origin are weak, and even when used for decorative purposes usually have to be fortified by cementing them at the back to slabs of solid marble or slate. Some of the most attractive imported marbles are breccias from Italy and North Africa.

Aside from the dolomite and calcite marble breccia on the west side of Pine Hill, in Proctor (p. 31), and an outcrop in Sudbury (p. 139), the only marble breccia yet known in Vermont is that in Manchester, 2 miles S. $10^{\circ}$ E. from the top of Mount Equinox. (See p. 97 and Pl. I.) 
A photograph of a polished specimen of this marble breccia is reproduced in Plate VIII, $B, a$. The cement is brick-red and the fragments, of very unequal size, are of three sorts-(1) a light-pinkish or cream-colored calcite marble with a grain diameter from 0.05 to 0.37 millimeter and the long axes of the grains parallel, containing a little sericite and some quartz grains; (2) a deep-reddish hematitic dolomite marble, containing some calcite, with a grain diameter averaging roughly 0.09 millimeter, some of the particles veined with quartz; and (3) a light bluish-gray calcite marble with a grain diameter from 0.12 to 0.5 millimeter. The cement owes its brightred color to hematite stain proceeding from particles of magnetite. It contains many very minute particles of the three kinds of marble in the breccia, and calcite plates, quartz grains, up to 0.2 millimeter, and rarely a feldspar grain (microcline). It owes its cementing property to calcite and hematite.

The rock takes a good polish but like other breccias needs to be fortified. Some of the fragments in it are so large as to deprive the rock of that degree of uniformity which would make it all of commercial value.

\section{SERPENTINE OF ROXBURY.}

The serpentine of Roxbury ${ }^{1}$ is a marble only in a commercial sense. Roxbury, is on the east side of the Green Mountain axis, in Washington County, 14 miles southwest of Montpelier. The quarry is about half a mile south of the station, on the east side of a northsouth ridge. The serpentine there is 50 to 60 feet wide, dips $45^{\circ}-65^{\circ}$ roughly west, and is reported to continue for several miles in a northnorthwest to south-southeast direction, with varying width but in places tapering out altogether. It is in contact on the east with a schist whose foliation strikes N. $15^{\circ}-20^{\circ} \mathrm{W}$. and dips from $65^{\circ} \mathrm{N}$. $73^{\circ} \mathrm{E}$. to vertical, and on the west with a similar schist whose foliation has about the same strike but dips $65^{\circ}-70^{\circ} \mathrm{W}$. These rocks, in thin sections, are found to be chlorite or chloritized biotito schist with epidote, calcite, and rarely muscovite, also tremolite schist with chlorite. The tremolite schist is on the west side. These schists may be altered eruptives. Their poverty in quartz is significant.

Dark-colored serpentine is a hydrous silicate of magnesia and iron. Some serpentines are of metamorphic sedimentary origin; others are metamorphosed eruptive rocks, and to this class that of Roxbury probably belongs. The nature of the original dike rock is uncertain. It may easily have been peridotite, which has a large content of

\footnotetext{
1 See Hitchcock, Edward, and Hager, A. D., Geology of Vermont, 1861, vol. 1, p. 543; vol. 2, p. 780; also the following reports of the State geologist: First, 1898, pp. 37, 38; Second, 1900, p. 56; Third, 1902, pp. 89, 90; Fifth, 1906 (Marsters, Origin of serpentine), pp. 53-61; Sixth, 1908, p. 31; Seventh, 1910 (Rich. ardson, Serpentine), pp. 318, 310.
} $49311^{\circ}-$ Bull. $521-12-4$ 
magnesia and iron oxides. The serpentine in thin section shows a fibrous and radial texture with veinlets of magnesite and talc and with large particles of magnetite, which also appear on the polished face. The rock is of dark purplish or greenish color in the mass and is plentifully veined with white magnesite. Polished faces are almost black but crossed by a network of veins and veinlets of white and of light green wherever the magnesite is mingled with the serpentine. As many of these veins are faulted and sheared, the rock has evidently since its alteration to serpentine been subjected to compression. These sheared veins in thin sections show alternating blades of magnesite and foliated serpentine bent at right angles to the direction of the vein, forming "shear zones" like those in slates.

It is uncertain when the rocks on either side of the serpentine acquired their schistosity. Some of their minerals probably originated in emanations from the dike material, now serpentine, and are due to the heat accompanying the intrusion.

The serpentine of Roxbury takes a fairly good polish and its striking contrasts of shade and color and the irregularity of its veining make it a very attractive ornamental stone for interior work. (See Pl. VIII, $A, a$.)

\section{CHROME MICA SCHIST OF SHREWSBURY.}

The newly discovered green "marble" of Shrewsbury is a chrome mica schist and is included among marbles for commercial reasons only. It occurs in a small saddle on the north side of Round Hill, on the west flank of the Green Mountain range, $3 \frac{3}{4}$ miles southeast of the Rutland station and about 900 feet above it, in the northwestern part of Shrewsbury Township. The schist, which is about 100 feet thick, strikes $\mathrm{N} .15^{\circ}-30^{\circ}$ W., dips steeply east, and probably belongs in the Lower Cambrian schist. The discoverer and prospective operator is Edward H. Foley, 147 South Main Street, Rutland, Vt.

The schist (specimen D, XXXI, 87, a, rough; b, polished) in the rough has a bright verdigris-green to faintly greenish gray color. Its luster ranges from glistening to waxy and its texture is foliaceous and plicated. The polished stone has a brilliant dark emerald-green color varied with fine streaks, more or less plicated, of lighter green. It resembles talc in places but is considerably harder. J. S. Diller and W. T. Schaller, of this Survey, find that it consists largely of chrome mica (fuchsite) with some chlorite, quartz, and tourmaline, and the writer finds also magnetite present. ${ }^{1}$

1 Fuchsite is briefly described in E. S. Dana's Descriptive mineralogy, 6th ed., 1892, p. 616. It was first described by Schafhäutl, who examined some from Schwarzenstein, in the Zillerthal, Tyrol, and gave its composition as follows: $\mathrm{SiO}_{2}, 47.95 ; \mathrm{Al}_{2} \mathrm{O}_{3}, 34.45 ; \mathrm{Fe}_{2} \mathrm{O}_{3}, 1.80 ; \mathrm{MgO}, 0.72 ; \mathrm{K}_{2} \mathrm{O} ; 10.75 ; \mathrm{F}, 0.35 ; \mathrm{Cr}_{2} \mathrm{O}_{3}, 3.95$; $\mathrm{Na}_{2} \mathrm{O}, 0.37$; $\mathrm{Ca}, 0.42$; total, 100.76. Its content of chrome sesquioxide, to which it owes its brilliant color, is thus only 3.95 per cent. Schafhäutl, in 1843, described another chrome mica with 5.91 per cent of $\mathrm{Cr}_{2} \mathrm{O}_{3}$. For analysis of a fuchsite from Montgomery County, Md., by T. M. Chatard, see Bull. U. S. Geol. Survey No. 419,1910 , p. 286, analysis J. This specimen contained only 2.03 per cent of $\mathrm{Cr}_{2} \mathrm{O}_{3}$. 
The brilliant green color and high polish of this stone make it very suitable for internal decoration. Its commercial value will depend on the size and soundness of the blocks obtainable.

The fuchsite schist is cut by a 5 -foot dike of rhyolite porphyry, somewhat micasized and kaolinized, of light-grayish color at the surface and stained with limonite. On the west side of the schist is a quartz vein with a little pyrrhotite (magnetic iron pyrites).

\section{MICROSCOPIC TEXTURE OF THE CALCITE MARBLES.}

GRAIN FORM.

The grains of calcite in calcite marble never show crystallographic outlines. Their forms are altogether irregular, being bounded, as seen in cross section, by irregular curves or straight lines making reentrant or projecting angles which are usually obtuse. Only where calcite and dolomite grains are mixed do the calcite grains appear to have jagged or denticulate outlines. The grain form in some of the typical Vermont marbles is shown in figures 13,15, 16, 21, and 24, pages 99, 108, 119, 134, 140.

In beds which have suffered much compression the grains are very perceptibly elongated in at least one direction and probably in two. This is shown in figures 6 and 22 (pp. 41 and 136). This grain elongation characterizes the muscovitic marbles on both sides of the West Rutland anticline. The effect is to give a degree of schistosity to the marble, so that it breaks more readily along the bedding plane.

As has already been explained (p. 32) the clouded marbles are marked by fine passages or lenses of untwinned grains of dolomite marble which are in general not only very much smaller in diameter than the calcite but of more regular outline and here and there of crystallographic (rhombic) form. The marbles of the Clarendon Valley, Landon, and Hollister quarries show this feature. (See pp. 110, 133, 135.)

\section{GRAIN DIAMETER.}

In measuring the diameters of the grains in thin sections for this bulletin the method followed has been first to measure the smallest and the largest particle, then to note the general maximum and minimum diameter. The actual minimum differs far less in most of the marbles than the maximum, so that an average based on it is misleading. In a few of the more even-grained marbles the average grain diameter has been obtained by the Rosiwal method. This average appears to be always less than the average of the general maximum and minimum estimated with the micrometer.

The most noticeable fact as to the grain diameter of Vermont marbles is the coarseness of some and the fineness of others. The 
Danby and Dorset constructional marbles (Dorset Mountain and Green Peak types) have a grain diameter from 0.05 to 1.5 millimeters, mostly 0.12 to 0.5 , and an average diameter from 0.20 to 0.24 millimeter, or 0.005 inch. At the other extreme the statuary marble of both sides of the West Rutland anticline and at the Goodell quarry, in Brandon, has a grain diameter of 0.02 to 0.5 millimeter, mostly 0.07 to 0.16 , averaging 0.1 millimeter or about 0.0025 inch. Furthermore, about half a mile southeast of the village of Sudbury, about $5 \frac{1}{2}$ miles west of Brandon, is an outcrop of light bluish gray calcite marble, probably of no commercial value, in which the grain diameter ranges from 0.02 to 0.2 millimeter, mostly from 0.05 to 0.1 , averaging probably about 0.05 millimeter, or 0.0013 inch-that is, about half the grain diameter of the statuary "Rutland."

The other marbles fall naturally into two intermediate groupsone of finer grain, comprising marbles like those of Middlebury and Brandon, the "second statuary" of West Rutland, and bed F (cream) of the Eastman quarry, having extremes of 0.02 to 0.75 millimeter, mostly 0.1 to 0.25 , and averaging about 0.12 millimeter, or 0.003 inch; and one of coarser grain, comprising marbles like those of the True Blue, Shangrow, and several of the beds of the Eastman quarry, with grain diameters from 0.12 to 0.75 millimeter, mostly 0.12 to 0.37 , and some of the beds of the Hollister quarry and the Pittsford and Brandon "Italian" marbles, with grain diameters of 0.05 to 1 millimeter, mostly 0.12 to 0.5 . These coarser marbles together range mostly from 0.12 to 0.31 and average 0.15 millimeter, or 0.004 inch.

Another noticeable textural feature is the great variation in regularity or evenness. The "True Blue" and "statuary Rutland" are even textured, but the "mahogany bed" of the Freedley quarry on Dorset Mountain, the "Pittsford Italian," the "Brandon Italian," and the "Clarendon" are uneven. The most irregular in grain diameter is the fossiliferous graphitic marble of the Day lime quarry, in Ira, which has a range from 0.02 to 2 millimeters. This subject will be further considered under the next heading.

\section{GRAIN ARRANGEMENT.}

As shown in the drawings (figs. 13, 15, 16, 21, and 24, pp. 99, 108, 119, 134, and 140), many of the marbles show no arrangement of their particles. This absence of arrangement is as characteristic as the irregularity of grain form.

Where the grains are elongated there is generally a parallelism between the long axes of the different grains, and it is this arrangement which imparts a slight schistosity, to the marble. This parallelism characterizes many of the muscovitic marble beds but is not confined to them. (See figs. 6 and 22, pp. 41 and 136.) 
The marble quarried for lime at Leicester Junction consists of fine and coarse grains in alternate parallel bands averaging about 0.05 millimeter in width. The larger grains are from 0.04 to 0.09 millimeter long and the smaller ones 0.009 to 0.03 millimeter in diameter. (See fig. 25, p. 148.)

On the other hand, the marble of the "mahogany bed" at the Freedley quarry, on Dorset Mountain (p. 106), consists of large plates measuring 0.02 to 1.25 millimeters, mixed with small ones of 0.07 to 0.25 millimeter, without any arrangement whatever. The same irregularity of size but not of arrangement appears in the section of "Brandon Italian" shown in figure 22 (p. 136).

In the clouded marbles (Hollister, Landon, Florence No. 2, etc.), which contain lenses and little plicated beds of dolomite grains in a mass of calcite grains, and also in some of the banded graphitic marbles (Clarendon) the grain arrangement is chemical and stratigraphic.

The arrangement of grains is affected not only wherever the beds have been elongated in folding but also at the intersections of plicated beds and planes of slip cleavage, as in the marble of the Albertson quarry (Pl. VIII, $B, b$ ).

\section{COMPARISON WITH EUROPEAN MARBLES.}

Vogt ${ }^{1}$ classifies Norwegian and European marbles in six textural groups, as follows:

1. Entirely compact (extra fine grained), with a grain diameter of mostly 0.02 to 0.03 millimeter (Värra, near Trondhjem), and almost entirely compact, 0.03 to 0.06 millimeter (Carrara "white $\mathrm{P}$ ").

- 2. Very fine grained, 0.1 to 0.3 millimeter (Carrara, ordinary).

3. Moderately fine grained, 0.25 to 0.75 millimeter (Carrara, statuary).

4. Slightly coarse, 0.75 to 1 millimeter.

5. Moderately coarse, 1 to 3 millimeters (most of the Norwegian marbles).

6. Very coarse, 2 to 5 millimeters.

In comparing Vermont marbles with this classification the "statuary Rutland" and "second statuary Rutland" belong in group 2; the Florence No. 2, "light Rutland Italian," "brocadillo," "Pittsford Italian," and some of the beds of the Hollister quarry belong in group 3; and the "Dorset" and "Danby" marbles belong in group 5.

1 Vogt, J. H. L., Der Marmor: Zeitschr. prakt. Geologie, 1898, p. 12. 
The measurements of ancient Greek marbles made by Lepsius (pp. 26, 27) are here summarized and referred to Vogt's scale:

Classification of ancient Greek marbles according to grain diameter.

\begin{tabular}{|c|c|c|c|}
\hline . & \multicolumn{2}{|c|}{$\begin{array}{l}\text { Diameter in milli- } \\
\text { meters. }\end{array}$} & \multirow{2}{*}{$\begin{array}{l}\text { Scale } \\
\text { No. }\end{array}$} \\
\hline & Average. & Maximum. & \\
\hline 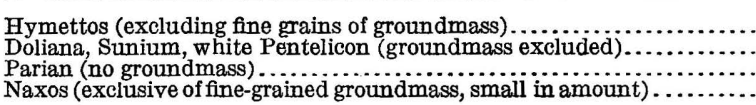 & $\begin{array}{r}\text { Under } 0.5 \\
0.5-1 \\
1-1.5 \\
2-4\end{array}$ & $\begin{array}{r}0.8 \\
2-4 \\
5 \\
8\end{array}$ & $\begin{array}{l}3 \\
4 \\
5 \\
6\end{array}$ \\
\hline
\end{tabular}

\section{GRADES OF TEXTURE.}

In grading the marbles of western Vermont by texture alone the simplest system appears to be to divide them into five grades defined by the maximum grain diameter in connection with the average grain diameter, and to refer each grade to a well-known type or types. To these five grades a sixth has been added in the table below to cover a very coarse Massachusetts marble, which has also been found in eastern Vermont.

Classification of Vermont marbles by grades of texture.

\begin{tabular}{|c|c|c|c|c|c|}
\hline \multirow{3}{*}{ Grade. } & \multicolumn{4}{|c|}{ Grain diameter. } & \multirow{3}{*}{ Grade types. } \\
\hline & \multirow{2}{*}{$\begin{array}{l}\text { Maxi- } \\
\text { mum } \\
\text { (milli- } \\
\text { meter). }\end{array}$} & \multirow{2}{*}{$\begin{array}{l}\text { Average } \\
\text { (milli- } \\
\text { meter). }\end{array}$} & \multicolumn{2}{|c|}{$\begin{array}{l}\text { General aver- } \\
\text { age. }\end{array}$} & \\
\hline & & & $\begin{array}{l}\text { Milli- } \\
\text { meter. }\end{array}$ & Inch. & \\
\hline 1. Extra fine... & 0.2 & $0.05-0.10$ & 0.06 & 0.0023 & $\begin{array}{l}\text { Dolomite marbles of Swanton, Sudbury out- } \\
\text { crop of calcite marble, dolomitic lenses in } \\
\text { mottled calcite marbles. }\end{array}$ \\
\hline 2. Very fine.. & .5 & $.07-.16$ & .10 & .0039 & "Statuary Rutland," Goodell quarry, Bran- \\
\hline 3. Fine...... & .75 & $.10-.25$ & .12 & .0047 & "Second statuary Rutland," bed IJ of East- \\
\hline 4. Medium. & 1.0 & $.12-.31$ & .15 & .0059 & $\begin{array}{l}\text { man quarry. } \\
\text { "Brandon Italian," "True Blue," bed } \mathrm{K} \text { of } \\
\text { Hollister quarry, excluding dolomite }\end{array}$ \\
\hline 5. Coarse..... & 1.5 & $.20-.60$ & .24 & .0094 & "Dorset A," "White Stone Brook," Dorset \\
\hline 6. Extra coarse....... & 2.54 & $.30-1.35$ & .50 & .0196 & Adams, Mass., and eastern Vermont. \\
\hline
\end{tabular}

In this scheme the Parian statuary (p. 26) would belong in grade 6, the modern commercial Pentelicon (p. 25) in grade 3, and the Carrara ordinary (p. 53), the Laas statuary (Tyrol), and the dolomite marbles of Lee and Ashley Falls, Mass., in grade 4. 


\section{LITERATURE OF MARBLE.}

\section{SCIENTIFIC BIBLIOGRAPHY.}

The following list includes the more important scientific works on the nature and origin of marble:

Adams, F. D., and Coker, E. G., Experimental investigation of the compressibility and plastic deformation of certain rocks (abstract): Bull. Geol. Soc. America, vol. 16, 1905, pp. 564-565.

Adams, F. D., assisted by Coker, E. G., An experimental investigation into the flow of rocks-The flow of marble: Am. Jour. Sci., 4th ser., vol. 29, 1910, pp. 465-487, Pls. II-IV.

Adams, F. D., and Nicholson, J. T., An experimental investigation into the flow of marble: Phil. Trans. Royal Soc. London, vol. 195, pt. A, 1901, pp. 363-401, Pls. XXII-XXV. Abstract, Am. Jour. Sci., 4th ser., vol. 10, 1900, pp. 401-403.

BartLETT, W. C., Experiments on the expansion and contraction of building stones by variation of temperature: Am. Jour. Sci., 1st ser., vol. 22, 1832, pp. 136-140.

Becker, Arthur, Ueber die Schmelzbarkeit des kohlensauren Kalkes: Min. pet. Mitt., Neue Folge, vol. 7, 1886, pp. 122-145.

Clarke, F. W., Analyses of rocks and minerals from the laboratory of the United States Geological Survey, 1880-1908: Bull. U. S. Geol. Survey No. 419, 1910. Analyses by Eakins, Steiger, and Schneider on p. 189.

- The data of geochemistry, 2d ed.: Bull. U. S. Geol. Survey No. 491, 1911, pp. 117-119, 396, 534-544, 593-596.

Croor, T., On dedolomitization: Geol. Mag., London, dec. 5, vol. 8, 1911, pp. 339445.

Delépine, G., Recherches sur le calcaire carbonifère de la Belgique, Paris, 1911.

Dewey, Chester, Notice of the flexible or elastic marble of Berkshire County: Am. Jour. Sci., 1st ser., vol. 9, 1825, p. 241.

Dieulafait, —- Existence du manganèse à l'état de diffusion complète dans les marbres bleus de Carrare, de Paros et des Pyrénées: Compt. Rend., vol. 98, 1884, pp. 589-591.

- Manganèse dans les marbres cipolins de la formation primordiale; Conséquences géologiques: Compt. Rend., vol. 98, 1884, pp. 634-636.

DILLER, J. S., The educational series of rock specimens collected and distributed by the United States Geological Survey: Bull. U. S. Geol. Survey No. 150, 1898, pp. 299-301, Pl. XL.

Egenter, PAUL, Die Marmorlagerstätten Kärntens [Carinthia]: Zeitschr. prakt. Geologie, vol. 17, 1909, pp. 419-439, Pl. V.

Geikie, ARChIBALd, Rock-weathering as illustrated in Edinburgh churchyards: Proc. Royal Soc. Edinburgh, vol. 10, 1880, pp. 518-532, P1. XVI.

- Geological sketches at home and abroad, London, 1882, pp. 159-179. On rock-weathering measured by the decay of tombstones.

— Textbook of geology, 4th ed., 1903, vol. 1, p. 402; vol. 2, p. 772.

Giampaou, A., I marmi di Carrara, Pisa, 1897.

Grubenmann, U., Die Kristallinen Schiefer, 2d ed., Berlin, 1910, pp. 269-275, Pl. XII, figs. 5,6 .

HALL, JAMES, Account of a series of experiments, showing the effects of compression in modifying the action of heat: Trans. Royal Soc. Edinburgh, vol. 6, 1812, pp.71185, Pls. 1-5.

HARKer, Alfred, Petrology for students, an introduction to the study of rocks under the microscope, 4th ed., Cambridge, 1908, pp. 253-276, 305-309, 327.

HATCH, F. H., Dedolomitization in the marble of Port Shepstone (Natal): Quart. Jour. Geol. Soc. London, vol. 66, 1910, pp. 507-522. 
HoffmaNn, L., Die Marmorlager von Auerbach an der Bergstrasse in geologischer, mineralogischer und technischer Beziehung. Abhandl. Grossherzogl. hessischen geolog. Landesanstalt, Darmstadt, vol. 2, pt. 3, 1894, pp. 117-161. Abstract in Zeitschr. prakt. Geologie, 1896, pp. 353-364, with diagrams, etc., not in original.

InostranzeFF, — von, Untersuchung von Kalksteinen und Dolomiten: Jahrb. K.-k. geol. Reichsanstalt, Tschermaks min. Mitt., vol. 22, 1872, pp. 45-51, figs. 6-11, Pl. III.

Kemp, J. F., Handbook of rocks for use without the microscope, 4th ed., New York, 1908, pp. 138-140.

Le Chatelier, H., Sur la fusion du carbonate de chaux: Compt. Rend., vol. 115, 1892, pp. 817-820,.1009-1011.

Lepsius, G. R., Griechische Marmorstudien: Anhang Abhandl. K. Akad. Wiss. Berlin, 1890.

- Geologie von Attika-ein Beitrag zur Lehre vom Metamorphismus der Gesteine, Berlin, 1893.

LindenmanN, BeRnHARD, Ueber einige wichtige Vorkommnisse von körnigen Carbonatgesteinen mit besonderer Berücksichtigung ihrer Enstehung und Structur: Neues Jahrb., Beilage Band 19, 1904, pp. 197-317, Pls. XI-XIII.

MerRILL, G. P., Handbook for the department of geology in the United States National Museum: Rept. U. S. Nat. Mus., 1890, pp. 544-546, fig. 93.

- A treatise on rocks, rock weathering, and soils, New York, 1906, pp. 141, 142, fig. 14.

Oschatz, — [Note on the microscopic texture of marble]: Zeitschr. Deutsch. geol. Gesell., vol. 7, 1855, pp. 5, 6 .

Renard, A. F., Des caractères distinctifs de la dolomite et de la calcite dans les roches calcaires et dolomitiques du calcaire carbonifère de Belgique: Bull. Acad. roy. Belgique, vol. 47,1879 , pp. 541-563, figs. 1, 2.

Rosenbusch, H., Elemente der Gesteinslehre, 3d ed., Stuttgart, 1910, pp. 518-521, $527-530,533$, figs. 77,78 .

VоGт, J. H. L., Norsk Marmor: Norges geol. undersøgelse, No. 22, Christiania, 1897; summary in German on pp. 334-364.

- Der Marmor in Bezug auf seine Geologie, Structur und seine mechanischen Eigenschaften: Zeitschr. prakt. Geologie, 1898, pp. 4-16, 43-52.

Winslow, A., An illustration of the flexibility of limestone [white marble]: Am. Jour. Sci., 3d ser., vol. 43, 1892, pp. 133-134.

Wirtstein, G. C., Untersuchung einiger weisser Marmorarten: Buchners Repert. Pharmacie, 1851. Abstract in Neues Jahrb., 1851, pp. 444-445.

Yamagawa, Kenjro, Determination of the thermal conductivity of marble: Jour. Coll. Sci. Imp. Univ. Japan, vol. 2, 1888. Review in Neues Jahrb., 1892, vol. 2, p. 43.

ZACCAGNA, D., Una escursione nella regione marmifera del Carrarese: Boll. R. comitato geol. d'Italia, Rome, 1881, vol. 12, pp. 476-501.

Zirked, Ferdinand, Lehrbuch der Petrographie, 2d ed., vol. 3, 1894, pp. 445-511.

\section{ECONOMIC BIBLIOGRAPHY.}

The following list includes tho more important works of an economic character on marble.

(Anonymous) The marbles of Greece used in the United States: Stone, vol. 29, 1908, pp. 301-303.

(Anonymous) Marble in Newfoundland: The Quarry, March, 1912, p. 76.

(Anonymous) Marbles of California: Bull. California State Min. Bur. No. 38, 1906, pp. 95-114. 
Baker, R. T., Building and ornamental stones of New South Wales, 2d ed., Technological Museum, Sydney, 1909. Marbles, Pls. I, XIII-XXXVI.

Bцock, J., Die Tiroler Marmor-Lager: Sitzungsb. Niederrhein. Gesell. Natur- u. Heilkunde, Bonn, 1906, pp. 77-82.

Böнме, - Untersuchungen von natürlichen Gesteinen: Mitt. Kgl. Versuchsanstalten, 2te Ergänzungsheft, Berlin, 1889.

BRINDlex, W., Marble: The Quarry, vol. 4, 1899, pp. 526-528.

Brinsmade, R. B., Marble quarrying of Gouverneur, N. Y.: Eng. and Min. Jour.. vol. 80, 1905, pp. 728-730.

BuckLey, ERNest R., Building and ornamental stones of Wisconsin, 1898, pp. 413, 414.

Burniam, S. M., History and uses of limestone and marbles, Boston, 1883.

Butts, Charles, Variegated marble southeast of Calera, Shelby County, Ala.: Bull. U. S. Geol. Survey No. 470, 1911, pp. 237-239.

Byrne, P., Marble formations of the Cahaba River, Alabama: Eng. and Min. Jour., vol. 72, 1901, p. 400; Trans. Eng. Assoc. South, vol. 12, 1902, pp. 48-59.

Crark, W. B., and Mathews, E. B., Report on the physical features of Maryland, together with an account of the exhibits of Maryland mineral resources made by the Maryland Geological Survey: Maryland Geol. Survey Special Pub., vol. 6, pts. 1 and 2, Baltimore, 1906.

Clute, F. P., History of the marble industry in Tennessee: Fifth Ann. Rept. Bureau of Labor, Statistics and Mines, Nashville, 1896.

Darton, N. H., Staunton folio (No. 14), Geol. Atlas U. S., U. S. Geol. Survey, 1894. Marble of White Pine County, Nev., near Gandy, Utah: Bull. U. S. Geol. Survey No. 340, 1908, pp. 377-380.

Day, Allen Wriley, The marble quarries of Carrara: Sci. Am., Nov. 16, 1907, p. 361.

Eckel, Edwin C., Building stones and clays: their origin, characters, and examination, 1912. Marbles, pp. 166-181.

Eglestone, Thomas, The cause and prevention of the decay of building stone: Trans. Am. Soc. Civ. Eng., vol. 15, 1886.

Gordon, C. H., The marbles of Tennessee: Bull. Tennessee Geol. Survey No. 2D, 1911.

Hawes, G. W. [Limestones and marbles]: Tenth Census U. S., vol. 10, 1884, pp. 27, 28, Pl. XVII.

HerRmanN, O., Steinbruch-industrie und Steinbruch-geologie, Berlin, 1899.

HrRschwald, J., Die Prüfung der natürlichen Bausteine auf ihre Wetterbeständigkeit, Berlin, 1908. Abstract in Zeitschr. prakt. Geologie, July-Nov., 1908.

—_ Bautechnische Gesteins-untersuchungen: Mitt. mineral.-geol. Inst. Techn. Hochschule, Berlin, 1910, pp. 1-24, figs. 10-13.

Hopkins, Thomas C., Marbles and other limestones: Ann. Rept.. Geol. Survey Arkansas, vol. 4, 1893, Chapters I, II, XII, XIII, XIV, XV, XXVII, XXVIII, pp. 159-160.

Hull, Edward, A treatise on the building and ornamental stones of Great Britain and foreign countries, 1872.

Humphrey, R. L., The fire-resistive properties of various building materials: Bull. U. S. Geol. Survey No. 370, 1909, pp. 69-74.

JAckson, A. W., Building stones [of California]: Seventh Ann. Rept. California State Mineralogist, 1888, pp. 212, 213.

Julien, Alexis A., The durability of building stones: Tenth Census U. S., vol. 10, 1884, pp. 366-367, 659 .

The decay of the building stones of New York City: Trans. New York Acad. Sci., vol. 2, 1882-1883, pp. 67-79, 120-138.

- Building stones, elements of strength in their constitution and structure: Jour. Franklin Inst. vol. 147, 1899, pp. 258-286, 378-397, 430-442. 
Keith, Arthur, Tennessee marbles: Bull. U. S. Geol. Survey No. 213, 1902, pp. $366-370$.

Kosmann, B., Die Marmorarten des deutschen Reichs, Berlin, 1888.

Lee, Arthur, Marble and marble workers, 1887.

McCalley, Henry, The Coosa Valley region: Report on valley regions of Alabama, pt. 2, Alabama Geol. Survey, 1897.

McCaluie, S. W., A preliminary report on the marbles of Georgia: Bull. Geol. Survey Georgia No. 1, 1894.

Merrilu, George P., Stones for building and decoration, 3d ed., 1908, pp. 203-240, 324-340.

Merrill, George P., and Mathews, Edward B., The building and decorative stones of Maryland, containing an account of their properties and distribution: Maryland Geol. Survey, vol. 2, pt. 2, 1898, pp. 99-119, 171-193.

Newland, David H., The mining and quarry industry of New York State: Bull. New York State Mus. No. 93, 1905; No. 120, 1908; No. 152, 1909.

Paige, Sidney, Marble prospects in the Chiricahua Mountains, Arizona: Bull. U. S. Geol. Survey No. 380, 1909, pp. 299-311.

Parks, W. A., The building and ornamental stones of Ontario: Official Rept. Mines Branch, Ontario, 1911. Marble, pp. 74-76. Abstract in The Quarry, March, 1912, p. 75.

Pratt, Joseph Hyde, Marble and talc of North Carolina: Stone, vol. 24, 1902, pp. 145-149.

RAthbun, J. C., Marble in the Northwest: Min. World, vol. 24, 1906, p. 441.

Renwick, W. G., Marble and marble working, a handbook for architects, sculptors, marble quarry owners and workers, and all engaged in the building and decorative industries, London, 1909.

Ries, HeInrich, Economic geology, with special reference to the United States, 3d ed., 1910, pp. 113-114.

RINNE, F., Vergleichende Untersuchungen über die Methoden zur Bestimmung der Druckfestigkeit von Gesteinen, No. 2: Neues Jahrb., 1907, vol. 1, pt. 2, pp. 45-61, Pls. VI-VIII; 1909, vol. 2, pp. 121-128.

- Praktische Gesteinskunde, Hanover, 1905.

Schmid, H., Die modernen Marmore und Alabaster, Leipzig and Vienna, 1897.

- Der pentelische Marmor: Der deutsche Steinbildhauer und Steinmetz, vol. 14, No. 5, 1898. Includes a comparison of Carrara with Laas statuary.

SEIPP, H., Italienische Materialstudien: Forschungen und Gedanken über Bau und Dekorationsteine Italiens, für Kunstforscher, Kunstfreunde, Studierende, Architekten sowie für Steinindustrielle, Stuttgart, 1911. Weathering of marbles, pp. 23-35, 62-70, 117-153; explanation of effect of polishing, pp. 76-105; theory of effect of frost on building stones, pp. 211-228.

ShedD, S., The building and ornamental stones of Washington: Ann. Rept. Washington Geol. Survey, vol. 2, 1903.

Sмчтн, C. H., JR., Report on a preliminary examination of the general and economic geology of four townships in St. Lawrence and Jefferson counties, N. Y.: Ann. Rept. New York State Mus., vol. 47, 1894, pp. 687-709.

Southern RaIlway, Tennessee marble industry, No. 5, vol. 11, 1906.

SpeEr, F. W., Quarry methods, marble: Tenth Census U. S., vol. 10, 1884, p. 42.

SteinhäUser, - Der Tiroler Marmor und seine Eigenschaften in technischer Beziehung: Verhandl. K.-k. geol. Reichsanstalt, 1870, pp. 207-209.

TARR, RALPH S., Economic geology of the United States, with briefer mention of foreign mineral products, 2 d ed., 1895.

Webb, Percy C., A titanic blast [at Carrara]: Stone, vol. 29, No. 5, 1908, pp. 204-206.

Weinschenk, E., Die Tiroler Marmorlager: Zeitschr. prakt. Geologie, vol. 11. 1903. pp. 131-147. 
Wruss, Barter, The marbles of Hawkins County, Tennessee. School of Mines Quarterly, N. Y.: vol. 9, 1888, pp. 112-123.

Wright, Charles W., The building stones and materials of southeastern Alaska: Bull. U. S. Geol. Survey No. 345, 1908, pp. 116-126.

\section{PUBLICATIONS ON VERMONT MARBLES.}

The following list comprises the more important papers on the marbles of Vermont:

Adams, C. B., First annual rejport on the geology of Vermont, Burlington, 1845, pp. $39-43$.

- - Second annual report on the geology of Vermont, Burlington, 1846, pp. 233-236.

Billings, E., Note on the discovery of fossils in the "Winooski marble" at Swanton, Vt.: Am. Jour. Sci., 3d ser., vol. 10, 1872, pp. 145, 146.

Brainerd, Ezra, The geological features of the marble belt: Papers and Proc. Middlebury Hist. Soc., vol. 1, pt. 2, 1885, pp. 9-21.

Dale, T. Nelson, On the structure of the ridge between the Taconic and Green Mountain ranges in Vermont: Fourteenth Ann. Rept. U. S. Geol. Survey, pt. 2, 1894, pp. 525-549.

- On the structure and age of the Stockbridge limestone in the Vermont Valley: Bull. Geol. Soc. America, vol. 3, 1891, pp. 514-519.

- Structural details in the Green Mountain region and in eastern New York (second paper): Bull. U. S. Geol. Survey No. 195, 1902, pp. 10-13, Pl. I, B.

DaNA, James D., An account of the discoveries in Vermont geology of the Rev. Augustus Wing: Am. Jour. Sci., 3d ser., vol. 13, 1877, pp. 332-347, 405-419.

On the relations of the geology of Vermont to that of Berkshire: Am. Jour. Sci., 3d ser., vol. 14, 1877, pp. 37-48, 132-140, 202-207, 257-264.

DAY, DAvid T., Report on mineral industries in the United States at the Eleventh Census, 1892, pp. 621-630.

Day, Wriliam C., Marble: Twentieth Ann. Rept. U. S. Geol. Survey, pt. 6, continued, 1899, pp. 405, 406, 447, 455.

Marble: Eighteenth Ann. Rept. U. S. Geol. Survey, pt. 5, continued, 1897, pp. 975-992.

Edson, George E., Geology of the town of Swanton: Sixth Rept. State Geologist of Vermont, 1907-8, pp. 217-219.

Foerste, August F., New fossil localities in the early Paleozoics of Pennsylvania, New Jersey, and Vermont: Am. Jour. Sci., 3d ser., vol. 46, 1893, p. 435.

HAGER, AlberT D., The marbles of Vermont, 1858, $16 \mathrm{pp}$.

Hall, Frederick, Catalogue of minerals found in the State of Vermont, Hartford, 1824, pp. 29, 30.

HAYes, A. A., On serpentine rock [Vermont]: Am. Jour. Sci., 2d ser., vol. 21, 1856, pp. 382-385.

The so-called verd-antique marble from Roxbury, Vt.: Proc. Boston Soc. Nat. Hist., vol. 5, 1856, pp. 260-263.

Hitchcock, Charles H., The Winooski marble of Colchester, Vt.: Proc. Am. Assoc. Adv. Sci., vol. 16, 1867, p. 119.

Geological sections across New Hampshire and Vermont: Bull. Am, Mus. Nat. Hist., vol. 1, 1884, p. 155.

Remarks on the stratigraphic structure of the Cambrian and Cambro-Silurian rocks of western Vermont: Proc. Boston Soc. Nat. Hist., vol. 18, 1877, pp. 191-193. [Remarks on the equivalency of the Eolian limestone of Vermont]: Bull. Geol. Soc. America, vol. 1, 1890, p. 513. 
HiTchCock, Edward, assisted by Albert D. Hager, Edward Hitchcock, jr., Charles H. Hitchcock, Report on the geology of Vermont, descriptive, theoretical, economical, and scenographical, 1861, vol. 1, pp. 394-424; vol. 2, pp. 690-692, 751-780.

MaNLEY, J. E., Rutland County marble, with a history of the marble industry of Vermont and a statement of comparative value: First Ann. Rept. Vermont State Board Agr., Man. and Min., 1872, pp. 656-666.

Merrifu, George P., Special reports on mines and quarries: Twelfth Census U. S., 1900, pp. 791-795.

- Stones for building and decoration, 3d ed., 1908, pp. 231-239, 372-374, 513.

Newberry, J. S., Building and ornamental stones: Repts. and Awards, U. S. Centennial Com. Internat. Exhib. 1876, vol. 3, groups 1, 2, 1880, pp. 137-160.

Perkins, George H., The Winooski or Wakefield marble of Vermont: Am. Naturalist, vol. 19, 1885, pp. 128-136. Abstract, Proc. Am. Assoc. Adv. Sci., vol. 31, 1882, p. 388.

Report on the marble, slate, and granite industries of Vermont, 1898, pp. 10-42.

Report of the State geologist on the mineral industries of Vermont for 1899-1900, pp. 31-57.

Leports of the State geologist on the mineral industries and geology of certain areas of Vermont: Third, for 1901-2, pp. 41-44, 88-90; Fourth, for 1903-4, pp. 44-47, 143, Pls. XX-XXIV; Fifth, for 1905-6, pp. 4-7, 53-61; Sixth, for 1907-8, pp. 9-32, 189-209, 221-264, Pls. I-VI, XXXIX; Seventh, for 1909-10, pp. 298, 308-309, 318320, 332-336, 349-351, Pls. LII, LXVII, LXIX-LXXI.

Perry, George W., The relation of the strength of marble to its structure: Eng. and Min. Jour., vol. 52, 1891, p. 453.

Ries, HeInrich, The limestone quarries of eastern New York, western Vermont, Massachusetts, and Connecticut: Seventeenth Ann. Rept. U. S. Geol. Survey, pt. 3, continued, 1896, pp. 806-810.

Seely, Henry M., The marble fields and marble industry of western New England: Papers and Proc. Middlebury Hist. Soc., vol. 1, pt. 2, 1885, pp. 23-52, and appendix, The marble border of western New England.

The geology of Vermont: The Vermonter, vol. 5, no. 7, 1901, pp. 53-67.

Thомpson, ZADOCK, History of Vermont, natural, civil, and statistical, Burlington, 1842, pp. 14-20, 40-58.

Wolff, J. E., On the Lower Cambrian age of the Stockbridge limestone: Bull. Geol. Soc. America, vol. 2, 1891, pp.331-338.

Young, Augustus, Preliminary report on the natural history of Vermont, 1856.

\section{THE MARBLE BELTS OF WESTERN VERMONT.}

\section{PHYSIOGRAPHY.}

Before considering the geologic relations of the marble beds of western Vermont it may be useful to recall the surface features of this part of the State, which are somewhat complex.

Beginning at latitude $44^{\circ} 15^{\prime}$, or about 15 miles south of the latitude of Burlington, near the Addison-Chittenden county line, the west flank of the Green Mountain range lies near longitude $73^{\circ} 5^{\prime}$ and extends thence southward with minor deviations for 36 miles to Coxe Mountain, a little north of Pittsford village, about latitude $43^{\circ}$ $44^{\prime}$ and longitude $73^{\circ} 3^{\prime}$. From this point the range curves eastward, forming an embayment that is 6 miles wide near Rutland, where it reaches longitude $72^{\circ} 56^{\prime}$. This embayment extends 43 miles south 
from Coxe Mountain, gradually curving westward to the ManchesterSunderland line, where the west flank is again at longitude $73^{\circ} 5^{\prime}$. From that line it curves 3 miles farther west in a distance of $8 \frac{1}{2}$ miles and reaches longitude $73^{\circ} 9^{\prime}$ near the Shaftsbury-Glastenbury line. The length of the flank of the range here considered is thus $87 \frac{1}{2}$ miles.

West of the Green Mountain range and 3 miles southwest of Brandon village, at about latitude $43^{\circ} 46^{\prime}$ and near longitude $73^{\circ} 7^{\prime}$, is the north end of the Taconic range, which extends with a course more or less parallel to that of the Green Mountain range to latitude $43^{\circ}$, the south limit of the area under consideration, near the ArlingtonShaftsbury line and beyond. The valley between these two ranges, known as the Vermont Valley, varies greatly in width, being 4 miles wide near Manchester, 2 miles near Brandon, but in places between East Dorset and Danby only one-fourth of a mile. This narrowing is due to the fact that for 6 miles, between the Manchester-Dorset line on the south and latitude $43^{\circ} 20^{\prime}$ on the north, the Taconic range widens out eastward for 5 miles in the Dorset Mountain mass, which rises to an altitude of 3,000 feet above the valley bottoms. Opposite the Rutland embayment there is a minor range between the Taconic and Green Mountain ranges. This intermediate range begins with Pine Hill, in Proctor, 945 feet above the valley (latitude $43^{\circ} 40^{\prime}$ ), and extends 23 miles south to Danby Hill, 1,500 feet above the valley, a little north of Dorset Mountain (latitude $43^{\circ} 20^{\prime}$ ). The width of this range is from $1 \frac{1}{2}$ to $2 \frac{1}{2}$ miles, averaging about 2 miles.

North of the north end of the Taconic Range the surface between the Green Mountain range and Lake Champlain presents only minor irregularities, but between Middlebury and Monkton (latitude $44^{\circ} 3^{\prime}$ and $44^{\circ} 15^{\prime}$ ) and to the west Snake, Buck, and Hogback mountains rise 700 to 900 feet above the valleys.

The longest marble belt lies partly in the Vermont Valley, between the Green Mountain and Taconic ranges, and partly between the Taconic Range and the intermediate range from Pine Hill to Danby Hill. It also extends north of the Taconic Range, ending between Middlebury and Bristol, and its total length from north to south is about 80 miles.

Beginning in the northern parts of Charlotte and Hinesburg and extending north into Shelburne, Burlington, and Colchester, according to the Vermont report of 1861 , is another marble belt, which, however, is not considered in this bulletin. One or two quarries were once opened in it.

Within the Taconic Range itself west of Rutland is still another marble belt, 6 miles long and half a mile wide, occupying a minor longitudinal valley, through which Castleton River flows in the northsouth part of its course. This is the West Rutland belt of marble. 
At several other points within the Taconic Range, north and south of this minor belt, there are small marble areas which will be considered more fully beyond. Most of these geographic features are shown on the map (Pl. I; see also Pl. IX). ${ }^{1}$

\section{AREAL GEOLOGY.}

The geologic map (Pl. I) shows the probable areal distribution of the geologic formations which include or are closely related to the marble areas. Such maps represent the general character of the rock surface as it would probably appear if divested of sand, gravel, clay, soil, marsh, and vegetation.

The rocks of the Green Mountain Range on the east include various gneisses, mostly of igneous origin, mantled on the west side by a belt of quartzite and schist, which prior to metamorphism consisted of sandstone and shales that in turn were originally marine deposits of sand and clay. This formation of quartzite and schist passes under the Vermont Valley and reappears on the intermediate ridge. On the west it is succeeded by a belt of more or less quartzose dolomite, associated in places with quartzitic beds. This extends along the valleys and immediately underlies the belt of calcite marble. To this formation belong the dolomite marbles of Pittsford and East Monkton, described on pages 45-46. Then follows the marble belt proper, consisting of beds of calcite marble alternating with beds of dolomite and in places of graphitic mica schist. The localities whère marble has actually been observed, whether of commercial value or not, are indicated on the map by a special symbol and so are also the marble quarries in operation and most of the idle ones. The direction of the dip of the beds is also shown by symbols.

Overlying the marble on the west side of the Vermont Valley is a great mass of schist, a roughly slaty rock, consisting mainly of fibrous white mica and quartz, together with the soda feldspar (albite), graphite, chlorite, pyrite, etc. It includes here and there small beds of quartzite, originally sandstone, of fine quartz conglomerate, and of more or less crystalline limestone, and is generally veined with quartz and contains many quartz lenses. These schists were originally clays of marine deposition brought into the sea by rivers from the erosion of granitic and other rocks on the east. When the calcareous sediments of the underlying series were metamorphosed into marble these clays passed into mica schists and the small sandy beds into quartzite. These schists constitute the considerable mountains

1 The surface features of nearly all this territory and their relations to the calcareous rocks which include the marbles are shown in the colored relief map, Plate I, of Taconic physiography: Bull. U. S. Geol. Survey No. 272, 1905, also a view of the Vermont Valley in Plate IV of the same bulletin. Plate LXVI of the Fourteenth Ann. Rept. U. S. Geol. Survey, pt. 2, 1894, shows views of the three ranges referred to, and Plate LXX the north face of Dorset Mountain. 


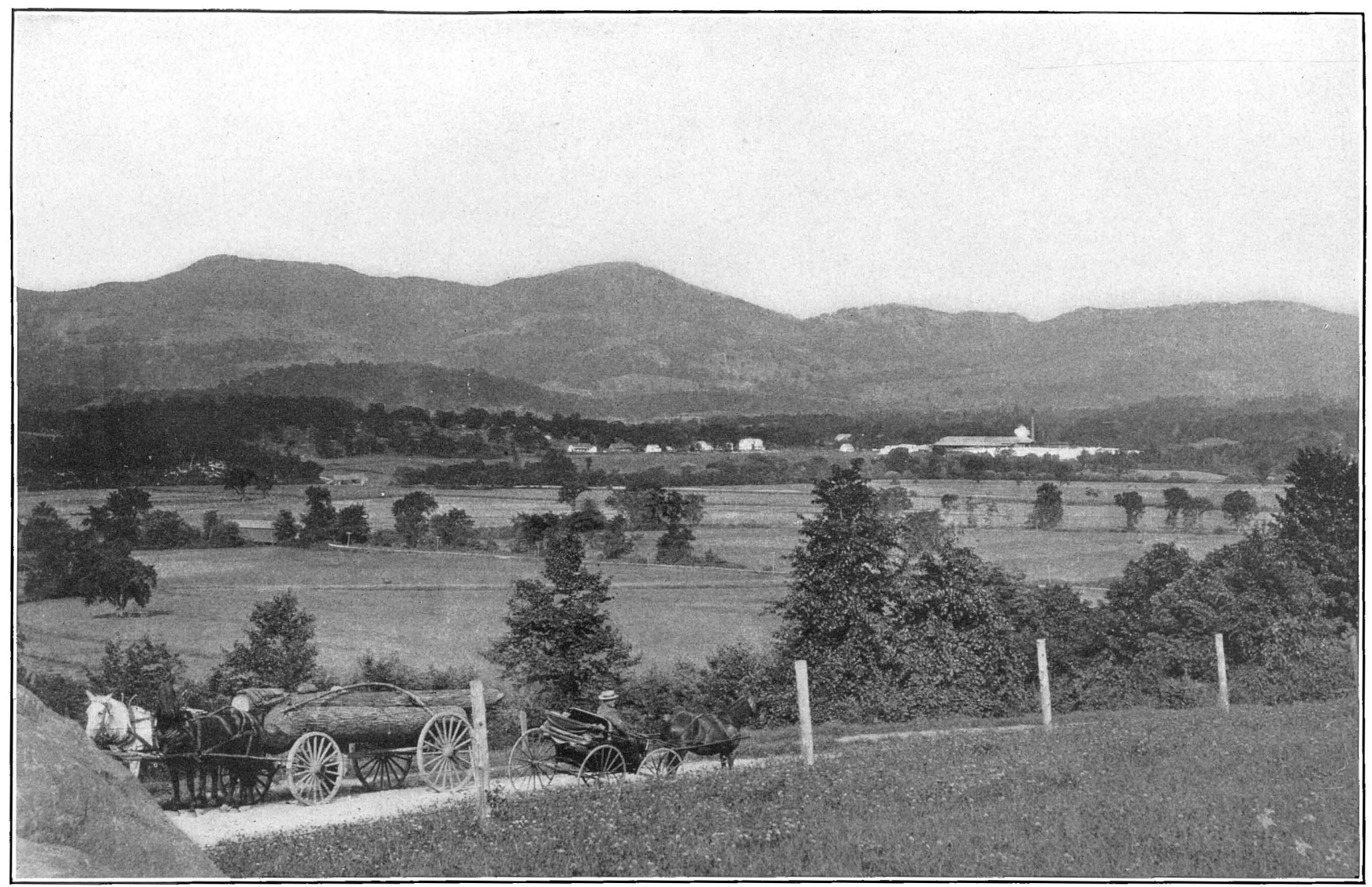

VIEW FROM POINT NEAR PITTSFORD ACROSS THE MARBLE BELT. LOOKING N. $75^{\circ} \mathrm{W}$. ACROSS THE OTTER CREEK VALLEY. Showing the Taconic Range (schist) and the marble mill at Fowler. The marble belt occupies the space between the mill and the range. 

of the Taconic Range-Dorset, Bear, Equinox, Red, and Grass mountains and Green Peak.

It will be observed from the contours of the map that the boundary between the marble and the schist in the towns of Dorset and Manchester runs at a considerable elevation, being in places at the 2,000foot and in others even at the 2,500-foot contour, or from 1,350 to 1,850 feet above the valley bottom. The intricate course of this boundary, as shown on the map, is due to the fact that the schist once completely covered the marble area and has been unequally eroded from it. It will be noticed that the reentrant angles in the boundary line generally follow the courses of the streams. This is because the streams have, as it were, eaten their way in the long lapse of time through the schist capping down into the underlying marble. This is a marked feature of the boundary about Dorset, Equinox, and Red mountains. The triangular schist capping of Green Peak in Dorset is a remnant of the schist mass which once connected Dorset and Equinox mountains and filled the Vermont Valley. In the same way the West Rutland belt of marble has become exposed by the erosion of the schist mass which once overlaid it, and so has the small marble area 4 miles north-northwest of it. Between Proctor village and the West Rutland belt of marble are several small marble outcrops which indicate either the presence of small calcareous beds within the schist or else the thinness of the schist mass along a northnorthwest line about half a mile east of Castleton River. But the little marble area in Ira seems to be an exposure of the marble series itself.

Attention should be called to a simple but important feature of the marble belts-that the upper part of the marble will always be found, except where faulting has occurred, next to the schist and the lower part next to the underlying dolomite. At the present time the most productive quarries are near the schist.

Finally, where two formations which do not follow one another in the natural order of superposition are brought together at the surface, as shown by a geologic map, a fault or fracture along which one or the other has ridden up or down must have occurred to cause the anomalous juxtaposition. Such faults abound on the intermediate range. There is one at its south end between Danby Hill and Dorset Mountain. Another begins on Clark Mountain and extends to Pine Hill; Proctor, and beyond, bringing the quartzite that underlies the dolomite to the level of the schist that overlies the marble. But these faults have no immediate bearing on the economic geology of the marble belt. $\quad$ Two others, however, not shown on the map because

1 Thesefaults are described in detail in the writer's paper On the structure of the ridge between the Taconic and Green Mountain ranges in Vermont: Fourteenth Ann. Rept. U. S. Geol. Survey, pt. 2, 1894, pp. 525-549. 
of their uncertain course, do affect the marble belt and will be referred to under "Structural relations" (pp. 90, 93).

\section{THE STRATIGRAPHIC SUCCESSION.}

Next in importance to determining the boundaries of the marble areas and of the contiguous formations is to ascertain the probable thickness of these formations and to refer them to their respective geologic systems.

The older gneisses of the Green Mountain range have little to do with the marble, and the overlying quartzites and schists not much more. A measurement of the latter on Bald Mountain near Bennington amounts to 1,600 feet, and it is all of Lower Cambrian age. The thickness of the overlying dolomite is still uncertain. It can not be less than 500 feet and may in places be much more. The discovery of Lower Cambrian fossils by Wolff and Foerste in 1890 on the east side of the intermediate range, about $1 \frac{1}{2}$ miles north of Rutland, near East Creek, opposite the Baxter farm, in dolomite 500 feet east of the quartzite, fixed the age of the lower 300 feet of the dolomite. ${ }^{1}$

Measurements made in 1891 by the writer near Chippenhook, in Clarendon, along the axis and on the west side of the intermediate range, showed that the dolomite and marble together measure there about 1,200 feet, of which at least the lower 470 feet is mostly dolomite and of Lower Cambrian age. ${ }^{2}$

A measurement made by the writer in 1903 across the syncline of the dolomite cut by Sucker Brook east of Lake Dunmore gives it an approximate maximum thickness of 765 feet.

One estimate of the thickness of the dolomite and marble is 1,200 feet; from this deducting 500 feet for the dolomite would leave 700 feet for the marble. Another estimate made near North Adams, Mass., between the north end of Mount Greylock and the base of the Green Mountain range-that is, between the schists over the marble and the quartzite below the dolomite and marble-yielded 1,400 feet for both; allowing 500 feet for the dolomite would leave 900 feet for the marble. ${ }^{3}$ Another estimate, made between the top of the Cambrian quartzite at the north foot of Danby Hill and the base of the schist on the northeast shoulder of Dorset Mountain, gives 1,400 feet for the entire thickness of both, divided about equally between the dolomite and the marble. Hitchcock and Hager ${ }^{4}$ estimated the

1 See Wolff, J. E., On the Lower Cambrian age of the Stockbridge limestone: Bull. Geol. Soc. America, vol. 2, 1891, pp. 331-338.

2 Dale, T. N., On the structure and age of the Stockbridge limestone in the Vermont Valley: Bull. Geol. Soc. America, vol. 3, 1892, p. 514; Fourteenth Ann. Rept. U. S. Geol. Survey, pt. 2, 1894, pp. 540, 541, 549, Sections A, T, Pls. LXVII, LXVIII.

${ }^{3}$ See Mon. U. S. Geol. Survey, vol. 23, 1894, p. 190.

4 Hitchcock, Edward, and Hager, A. D., Geology of Vermont, vol. 1, 1861, pp. 417, 418, fig. 264. 
thickness of both on Green Peak (Mount Eolus) as 1,970 feet, of which they assigned 707 feet to the marble and 1,263 feet to the dolomite ("limestone"); but as the actual vertical distance between the valley floor at East Dorset (788 feet) and the base of the schist cap (2,500 feet; see contours on geologic map, Pl. I) is 1,712 feet, only 1,005 feet should be assigned to the dolomite, and that figure should be further reduced to allow for the folding in the Vermont Valley.

An estimate by F. H. Moffit, based on the map and his barometric observations at the same locality, makes the thickness of the marble from the dolomite below the Folsom \& Kent (now Blue Ledge) quarry to the base of the schist about 500 feet.

The marble has been shown by the investigations of Wing and others to include beds of Chazy age and probably some of Trenton age above them and possibly some of Beekmantown age below them. There is, however, a question as to whether any or how much of the dolomite is of Beekmantown age. As this formation along Lake Champlain is largely dolomite, it would naturally be sought among the dolomite beds of the Vermont Valley. Seely ${ }^{1}$ is inclined to correlate some if not the whole of the dolomite with the Beekmantown.

The thickness of the marble as obtained from the records of drill cores and from sections at the quarries (pp. 86, 88, 93, 95) ranges from 335 to 851 feet, measured from the base of the schist downward. A fair average of all the estimates is 663 feet.

The question as to the presence of the Middle and Upper Cambrian in the dolomite can not be discussed here. Thus far no fossils typical of these time divisions have been found in either the dolomite or the marble of the Vermont Valley. From what is known of the Ordovician formations about the Adirondack Mountains and on Lake Champlain it seems probable that the total thickness of the dolomite and marble, after deducting the Lower Cambrian part of the dolomite, is inadequate to fully represent Beekmantown and Chazy time, and that for this reason the two must include some intervals of extremely slow deposition or of nondeposition.

The schist which overlies the marble has been found to range between 2,000 and 2,500 feet in thickness at several points in the Taconic Range in Massachusetts and Vermont. It is in many places much thinner than this, owing to erosion. Its age is regarded as Middle (Trenton) and Upper Ordovician.

The following table is based on the foregoing more or less incomplete data. For each of the formations is given a condensed summary of its rock characteristics. The symbols in the first column correspond to those used on the geologic map (PI. I).

\footnotetext{
1 Seely, H. M., Preliminary report on the geology of Addison County: Seventh Rept. State Geologist, 1910, p. 257, PI. XLVIII.
}

$49311^{\circ}-\mathrm{Bul1} .521-12-5$ 
Stratigraphic table of the marble areas and adjacent.formations.

\begin{tabular}{|c|c|c|c|c|}
\hline $\begin{array}{c}\text { Map } \\
\text { sym- } \\
\text { bol. }\end{array}$ & Formation. & Rock characteristics. & Geologic age. & $\begin{array}{c}\text { Approxi- } \\
\text { mate } \\
\text { thickness. }\end{array}$ \\
\hline $\mathrm{Ob}$ & $\begin{array}{l}\text { B erkshire } \\
\text { schist. }\end{array}$ & 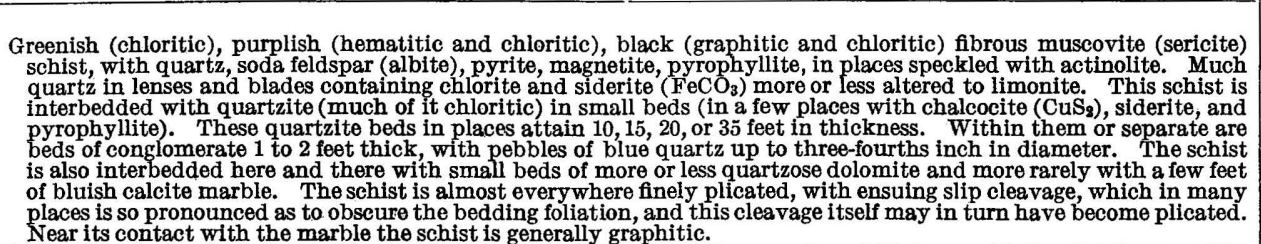 & $\begin{array}{l}\text { Ordovician, probably } \\
\text { Upper and Middle } \\
\text { (Trenton) Ordovi- } \\
\text { cian. }\end{array}$ & $\frac{\text { Feet. }}{2,000-2,500}$ \\
\hline Om & Marble. & $\begin{array}{l}\text { Alternating beds of calcite marble of various grades of texture, white, gray (graphitic), greenish banded (muscovitic, } \\
\text { actinolitic), interbedded with bluish or grayish untwinned dolomite, and with muscovite schist in small beds, in } \\
\text { places graphitic and up to } 40 \text { feet thick. Some the marble beds are very quartzose and muscovitic. The uppermost } \\
\text { part of the marble is generally more or less graphitic, and therefore of various shades of bluish gray. "(See for details }\end{array}$ & $\begin{array}{c}\text { Trenton, Chazy, and } \\
\text { Beekmantown(?) }\end{array}$ & $500-900$ \\
\hline$€ d$ & Dolomite... & 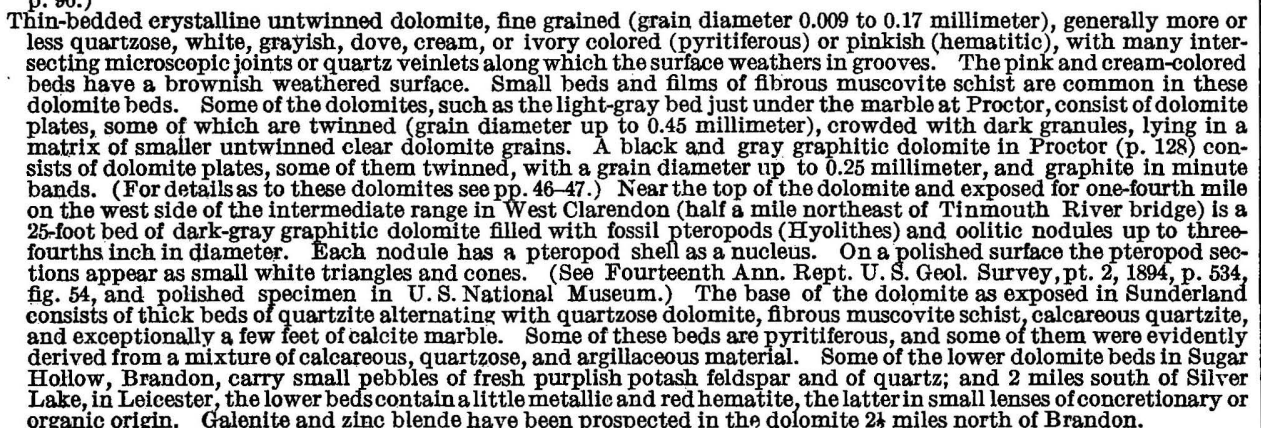 & $\begin{array}{l}\text { Beekmantown(?) and } \\
\text { Lower Cambrian. }\end{array}$ & $500-800$ \\
\hline$\epsilon_{q}$ & $\begin{array}{l}\text { Quartzite and } \\
\text { schist. }\end{array}$ & 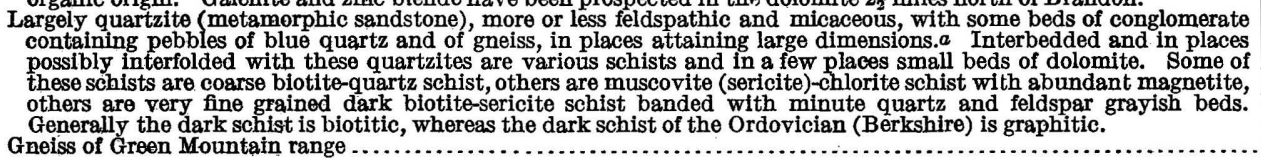 & $\begin{array}{l}\text { Lower Cambrian. . } \\
\text { Pre-Cambrian..... }\end{array}$ & 1,600 \\
\hline
\end{tabular}

$a$ See Dale, T. N., The Cambrian conglomerate of Ripton, in Vermont: Am. Jour. Sci., 4th ser., vol. 30, 1910, pp. 267-270, figs. $2,3$. 


\section{STRUCTURE OF THE MARBLE BELTS.}

ORIGIN.

All the materials which now constitute these different series of rocks must, from their parallelism, as far as observations to the present extend, be supposed to have been originally laid down in the sea in horizontal position. Their present generally inclined attitude and incomplete extension are explained by two important events.

1. In consequence of a powerful crustal contraction at the close of Ordovician time, operating mostly in a west-northwest to east-southeast direction, the sediments not only became crystalline, but were intensely folded and in places faulted. It will be noticed from the geologic map (Pl. I) that in the southern part of the marble belt (Arlington, Sunderland, and Manchester) the Vermont Valley and the axes of the folds (strike) have a general north-northeast trend; that in Dorset, Danby, Tinmouth, and Clarendon their trend is more nearly north; that from a point a little north of the Clarendon-West Rutland line the trend changes to north-northwest, and so continues to the north end of the Taconic Range, in Brandon; and that from there on it is again nearly north.

2. During the lapse of ages the crests of these folds have become eroded by atmospheric acids and stream action, so that the schist mass has been removed from the tops of the marble folds and in one place even from the trough of the fold. This erosion has also in places penetrated the underlying marble and thus exposed the dolomite.

GENERAL SECTIONS.

The three general sections on Plate II show the approximate original outlines of these folds and the portions left by erosion. The location of these sections is shown by numbered lines on the geologic map (Pl. I).

Section I runs from a point a mile north of Center Rutland westnorthwestward to the top of the Taconic Range, near the Castleton town line. Beginning on the east, it crosses the fault on the intermediate range which begins on Clark Mountain, in Tinmouth, and extends nearly to or possibly beyond the Pittsford-Chittenden line. By this fault the schist and quartzite of the Lower Cambrian have been thrust over the Ordovician (Berkshire) schist, which forms the west side of Pine Hill and which there overlies a narrow belt of marble. This hill is a syncline (trough). The section crosses Otter Creek Valley, which here corresponds to a complex anticline (arch), the dolomite appearing in the center with the marble on both sides. The schist ridge between the West Rutland (Castleton River) Valley and Center Rutland-Proctor (Otter Creek) Valley is a complex syncline. The section next crosses the West Rutland Valley at the Albertson 
quarry. This valley is an anticline of marble from which the schist has been eroded. The same anticline reappears in the small marble area east of Biddie Knob and $1 \frac{1}{2}$ miles west of Fowler. On the west side of the West Rutland Valley the marble dips west under - the Berkshire schist, which forms the synclinorium of the Taconic Range. The dolomite is probably not far below the marble floor of the West Rutland Valley.

Section II, made by F. H. Moffit, begins at the east foot of Clark Mountain, in Tinmouth, runs nearly west-northwest, passing about half a mile north of Tinmouth Pond, and extends to the Wells township line. The east side of Clark Mountain is a trough of Berkshire schist underlain by the marble. The fault passes near the top of the mountain, where the Lower Cambrian quartzite and schist have been thrust up, so as to be in contact with the Berkshire schist. West of this the folds are again normal. The quartzite near Tinmouth Pond dips west under the dolomite of the central part of the valley. There must be an anticline on its west side. The marble beds above the dolomite dip west under the schist mass of Tinmouth Mountain and The Purchase. That the structure of these masses is complex is shown by the reappearance of the marble $1 \frac{1}{2}$ miles south of the top of Tinmouth Mountain and along its strike between Harrington Hill and Dutch Hill, in Danby and also by the small area of dolomite, probably belonging in the marble, at the west foot of The Purchase.

Section III begins on the Green Mountain range near the head of Downer Glen (Bourn Brook), on the Manchester-Winhall township line, and runs about west-northwest through Manchester village ("Street") and the top of Equinox Mountain, ending at the SandgateManchester town line. At the east end of the section crop out the pre-Cambrian gneisses of the Green Mountain range, whose unconformable relations to the overlying Lower Cambrian are finely exposed in the bottom of Downer Glen. ${ }^{1}$ This locality affords evidence of a crustal movement and erosion in the region prior to Cambrian time. In section III the foliation of the pre-Cambrian gneiss is therefore represented as not parallel to the bedding of the overlying Cambrian and also as eroded before the deposition of the latter. These gneisses formed the ocean floor upon which the Cambrian quartzite and schist and the overlying dolomite and marble were deposited. The section next crosses the entire quartzite and schist formation which flanks the range. In the lower part of Lye Brook this formation lies in a syncline in which the lower beds of the dolomite have been preserved from erosion. On this brook near the Manchester-Sunderland town line, about $2 \frac{1}{2}$ miles south of the line of section III, a loose rectangular block of coarse micaceous quartzite,

1 Dale, T. N., Structural details in the Green Mountain region and in eastern New York (second paper): Bull. U.S. Geol. Survey No. 195, 1902, p. 18, fig. 7. By error the strike symbol of the gneiss and its foliation are drawn in this figure N. $68^{\circ} \mathrm{E}$. instead of N. $68^{\circ} \mathrm{W}$., as marked. 
probably from a near-by ledge, was found in 1899 full of impressions of the spines of the trilobite Olenellus, typical of the Lower Cambrian. Between the lower part of Lye Brook and Batten Kill the quartzite forms an anticline. The Vermont Valley from the Batten Kill to a point about three-fourths of a mile west of the Equinox House is occupied by the dolomite and consists of a broad syncline made up of minor folds. The steep east slope of Equinox Mountain up to elevations of 2,300 to 2,400 feet consists of the marble, but with dips indicating at least two minor folds (two anticlines and two synclines).

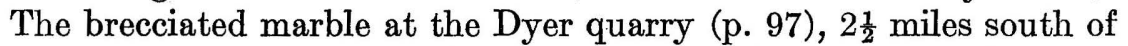
the line of section III, points to a possible fault running between Manchester Street and the beginning of the steep slope of the mountain. Equinox Mountain itself appears to be a flat-topped anticline and thus exceptional among the mountains of the Taconic Range, which are, as a rule, more or less complex synclines.

These sections taken together with the geologic map (Pl. I), will answer as a key to the general geology of the marble belts.

\section{DETAILED SECTIONS.}

The general sections are supplemented by nine detailed sections (Pl. III), drawn on the scale of the enlarged map of the West Rutland belt of marble (Pl. IV), as follows:

$A$, across the east foot of Dorset Mountain north of the Dorset-Danby line.

B, C, D, across the east side of the West Rutland belt of marble.'

$\mathrm{E}, \mathrm{F}$, across the west side of the same belt.

$G$, through the village of Proctor.

$\mathrm{H}$, a little south of $\mathrm{G}$.

I, through the Pittsford quarries.

These sections must be regarded merely as approximations and are designed to afford such assistance by way of suggestion as approximations can give. By means of large-scale mapping and careful instrumental work sections of much greater mathematical value could be constructed.

\section{STRUCTURAL NOTES.}

The following notes are designed to call special attention to a few points in the map and the sections and also to some structural features which could not be represented or explained in either.

Equinox and Bear mountains.-The contours show that the marble makes up the lower 1,000 to 1,300 feet of these mountains. They are masses of marble and dolomite capped by 1,300 to 1,500 feet of schist.

South Dorset.-The symbols on the map show the unusual change in strike on both sides of the valley near South Dorset and extending to Owls Head, a change from about north to northeast-that is, of $40^{\circ}$ to $45^{\circ}$. 
Dorset Mountain.-In this mountain the schist cap extends from the 2,000-foot level (exceptionally on the east side of Dorset Hollow 1,600 feet) to the summits, 3,436 and 3,804 feet, and the marble generally from the 1,600 -foot to the 2,000 -foot level. The mountain is deeply furrowed by erosion and the marble is exposed on its three sides. As shown in section A, the basal dolomite lies in sharp minor folds up to the second bench on the east side. A little above that the marble begins in almost horizontal attitude and extends to the third bench, on the west side of which it is overlain by schist which from that point constitutes the steeper upper 1,600 feet of the mountain. The newly opened quarries are on this third bench. There is a marked southerly pitch in this part of the mass.

West Rutland anticline (Pl. IV).--In exploring the schist mass on the west side of the valley, about half a mile west of the West Rutland station, the schist foliation (slip cleavage) clearly dips $30^{\circ} \mathrm{E}$., striking in some places N. $10^{\circ}-20^{\circ}$ E., in others N. $25^{\circ}$ W. The bedding, shown by plicated quartz veins, strikes clearly N. $25^{\circ} \mathrm{W}$. and dips across the cleavage at steep angles east or west. The underlying marble, therefore, dips either steeply west at the contact or, by overturn, steeply east.

On the north side of the Castleton River east-west cut in the western schist range, about a mile west-northwest of the West Rutland station, the slip cleavage strikes N. $5^{\circ}-10^{\circ} \mathrm{W}$. and dips $10^{\circ}-20^{\circ}$ E., but the bedding strikes N. $30^{\circ} \mathrm{W}$. and dips steeply to the west in minor folds, parts of which dip east. On the north side of a disused road which sets off from the highway. on the west side of the West Rutland Valley several outcrops show the structure finely.

A little north of the line of section $\mathrm{F}$, about 300 feet east of the road going north, a mass of schist several hundred feet long rises 10 feet above the meadow. It shows slip cleavage dipping $20^{\circ} \mathrm{E}$., crossed by plicated bedding dipping steeply west. This is the most easterly outcrop of schist in this part of the west side of the anticline, and its contact with the marble can not be far from it on the east.

In the western schist range at a point about 200 feet above the north-south highway and N. $47^{\circ}$ W. of the red schoolhouse above the West Rutland quarries there is a cliff of schist 40 feet high. The bedding, shown by calcareous beds 3 inches thick, dips alternately east and west in minor undulations, with a general horizontal course crossed by low eastward-dipping slip cleavage. The exposure is 60 feet long.

All these data and the observations in the conspicuous schist ledges near the highway, referred to on page 81, have been incorporated in the western part of section $\mathrm{F}$ and show conclusively the general westerly dip of the bedding in the schist mass and the probable 
anticlinal structure of the valley. The marble of at least this part of the anticline probably also dips west.

In the southern part of the anticlinal valley the schist a little south of the Eastman quarry appears to dip $20^{\circ}-35^{\circ}$ E., as it does at the quarry, but on the west side of the first schist knoll half a mile west of that quarry the bedding dips clearly $50^{\circ} \mathrm{W}$. and is crossed by slip cleavage dipping $15^{\circ} \mathrm{E}$.

That the West Rutland anticline is probably made up of minor folds is indicated by the small synclinal schist tongues which overlie the marble at the north end and near the True Blue quarry, as shown on the map (Pl. I).

Schist ridge west of Proctor and Fowler.-The complex structure of this ridge is indicated by the lenses of marble or dolomite, probably the tops of minor anticlines, shown on the map about midway between the West Rutland and Proctor belts of marble.

The problem as to the dip of the bedding in the schist range west of the West Rutland anticline, and thus as to the dip of the underlying marble, recurs on the east side of the schist ridge west of Proctor and Fowler. Where the quarry railroad cuts the schist nearly west of the north end of the pond the cleavage strikes N. $5^{\circ}-10^{\circ} \mathrm{E}$. and dips $60^{\circ}-65^{\circ} \mathrm{E}$., but the bedding, shown by plicated quartz veins and lenses, dips at a low angle to the west. At a point S. $85^{\circ} \mathrm{E}$. of the tower on the Proctor School the schist has a cleavage strike of N. $10^{\circ} \mathrm{E}$. and dips $55^{\circ} \mathrm{E}$, but with a magnifying glass traces of westward-dipping plicated bedding can be made out in places and are corroborated by plicated quartz veins a little beyond. Again at a point half a mile north-northwest of this last point the cleavage dips $65^{\circ} \mathrm{E}$. and the bedding dips at a low angle to the west or is horizontal.

At a point $1 \frac{3}{4}$ miles south of Fowler marble and schist occur in contact. Some large glacial bowlders rest on the marble near by. ${ }^{1}$ The marble strikes $\mathrm{N} .15^{\circ} \mathrm{W}$. and dips in coarse plications at steep angles to the west or stands vertical, and the schist in immediate contact is in like position, but its plicated bedding is crossed by an eastward-dipping slip cleavage. The boundary here turns to a northwest course, and at a point one-fourth mile northwest the two rocks are within a foot of each other, but both strike N. $21^{\circ} \mathrm{W}$. and dip $40^{\circ} \mathrm{E}$., owing probably to a minor fold in the schist mass.

Opposite the road corner nearly $2 \frac{1}{2}$ miles south of Proctor the schist shows cleavage dipping $40^{\circ} \mathrm{E}$., but plicated bedding dipping west. This structure is shown in the general section I (PI. II) which passes half a mile south of this point.

Structure north and south of Center Rutland.-The narrowing of the Proctor-Pittsford belt southwest of Center Rutland, as shown on the

1 Dale, T. N., Taconic physiography: Bull. U. S. Geol. Survey No. 272, 1905, Pl. VIII, A. 
map, is not more than would result from the presence of the top of a close-folded anticline at that point. The disappearance of the basal dolomite below the marble a few miles south and 300 feet above that point is presumably the result of a northerly pitch of the folds, and the corresponding disappearance of the dolomite north of Center Rutland, (although there are no marble outcrops to fix the exact termination of the dolomite) would be due to a corresponding southerly pitch. These inferential north and south pitches would be just the opposite of those implied in the disappearance of the West Rutland anticline both at the south and the north under the overlying schist.

\section{TRAP DIKES IN THE MARBLE BELTS.}

After the folding of the marble and the overlying schist, a shearing or stretching took place which opened narrow fissures here and there, generally more or less transverse to the folds and deep enough to reach the zone of rock fusion. Along these fissures both marble and schist became injected with lava-like but dense molten material which crystallized as it cooled and solidified. Out of sixteen dikes which were measured one was 25 feet wide, eleven 4 to 10 feet, three 1 to nearly 4 feet, and one 2 to 4 inches. Out of twenty whose courses were taken three ran N. $80^{\circ}$ to $90^{\circ}$ W., eight N. $25^{\circ}$ to $40^{\circ} \mathrm{E}$., and nine $\mathrm{N} .60^{\circ}$ to $70^{\circ} \mathrm{E}$. Out of eleven which were examined microscopically ten proved to be augite camptonite (plagioclase feldspar, hornblende, augite, magnetite, olivine) and one a camptonite (same as above, with little or no augite). A thin section of the 3-foot augite camptonite dike, which crosses the dolomite half a mile north of Proctor and is exposed in the railroad cut, shows slender crystals of labradorite feldspar, larger augite crystals, fine needlelike prisms of brown hornblende, magnetite, apatite, and calcite.

J. F. Kemp made an analysis of a 3-foot camptonite dike cutting a marble quarry about 2 miles south of Proctor. He found on microscopic examination that it consisted of hornblende, augite, plagioclase, and magnetite. ${ }^{1}$

Analysis of camptonite from quarry south of Proctor.

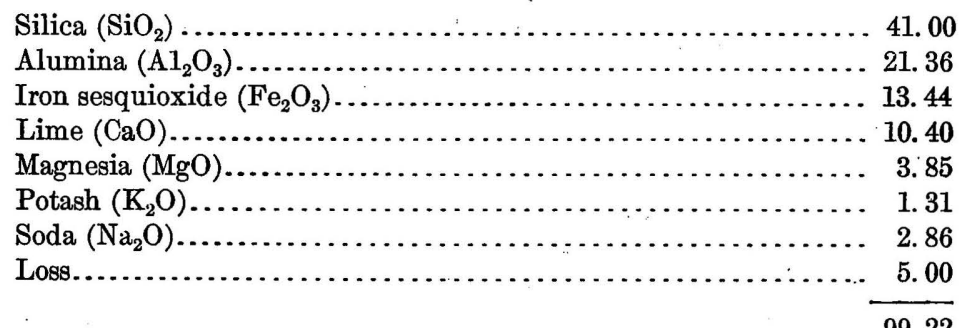

99.22

1 Kemp, J. F., and Marsters, V. F., Camptonite dikes near Whitehall, Washington County, N. Y.: Am. Geologist, vol. 4, 1889, p. 101. Analysis repeated in Bull. U. S. Geol. Survey No. 107, 1893, p. 31. See also Am. Jour. Sci., 3d ser., vol. 36, 1889, p. 250. 


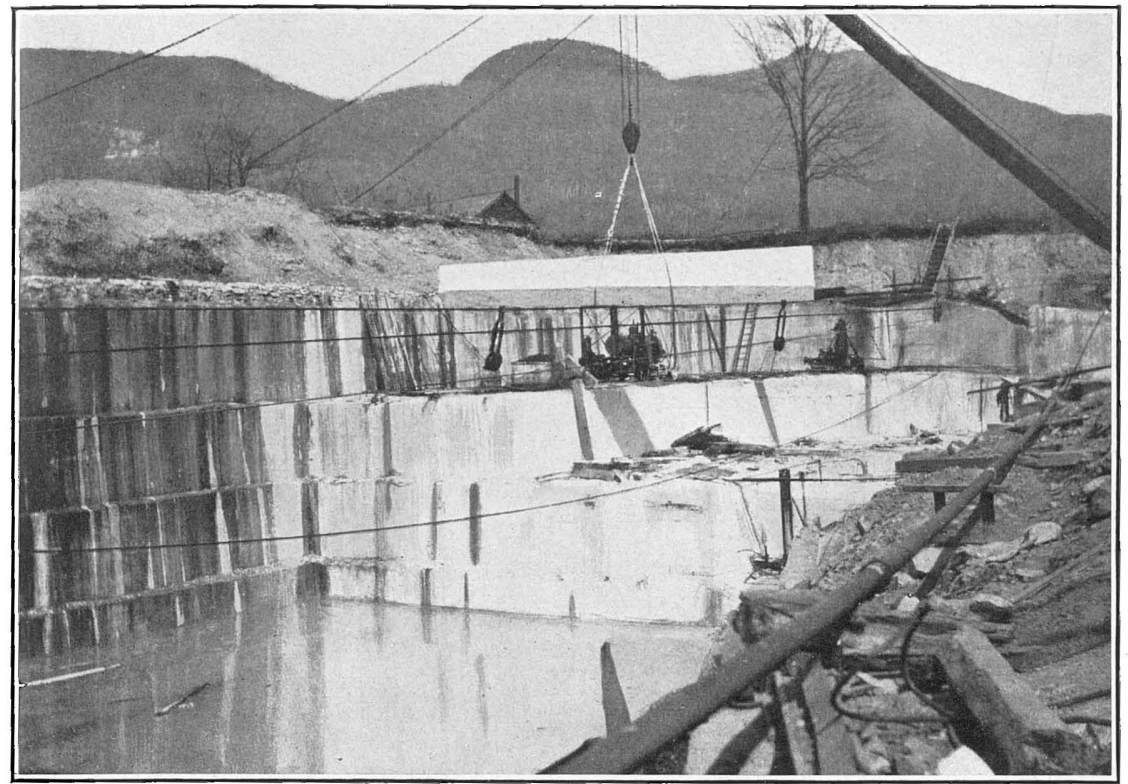

A. PART OF THE PLATEAU QuaRry at SOUTH DORSET.

Showing stripping and in the distance the Owls Head and Green Peak. The block being hoisted is for a 32-foot column for the Art Building at Montreal. The black stains on the quarry walls are caused by the smoke of the cutting machines.

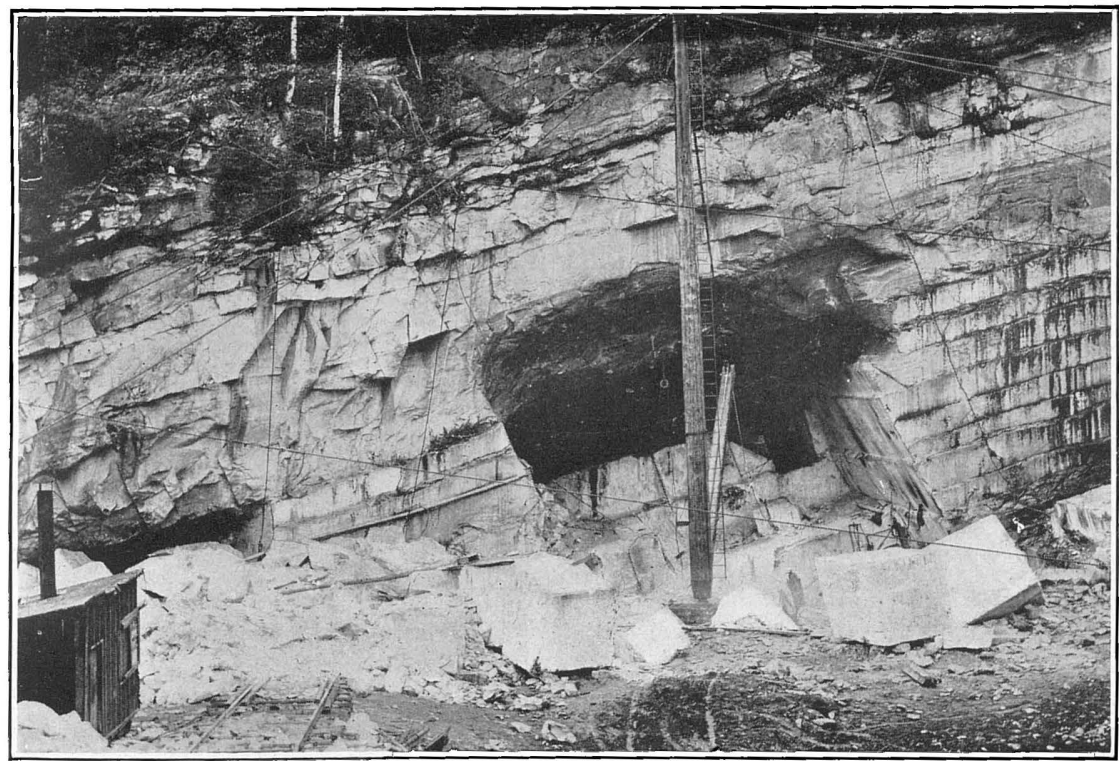

B. TUNNEL OF NEW YORK QUARRY, DORSET MOUNTAIN, DANBY, FROM THE NORTHEAST.

Showing two sets of joints at the left of the tunnel due to a trap dike at the south (not shown in the picture). The marble at the tunnel and north of it is free from joints. 

A dike described by Hitchcock and Hager ${ }^{1}$ as 4 feet thick and 30 feet long, and crossing one of the old marble quarries on Green Peak ("Mount Eolus") was examined by Kemp and found to be an olivine camptonite consisting of olivine, augite, brown hornblende, plagióclase, and a little glassy base. ${ }^{2}$

Near the quarry operated by the Vermont Marble Co. north of the Eastman quarry (see map, Pl. IV), south of West Rutland, a dike with a N. $60^{\circ}-70^{\circ} \mathrm{E}$. course cuts the marble beds. It is about 185 feet long, is 10 feet wide at one end and 4 feet at the other, and reappears at a point about 114 feet east-northeast. It sends out branches 75 feet long southward into the graphitic crinoidal marble beds. In thin section the dike rock has a fine matrix of plagioclase and brown hornblende with porphyritic crystals of micasized plagioclase, of hornblende, and a few of augite, more or less altered to chlorite or to chlorite, hornblende, magnetite, and calcite. It contains also a little magnetite and, apatite and some biotite. This rock is an augite camptonite.

On the schist ridge between Proctor and the West Rutland anticline about one-third mile northeast from the now disused Columbian Quarrying Co.'s quarry and $1 \frac{1}{4}$ miles west-southwest of the Proctor station there is an 8-foot dike with a N. $60^{\circ} \mathrm{E}$. course, which cuts and terminates on the north a small area of bluish limestone or marble surrounded by schist. In thin section this dike is found to consist of plagioclase, chloritized.augite, much magnetite, apatite, and calcite amygdules, and is thus a diabase. This dike probably reappears in Proctor.

The geologic age of these dikes has not been fully determined. They have not suffered metamorphism and are therefore later than the crustal movement which closed Ordovician time, but they can not well be later than the Triassic.

Some of these dikes have a finer-textured, almost glassy rim, due to the more rapid cooling of the part in contact with the rock, and this rim weathers whitish. These dikes have considerable negative economic significance in this region, as the marble for several feet on one or both sides of the dike is usually close jointed parallel to the dike. Plate $\mathrm{X}, B$, a view of the tunnel to the New York quarry on Dorset Mountain, shows the marble full of joints over a space of 80 feet from the upper side of an augite camptonite dike, but the marble is sound on the under side of it. It is not clear whether these joints were formed by the strain that opened the fissure occupied by the dike or whether they were due to the heat of the dike rock.

1 Hitchcock, Edward, and Hager, A. D., Geology of Vermont, vol. 2, 1861, p. 587.

${ }^{2}$ Kemp, J. F., and Marsters, V. F., The trap dikes of the Lake Champlain region: Bull. U. S. Geol. Survey No. 107, 1893, p. 39, fig. 31. 
Hager ${ }^{1}$ gave a sketch of two dikes in limestone (dolomite?) on Danby Mountain which shows such joints parallel to a dike crossing the bedding. Many of the dikes extend for hundreds or thousands of feet horizontally and some of them send off minor ramifications where the rock was shattered.

\section{GEOLOGIC HISTORY OF THE MARBLE BELTS.}

The origin of marble and dolomite has been treated (pp. 21, 33); the areal geology of the region has been explained (p. 62 and Pl. I) and its structure shown in the sections (Pls. II, III, and p. 67); and the stratigraphic succession has been given (p.66). In order to bind all these facts together and complete the geologic treatment of the marble belts it remains to outline very briefly from all these data the probable geologic history of the marble region.

1. After a very long period of atmospheric erosion the gneiss mass which is now exposed on the Green Mountain Range and which must also be supposed to continue westward under the Vermont Valley and the Taconic Range became gradually submerged, at least in its western part. The ocean which then occupied the central portion of the continent advanced eastward. The action of its waves and the erosion by the streams which emptied into it supplied beach and stream pebbles and sand from the gneisses of the land. At times and in places the product of erosion was clay or a mixture of clay and sand. These pebbles, sands, and clays were spread over the ocean floor throughout the region of the marble belts, the coarser material remaining near shore. From the great thickness of the Cambrian rocks which these sediments now form this kind of sedimentation must have continued for a very long period.

2. Next came the calcareous sedimentation represented by the dolomite of the table (p. 66). In view of the uncertainty which still hangs over the origin of dolomite we may suppose either the deposition, largely by the agency of marine organisms, of several hundred feet of calcitic sediments which subsequently suffered dolomitization under water or else the existence of conditions favorable to the chemical precipitation of magnesium and calcium carbonate or dolomite. In either case the sedimentation during this period included a little mechanical sedimentation of clay and quartz and feldspar sand. The graphitic dolomite beds point to a carbonaceous sediment of organic origin, possibly from marine algæ. The pteropods of the graphitic dolomite of West Clarendon (p. 66) are gastropods adapted for swimming. At the present day pteropods frequent the ocean surface.

During periods 1 and 2 we must suppose a slow subsidence of the sea bottom to make room for sediments of such great thickness.

1 Hager, A. D., Geology of Vermont, 1861, vol. 2, p. 586, fig. 318. 
Whether this subsidence was intermittent or alternated with slight reelevations can not yet be determined.

3. Conditions of sedimentation suffered a marked change at the time corresponding to the beginning of the formation of the marble deposit, so that the sediments became very largely calcitic and but exceptionally dolomitic, or, if the theory of dolomitization is accepted, there came a time when dolomitization occurred only at intervals, most of the beds retaining their calcitic composition. The calcitic sediments out of which the calcite marble beds were later formed were largely of organic origin. Crinoids, corals (not reef builders), gastropods, cephalopods, and brachiopods were the principal animals concerned in the physiologic process of extracting lime from sea water and contributing their calcareous parts to the calcitic sediment. There may have been at the same time also some chemical precipitation of calcium carbonate. In order to account for the dolomite interbedded with the calcite marble we must suppose intervals of the submarine dolomitization of calcitic beds largely of organic origin or else intervals during which the conditions were favorable to the chemical precipitation of dolomite, and organic sedimentation largely ceased.

Even during this period of mainly organic calcareous sedimentation the streams continued to bring into the sea, again and again, a little clay and sand which were distributed over the ocean floor and became interstratified with the fragments of crinoids, corals, etc., and the calcitic ooze originating from their disintegration and partial solution. During the later part of the calcitic deposition the sediments in many places became darkened by carbonaceous matter, probably derived from decaying marine algæ, etc.

4. Owing to some far-reaching geographic change on the land mass, probably an elevation of the land that increased the erosive power of streams, the sea, which during the entire period of calcareous sedimentation (corresponding to both the dolomite and the marble) had received but little clay or sand from the land, began now to receive large amounts of these materials, particularly of clay. This was distributed throughout the area of calcareous sedimentation and, to judge from the great thickness of the schists into which this material was later metamorphosed, this kind of sedimentation must have continued for a long time. A gradual subsidence of the ocean floor along the coast line must also have kept pace with the accumulating sediments.

5. At the close of Ordovician time a powerful but slow crustal movement took place, affecting the whole eastern part of the United States. It consisted in a contraction across a laterally undulating axis with a general northeast to north-northeast trend. The effect of this movement upon this region was fourfold. (a) It metamor- 
phosed all the sediments overlying the pre-Cambrian gneisses; the sands and sandstones became quartzite, the clays and shales became mica schist, and the calcareous beds became crystalline dolomite and calcite marble. (b) It folded the entire series and these folds became more or less compressed and inclined, mostly to the east; and, owing possibly to a minor contraction operating at right angles to the main one, the axes of the folds were made to undulate in a vertical direction, thus producing pitching folds. (c) One of the first effects of this folding was the emergence of the rock surface above the sea and the westward retreat of the shore line. (d) One of the later effects of the folding was microscopic faulting throughout the schist mass and in some of the marble beds, producing an eastward-dipping slip cleavage, and also the formation of secondary mica along these fault planes or the transfer of graphite to them. Faulting on a large scale also occurred, thrusting whole series of beds up or down in places a quarter of a mile. Various longitudinal and transverse strains, compressive and tensional or torsional, formed various systems of joints.

6. As soon as the rock surface emerged from the sea atmospheric erosion began to operate upon it. The streams, taking advantage of joints, made transverse cuts in the schist folds and also eroded longitudinally in the ruptures along anticlinal axes. In the course of time erosion reached the marble beds, forming both anticlinal and synclinal valleys; and the solubility of the marble by carbonic acid greatly accelerated the process. In places the entire set of marble beds was eroded, exposing the underlying dolomite, as shown on the map. ${ }^{1}$

7. The region probably suffered again during the crustal movements which occurred at the close of Devonian and Carboniferous time. The metamorphism of the conglomerate of Bird Mountain, which lies only 3 miles west of West Rutland, in the Taconic Range, on the Berkshire schist, and contains pebbles of calcareous quartzite and dolomite, may have to be assigned to one of these movements. ${ }^{2}$ The trap dikes described on page 72 afford tangible evidence of a crustal movement which affected all the formations, but was unaccompanied by metamorphism. This movement produced many fractures in the marble beds.

8. To a still later date, the close of Cretaceous time, some geologists assign the general elevation of the region to an altitude that is considered greater than the present height of the Vermont Valley above sea level; the erosion of the lower part of the valley must therefore have taken place subsequent to this elevation. To the several postOrdovician crustal movements is probably to be attributed the shattering of so many beds of otherwise good marble.

\footnotetext{
1 The process and effects of erosion in western Vermont are more fully elucidated in Taconic physiography: Bull. U. S. Geol. Survey No. $272,1905$.

2 Dale, T. N., A study of Bird Mountain, Vermont: Twentieth Ann. Rept. U. S. Geol. Survey, pt. 2, 9100, pp. 15-23.
} 
9. Of comparatively recent geologic date was the covering of the entire region by the continental ice sheet, which moved across it, according to the striated ledges, in south, south-southeast, southeast, and east-southeast directions, gouging, scratching, polishing, and potholing the exposed marble and other beds, strewing the hillsides and valleys with bowlders and leaving mounds of gravel. Some furrowed and polished marble surfaces are shown in Plates $\mathrm{XV}, B$, and XVI, $A$.

10. The glacier in its retreat so blocked the natural drainage of the valleys into Hudson River and Lake Champlain as to dam the rivers swollen from the thawing ice and to fill the valleys of the marble belts with lakes. These lakes deposited finely stratified clay upon the glaciated marble surfaces, protecting them from further erosion. (See Pl. XVI, A.) They also formed the horizontal sand terraces and shore lines which are so conspicuous in Dorset Hollow, Manchester, and Sunderland at the 1,000,1,100, and 1,200 foot levels.

\section{GEOLOGIC PRINCIPLES GOVERNING THE MARBLE BELTS.}

The following paragraphs treat of those elementary geologic principles a knowledge of which should underlie the quarrying of marble in the Taconic region. Such knowledge is even more important than that required to qualify a mining engineer in the anthracite region of Pennsylvania, for the stratigraphy of the marble in this region of folds is quite as complex as that of the Pennsylvania coal beds and the difficulties are much enhanced by the intense metamorphism which the beds have undergone.

\section{CONTINUITY OF THE STRATUM.}

Other things being equal, the same kind of marble is more likely to be found along the same bed than across adjacent beds for the reason that marine sediments of the same sort are generally formed at the same time over considerable areas, but are more apt to vary from time to time at the same place. The distance of a few feet across the stratum represents a considerable number of years, and therefore much greater probability of change of character than the same distance along the stratum. Of course there are changes along the stratum, due to contemporary changes of sediment, as one stream may carry more sand into the ocean at one point while another, a mile or two away, may be discharging more clay at the same time. On the other hand, geologic history may in smaller cycles repeat itself. Similar conditions of erosion and sedimentation may after many years recur at the same place and result in similar beds. The marble series illustrates these facts very well. Where a bed has been elongated or faulted the original continuity has been modified or interrupted. 


\section{FOLDED BEDDING.}

The western Vermont marble region, as shown by the general and detailed sections (Pls. II, III), is one of folding, so that horizontal beds are exceptional. They are only to be expected at the bottoms of the troughs or the tops of the arches of the folds, and therefore can hardly retain their horizontality for any great distance. An idea of the folds of the region can be obtained by observing the minute folds in the little grayish dolomitic beds within the clouded marbles. These small folds, as it were, epitomize the large ones. The folding of the strata is the fundamental character of the region and the primary factor controlling the vertical and horizontal distribution of the marble. If a series of beds plunges in at one point it should emerge at another, for it is but part of a fold, and for the same reason if a series of beds emerges at one point, unless it is at the actual offshore beginning of the formation or unless faulting has occurred, the beds should be found to the east or west going down again and completing

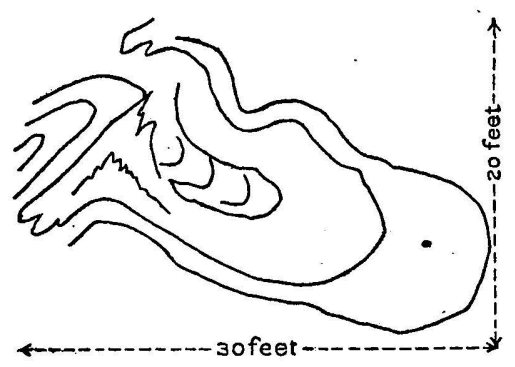

FIGURE 10.-Bottle-shaped fold in disused marble quarry 3 miles south of Brandon. the original arch of the fold. The whole marble region should be thought of as originally corrugated on a large scale, the corrugations running in a north-northeast or north-northwest direction.

\section{CHARACTER OF THE FOLDS.}

The folds are rarely symmetrical-that is, with both sides equally inclined-and the angles of a symmetrical fold may vary from a few degrees away from the horizontal to the vertical. Folds are known as open or close. A close normal fold is one shaped somewhat like a letter $U$, with both limbs parallel and pressed together. Most of the folds in the Taconic region are made up of minor folds. This is shown on a large scale in the east limb of the anticline exposed in the West Rutland quarries (fig. 17, p. 122, and Pl. XII). The limbs of close folds in this region are in places so compressed as to resemble in cross section the longitudinal section of a bottle. A small fold of this kind near Brandon is shown in figure 10. When such a fold makes up a ridge or hill and stands erect a syncline may easily be mistaken for an anticline.

\section{LATERAL INCLINATION OF THE FOLDS.}

Folds of the various sorts described may be laterally inclined at any angle. Those on Green Peak (fig. 14, p. 103) have horizontal axial planes. The bottle-shaped marble fold shown in figure 10 is 
inclined $20^{\circ}$. The compressed marble folds shown in figure 11 have axial planes dipping about $50^{\circ}$.

\section{PITCH OF THE FOLDS.}

One of the more important economic features of a fold is the pitch of its axis. In the region here discussed this pitch will be found to be alternately north-northeast and south-southwest, or northnorthwest and south-southeast, or north and south, according to the general direction of the corrugation of the portion of the belt containing the fold. The degree of pitch is generally small, $5^{\circ}$ to $20^{\circ}$, but it may be greater. The practical effect of the pitch is that in working along the strike of a series of beds the same bed will be found at greater or lesser depth. A syncline at the Albertson quarry pitches alternately north and south. (See p. 123.) The termination of the West Rutland anticline both on the north and south (Pls. I, IV) is presumably due to pitch, the marble fold pitching under the overlying schist mass. The low southerly dips in the northern part of the Dorset Mountain mass are evidently due to pitch. The cause of pitching folds is not perfectly understood.

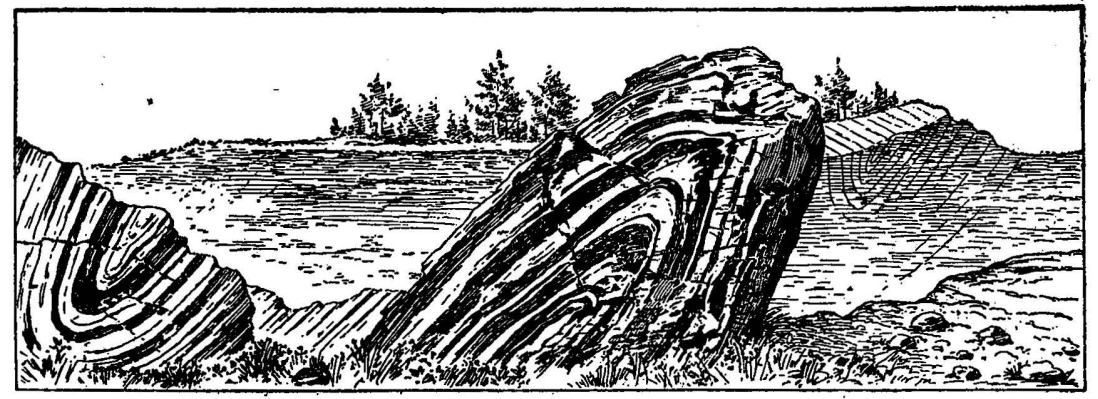

FIGURE 11.-Overturned marble folds with eastward-dipping axial planes at Lenox, Mass., north side. The dark layers, really yellowish, are due to oxidation of iron. The folds are thickened at the apex and drawn out, and some faulting has occurred in the upper beds of the anticline.

ELONGATION AND FLOWAGE.

The weight of nearly half a mile of superincumbent schist upon the calcareous sediments at the time of the folding and the intensity of the compressive force which produced the folds were both so great that the calcareous beds became effectually plastic. Had this compression occurred with less overlying weight the beds would have either been simply folded or possibly brecciated or granulated. The result of this plasticity is seen in the elongation and thinning of the beds along the limbs of the folds and their thickening at the ends, as in the marble folds shown in figure 11. To this process the variation in the thickness of the marble beds is largely due. The 
process did not stop here but in places resulted in actual flowage. The extremely extended compressed folds on Green Peak (fig. 14) and such structures as that in the center of the bottle-shaped fold near Brandon (fig. 10) and that near the Owls Head (Pl. XVI, B) can be explained in no other way. As the flowage of marble under compression has been demonstrated experimentally (p. 17), the probability that the crystallization of the limestone beds into marble occurred during an early stage in the process of folding does not involve any theoretical difficulties. The economic bearing of this feature of the marble in the Taconic region is that wherever the folding has been very intense thinning, thickening, and flowage are to be expected in the marble beds. This is probably the greatest irregularity to be met with in a stratified calcareous rock.

\section{PINCHING OUT OF BEDS.}

At the True Blue quarry (p. 125), there is a fine exposure of an unusual occurrence in the marble belts. (See Pl. XV, A.) A 15-foot bed of alternating graphitic dolomite and calcite marble stops abruptly along an eastward dipping cleavage plane, but a 3-foot bed of black dolomite veined with white calcite and quartz which forms the upper part of the 15-foot bed resolves itself into a series of lenses that continue in the marble in the direction of the dip of the original bed and have been found in the tunnel below on the right. The first of these lenses is about 3 by 2 feet. It is more probable that this change of a stratum into a series of lenses is the result of the elongation and pinching out of the bed rather than of diminished sedimentation or of dolomitization. The continuation of the rest of the 15-foot bed, consisting of banded dolomite and calcite marble, has not yet been found. If its disappearance is due to faulting the bed should reappear at the west.

This illustrates what may happen to a bed of dolomite within a series of marble beds. The fact that the position of a missing bed may be fixed by that of a series of lenses is a principle which may be very helpful in solving certain practical stratigraphic problems.

\section{RELATION OF MARBLE TO SCHIST.}

The relations of the marble to the overlying schist have been shown in the general sections, Plate II, and in the detailed sections on Plate III.

The first inference from the parallelism of the two formations is that wherever the base of the schist occurs the marble should immediately underlie it.

The next inference is that the strike and dip of the bedding of the schist at its base indicate approximately those of the underlying marble. 
These inferences are of economic importance wherever the marble along the marble-schist boundary is covered. Thus on the west side of the West Rutland anticline, opposite the quarries of the east side, the marble is covered, but unless a fault intervenes, of which there is no indication, the probable dip of the marble can be determined by ascertaining that of the schist.

\section{BEDDING AND CLEAVAGE IN SCHIST.}

As the bedding of the schist is locally obscured by slip cleavage and the two foliations in many places dip in opposite directions, cleavage is easily mistaken for bedding. The two features can be distinguished by the following criteria:

Slip cleavage is generally, although not invariably, in straight or very slightly undulating planes; bedding is in small or minute plications, in places even of microscopic size, and is generally crossed by the cleavage at various angles.

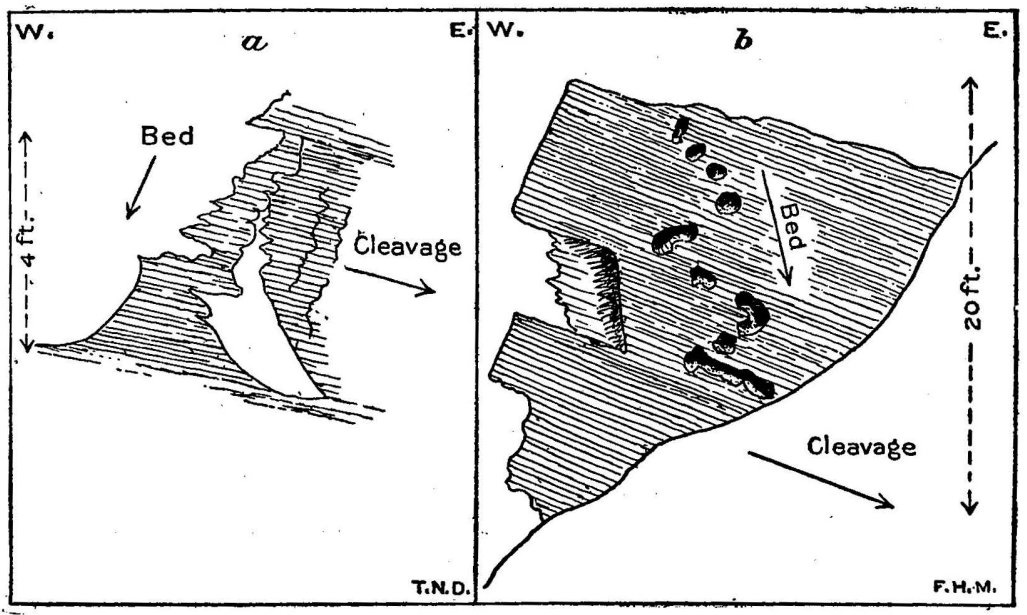

FIGURE 12.-Bedding and cleavage in schist. $a$, On Dorset Mountain; $b$ (by F. H. Moffit), on Bear Mountain, Sandgate. In $a$ a columnar plicated bed has been isolated by the erosion of a bed which may have been slightly calcareous. In $b$ the course of the bedding is shown by cavities 6 to 8 inches wide formed by the partial erosion of a calcareous bed.

Bedding is determinable by the course of small calcareous or quartzitic beds (not to be confounded with quartz veins, which occur in both cleavage and bedding foliation). In those rare localities where the cleavage foliation has been subsequently plicated so as to resemble bedding the evidence of such small beds of different sediment is very necessary.

One of the most interesting localities where these phenomena may be studied in the Taconic region, described and illustrated in 1892 $49311^{\circ}-$ Bull. 521-12-6 
and $1893,{ }^{1}$ is opposite (west of) the eastern West Rutland quarries. (See Pl. IV and p. 70.) The marble which crops out on the line of the strike south of West Rutland, about the Eastman and adjacent quarries, is here covered by meadows. A line of conspicuous schist ledges forms the base of the hill (Taconic Range) west of the highway, and the schist appears to dip east and thus to underlie any marble that might be concealed by the meadows, but closer inspection shows low westward-dipping calcareous beds in the schist crossing the deceptive eastward-dipping cleavage and indicating that the marble of the meadows dips under the schist and should be found under the schist with that dip. As this eastward-dipping cleavage in parts of these ledges is plicated, the usual criterion as to bedding fails here. The structure of the schist at this locality and the probable structure of the concealed marble are shown in section F, Plate III. Other illustrations of the same principle in Sandgate and Dorset are given in figure $12 .^{2}$

At a point $1 \frac{1}{4}$ miles northwest of Proctor station similar relations exist between the marble and schist. The schist has a cleavage dipping $65^{\circ} \mathrm{E}$., but its bedding is horizontal or dips at a low angle to the west. On the other hand at a point $1 \frac{1}{2}$ miles southwest of Pittsford station marble and schist are in contact, both dipping $40^{\circ}$ E. and the cleavage and bedding of the schist being parallel.

\section{CLEAVAGE IN MARBLE.}

Some of the structural features of the schist recur in the marble. The planes laden with graphite which intersect the marble beds at the Albertson and True Blue quarries (p. 123; Pls. V, $A$, and VIII, $B, b$ ) are planes of slip cleavage. As graphite is here hardly a secondary mineral its abundance along the cleavage planes may be accounted for by transfer during the compression and its attendant metamorphism. The planes dipping $30^{\circ} \mathrm{E}$. crossing the $80^{\circ} \mathrm{W}$. plicated beds at the Landon quarry in Pittsford are possibly planes of slip cleavage also. But there are other parallel close fracturess crossing the marble beds at many points and known as "reeds" by quarrymen which are not so clearly slip cleavage. They may be close joints due to some later crustal disturbance. These are rather common on Dorset Mountain and generally dip eastward, as, for example, at the Imperial and White Stone Brook quarries (pp. 108, 109). At the abandoned quarry about half a mile south of the Proctor quarry the marble beds dip $70^{\circ} \mathrm{E}$.

\footnotetext{
1 Dale, T. N., Plicated cleavage foliation: Am. Jour. Sci., 3d ser., vol. 43, 1892, p. 317; The Rensselaer grit plateau in New York: Thirteenth Ann. Rept. U. S. Geol. Survey, pt. 2, 1893, pp. 321-324.

2 The whole subject of the relation of cleavage and bedding in schist is more fully explained in the following papers: Pumpelly, Raphael, Wolff, J. E., and Dale, T. N., Mon. U. S. Geol. Survey, vol. 23, 1894, pp. 139-140, 149-154, 158, 188; Dale, T. N., On the structure of the ridge between the Taconic and Green Mountain ranges in Vermont: Fourteenth Ann. Rept. U. S. Geol. Survey, pt. 2, 1894, pp. 537, 538, 546; Structural details in the Green Mountain region and in eastern New York: Sixteenth Ann. Rept. U. S. Geol. Survey, pt. 1, 1896, pp. 559-568; Slate deposits and slate industry of the United States: Bull, U. S. Geol. Survey No. 275, 1906, pp. 24, 25.
} 
but the reeds $20^{\circ}$. Of course, wherever the marble is very "reedy" it is valueless.

JOINTING.

Certain joints or systems of joints characterize the marble beds generally; others, to be considered later, are related to the trap dikes or are altogether irregular joints. The most prevalent set of joints strikes $\mathrm{N}$. $65^{\circ}-80^{\circ} \mathrm{W}$. with its complementary set $\mathrm{N}$. $10^{\circ}-20^{\circ} \mathrm{E}$.; another set strikes $\mathrm{N}$. $75^{\circ}-80^{\circ} \mathrm{E}$. with its complementary set $\mathrm{N}$. $10^{\circ}-20^{\circ} \mathrm{W}$. There are also two less common diagonal sets striking N. $30^{\circ}-55^{\circ} \mathrm{E}$. and $\mathrm{N}$. $30^{\circ}-35^{\circ} \mathrm{W}$., the former of which is probably related to dikes.

\section{IRREGULAR FRACTURES.}

Some fractures, like those shown in figure 19 (p. 129), are so irregular that it may be infersed that they were produced by an exceptional crustal movement.

FAULTS.

The faults along the intermediate range and on Pine Hill are shown on the map (Pl. I) and on sections I and II, Plate II, and section G, Plate III, and are explained on pages 67-68. Faulting has also been regarded as possible between South Dorset and the Owls Head quarries (p. 93) and in Sunderland near the Dyer quarry. Wherever in quarrying operations such a dislocation is encountered the first thing to do is to ascertain the direction of the thrust and then the amount of vertical or lateral displacement so as to know where to look for the continuation of the lost bed or beds. For these purposes some core drilling may be necessary. Wherever in the marble belts the folding is very sharp faulting is likely to occur. The displacement in many such faults may, however, amount to only a few feet.

\section{DIKES AND THEIR EFFECTS.}

The subject of dikes and their effects has been dwelt upon already (p. 72) and illustrated in Plate $\mathrm{X}, B$. The dikes are usually associated with close jointing in the marble, on one or both sides, and in some places with two sets of such joints. Therefore the presence of a dike should be regarded as an indication of close jointing in the marble in proximity to it. The dikes also send out small ramifications into the marble. It is the practice, therefore, to allow a generous unworked margin in the neighborhood of a dike. The most prevalent course of the dikes is N. $60^{\circ}-70^{\circ}$ E.; the next N. $25^{\circ}-40^{\circ}$ E. A few run about east and west.

The marble which underlies the dikes at the New York quarry, on Dorset Mountain (p. 110), which dip $65^{\circ}$, has no close joints, but at the White Stone Brook quarry, not far away, there are close joints on the upper side of the dike and an intersecting set on the under 
side (p. 108). In view of the origin of these dikes it is hardly necessary to state that they can not be eradicated. Where a stone crusher is available they furnish the best material for quarry roads. Owing to its considerable content of magnetic iron the dike rock is apt to deflect the magnetic needle. Surveyors therefore need to be cautious in running lines near them.

\section{EROSION OF FOLDS.}

The importance of erosion in the history of the region has already been pointed out. As all the marble strata which crop out at the surface must once have been horizontal, and as they can not be put together in imagination as blocks in their original position, and as in exposed cross sections the beds are found forming arches and troughs, their present fragmentary condition is manifestly to be attributed to the truncation of folds by erosion. The correctness of this view is corroborated by the presence of the schist formation on the uneroded portions of the marble folds.

At the West Rutland quarries of the east side the first question which suggests itself to a structural or economic geologist is as to the location of the continuation of the beds whose edges border the quarries and form the hillside. If these beds are part of an eroded fold, the same beds should recur, in inverse order, between the quarries and the schist ledges on the west. The arch which joined the east and west limbs of the anticline has been removed by erosion, as shown in the sections. The exposures to the north and south are insufficient to enable us to reconstruct the minor folds in the eroded arch, but that it is an anticline is evident south of West Rutland, where some of the beds of the east side recur. The practical outcome of such schematic reconstruction of the marble folds is to facilitate the search for those remnants of them which are concealed by gravel, sand, or clay, of glacial and postglacial date. The principle of the erosion of folds should be applied to the explanation of every considerable exposure of marble beds in this region.

\section{UNDERGROUND SOLUTION.}

The formation of caves in limestone and marble regions by the solution of underground water carrying carbonic acid of atmospheric origin, if not also organic acids of plant origin, is a familiar occurrence. Such caves are not uncommon in the marble belt of the Taconic region. The best known of them is that on Green Peak ${ }^{1}$ (see Pl. I, point C), which is in marble near the overlying schist, 
about on the 2,400-foot level. Exploration of it is reported to be dangerous owing to the presence of carbonic-acid gas. A little over a mile farther north, on the west side of the north-south part of Dorset Mountain, at the contact of marble and schist, near the 1,700foot level, a brook flowing west toward Dorset Hollow disappears in a cave. Nearly a mile west of this and a little east of the road corner a small brook, known as Cold Brook from its very low temperature in midsummer, passes out of a dolomite or marble cave 600 feet north of the bed of the brook coming down from the other cave. This brook is usually dry.

The process of cave formation by solution is finely shown on a small scale in the wall of the Florence No. 1 quarry in Pittsford (Pl. XVII) and also on the walls of the disused Proctor quarry. The water gains admittance along steeply inclined bedding planes and thence passes along intersecting joints, forming a series of small caves along both sets of planes. Although some of the larger caves may be helpful in locating marble beds, these smaller ones are a serious hindrance in channeling. Their occurrence can not be foretold.

\section{EFFECTS OF GLACIATION.}

The gouged, striated, and polished marble ledges, their large potholes (p. 126), the sand, stony clay, and gravel which conceal large parts of them, and the abundant bowlders are the effects of glacial erosion. In view of the great thickness of the ice sheet under which the region was buried these mechanical effects are not surprising. Plate XVI, $A$, shows a broad glacial gouge at a now disused quarry in Pittsford, and Plate XV, $B$, shows a recently exposed striated and polished surface of graphitic marble near the Florentine quarry in Pittsford.

\section{PROTECTION BY CLAY BEDS.}

Where the glacial deposits have been removed from the marble beds or where the marble is covered by sand and gravel, it is generally more or less weathered to a depth of 20 feet. But where the marble is covered by pebbly glacial clay (till) or by beds of clay deposited in a postglacial lake, the imperviousness of the clay has protected the marble from the action of surface water. In such places fresh marble can usually be obtained within a few inches of the surface, as at the Riverside quarry in Proctor and at the quarry shown in Plate XVI, $A$. The glaciated marble surface shown in Plate $\mathrm{XV}, B$, is also very fresh. The imperviousness of the clay is shown by the preservation of the most delicate striation and the polish, which, however, soon disappear on exposure to the weather. 


\section{THE MARBLE BEDS.}

From the detailed sections made at the quarries and the core-drill records obtained the general facts as to the succession and thickness of the marble beds can be determined. These facts will be grouped geographically.

\section{EAST SIDE OF WEST RUTLAND ANTICLINE.}

Measurements made by the writer with a steel tape of the beds between the east wall of the upper Gilson quarry and the probable line of contact between the marble and the schist on the east give the following succession. The schist contact is about 248 feet east of the east side of the red schoolhouse on the brow of the ridge.

Section of marble beds between Gilson quarry and schist contact.

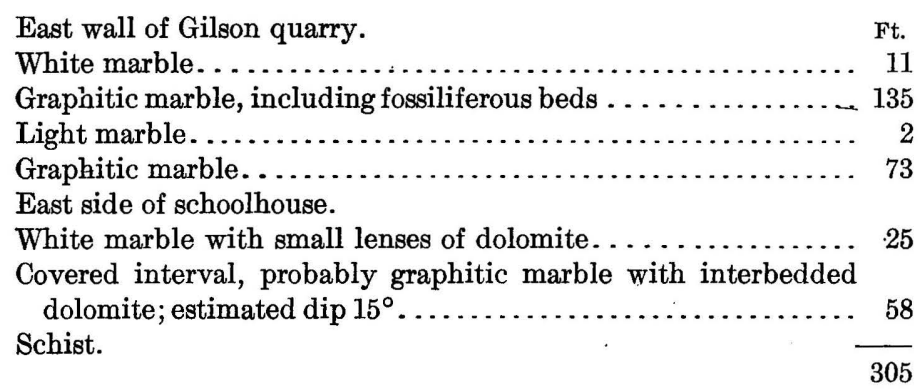

These measurements generalized and added to those obtained from core-drill records and other measurements made by the Vermont Marble Co. in its quarries give the following succession for the east side of the West Rutland anticline, beginning at the schist:

Section of marble beds on east side of West Rutland anticline.

\begin{tabular}{|c|c|}
\hline Marble varieties. & Series. \\
\hline 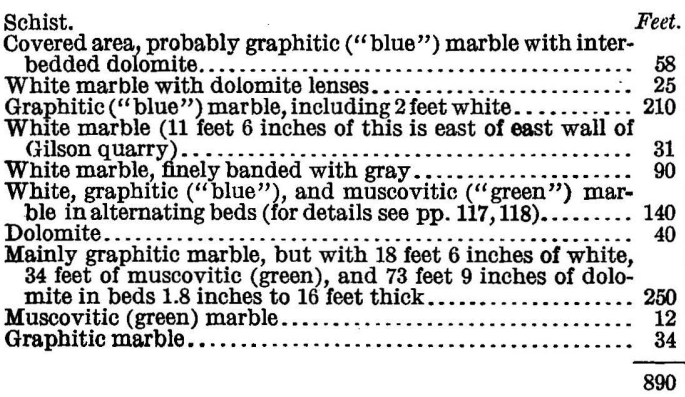 & $\left\{\begin{array}{l}\text { Upper graphitic series (293 feet). } \\
\text { Mixed marble series (261 feet). } \\
\text { Lower graphitic series (296 feet). }\end{array}\right.$ \\
\hline
\end{tabular}


The True Blue quarry is situated in the upper graphitc series of the foregoing table - that is, in the unquarried beds on the ridge east of the West Rutland quarries. The beds at this quarry are approximately these:

Section of marble beds at True Blue quarry.

Schist. Feet.

Graphitic marble, about..................

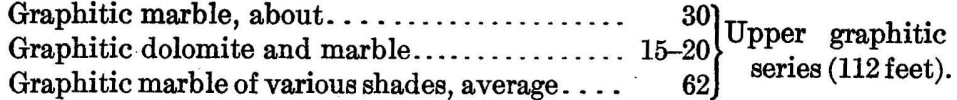

Graphitic schist...................... 40

At the Albertson or Esperanza quarry the following section is exposed:

\section{Section of marble beds at Albertson quarry.}

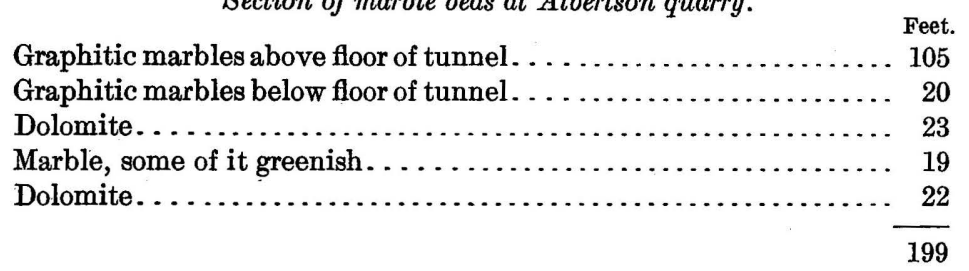

As the schist boundary is a considerable distance east of the east wall of the Albertson quarry, and as the series exposed at the Truo Blue quarry only measures about 112 feet from the schist down, the series at the Albertson quarry either includes but a part of the True Blue section or else is entirely below it. The absence of the 40-foot schist bed here would have to be accounted for thus, or else by a change in sedimentation in the space of a mile along the strike. The open syncline of the Albertson tunnel is probably a continuation of one of the minor folds at the True Blue but lower down.

It will be noticed that the graphitic beds of both the True Blue and the Albertson quarries belong to the upper graphitic series in the West Rutland section.

\section{WEST SIDE OF WEST RUTLAND ANTICLINE.}

The most complete exposure on the west side of the West Rutland anticline is at the Eastman quarry, about $1 \frac{1}{2}$ miles nearly south of the West Rutland station, where, however, owing to a minor westward overturned fold in the western half of the anticline the beds dip east at the surface. (See section E, Pl. III.) The schist boundary on the west is covered by pasture land. Graphitic marble is exposed for 100 feet from a point 50 feet west of the west edge of the quarry. If a dip of $35^{\circ} \mathrm{E}$., like that at the quarry, is assumed for this marble and also for the 50 feet covered by turf, the series generalized is as follows: 
Section of marble beds at Eastman quarry.

Graphitic marble, exposure 100 feet wide, at $35^{\circ} \ldots \ldots \ldots \ldots \ldots . \quad 57$

Graphitic marble, covered area, 50 feet, at $35^{\circ}$. Of this 28 feet 22

feet has been found by core drilling from the quarry to be graphitic marble.................................. 28

West edge of quarry.

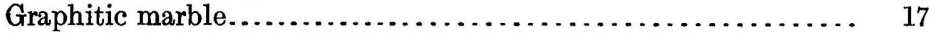

Total graphitic marble.......................... 102

Assorted marbles, cream colored, muscovitic (green), white, etc.

(for details see p. 113)............................. $\quad 73 \frac{1}{3}$

East edge of quarry.

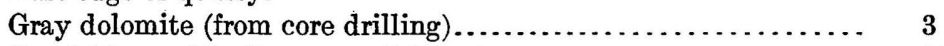

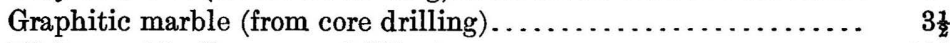

White marble (from core drilling) $\ldots \ldots \ldots \ldots \ldots \ldots \ldots \ldots \ldots, \quad 13 \frac{1}{2}$

$195 \frac{1}{3}$

In the gravel pit north of the new Roman Catholic Church and cemetery about a quarter of a mile west-southwest of the West Rutland station a probable outcrop of graphitic marble has been exposed with the normal strike of the West Rutland belt, N. $25^{\circ}-30^{\circ} \mathrm{W}$., and dips on the east of $30^{\circ} \mathrm{E}$. and on the west of $60^{\circ}-70^{\circ} \mathrm{W}$. The nearest schist outcrop and the probable boundary between marble and schist is about 400 feet west of this graphitic marble.

If the space between the two rocks here is all marble and the dip is $60^{\circ} \mathrm{W}$. the thickness of the marble would be 320 feet, or, roughly, 300 feet. If the graphitic beds in and west of the Eastman quarry are regarded as part of this series, it would only be necessary to add to these beds the rest of the beds in the Eastman quarry in order to obtain an estimate of the series on the west side of the West Rutland anticline as far as exposed or indicated. The succession would be as follows, beginning on the west:

Section of marble beds on west side of West Rutland anticline.

Graphitic marble, possibly with some interbedded dolomite.... $\quad 300$

Cream-colored, white, muscovitic, and other marbles of Eastman

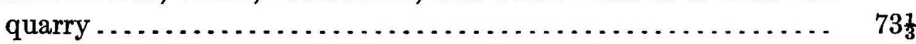

Gray dolomite (from core drilling east of quarry) ............ 3

Graphite marble (from core drilling east of quarry) ........... $3 \frac{1}{2}$

White marble (from core drilling east of quarry) $\ldots \ldots \ldots \ldots \ldots .13 \frac{1}{2}$

$393 \frac{1}{3}$

Inasmuch as the graphitic beds on the east side of the West Rutland anticline aggregate 293 feet (p. 86), the prognostication of 300 feet for the west side is but very little out. Furthermore, inasmuch as the marble of the Eastman quarry aggregates only 111 feet there should be, to judge from the succession on the east side of the anticline, some 200 feet more of assorted marbles east of the Eastman quarry unless some structural feature not shown at the surface intervenes to cut them off. 
That the marble of the Eastman quarry does not correspond bed for bed to that exposed in the quarries on the east side of the anticline is probably to be attributed to minor changes of sedimentation in the distance of a mile along the strike and a quarter of a mile from east to west. A little more clayey sediment in the sea at one point than another would suffice to make the difference between a muscovitic (green) marble and an almost white one.

\section{PROCTOR.}

There is no place in the marble belts where the need of a large-scale topographic map accurately showing all the surface details, coupled with ample time for geologic investigation, is more striking than the area extending from Otter Creek on the east three-fourths of a mile to the schist ridge on the west and a mile from north to south, containing the village of Proctor. A complex topography of more or less wooded little hills and hollows and an irregular network of streets coincide here with an area of complicated stratigraphy. The main features, however, are the schist ridge on the west under which the marble dips and the dolomite on the east dipping under the marble, as shown at the Proctor or Sutherland Falls quarry. The marble belt thus bounded is here from 1,650 to 2,200 feet wide. The general structure is shown approximately in sections $\mathrm{G}$ and $\mathrm{H}$, Plate III.

The marble beds of the Proctor and Columbian quarries and of a disused quarry between these belong apparently to the base of the marble series, as do also the beds of the Riverside quarry, 2 miles south of Proctor. At the Proctor quarry the thickness exposed is less than 200 feet, for the beds are doubled over in a minor anticline on the west. At the disused quarry on the knoll one-third mile to the south marble about 185 feet thick is exposed. At the Riverside quarry marble measuring 85 feet is in sight and 170 feet more have apparently been crossed by core drilling westward, giving a total of about 250 feet. As the dolomite series and the overlying marble a little farther south dip in the opposite direction from those in the quarry, there is probably a syncline here and the beds prospected east of the quarry may be mostly the same as those in the quarry.

West of the Proctor quarry the marble dips under an overlying mass of dolomite 840 feet wide which extends to the pond. Its thickness depends on the number of folds and the inclination of their sides. The dips range from $35^{\circ}$ to $75^{\circ} \mathrm{E}$. If there is one syncline and one anticline in this mass the thickness would be about 264 feet, which, to judge from that of the corresponding dolomite in the Pittsford section, is probably not far from correct.

The conspicuous marble knoll half a mile south of Proctor and north of the Columbian quarry (see map, Pl. I) presents an interesting problem. Its probable structure is shown in section $\mathrm{H}$, Plate III. 
Its west side is pretty clearly an anticline with an almost vertical west limb and a narrow horizontal or nearly horizontal top and core, followed on the east by a compressed syncline overturned to the west, the upper beds of the dolomite overlying the marble with easterly dip, as at the Proctor quarry. In this dolomite a test pit has exposed a graphitic dolomite like that of the prospect 2 miles north of Proctor (p. 128). Although the marble of this knoll apparently belongs to the Proctor quarry line of beds, yet its strike is in line with the marble beds of the Shangrow quarry and with the pond west of the Proctor quarry. Furthermore, in the dolomite east of the knoll there is a small strip of white marble about 20 feet wide cut off by dolomite on the south, which is in line with the marble of the disused quarry in the village and of the Proctor quarry. There may be a lateral dislocation here along a fault line passing between the north side of the marble knoll and the dolomite cliff on the next knoll north; and this 20 feet of marble may be a small bed in the basal dolomite. If there is such a dislocation the intermediate dolomite which lies west of the Proctor quarry passes west of the marble knoll and is covered by drift. As a large part of the top of the knoll is covered by vegetation, it is uncertain whether the intermediate dolomite is represented in the synclinal part of the knoll. Hence the interrogation mark over that part of the section. The entire thickness of the marble beds here approximates 264 feet, but if they were quarried in the mass across the folds from east to west it would measure not far from 740 feet.

West of the intermediate dolomite, which at any rate forms the hill west of the Proctor quarry, is an upper set of marble beds well exposed in the now disused Shangrow quarry and other neighboring quarries and at several points in the village. This marble is mostly graphitic and in places finely banded. The space between the dolomite at the pond and the schist boundary on the west is roughly about 600 feet and that between the marble knoll three-fourths of a mile south of the Proctor quarry and the schist boundary, after deducting 272 feet for the covered dolomite, is about 500 feet. The structural relations call for an easterly inclined syncline next to the dolomite and a normal anticline west of it. If these folds were compressed and vertical the space at the pond would admit of beds 200 feet thick, but as the beds dip from $55^{\circ}$ to $65^{\circ} \mathrm{E}$. on the east side and $25^{\circ}$ to $45^{\circ} \mathrm{W}$. on the west their thickness can hardly exceed 150 feet. If the folds are steeper west of the steep marble knoll to the south their thickness might be 150 feet. The greatest thickness of the graphitic beds exposed at any one quarry is 135 feet. The reason for the fault shown in section $G$ will appear after considering the Pittsford section. (See p. 91.)

These graphitic marbles extend to the schist ridge, where they dip west under the schist, the plicated bedding of which also dips west, 
although crossed by a more conspicuous eastward-dipping slip cleavage. The presence of at least one anticline in the basal dolomite at Proctor is shown by the $50^{\circ}$ westward dip of the dolomite back of the Y. M. C. A. Building and the town hall. This dip becomes $75^{\circ}-80^{\circ}$ W. a few hundred feet farther south, back of the post office, whereas the prevalent dip west of these points is $70^{\circ} \mathrm{E}$.

The marble of the entire Proctor section thus appears to consist of the following members, so far as the data obtained indicate, beginning on the west and at the top.

Schist.

Section of marble beds at Proctor.

Graphitic marble of Shangrow and other neighboring quarries, with some interbedded dolomite ..................... $\quad 150$

Dolomite (knoll west of Proctor quarry) . .................. 264

Marble, bluish white, clouded . . . . . . . . . . . .

Dolomite.

Feet.

$586-678$

PITTSFORD.

In Pittsford the marble belt widens out to 0.7 mile west of Fowler and to 0.9 mile east of the Florentine quarry. The first inference from this widening is that the schist has been eroded from a wider surface of the marble belt and that its structure consists of minor folds. The difficulty in obtaining satisfactory estimates of thickness in this locality is great. A view across the marble belt here is given in Plate IX.

At the Florentine quarry, where the contact between schist and marble is visible, the graphitic upper part of the marble beds is well exposed and measures about 150 feet.

At the old Hollister quarry, beginning at a point about 127 feet west of the west wall of the quarry and counting eastward and downward, the following section has been made out:

Section of marble beds at Hollister quarry.

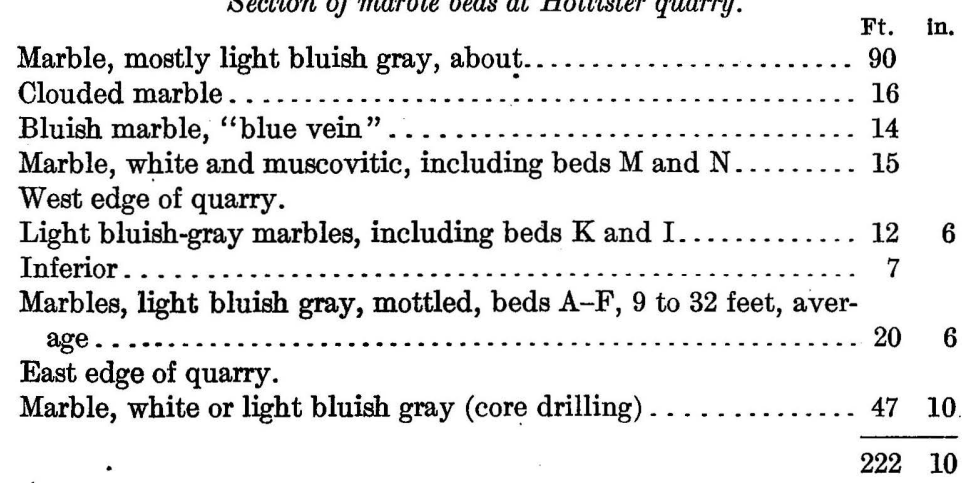

East of these beds there are 146 feet of strata to a dolomite. If these are all marble and dip not higher than $50^{\circ}$ they would amount to 
a thickness of 112 feet. In view of the uncertainties these strata are not counted. As beds A to F measure 32 feet at a depth of 175 feet but only 9 feet at the surface, and $\operatorname{dip} 87^{\circ} \mathrm{E}$. on the east side but $90^{\circ}$ on the west, they might be regarded as the core of an anticline, but the quarrymen report that the character of the marbles does not indicate duplication here. The entire series is so thick, however, as to point strongly to such duplication.

At the Florence No. 1 or Hogback quarry, besides the 85 feet of pale-gray mottled marble exposed in the quarry, core drilling has crossed 110 feet of similar marbles on the west and 50 feet on the east followed by 20 feet of white near the dolomite. The succession here, beginning on the west, is as follows:

Section of marble beds at Florence No. 1 quarry.

Marble west of quarry crossed by core drilling, 110 feet; if dipping $70^{\circ}$ measures . . . . . . . . . . . . . . . . . . . . . . . . . . 102

Light-gray clouded marbles exposed in quarry ............... 85

Similar beds crossed by core drilling east of quarry, 50 feet at $70^{\circ} \ldots, \quad 47$

White marble crossed by core drilling east of quarry, 20 feet at $70^{\circ}$.. $\quad 18$

252

Dolomite east of above beds, 270 feet at $70^{\circ} \ldots \ldots \ldots \ldots \ldots \ldots \ldots 252$

Outcrops of light marbles east of dolomite, 100 feet at $70^{\circ} \ldots \ldots \ldots .93$

Dolomite.

Another estimate of the lower part of the marble of the Pittsford section was obtained at the Pittsford Italian and Florence No. 2 quarries. At the Florence No. 2 quarry there are 45 feet of lightgray mottled marbles, including a 9-foot bed of dark-gray marble, dipping $82^{\circ}$. Drilling has been done to a point 170 feet east of the quarry, showing the same marbles extending almost to the underlying dolomite. The succession at both quarries is as follows:

Section of marble beds at Florence No. 2 and Pittsford Italian quarries.

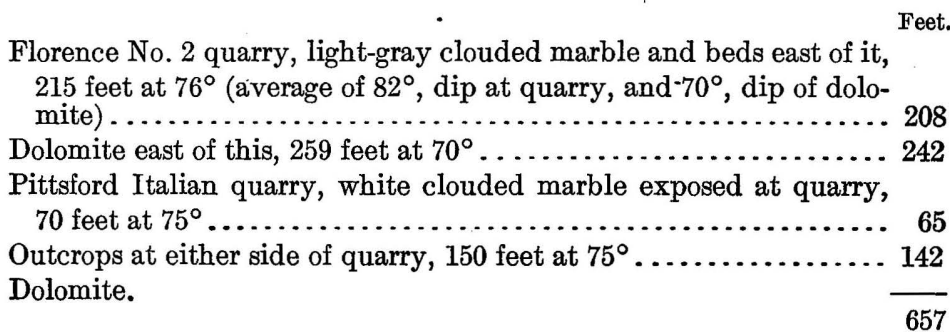

At the Landon quarry about 80 feet of mottled light-gray marble has been exposed, belonging near the base of the Pittsford section. 
From these several sets of measurements and estimates the marble of the Pittsford section appears to consist approximately of the following members, beginning at the top and west:

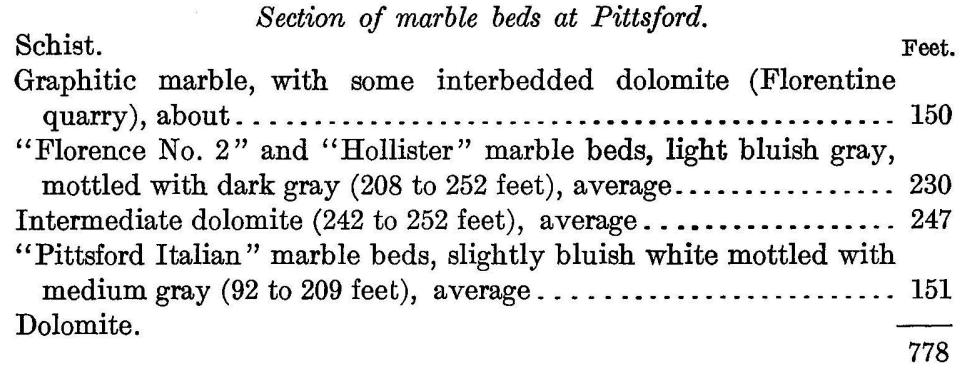

SOUTH DORSET.

The marbles of South Dorset not only differ texturally and mineralogically from those already described, being generally coarser and containing actinolitic beds, but they appear to be structurally isolated from the marble beds on Dorset Mountain and. Green Peak by a fault or faults whose course is concealed. The marble in the quarries about a mile northeast and 500 feet above the Norcross-West South Dorset quarries lies in nearly horizontal folds of unusual character, as shown in figure 14 and on page 102. If such horizontal or low-dipping folds have been produced by extreme lateral compression and a subsequent erection of folded series so as to give the beds a general dip across the folds of about $80^{\circ} \mathrm{S} .45^{\circ} \mathrm{W}$., a fracture must have occurred between those beds and the gently folded beds exposed in the Norcross-West Valley quarry. In any case the structure west and southwest of the Owls Head is evidently very different from that southeast of Green Peak.

The exposures at the two quarries of the Norcross-West Marble Co. and the core-drill records of the company indicate the following succession, beginning at the top:

Section of marble beds at Norcross-West quarries, South Dorset.

Alternating white and white mottled with light and dark gray marble, with some actinolitic beds, 125 feet, dipping $20^{\circ}$ (the dip of $20^{\circ}$ is assumed here)-that is, crossed by drill at $70^{\circ} \ldots$

Dolomite exposed in Main quarry (10 feet) and also crossed by drill, 20 feet at $30^{\circ}$ (crossed by drill at $\left.60^{\circ}\right) \ldots \ldots \ldots \ldots \ldots$. $10-17$

Gray marbles, 60 feet, dipping $30^{\circ}$ (crossed by drill at $60^{\circ}$ )..... 51

$177-184$

As there is no evidence that the drilling reached the basal dolomite series nor any obtainable data as to the vertical distance between the uppermost bed in these quarries and the base of the schist mass, the figures simply show the thickness explored thus far. The entire 
marble series here should be much thicker. The problem is to ascertain how much marble has been eroded from the surface now quarried and how much intervenes between the lowest bed reached by drilling and the top of the underlying dolomite series.

\section{DORSET MOUNTAIN, OWLS HEAD, AND GREEN PEAK.}

The State report of 1861 in a section ${ }^{1}$ referred to on page 64, shows 86 feet of "blue compact siliceous limestone," presumably gray dolomite, immediately under the schist mass, and states ${ }^{2}$ that near the cave "blue limestone" about 100 feet thick underlies the schist and overlies about 100 feet of coarse marble. Mr. Moffit found on the east side of Green Peak a quartzose dolomite 50 feet below the schist cap and on the north side a 4-foot bed of quartzite 10 feet below the schist. Below the cave he noted 60 to 80 feet of marble. The upper tier of quarries west of the Owls Head is reported by the owners as capped by 50 feet of dolomite. At the Blue Ledge quarry (p. 104) dolomite 25 feet thick overlies 60 feet of mottled marble, which the State geologists ${ }^{2}$ report as being 100 feet thick 10 rods west of the quarry; and Mr. Moffit found the upper beds of the dolomite series along the 1,900-foot level about 100 feet below this quarry. The inference from these data is that on Green Peak there is an upper set of marble beds, separated from the overlying schist in places by at least 50 to 100 feet of dolomite, and a lower set of marble beds, separated from the upper set by an intermediate dolomite in places 100 feet thick, and that these lower marble beds rest upon the basal dolomite.

At the Freedley quarries, on the east side of Dorset Mountain, the following section is exposed, beginning at the top:

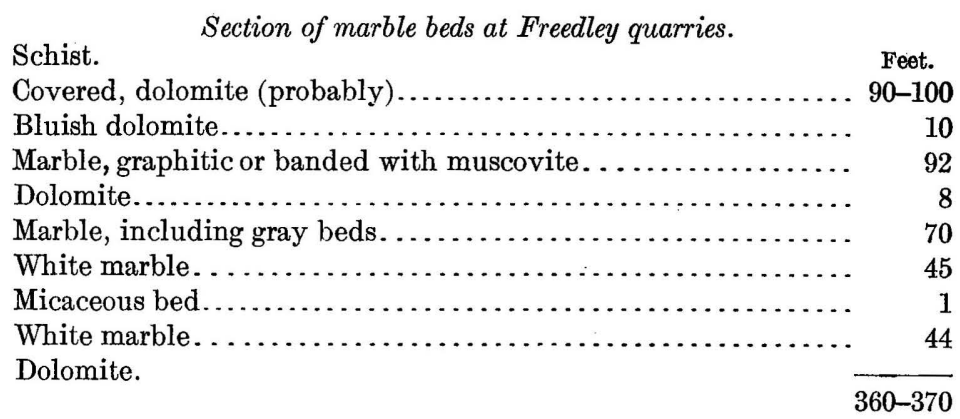

At the White Stone Brook quarry of the Norcross-West Co., on the east side of Dorset Mountain, north-northwest of North Dorset, the series includes the following beds: 
Dolomite........................................ 10

Graphitic marble................................. 10

White marble...................................... 68

Graphitic marble................................ 13

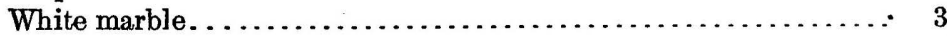

Banded marble....................................... 5

At the Imperial and New York quarries of the Vermont Marble Co., a little farther north in Danby Township, the following series has been made out by quarrying and core drilling:

Section of marble beds at Imperial and New York quarries.

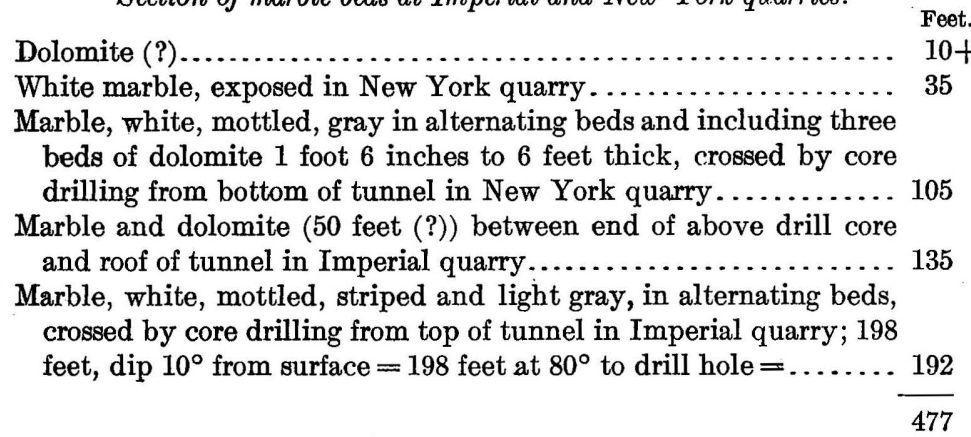

There may be a few feet ( 25 to 50 feet?) between the dolomite series and the lowest point reached by core drill from the tunnel in the Imperial quarry.

By collating these various estimates the following section is obtained for Dorset Mountain and Green Peak:

Section of marble beds on Dorset Mountain and Green Peak.

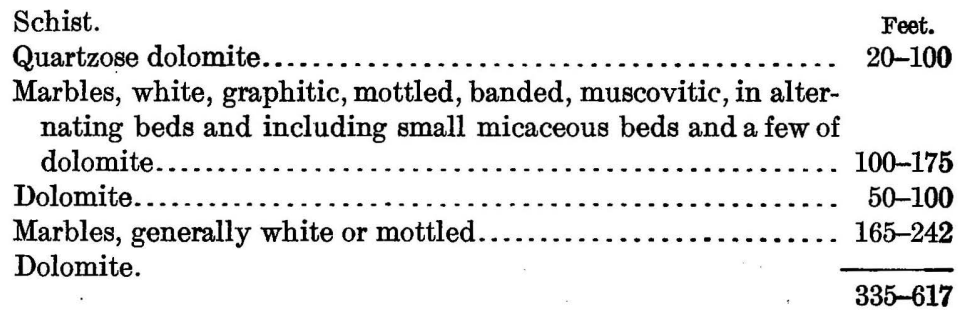

THE ENTIRE MARBLE SECTION.

By abridging and arranging the West Rutland, Proctor, Pittsford, and Dorset Mountain and Green Peak estimates in one table we obtain a view not only of the general character of the marble but also of its local variations, as well as somewhat satisfactory estimates of its maximum and minimum thickness. The beds of South Dorset can not well be tabulated with the others, as their position either 
with reference to the base or top of the marble can not yet be determined.

Marble beds in western Vermont.

\begin{tabular}{|c|c|c|c|c|c|}
\hline & $\begin{array}{c}\text { West } \\
\text { Rutland } \\
\text { anticline, } \\
\text { east side. }\end{array}$ & $\begin{array}{l}\text { West Rutland anti- } \\
\text { cline, west side. }\end{array}$ & Proctor. & Pittsford. & $\begin{array}{l}\text { Dorset } \\
\text { Moun- } \\
\text { tain, } \\
\text { Owls } \\
\text { Head, } \\
\text { and } \\
\text { Green } \\
\text { Peak. }\end{array}$ \\
\hline \multirow{4}{*}{ 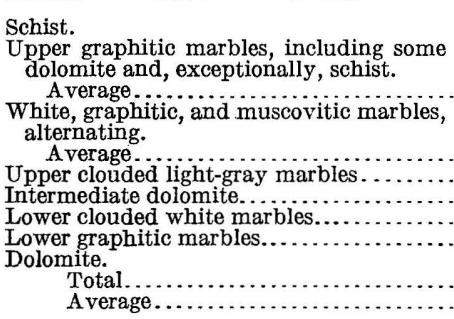 } & \multirow{3}{*}{$\begin{array}{r}\text { Feet. } \\
199-293 \\
\\
(246) \\
180-222 \\
(201) \\
\text { Absent.. } \\
40 \\
\text { Absent.. } \\
296 \\
\end{array}$} & $\begin{array}{l}\text { Feet. } \\
300\end{array}$ & $\begin{array}{l}\text { Feet. } \\
150 \text {. }\end{array}$ & $\begin{array}{l}\text { Feet. } \\
150\end{array}$ & $\begin{array}{l}\text { Feet. } \\
\text { a 20-100 }\end{array}$ \\
\hline & & (Rest not reached:) & Absent.. & Absent. & $100-175$ \\
\hline & & \multirow[t]{2}{*}{$\begin{array}{l}\text { Probably absent. } \\
\text { Not reached....... } \\
\text { Probably absent. } \\
\text { Not reached....... }\end{array}$} & $\begin{array}{r}\text { Absent. } \\
264 \\
172-264 \\
\text { Absent. }\end{array}$ & $\begin{array}{c}230 \\
247 \\
151 \\
\text { Absent.. }\end{array}$ & $\begin{array}{r}50-100 \\
165-242\end{array}$ \\
\hline & $\begin{array}{r}715-851 \\
783\end{array}$ & & $\begin{array}{r}554-678 \\
616\end{array}$ & 778 & $\begin{array}{r}335-617 \\
476\end{array}$ \\
\hline
\end{tabular}

$a$ Mostly if not all dolomite.

Among the most striking features in the table is the disparity in thickness of the intermediate dolomite in the West Rutland and Dorset Mountain sections on the one hand and the Proctor-Pittsford belt on the other. The absence in the Proctor section of both the West Rutland assorted marbles and the Pittsford clouded light-gray marbles, between the intermediate dolomite and the upper graphitic marbles, points to the possibility of a longitudinal fault between the dolomite and the graphitic marbles. The irregularity of the relations north of the anticlinal marble knoll between the Columbian and Proctor quarries has already been pointed out, and the Pine Hill overthrust fault is only 2 miles east. (See map, Pl. I.) Section G (Pl. III) has been drawn tentatively to explain the anomalous character of the Proctor succession. The upper clouded marbles and the white and muscovitic marbles, which normally occur above the intermediate dolomite, are shut out by an overthrust fault which brings that dolomite next to the upper graphitic marbles. Furthermore, the thinning out of the upper graphitic marbles in the Dorset Mountain and Green Peak sections should be noticed. Some of these differences are evidently due to local changes in the character of the sediments in which the marble beds originated.

This table is to be regarded as a summary of such measurements and estimates as are practicable at present and is designed to afford a basis for the more exact determinations which further quarrying, core drilling, and geologic exploration will make possible. It is a tentative section of all the marble beds. 


\section{THE MARBLES AND MARBLE QUARRIES.}

CALCITE AND DOLOMITE MARBLES.

The details as to the quarries and their product will be given in the following order: (1) Name and location of quarry; (2) approximate dimensions; (3) operator's name and address; (4) marble section and thickness of marble beds; (5) principal marbles, scientific and trade names; (6) their colors and mineral composition; (7) texture and textural grade number; (8) analyses and tests, if any; (9) geologic structure; (10) uses of product; (11) location of specimen edifices or monuments.

The more improved machinery in use either at the quarries or the finishing works is referred to on page 156 .

The quarries are taken up by groups in geographic order from south to north. Some idle ones are included on account of their economic or scientific interest.

\section{MANCHESTER.}

DYER QUARRY.

The Dyer quarry is on the south foot of Equinox Mountain, on the D. H. Dyer farm about 250 feet south of the Dyer house (see map, PI. I), a mile north-northwest of the Sunderland station in the town of Manchester. The quarry is not operated. The opening is small and only 30 feet deep.

The marble (specimens D, XVIII, 137, a, c, d, g, rough; D, XXXI, 81 , a, polished) is a breccia with bright brick-red cement and fragments of (1) pinkish to cream-colored and (2) bluish-gray calcite marble, and also of (3) a deep-reddish hematitic calcitic dolomite marble. The breccia is described more fully on page 48 and its general character is shown in Plate VIII, $B, a$. The pinkish marble belongs to grade 4 , the bluish gray to grade 5 , and the reddish to grade 2.

The beds undulate in small folds, striking N. $20^{\circ}-25^{\circ}$ E. The brecciated bed is reported to have been core drilled to a vertical depth of 200 feet. It is bordered on both the east and the west by a light bluish-gray calcite marble like that of some of its fragments. At a point about 3,400 feet S. $25^{\circ} \mathrm{W}$. - that is, along the strikeclose to the Sunderland line, a much jointed gray marble has been prospected, which has dolomite east of and under it. West and south of this prospect, on the cross road, the dips are low to the west. These facts indicate that the breccia will probably be found to be underlain by the dolomitic series at no great depth. There may, however, be a fault along the brecciated bed.

Columns of the breccia 13 feet long have been obtained. The problem is to determine how much of the brecciated bed is free from $49311^{\circ}-$ Bull. 521-12-7 
fragments large enough to deprive it of ornamental quality. The weakness of the marble as a whole is no more of a detriment than that of the imported breccias.

SOUTH DORSET.

A few data were obtained in or as to three idle quarries near South Dorset village. The locations are shown on the map (Pl. I).

BENNINGTON QUARRY.

The Bennington quarry, a little east of the village, is owned by the Bennington Marble Co., St. James Building, Broadway and Twentysixth Street, New York.

\section{KENT \& ROOT QUARRY.}

The Kent \& Root quarry, a little south of the village, is 50 by 60 feet in area and more than 100 feet deep. The marble strikes N. $5^{\circ}-10^{\circ} \mathrm{E}$. and dips $45^{\circ} \mathrm{W}$., but to judge from the blocks on the dumps is much folded.

\section{CONTINENTAL MARBLE CO.'S QUARRY.}

The Continental quarry is a mile west-northwest of the village. The marble is gray and white banded and is overlain by dolomite. The beds, though nearly horizontal, show a minor fold striking clearly N. $55^{\circ}$ E. One set of joints strikes N. $30^{\circ} \mathrm{W}$.; another N. $65^{\circ} \mathrm{W}$.

VALLEY QUARRY (NORCROSS).

The Norcross-West Marble Co.'s Valley quarry is a mile northnorthwest of South Dorset village, and about $2 \frac{1}{2}$ miles S. $79^{\circ} \mathrm{W}$. from the top of Green Peak, the southern outlier of Dorset Mountain, in the southwestern part of Dorset Township. (See map of Equinox quadrangle, U. S. Geol. Survey, and geologic map, Pl. I.) It was opened in 1785 , was worked in 1870 , and reopened in 1902 . It measures about 500 feet in a northeast direction by 100 feet across and averages 70 feet in depth.

Operator, Norcross-West Marble Co., Dorset, Vt.

The marble beds consist, beginning at the top, of 116 feet of marbles, white and white mottled with light and dark gray, underlain by 10 to 17 feet of dolomite, and that in turn by 51 feet of gray marbles. (See p. 93.)

The marbles of this quarry are known as "Dorset A" and "Dorset green bed."

"Dorset A" (specimens D, XXXI, 4 b, rough; e, f, g, polished) is a calcite marble of eream tinted to very light, faintly greenish smoke color, and of coarse irregular texture with grain diameter of 0.07 to 1.25 , exceptionally 2 millimeters, but mostly of 0.25 to 0.75 , averaging by a Rosiwal estimate 0.208 millimeter and thus of grade 5 
(coarse). (See p. 54.) It contains semitranslucent nodules of uncertain composition (carbonate? or silicate) and sparse small grains of quartz. The greenish smoky tint, in places in streaks, appears to be due mainly to the nodules and muscovite, but in places also to pyrite, which measures up to 2 millimeters. The polish when examined with a magnifier is only fair. A thin section of this marble is shown in figure 13.

The following analysis of this marble, recently made at the Worcester Polytechnic Institute for the firm, is published here for reference:

\section{Analysis of calcite marble from South Dorset.}

Calcium carbonate $\left(\mathrm{CaCO}_{3}\right)$

98.43

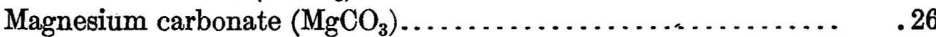

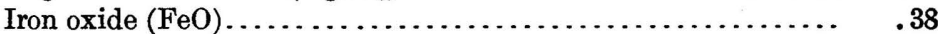

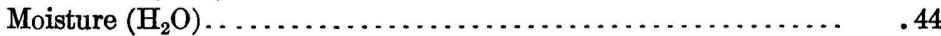

Loss and undetermined.................................. 49

100.00

The results of physical tests of this marble will be found on page 101 .

"Dorset green bed" (specimens D, XXXI, 4, a, rough; c, d, polished) is an actinolite-calcite marble of faintly greenish to pale cream color with very dark to light greenish-gray streaks, really beds, not over 0.1 inch thick (where single and straight), acutely plicated at intervals. Its texture is coarse but more regular than that of "Dorset A." As its grain diameter is 0.12 to 1 , mostly 0.25 to 0.62

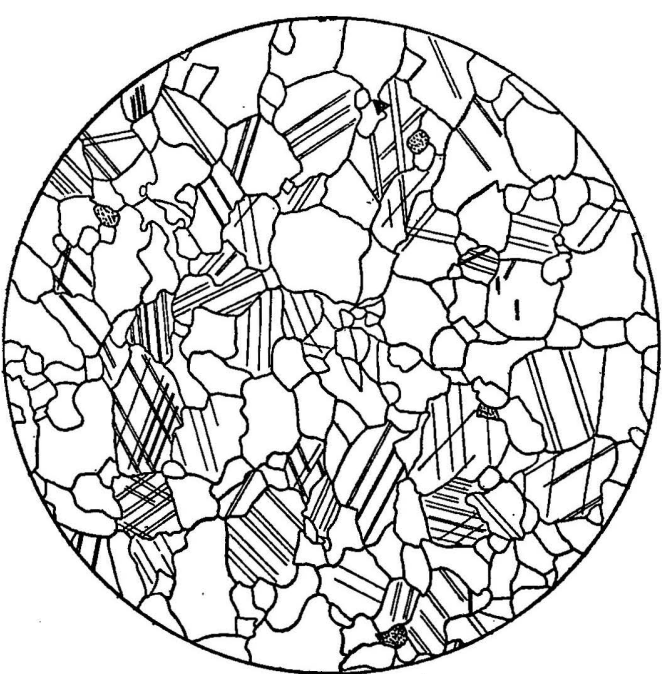

FIGURE 13.-Thin section of "white" calcite marble, "Dorset A," from the Norcross-Wèst Valley quarry near South Dorset. Texture, grade 5. Dotted particles are quartz. Enlarged 20 diameters.

millimeter, it is also of grade 5 . The little gray-greenish beds consist of fibrous actinolite with a little quartz and irregular semitranslucent nodules of uncertain character and bluish-green tourmaline. Pyrite is plentiful up to 0.5 millimeter in diameter. Some limonite stain appears, presumably from the oxidation of the pyrite. The polish over the actinolite streaks is naturally poor. 
The pilasters of the "green bed" shown in Plate VII, which were cut parallel to the strike of the bed, seem to indicate some brecciation in that direction.

The structure at this quarry seems to be that of a very gentle anticline with a $\mathrm{N} .70^{\circ} \mathrm{E}$. strike, but at the northeast end of the quarry the beds rise in minor folds with an average dip of $30^{\circ}-40^{\circ} \mathrm{NNW}$. and a pitch of $10^{\circ} \mathrm{N} .30^{\circ} \mathrm{E}$. and the dolomite bed which underlies the marble of the center of the quarry reaches the surface with a thickness of 10 to 12 feet. This indicates a syncline between the northeast wall and the anticline of the quarry. Two vertical joints occur along the east wall with strike of N. $20^{\circ} \mathrm{E}$. The strike of the marble $\left(\mathrm{N} .70^{\circ} \mathrm{E}\right.$.) seems to be related to the N. $55^{\circ} \mathrm{E}$. strike at the Continental quarry, a mile nearly southwest, and at the quarries near the Owls Head, a mile northeast. The dolomite is crossed by cleavage planes filled with quartz dipping about $20^{\circ} \mathrm{E}$. A thin section of this rock is described on page 30 .

The product of this quarry will be given in connection with the Plateau quarry for the reason that in many structures the marbles have been combined.

PLATEAU QUARRY.

The Plateau quarry of the Norcross-West Marble Co., situated 480 feet northeast of the Valley quarry, is of irregular form and averages about 90 by 80 feet and 15 to 40 feet deep. The stripping consists of 10 to 16 feet of gravel and fine sand. A view of part of the quarry is shown in Plate X, $A$.

The relation of the marble beds in this quarry to those in the Valley quarry is very uncertain, as neither the outcrops nor the core-drill records make it clear. These records indicate at least 80 to 100 feet of marble beds at this quarry. The marble, known as "Dorset B," is of a darker shade than "Dorset A.".

"Dorset B" (specimens D, XXXI, 4B, a, rough; 4B, b and c, polished) is a calcite marble of light cream color, clouded with lightgray to smoke tint, and of coarse texture, somewhat less irregular than that of "Dorset A," with a grain diameter of 0.07 to 1.12, mostly 0.25 to 0.62 millimeter, of grade 5 . It contains some grains of quartz, groups of grains of granitic or vein quartz, rare grains of potash feldspar (microcline), stringers of fibrous muscovite, and plates of white mica, also irregular minute semitranslucent nodules like those of "Dorset A" and a little pyrite in fine particles and crystals and limonite stain. The gray shade appears to be due to the muscovite, the pyrite, and the nodules.

The structure at the northeast end of this quarry shows a strike of $\mathrm{N} .70^{\circ} \mathrm{W}$. At the southeast end the marble is intensely and acutely plicated; the little folds are 6 inches wide and 5 feet long. 
It is not clear whether these are horizontal folds in a vertical stratum or minor folds along a very gently dipping one.

Tests of compressive and transverse strength of the marbles of the Valley and Plateau quarries were made for the company at the United States arsenal at Watertown, Mass., on March 5, 1903, with the following results:

Results of physical tests of marble from South Dorset.

Compression tests.

[6-inch cubes.]

\begin{tabular}{|c|c|c|}
\hline Marble. & $\begin{array}{l}\text { Strength per } \\
\text { square inch } \\
\text { tested on bed. }\end{array}$ & $\begin{array}{l}\text { Strength per } \\
\text { square inch, } \\
\text { tested on edge. }\end{array}$ \\
\hline $\begin{array}{l}\text { Dorset A } \\
\text { Dorset } \mathrm{B}, \ldots \ldots \ldots \\
\text { Dorset green bed } \ldots \ldots \ldots \ldots\end{array}$ & $\begin{array}{r}\text { Pounds. } \\
11,270 \\
11,170 \\
11,460\end{array}$ & $\begin{array}{l}\text { Pounds. } \\
\qquad \begin{array}{r}8,400 \\
9,460 \\
9,440\end{array}\end{array}$ \\
\hline Average.. & 11,300 & 9,100 \\
\hline
\end{tabular}

Transverse tests.

[Samples 26 inches long and 3 inches square; supports 24 inches apart; load applied at middle.]

\begin{tabular}{|c|c|c|c|c|c|}
\hline & \multirow{3}{*}{ Marble. } & \multicolumn{4}{|c|}{ Ultimate transverse strength. } \\
\hline & & \multicolumn{2}{|c|}{ Tested on bed. } & \multicolumn{2}{|c|}{ Tested on edge. } \\
\hline & & Pounds. & $\begin{array}{l}\text { Modulus } \\
\text { of } \\
\text { rupture. }\end{array}$ & Pounds. & $\begin{array}{l}\text { Modulus } \\
\text { of } \\
\text { rupture. }\end{array}$ \\
\hline \multicolumn{2}{|c|}{$\begin{array}{l}\text { Dorset A... } \\
\text { Dorset B... } \\
\text { Dorset green }\end{array}$} & $\begin{array}{l}657 \\
605 \\
787 \\
776 \\
594 \\
625 \\
\end{array}$ & $\begin{array}{r}860 \\
780 \\
1,010 \\
1,010 \\
780 \\
620 \\
\end{array}$ & $\begin{array}{l}655 \\
564 \\
774 \\
682 \\
650 \\
781\end{array}$ & $\begin{array}{r}840 \\
720 \\
1,010 \\
890 \\
850 \\
1,010 \\
\end{array}$ \\
\hline \multicolumn{2}{|c|}{ Average... } & 674 & 843 & 684 & $\overline{886}$ \\
\hline
\end{tabular}

The marble of the Plateau quarry, "Dorset B," and the "Dorset $A$ " from the Valley quarry are used for construction and the "green bed" for internal decoration.

Specimens: A triangular block of white marble taken from a building close to the main quarry, inscribed "A. D. 1831," in which the letters and figures have preserved their sharp edges and which in all probability came from the adjacent quarry opened 46 years earlier, is regarded as the best evidence of the weathering quality of "Dorset A" marble.

The more important edifices made from these marbles are the New York Public Library, Forty-second Street and Fifth Avenue (except the approaches); the entire group of buildings of the Harvard Medical School; the John Hay Memorial Library, Brown University, 
Providence, R. I.; the Memorial Continental Hall, Washington (except northwest corner), including 13 monolithic 27-foot columns, (Pl. XI); the Royal Bank of Canada, Toronto; the Art Association Building, Montreal, with four 32-foot monolithic columns (see Pl. $\mathrm{X}, A)$; the portico and columns of the residence of Mr. W. T. Sessions, Bristol, Conn.; and the Congregational Church at Dorset, Vt.; and of "Dorset B" the exterior of the residence of Henry Phipps, Fifth Avenue and Eighty-seventh Street, New York.

The "green bed" supplied the panels and wainscoting of the National Commercial Bank, Albany, N. Y.; the interior of the American Trust \& Savings Bank, Chicago; and the interior marble (except flooring) of the Hampden County courthouse at Springfield, Mass., including the columns in the rotunda and the pilasters shown in Plate VII.

\section{OWLS HEAD QUARRIES.}

There are two quarries in an upper and two in a lower tier, situated about half a mile west of the Owls Head, about $1 \frac{1}{2}$ miles north of South Dorset village, on the 1,400 and 1,670 foot levels-that is, 500 and 770 feet above the village. The Owls Head is the western summit of the schist outlier of Dorset Mountain, of which Green Peak is the eastern and higher point. (See map, Pl. I.) One of these quarries is reported to have been reopened in 1903; the others have been idle many years. The property is said to be controlled by the Dorset Mountain Marble Co., of East Dorset, Vt.

The marble of the upper two quarries is reported as measuring altogether 150 feet, covered by 50 feet of dolomite, and that of the lower ones as consisting of 80 feet of mixed white and gray marbles. That these apparent thicknesses are not the actual ones is evident from the facts given in the discussion of structure (p. 93). Wherever the beds are not doubled over on themselves the thickness must be much less.

A specimen of white marble from the northwestern or tunnel quarry of the upper tier is a coarse white calcite marble with grain diameter of 0.05 to 1.37 , mostly 0.25 to 0.75 millimeter, and belongs to grade 5. A specimen of clouded white marble from the lower tier has a grain diameter of 0.07 to 1.12 , mostly 0.25 to 0.62 millimeter; and is also of grade 5 . It contains plentiful quartz grains in places, with stringers of muscovite and a little pyrite.

The structure at these quarries is of very intricate character, ${ }^{1}$ as shown by figure 14 and Plate XVI, $B$ (p. 132). In the northwestern upper quarry, where an apparent thickness of 100 feet is exposed with an apparent dip of $5^{\circ}-10^{\circ} \mathrm{N} .55^{\circ} \mathrm{E}$., the marble consists of minor folds drawn out in an almost horizontal direction by flowage, so that a fold

1 Hitchcock and Hager noticed some structural irregularity here (Geology of Vermont, vol. 2, 1861, p. 756, fig. 325). 


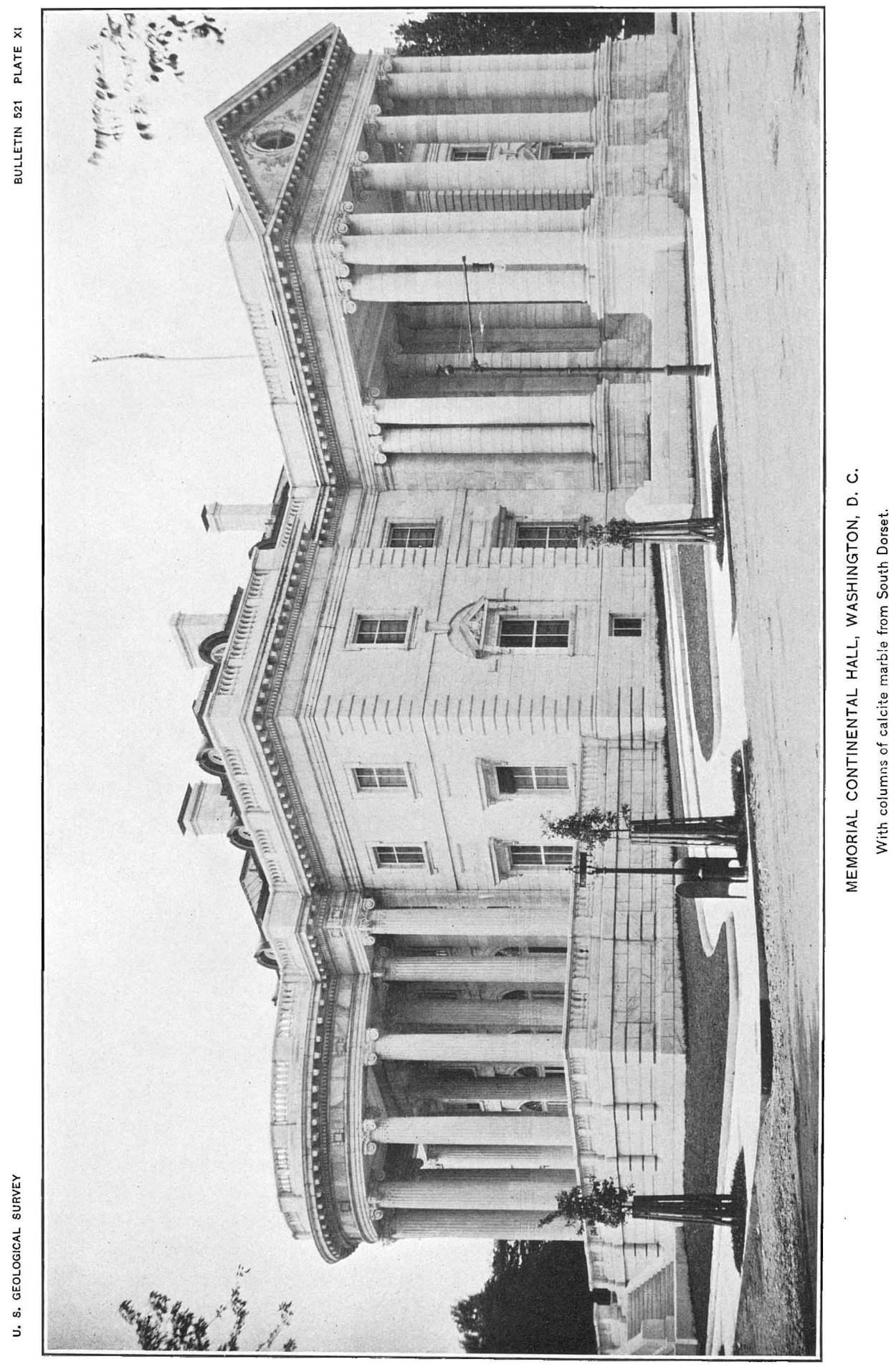



measuring only a foot in thickness at its thickest part, where doubled, has its apex 60 feet away. One fold 25 feet long by 5 feet in width, doubled, is probably altogether 50 feet long and 6 feet across at its widest part. (See fig. 14,a.) In the southeasterly quarry of the upper tier marble and dolomite are interbedded, as shown in figures 5 and $14, b$. In the lower tier of quarries similar compressed and elongated folds occur (fig. 14, $c$ and $d$ ). ${ }^{1}$ The axes of these folds strike N.

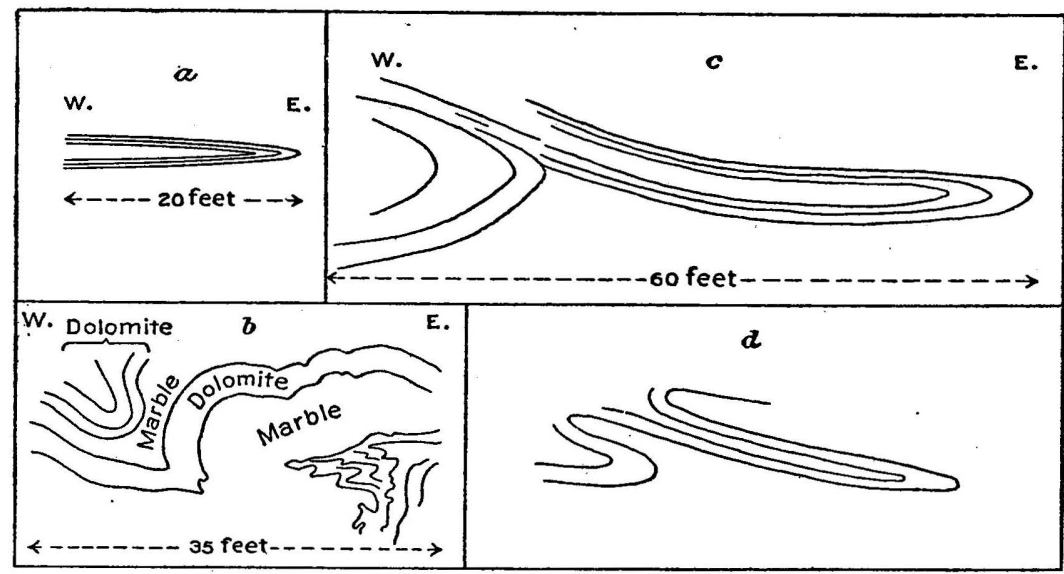

Figure 14.-Marble folds in quarries near Owls Head. $a$, Elongated fold; $b$, untwinned dolomite and calcite marble interbedded; $c$, present structure; $d$, probable structure of $c$ at an earlier stage.

$15^{\circ}-60^{\circ} \mathrm{E}$. The first inference from such structure is that no reliable measures of the thickness of the marble can be taken in this part of the mountain. A vertical joint in the tunnel quarry strikes N. $50^{\circ}-55^{\circ} \mathrm{E}$., and at the eastern one the joints strike N. $25^{\circ} \mathrm{E}$. and $\operatorname{dip} 35^{\circ} \mathrm{S} .65^{\circ} \mathrm{E}$.

\section{GREEN PEAK QUARRIES.}

Green Peak (Hitchcock's Mount Eolus), altitude 3,185 feet, although popularly confounded with Dorset Mountain, is properly an outlier of that mountain and of its schist mass. (See map, Pl. I; also maps of Pawlet and Equinox quadrangles, U. S. Geol. Survey.) Marble was early quarried on its southeast side at the 2,100-foot level, or about 1,300 feet above the Vermont Valley at East Dorset.

\section{DEAF JOE QUARRY.}

There are two small and disused marble openings about threefourths of a mile and 1 mile roughly southwest of Green Peak, one of which is known as the Deaf Joe quarry. At the lower one, on the 1,450 -foot level, a white marble strikes N. $60^{\circ}$ E. and dips $25^{\circ}$ N. $30^{\circ}$ W. At the upper one, on the 1,800 to 1,870 foot level, mottled marble about 20 feet thick is exposed with a very low westerly dip.

\footnotetext{
1 This interbedding of dolomite and marble has been referred to on p. 31 and also in Bull. U. S. Geol. Survey No. 195, 1902, pp. 13-15.
} 
BLUE LEDGE QUARRY.

The Blue Ledge quarry, opened in 1825 or earlier, was known as the Holley, Fields \& Kent, or Kent quarry, later as the Blue quarry. ${ }^{1}$ It is about on the 2,000 -foot level, half a mile S. $60^{\circ} \mathrm{E}$. from Green Peak and a mile S. $80^{\circ} \mathrm{W}$. from East Dorset village, in the township of Dorset. (See map, Pl. I.) The view from the top of the dumps of this quarry, looking down the Vermont Valley, is one of the finest in the State. The quarry measures about 350 feet north to south by 100 feet across and has walls 60 to 85 feet high. It has recently been reopened. Operator, Norcross-West Marble Co., Dorset, Vt.

The marble beds exposed here consist of 60 feet of mottled marble overlain by 25 feet of bluish dolomite, but the 1861 Vermont report ${ }^{2}$ states that this dolomite bed measures about 100 feet 10 rods west of the quarry. As there is marble above the dolomite this may be an intermediate dolomite.

The marble (specimens D, XXXI, 9, a, rough; c, d, e, polished), "Dorset Mountain," is a calcite marble of faintly bluish white tint, irregularly mottled with very light gray and of irregular texture, consisting in the darker mottling of untwinned dolomite grains with a diameter of 0.02 to 0.12 millimeter and thus of grade 1 , but in the general white mass of twinned denticular calcite grains with a diameter of 0.25 to 0.75 millimeter and thus of grade 5. It contains sparse quartz grains up to 0.32 millimeter, somewhat plentiful, pyrite crystals and particles, rare muscovite, and very minute undetermined black particles. The stone takes a fair polish, but the dolomitic mottling, being harder than the calcite ground, projects in minute relief on the polished face.

The marble and dolomite beds dip $10^{\circ} \mathrm{SSE}$. and $5^{\circ} \mathrm{NNW}$., forming a very gentle anticline with an axis pitching gently south. The chief joints strike N. $10^{\circ} \mathrm{E}$. and N. $80^{\circ} \mathrm{W}$. and are steep or vertical. The marble beds or some of them are separated by beds an inch thick of white pyritiferous, quartzose, micaceous dolomitic calcite marble which weathers light brown. In thin section this rock consists of calcite grains up to 0.5 millimeter in diameter, with finely disseminated limonite and crystals of pyrite passing into limonite, many quartz grains, fibrous muscovite, large scales of chlorite and muscovite, and also nodules of dolomite up to 0.3 inch. This marble has not yet been used to any great extent.

\section{FOLSOM QUARRY.}

Between one-fourth and one-third of a mile south-southwest of the Blue Ledge quarry is the long disused Folsom quarry (see map, Pl. I), the floor of which is but a few feet higher than that of the Blue

1 Hitchcock, Edward, and Hager, A. D., Geology of Vermont, vol. 2, 1861, pp. 757-759.

2 Idem, p. 759. 
Ledge. The quarry is about 100 feet square and has walls 50 feet high. Its floor is underlain by 10 feet of dolomite, upon which lies more or less mottled calcite marble, about 50 feet thick.

The beds strike N. $60^{\circ} \mathrm{W}$., dip $10^{\circ} \mathrm{N}$. $30^{\circ} \mathrm{E}$., and are crossed by vertical joints striking $\mathrm{N} .80^{\circ} \mathrm{W}$. and $\mathrm{N} .15^{\circ} \mathrm{E}$., which form three walls of the quarry. At the west wall is a vertical dike from 1 foot to 2 feet 6 inches wide, becoming 8 feet a little beyond, with a N. $35^{\circ}-40^{\circ} \mathrm{E}$. course. The dike above the quarry floor has been quarried away or is covered with débris. The marble on either side of it is incrusted with limonite and stained red with hematite. On the quarry side the marble for 2 to 3 feet from the dike is much shattered and veined with calcite in crystals.

\section{EAST DORSET ITALIAN QUARRY.}

The East Dorset Italian quarry, also idle in 1910, is between the Folsom and Blue Ledge quarries about 300 feet south of the latter. Owner, Dorset Mountain Marble Co., East Dorset, Vt.

In 1900 marble about 35 feet thick was in sight and drillings at the bottom of quarry showed 17 feet more-beginning above, three 3 -foot beds, one 2-foot, and one 6-foot.

Specimens M, IV, 192, a to d, from the west side, floor and 10 and 20 feet up, and from the south side, show a coarse white calcite marble of grade 5 , in places with grayish bands or with limonitic bands from oxidized pyrite. A polished specimen (D, XXXI, 79, a) is of light bluish-gray color, with little plicated dark-gray graphitic beds.

The beds are horizontal; vertical joints strike N. $80^{\circ} \mathrm{E}$. and N. $10^{\circ} \mathrm{W}$., and one dipping $70^{\circ} \mathrm{N} .55^{\circ} \mathrm{W}$. strikes N. $35^{\circ} \mathrm{E}$.

\section{QUARRIES ON DORSET MOUNTAIN.}

FREEDLEY QUARRIES.

The Freedley quarries include four openings: (1) The Tunnel quarry, opened about 1790, is about a mile west of Freedleyville, 1,160 feet above it, on the 2,040-foot level. It is on the east side of the southern and eastern spur of Dorset Mountain, in the town of Dorset. (See map, Pl. I, and map of Pawlet quadrangle, U. S. Geol. Survey.) This quarry has an east-west tunnel 160 feet long. (2) The Upper quarry, north of the Tunnel quarry, is also of very early date. (3) The Open quarry, begun in 1909, is about 500 feet northeast of the Tunnel quarry and about 100 feet lower. (4) The Scotchman's quarry, begun in 1910, is over half a mile north of the Open quarry.

Operator, Manchester Marble Co., East Dorset, Vt., also Graham Avenue and East River, Astoria, Long Island City, N. Y. 
The marble beds, as reported by the superintendent, include the following:

Section of marble beds at Tunnel and Open quarries, Freedleyville.

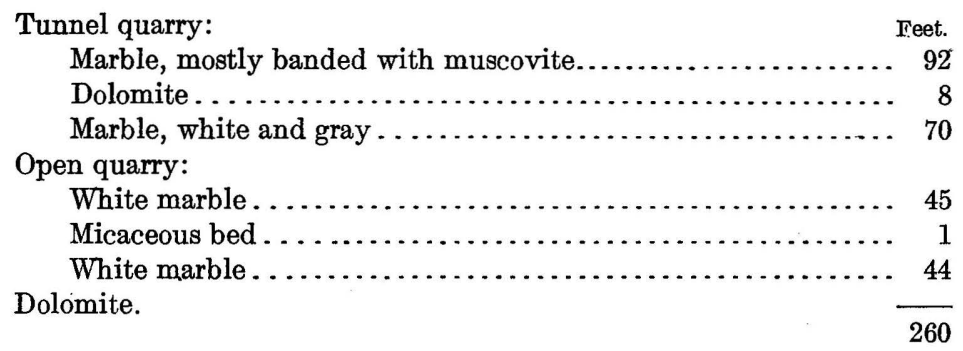

Mr. Moffit in 1900 noted the following section at the Upper quarry:

Section of marble beds at Upper quarry, Freedleyville.

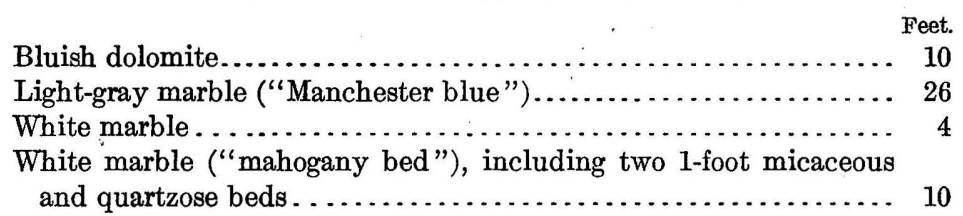

At the Tunnel quarry Mr. Moffit observed a dolomite overlying 15 feet of coarse white marble. He reported 110 feet of marble in all, three-fourths of which was good. He also found the schist boundary a little farther north, 100 feet above the bluish dolomite.

The marble of the Open quarry (specimen D, XXXI, 8, a, rough) is a translucent, faintly cream tinted coarse white calcite marble with a grain diameter of 0.12 to 1 , mostly 0.25 to 0.5 millimeter, and thus of grade 5. The "Manchester blue" (specimen M, V, 6, j) of the Upper quarry is a very light bluish-gray. coarse calcite marble with a grain diameter of 0.05 to 1.37 , mostly 0.25 to 0.75 millimeter, also of grade 5. It contains rare minute quartz grains, a few stringers of fibrous muscovite and plates of muscovite, and cubes and spherules of pyrite, to the oxidation of which the cream tint is probably due. The "mahogany" (specimen M, V, 6, h) of the same quarry is a milkwhite calcite marble of very irregular texture, with grain diameter ranging from 0.05 to 1.5 , mostly 0.125 to 0.75 millimeter, and thus also of grade 5. It contains a few small quartz and feldspar (plagioclase) grains

A hand specimen (M, V, 6, m) from the 15-foot bed of the Tunnel quarry resembles the white of the Open quarry. A polished specimen of the "white" (D, XXXI, 8, c) from one of the beds now worked is of extremely light bluish-gray color and of irregular texture, with grain diameter up to 2 millimeters. A polished specimen of the "cloud" (D, XXXI, 8, d) is of very light bluish-gray color with a medium gray dolomitic bed up to 0.2 inch wide and irregular gray 
spots near it. The texture is uneven and irregular, with grain diameter in the calcitic part up to 1.5 millimeters. Both specimens take a good polish, but the dolomitic bands project in minute relief. A specimen (D, XXXI, 8, b) of one of the micaceous beds consists of light bluish-gray and white calcite marble with grayish micaceous and pyritiferous lenses or beds, some not over 0.02 inch and others 0.1 inch thick. In thin section these lenses consist of fibrous muscovite and quartz with lenses and crystals of pyrite. The marble parts also contain a few quartz grains, muscovite scales, and a little pyrite.

The older openings were made between two trap dikes about 200 feet apart. The eastern dike is about 6 feet wide, strikes N. $25^{\circ} \mathrm{E}$. and dips $80^{\circ} \mathrm{W}$. The marble beds are horizontal. Vertical joints strike N. $10^{\circ} \mathrm{E}$. and N. $65^{\circ} \mathrm{W}$.; others strike N. $30^{\circ} \mathrm{E}$. and $\operatorname{dip} 65^{\circ}$ E., and still others strike N. $20^{\circ} \mathrm{E}$. and $\operatorname{dip} 60^{\circ} \mathrm{W}$., which is not far from the course of the eastern dike.

The marble is used for interiors and exteriors of buildings. Specimens: Soldiers and sailors' monument, Riverside Drive; Drexel Building, southeast corner of Wall and Broad streets, New York.

\section{WHITE STONE BROOK QUARRY.}

The recently opened White Stone Brook quarry is on the east flank of the northern part of Dorset Mountain, about 200 feet above the most conspicuous bench or shoulder, the second one from below, and about 1,180 feet above the railroad in the valley. It lies about N. $80^{\circ} \mathrm{W}$. of a steep ravine in the Green Mountain range, shown in Plate III, section A. The quarry is a little south of the DanbyDorset town line, which is also the Rutland-Bennington county line, in the township of Dorset. It has a working face 78 feet high. Operator, Norcross-West Marble Co., Dorset, Vt.

The marble beds exposed here and prospected by drilling are, in natural order:

Section of marble beds at White Stone Brook quarry.

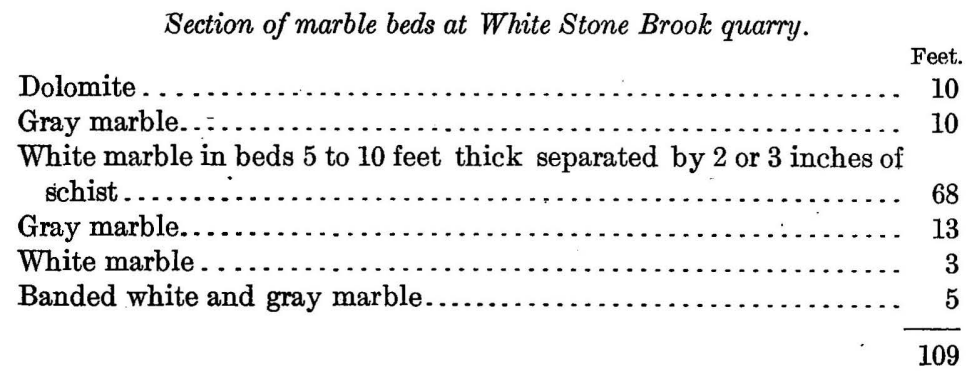

The marble beds mostly alternate with beds of slickensided pyritiferous quartzose mica schist a few inches thick, the pyrite crystals elongated in the direction of slickensiding. This schist consists of calcite and vein quartz in lenses or beds alternating with fibrous muscovite, containing chlorite and lenses up to 0.25 millimeter thick, 
probably of some carbonate. In parts calcite, quartz, and sericite also occur mingled.

The marble (specimens D, XXXI, 5, a, rough; c, d, e, polished), "White Stone Brook," is a coarse calcite marble of faintly cream-

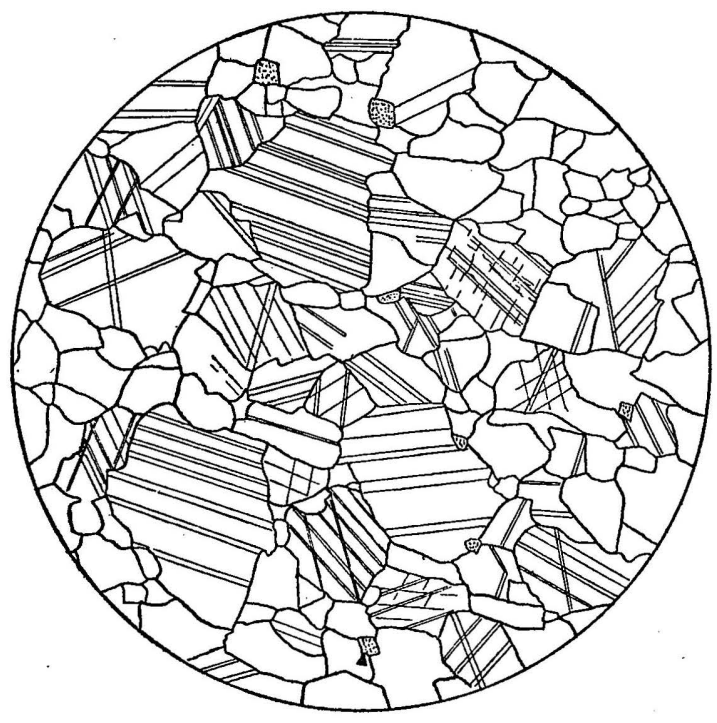

FIGURE 15.-Thin section of white calcite marble from White Stone Brook quarry, Dorset Mountain. Dotted particles are quartz; black are pyrite. Enlarged 20 diameters. tinted, somewhat translucent color, with fine yellowgreenish-gray streaks and spots hardly apparent in the rough but showing on a polished or rubbed face, and of very irregular texture, with grain diameter of 0.05 to 1.5 , exceptionally 2.5 millimeters, mostly 0.25 to 0.75 millimeter, and of grade 5. An estimate by the Rosiwal method shows the average grain diameter to be 0.239 millimeter. The marble contains also sparse quartz in grains up to 0.3 millimeter in diameter, pyrite next in abundance, a few muscovite scales, rare grains of feldspar (plagioclase), and minute black particles of uncertain nature. The streaks and spots are caused by collections of these accessory minerals. This marble takes a good polish. A thin section of it is shown in figure 15.

The beds dip in gentle undulations $5^{\circ}$ to $10^{\circ} \mathrm{E}$. In the front (east) part of the quarry is a trap dike, not studied microscopically, 3 to 4 feet thick, with a N. $35^{\circ} \mathrm{E}$. course and a dip of $70^{\circ} \mathrm{N} .55^{\circ} \mathrm{W}$. Joints in the marble parallel to the dike and also fractures east of it, striking $\mathrm{N} .55^{\circ} \mathrm{E}$. and dipping $50^{\circ} \mathrm{SE}$., deprive the marble there of value. The outer surface of the marble beds is also crossed by cleavage planes ("reeds"), striking N. $27^{\circ}$ E., dipping $30^{\circ}$ S. $63^{\circ}$ E., and spaced 2 inches to 0.25 inch apart, which have the same effect.

The product is used for construction.

\section{IMPERIAI QUARRY.}

The Imperial quarry is on the east flank of the northern part of Dorset Mountain, in the town of Danby, in Rutland County, a little north of the Danby-Dorset town line, about 700 feet above 
Danby station, or 1,690 feet above sea level, N. $60^{\circ} \mathrm{W}$. of a conspicuous steep ravine in the Green Mountain range. For its general position see Plate I and map of Pawlet quadrangle, United States Geological Survey, and for the general form of benches and knolls of this side of Dorset Mountain, see Plate III, section A. The quarry, opened since 1900 , consists of a tunnel running 160 feet in a N. $70^{\circ}$ $\mathrm{W}$. direction by 45 feet in a N. $10^{\circ} \mathrm{E}$. direction and 50 feet high, with an offset 25 feet square on the floor level. Operator, Vermont Marble Co., Proctor, Vt.

The marble beds here, as exposed in quarrying and core drilling, consist, measuring from the roof of the tunnel downward and making deduction for inclination of the bed, of about 192 feet of light marbles, creamy white, bluish white, mottled, banded, clouded, or gray in various alternations. Beds of marble 4 to 8 feet thick are separated by very thin beds of mica schist. In a now disused open cut above and west of the tunnel from 30 to 40 feet of light marbles are exposed. Here the schist beds are as much as a foot thick, are rather quartzose, and contain calcite crystals an inch across.

The marble (specimen D, XXXI, 6, c, rough; a, cube; b, polished), "Danby," is a coarse calcite marble of faintly cream-tinted, somewhat translucent color with yellow-greenish-gray irregular streaks or mottlings which are much more conspicuous on the polished face than on the rough, of irregular texture, with a grain diameter of 0.07 to 1 , mostly 0.17 to 0.62 millimeter, and thus of grade 5 . It contains sparse quartz grains and some pyrite (rarely as large as 2 millimeters), some muscovite scales, and minute black specks. The greenish-gray streaks and clouds are due to muscovite and pyrite in very minute particles. The polish is good but is affected slightly by the composition of the little beds. The general texture of the marble is similar to that shown in figure 15.

The beds strike N. $40^{\circ} \mathrm{W}$. and dip $10^{\circ} \mathrm{S} .50^{\circ} \mathrm{W}$. In the open cut above the tunnel the marble is in open folds 50 feet in diameter, with a N. $40^{\circ}$ E. strike. At the mouth of the tunnel cleavage planes ("reeds") strike N. $15^{\circ} \mathrm{E}$. and dip $35^{\circ} \mathrm{E}$.; these decrease in abundance within the tunnel. Joints in upper beds of the open cut strike N. $33^{\circ}$ E. and also less commonly N. $57^{\circ} \mathrm{W}$., both sets being of steep dip. There is a 3-foot bed in the open cut full of "reeds" dipping $40^{\circ} \mathrm{E}$. These are reported by the foreman as being less abundant in the micaceous beds.

\section{NEW YORK QUARRY.}

The New York quarry is about one-fourth mile west of the Imperial quarry and about 240 feet above it (see map, PI. I) and of more recent date. It has a tunnel 150 feet wide and 35 feet high running 215 feet southwest. The northeastern part of this tunnel has been deepened to 100 feet over a space 55 feet square; 125 feet north of 
this tunnel is another 40 feet wide and 20 feet high, running 80 feet southwest. This northern tunnel is shown in Plate $\mathrm{X}, B$.

The marble beds here include, in natural order:

Section of marble beds at New York quarry.

Dolomite (?) above tunnel. . . . . . . . . . . . . $10 \ldots \ldots \ldots \ldots \ldots . \quad 10$

White marble exposed in south tunnel..................... 35

Bluish, cream, white mottled; and light-gray calcite marbles in alternating beds, including three beds of dolomite ( 1 foot 8 inches, 1 foot 6 inches, and 6 feet) all crossed by drilling............ 105

150

The marbles are not essentially different from those of the Imperial quarry, described above.

The beds are inclined $10^{\circ}$ to $15^{\circ} \mathrm{S} .15^{\circ} \mathrm{W}$. This probably represents a very low, nearly west dip combined with a southerly pitch of the fold. At the north side of the southern tunnel is a dike of augite camptonite (see p. 72) 5 feet 6 inches wide with a N. $25^{\circ} \mathrm{E}$. course and a dip of $65^{\circ} \mathrm{N} .65^{\circ} \mathrm{W}$. For a space of 80 feet northwest of the dike-that is, above it-the marble is crossed by many joints parallel to the dike, and these are crossed by another set, as shown in Plate $\mathrm{X}, B$. Although the marble above the dike has been thus rendered valueless, that on the other side, under the dike in the southern tunnel, is sound. Fifty feet northwest of the northern tunnel another dike of augite camptonite only 2 to 4 inches thick cuts the marble with a N. $30^{\circ}$ E. course and a dip of $70^{\circ} \mathrm{N} .60^{\circ} \mathrm{W}$., and the marble for a space of 30 feet above and northwest of this dike also is much jointed.

The marble of both the Imperial and New York quarries is used largely for construction, but some is suitable for monuments. The Chelsea Bank, Chelsea, Mass., and the Wheeler residence, Chicago, were made almost entirely of this marble.

\section{CLARENDON QUARRIES.}

CLARENDON VALLEY QUARRY.

The Clarendon Valley quarry is on the east side of the intermediate range, on the J. D. Pratt farm, about $1 \frac{1}{4}$ miles south-southeast of Clarendon village church and 2 miles southwest of East Clarendon, in the Otter Creek Valley, half a mile east of the creek, in Clarendon Township. (See map of Rutland quadrangle, U. S. Geol. Survey.) The quarry, opened in $1909-10$, is 50 by 35 feet and 9 feet deep. Operator, Clarendon Valley Marble Co., 29 Broadway, New York, or Clarendon, Rutland County, Vt.

The marble beds exposed here consist of at least 70 feet of calcite marble.

The marble (specimens D, XXXI, 28, a, rough; b, c, polished), "Clarendon Valley gray," is a calcite marble of very light bluish-gray 
color, with fine, closely and acutely plicated dark-gray dolomite beds. The calcite marble of the ground is of irregular texture, with grain diameter of 0.5 to 2 , mostly 0.12 to 0.5 millimeter, and thus of grade 5 (coarse). The little dolomite beds consists of irregular and rhombic untwinned dolomite with a grain diameter of 0.025 to 0.1 , mostly 0.05 to 0.07 millimeter, and thus of grade 1. Graphite abounds in the dolomite beds, but occurs also sparsely throughout the calcite marble, as does also quartz. There are rare grains of feldspar (orthoclase, plagioclase, and microcline), muscovite flakes, sericite stringers, and small particles of pyrite in the calcite, but pyrite abounds in the dolomite bands. The polish is good except on the dark bands. Some of the marble, "Clarendon white," is a trifle lighter and has fewer gray streaks.

The beds strike N. $55^{\circ}-60^{\circ}$ E. and $\operatorname{dip} 25^{\circ}$ N. $33^{\circ}$ W. They are crossed by cleavage dipping $25^{\circ} \mathrm{E}$. There are large exposures of either the basal dolomite or the intermediate dolomite with a westerly dip between the quarry and Clarendon village, on the east side of the road. The marble of the quarry evidently belongs between the basal and intermediate dolomite, probably near the former.

\section{CLARENDON QUARRY.}

The Clarendon quarry is east of the foot of the Taconic Range, 3 miles south-southeast of West Rutland, in the township of Clarendon. (See Pl. I and map of Castleton quadrangle, U. S. Geol. Survey.) The quarry, an old one, abandoned before 1900 but reopened in 1909, is about 100 feet north to south by 51 feet across, with an average depth of 30 feet. Its length is being extended 40 feet. Operator, Clarendon Marble Co., West Rutland, Vt.

The marble beds exposed and prospected are, in natural order, as follows:

\section{Section of marble beds at Clarendon quarry.}

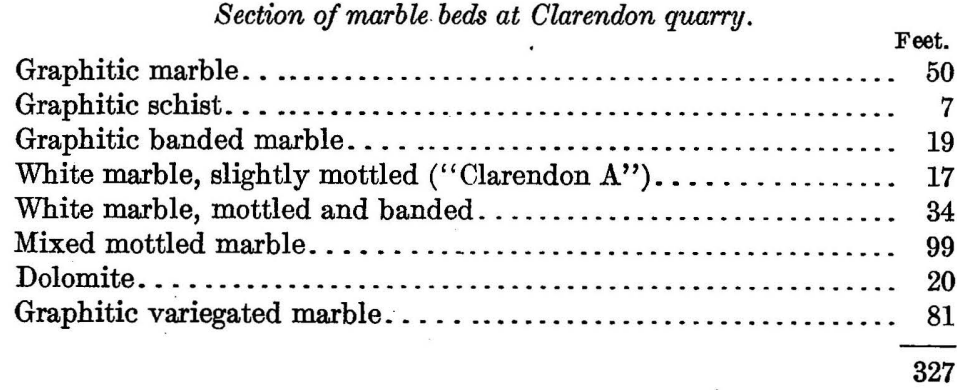

The schist boundary must be very near the top of the series.

"Clarendon A" (specimen D, XXXI, 27, a, rough; f, polished) is a calcite marble of bluish-white color, with little bands or rows of spots of medium gray shade. It is of uneven texture, consisting of coarser white parts with grain diameter of 0.12 to 1 , mostly 0.25 to 0.62 millimeter, and thus of grade 5, and of finer dolomitic gray parts 
from 0.1 to 0.2 inch in width, and thus of grade 1 . The white parts contain some minute grains of quartz and of pyrite and minute black specks of uncertain nature. The gray spots and bands are graphitic. The marble takes a high polish, the dolomitic bands and spots standing out in minute relief.

The dark-gray banded marble of the 19-foot bed (specimen D, XXXI, 27, b, c) is a graphitic calcite marble, in some beds almost black, alternating with dark bluish-gray bands from 0.05 to 0.2 inch wide without plications, but in other beds of light-gray calcite marble alternating with similar bands of dark-gray shade. It has a grain diameter of 0.05 to 0.5 , mostly 0.12 to 0.37 millimeter, and is thus of grade 4. It is graphitic throughout but particularly so in the dark bands, and pyritiferous, with quartz grains rare and small, and limonite stain. This marble takes a high polish.

The variegated rock of the lowest bed is a graphitic calcite marble of very dark bluish-gray color, mottled or irregularly banded with very light bluish gray, almost bluish white, and of grade 4 .

The beds strike N. $10^{\circ} \mathrm{W}$. and $\operatorname{dip} 42^{\circ} \mathrm{W}$. A section of the graphitic schist (7-foot bed) shows it to be a sericite-quartz-graphite-calcite schist. It is finely plicated and crossed by slip cleavage and is veined with quartz, calcite, and pyrite. This is the typical schist of the base of the schist formation of the Taconic Range. The marble is cut by joints striking $\mathrm{N} .35^{\circ} \mathrm{W}$., dipping $45^{\circ} \mathrm{N} .55^{\circ} \mathrm{E}$., and spaced 3 to 7 feet. The marble beds at the surface are finely glaciated and the glacial polish has been preserved by a bed of clay which at the back of the quarry, over the small schist bed, is very graphitic and measures 7 feet in thickness, and a little farther west measures 30 feet and contains bowlders and sand.

The marble is used for construction. Specimen of "Clarendon A": The free-standing, iron-centered columns of the State Educational Building at Albany.

\section{RUTLAND QUARRIES.}

FOLEY PROSPECT.

The Foley prospect is about three-fourths of a mile west of the southeast corner of Rutland Township. The outcrop extends here and there, it is reported, into the township of Clarendon, toward a well-known bed of kaolin on the north bank of Cold River. Prospective operator, Edward H. Foley, 147 South Main Street, Rutland, Vt.

The beds, to judge from their geographic position, probably belong not far above the basal dolomite.

The marble (specimen D, XXXI, 86, a, polished) consists of alternating beds of very light gray calcite marble from 0.2 to 0.5 inch wide, alternating with irregular beds of very dark gray graphitic 
untwinned dolomite from 0.04 to 0.1 inch wide, both sets being most intricately plicated together. The calcitic parts polish well but the dolomitic not at all. Associated with these beds are also whitish calcitic marbles more faintly mottled with graphitic dolomite.

The beds are reported to lie in vertical position.

WEST RUTLAND QUARRIES, WEST SIDE.

EASTMAN QUARRY.

The Eastman quarry is at the east foot of the Taconic Range, on the west side of the West Rutland anticline, about 0.7 mile S. $10^{\circ} \mathrm{W}$. from the West Rutland station, in the township of West Rutland. (See Pls. I and IV and map of Castleton quadrangle, U. S. Geol. Survey.) The quarry, which was reopened a few years ago, now measures 126 feet north to south by 105 feet across (at the bottom) and is 135 feet deep. Operator, George P. Eastman, Rutland, Vt., or care of Tompkins-Kiel Marble Co., 505 Fifth Avenue, New York.

The marble exposed in and west of the quarry and by core drilling on both sides of it comprises the following beds, in natural order:

Section of marble beds at Eastman quarry.

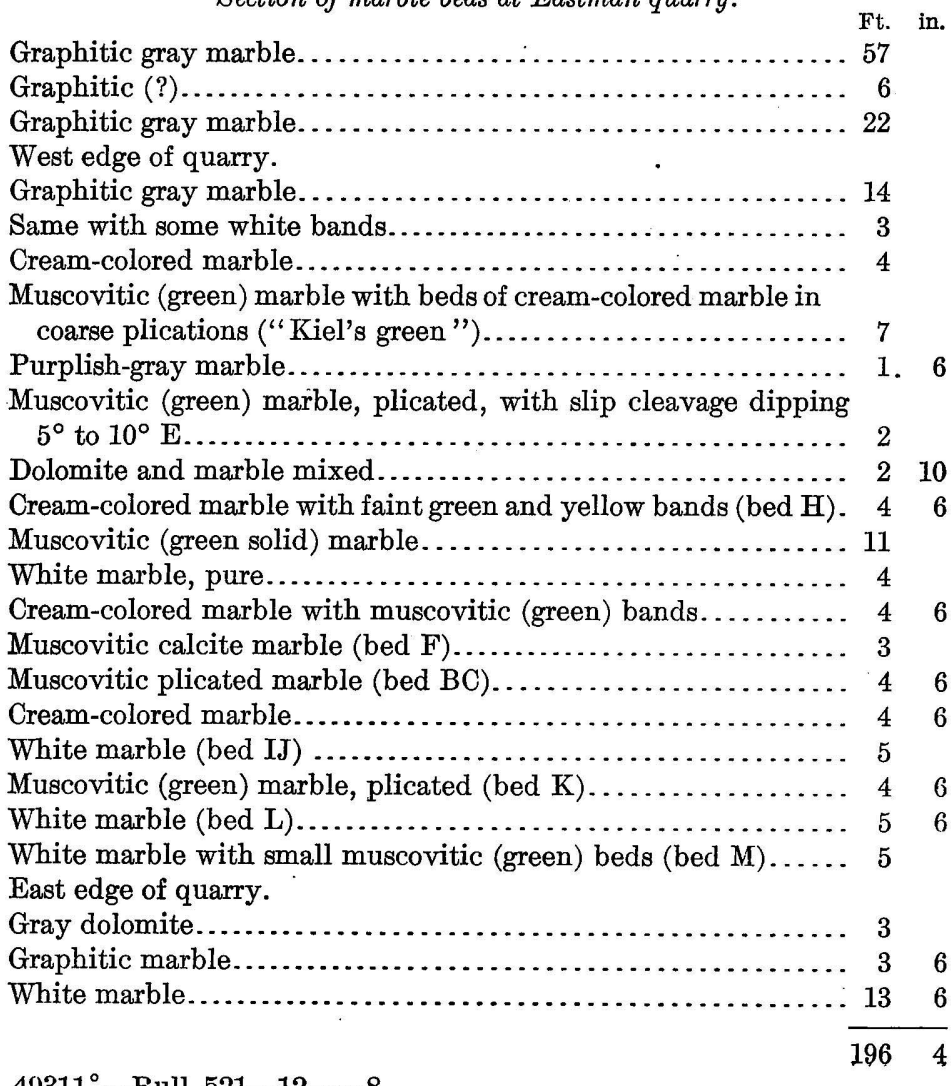

$49311^{\circ}-$ Bull. $521-12-8$ 
Eight of these marbles, the more important and typical ones, were examined microscopically.

"Eastman blue" (specimens D, XXXI, 29, b, rough; r, polished), the 14-foot bed, is a graphitic calcite marble of medium bluish-gray color and of even and fine texture, with grain diameter of 0.05 to 0.37 , mostly 0.12 to 0.25 millimeter, and thus of grade 3 (fine). The texture is peculiar in that the particles are elongate and the longer axes of the different grains are parallel, imparting some schistosity to the marble. (See fig. 6, p. 41.) The marble contains sparse quartz and muscovite grains. The polished specimen, which was cut across the bed, shows little beds alternately more and less graphitic and in places (by. the raised surface) dolomitic; all are in somewhat angular plications with a tendency to slip cleavage.

"Kiel's green" (specimens D; XXXI, 29, d; rough; 1, polished) consists of interbedded cream to flesh colored calcite marble of coarse irregular texture, with grain diameter of 0.05 to 1.5 millimeters and thus of grade 5, and of a bright greenish-gray schistose muscovitic and chloritic calcite marble of medium elongated texture, with grain diameter of 0.05 to 0.55 , mostly 0.12 to 0.37 millimeter, and thus of grade 4 . The cream-colored beds are from 0.5 to 1 inch thick and the green beds from 0.1 to 1 inch thick. Both are acutely plicated, the limbs of the plications reaching 5 inches in length, and crossed by slip cleavage. A small polished specimen is shown in Platê VIII, $A, b$. Both marbles contain extremely fine black particles of uncertain nature. The light beds abound in quartz grains up to 1.87 millimeters in diameter, contain some muscovite, and show the effect of secondary strain in bent twinning planes. The green beds contain some fine grains of quartz and its calcite grains are elongated and roughly parallel. In the lower part of the 7 -foot bed which furnishes this marble the light beds give place to the green ones and the marble becomes a solid greenish muscovitic calcite marble of medium texture (specimen D, XXXI, 29, g). Although the quartz of the light beds and the muscovite of the green ones interfere somewhat with the polish, the colors and designs of this marble are so unusual and attractive as to offset such imperfections.

A slightly purplish gray marble (specimen D, XXXI, 29, f) is a sericitic calcite marble with grain diameter mostly under 0.02 , rarely 0.37 millimeter, and thus between grades 1 and 2 . A little of the calcite is twinned. The rock contains abundant magnetite in plates and some quartz. The schistosity is parallel to the bed, with traces of secondary minute plications transverse to it.

"Green-veined cream statuary," bed H (specimens D, XXXI, $29, \mathrm{k}$, rough; $\mathrm{l}$, polished), is a calcite marble of delicate cream color in bands up to 2 inches thick alternating with slightly plicated bands (beds) of yellowish and very pale greenish tint up to 0.1 inch thick. 
It is even and regular in texture, with grain diameter like that of bed $\mathrm{F}$, averaging about 0.2 millimeter, and is of grade 3 . Exceedingly fine black specks occur sparsely throughout. The bands appear to be due to the oxidation of varying quantities of pyrite in very minute particles. The marble takes a high polish.

The green marble of the 11-foot bed, "solid green" (specimen D, XXXI, 29, e), is a muscovitic quartzose calcite marble of bright greenish-gray color and of irregular elongated parallel texture, with grain diameter of 0.02 to 0.3 , mostly 0.04 to 0.09 millimeter, and thus of grade 1 . The larger elongated and parallel grains are irregularly mingled with smaller ones of more or less roundish outline. Quartz is very plentiful. The muscovite is in scales and fibers.

"Cream statuary," bed F (specimens D, XXXI, 29, i, rough; m, polished), is a calcite marble of delicate cream color with very pale brown, minutely plicated beds up to 0.1 inch thick. It is even and regular in texture, with grain diameter of 0.05 to 0.37 , mostly 0.12 to 0.25 millimeter, and is thus of grade 3 . It contains rare small grains of quartz and sparse exceedingly minute black specks of uncertain nature. The stone takes a high polish.

"Light cipolin," bed BC (specimen D, XXXI, 29, o, polished), is a muscovitic calcite marble of light greenish-gray color in which the muscovite occurs in many close, fine, broadly plicated beds. In texture it belongs in grade 4. The polish is only fair because of the mica.

"Blanc clair," bed IJ (specimens D, XXXI, 29, h, rough; p, polished), is a calcite marble of milk-white to faintly clouded milk-white color and of irregular fine texture, with grain diameter of 0.04 to 0.42 , mostly 0.12 to 0.25 millimeter, and thus of grade 3 (fine). It contains sparse minute black grains, rare pyrite, and quartz, and takes a high polish. Its texture is less regular and a grade coarser than that of Rutland Italian (p. 119).

"Dark cipolin," bed K (specimens D, XXXI, 29, a, rough; n, polished), is a muscovitic calcite marble of generally bright lightgreenish color, with alternating more muscovitic (greenish) and more calcitic (whitish) little beds in broad plications 1 to 2 inches wide. Its texture is medium, with a grain diameter of 0.05 to 0.67 , mostly 0.12 to 0.37 millimeter, and it is thus of grade 3. The grain form is elongate and also irregular. There are quartz grains up to 0.37 millimeter, muscovite in scales and fibers, and chlorite mingled with a little epidote, besides some minute nodules (possibly titanite) and a little blue-green tourmaline. The green color is due mainly to the muscovite and chlorite. The polish is only fair owing to the mica.

The white marble with greenish bands of bed $M$ (specimen $D$, XXXI, 29, $\mathrm{j}$ ) is a calcite marble of milk-white color, with straight, parallel delicate green muscovitic beds from 0.1 to 0.4 inch wide. Its 
texture is regular and fine, with grain diameter of 0.05 to 0.5 , mostly 0.12 to 0.25 millimeter, and it is thus of grade 3 . It contains rare particles of quartz and sparse minute black grains of uncertain nature. The bands are largely sericite.

Owing to the variation in the proportion and arrangement of the accessory minerals in each bed the varieties of commercial marbles produced by this quarry are many.

The probable structure is shown in section E, Plate III. The beds strike N. $20^{\circ} \mathrm{W}$., but owing to a minor overturned fold they dip east $\left(35^{\circ}\right)$ instead of west and are therefore in inverse order. At the bottom of the quarry, 135 feet below the surface, they begin to turn, being almost vertical. The dolomite at the east edge of the quarry is described on page 30 .

The product is used mainly for interior decorative work, the blocks being shipped to Astoria, N. Y., where the cutting and polishing are done. Specimens: Interior of Greenpoint Savings Bank, Brooklyn, N. Y. (green beds); interior of Prudential Building, Newark, N. J. (green and cream-pink); mantels in United States Senate Office Building, Washington (cream and white); carved work border near ceiling and a large mantel, New York Public Library (cream and white); interior of Connecticut Savings Bank, New Haven, Conn. (white); interior of railroad station, Schenectady, N. Y.

\section{MORGAN QUARRY.}

The Morgan quarry is a few hundred feet north of the Eastman quarry. (See Pls. I and IV.) It has been recently reopened by the Vermont Marble Co. The beds are the same or very nearly the same as those at the Eastman quarry; the strike is N. $25^{\circ} \mathrm{W}$. and the dip vertical, changing to east. There is a very low eastwarddipping cleavage in some of the beds. An augite camptonite dike with a N. $65^{\circ}$ E. course cuts the beds near the quarry. (See further, p. 73.)

\section{UMBRELLA QUARRY.}

The Umbrella quarry, a disused opening belonging to the Columbian Marble Co., lies a few hundred feet north of the Morgan quarry. (See Pl. IV.) An 8-foot bed of fine-grained marble is exposed, striking N. $5^{\circ} \mathrm{W}$. and dipping $40^{\circ} \mathrm{E}$.

RUTLAND-FLORENCE QUARRY.

The Rutland-Florence quarry is about 300 feet north of the Umbrella, and is also out of use. It is owned by the Vermont Marble Co., Proctor, Vt. There are beds of white marble in the quarry, west of it lie 57 feet of beds covered by turf, and west of these are 70 feet of graphitic marbles. The strike in and west of the quarry is N. $15^{\circ} \mathrm{W}$. and the $\operatorname{dip} 35^{\circ} \mathrm{N} .75^{\circ} \mathrm{E}$. 
MCGARRY QUARRY.

At the McGarry quarry, a small disused opening south of the schoolhouse (see Pl. IV), graphitic marble about 10 feet thick overlies white marble, with a strike of N. $30^{\circ} \mathrm{W}$. and dip of $30^{\circ} \mathrm{N} .60^{\circ} \mathrm{E}$. Back of the schoolhouse and about 225 feet northwest of the quarry is a small anticline of dolomite 5 feet thick, the axis of which appears to pass west of the beds exposed in the quarry but may really pass east of it.

WEST RUTLAND QUARRIES, EAST SIDE.

VERMONT MARBLE CO.'S WEST RUTLAND QUARRIES.

The West Rutland quarries of the Vermont Marble Co. lie on the east side of the West Rutland anticlinal valley, along the west foot of the synclinal schist ridge which intervenes between the Taconic Range proper and the intermediate range. (See Pls. I and IV.) There are in all 11 openings, including the disused ones: Three (Covered quarry, New opening 1906, and Upper Gilson quarry) in an eastern upper series of beds, and eight (Gilson, Ripley, Baxter, a prospect, Clement, Foster, Sherman, and Old Open quarries) in an adjoining western and lower series of beds. Inasmuch as the slope of the schist and marble ridge near West Rutland bends around to the southeast, the quarries (with the exception of the Upper Gilson), although apparently in line, are on different sets of beds. The entire line, beginning at a point about 0.4 mile north-northwest of the West Rutland station, extends 0.8 mile north-northwest. These quarries will not be described in detail, as it will suffice to bring out the general facts concerning them all. They are narrow openings along the strike and follow the dip of the beds more or less closely, with foot and head walls dipping $35^{\circ}$ to $45^{\circ} \mathrm{E}$. In some places the supporting walls between the quarries have been excavated below, leaving narrow rock bridges at the top, as shown in Plate XII. As the beds turn eastward in synclinal attitude the quarrying has followed them, and by means of an irregular distribution of the supporting piers the Gilson, Ripley, and Baxter quarries have at the turn of the syncline, at a depth of 250 feet, been so combined as to admit of a continuous electric mine railroad 1,300 feet long. In the Ripley quarry, at a depth of 225 feet, tunneling has been done in a westerly direction for a distance of 340 feet, and in the Gilson quarry the beds have been followed eastward to a point 300 feet east of the west wall of the quarry.

The complete succession of the beds will be found in generalized form on page 86. Some of the best-known commercial marbles of these West Rutland quarries belong between the upper graphitic marble and the intermediate dolomite and occur as shown in the following 
section, beginning with the beds of the Upper Gilson quarry on the east in natural order:

Section of marble beds at West Rutland quarries of Vermont Marble Co.

White marble ("top white"), about. ........ Feet.

Graphitic (gray) marble.............................. $\quad 20$

White and graphitic (includes green bed, "olivo") ......... 50

White (includes "second statuary") .................... 3

Muscovitic, banded ............................. 4 4

White and graphitic ("monument," light cloud) ............ 6

White ("Rutland statuary"; only 4 feet thick east of turn in syn-

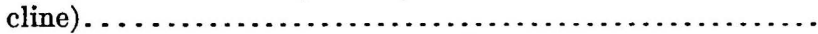

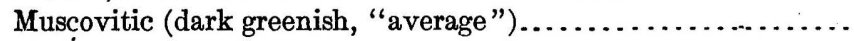

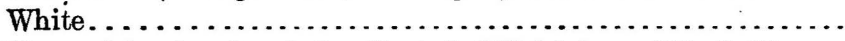

Muscovitic, fine banded; plicated ("light brocadillo,". "brocadillo," "pavonazzo").......................... 5-6

White ("mottled Smith," "best light cloud") ............ . 6-10

Muscovite banded ("Jackman," "light Smith," "listavena")... 4

White .................................... $1-4$

Muscovitic, banded (dark greenish, "hard layer," "verdoso")... 2-4

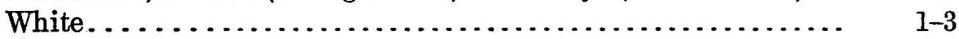

Dolomite....................................... $1-4$

Muscovitic, banded ("double belt") ................ 2-3

White ("Rutland Italian") . . . . . . . . . . 3 .6.

Graphitic, with abundant Maclureas in upper part ("dark blue," "extra dark blue," "livido") .................... 8-25

Dolomite ................................. 40

220-262

Graphitic marbles are worked for 300 feet west of and below this series, in the west tunnel of the Ripley quarry. Core drilling has.also been done west from the west end of that tunnel, exposing the following succession:

Section of marble beds west of west tunnel of Ripley quarry.

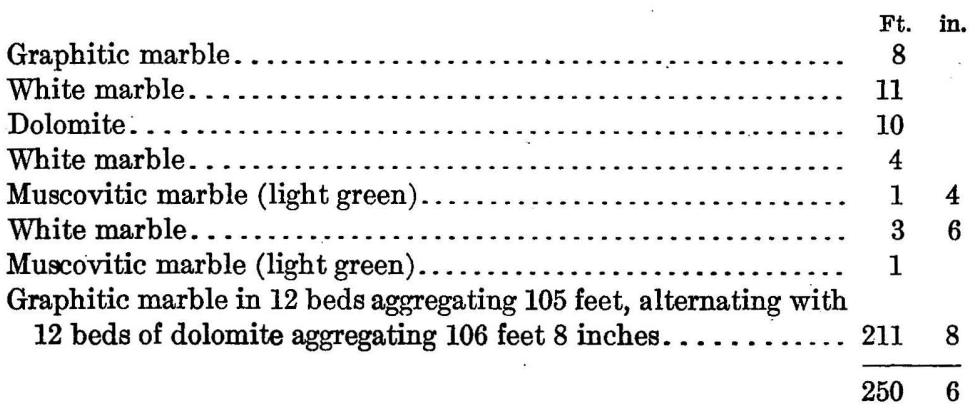

A number of the marbles have been examined microscopically with these results: "Statuary Rutland" (specimen D, XXXI, 80, b), is a calcite marble of milk-white color and of very fine, regular, some- 
what even texture, with grain diameter of 0.05 to 0.5 mostly 0.07 to 0.25 millimeter. By the use of the Rosiwal method the average diameter was found to be exactly 0.1 millimeter and the texture is therefore of grade 2 (very fine). A camera-lucida sketch of a thin section of this marble is reproduced in figure 16. There are rare grains of quartz and plagioclase feldspar and infinitesimal opaque particles of irregular form, some of which, to judge from the effect of a magnet on the powdered marble, are magnetite. The marble takes a high polish.

The "second statuary Rutland" (specimen D, XXXI, 80, c), is a calcite marble of milk-white color with faint grayish-yellow clouds and of fine, somewhat irregular texture, with grain diameter of 0.05 to 0.57 , mostly 0.12 to 0.25 millimeter, and thus of grade 3 (fine). It contains minute sparse black particles and very rare quartz grains. The polish is high.

"Rutland Italian" (specimens D, XIX, 143, b, rough; D, XXXI, 80, $\mathrm{d}$, polished) is a calcite marble of faintly bluish white color with faint irregular grayish and yellow-brownish mottlings. The mottling is more pronounced than in the "second statuary." It is somewhat irregular in texture, with grain diameter of 0.05 to

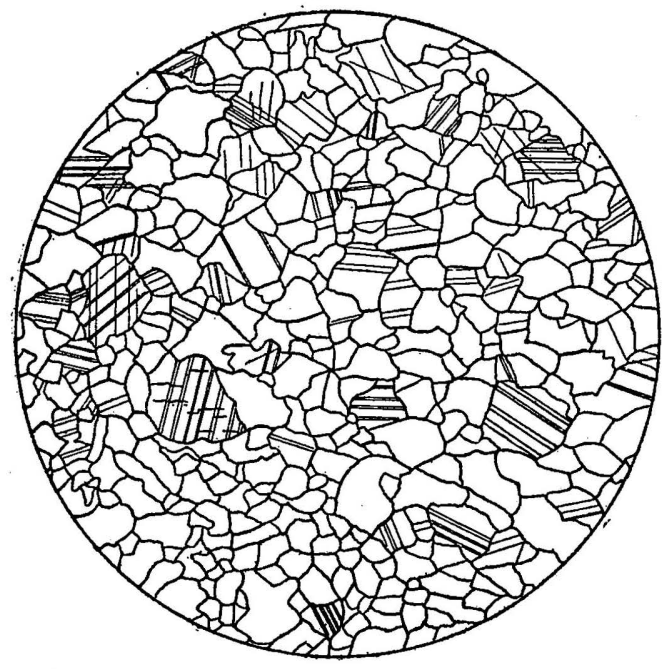

FIGURE 16.-Thin section of white calcite marble, "statuary Rutland," of texture grade 2. Enlarged 27 diameters.

0.87 , mostly 0.12 to 0.5 millimeter, and thus of grade 4 . It contains minute black specks and some spherules of pyrite, some quartz grains, and rare scales of muscovite. The polish is high.

"Dark-blue Rutland" (specimens D, XXXI, 80, a, rough; k, polished) is a graphitic calcite marble of dark bluish-gray color mottled with white, apparently in fine plications, and with some fine black streaks. Its texture is irregular, with a grain diameter of 0.05 to 0.57 , mostly 0.12 to 0.25 millimeter, and it is thus of grade 3 (fine). It contains minute grains of graphite and rare scales of muscovite. It takes a high polish. This is the bed which carries in places sections of Maclureas (see p. 22) in white calcite.

A section of "extra dark blue" obtained in 1900 is of similar irregular texture, with grain diameter of 0.025 to 0.37 , mostly 0.075 to 
0.175 , and averaging possibly about 0.11 millimeter and thus of grade 2 .

"Brocadillo" (specimens D, XXXI, 80, e, polished; D, XIX, 143, c, rough) is a muscovitic calcite marble of faintly greenish-white ground, with fine greenish-gray plicated beds and straight streaks (cleavage planes?) to 0.2 inch wide. Its texture is irregular, in places elongated parallel, with grain diameter of 0.05 to 0.62 , mostly 0.12 to 0.37 millimeter, and it is thus of grade 4 (medium). The accessory minerals, in descending order of abundance, are quartz, with some feldspar (plagioclase), up to 0.62 millimeter in diameter, muscovite in scales and fibers, epidote with a little zoisite, brownish translucent lenses (carbonate?), chlorite, minute spherules and crystals of pyrite, and still more minute opaque particles (pyrite?). The marble takes a high polish, to which the sparseness of the micaceous bands contributes.

"Livido," from the bottom "blue bed" (specimen D, XXXI, 80, i), is a slightly graphitic calcite marble of medium to delicate light bluish-gray shade, with plicated dark-gray dolomitic beds up to 0.1 inch wide. Its texture is irregular and uneven. The calcitic parts have grain diameter of 0.05 to 0.62 , mostly 0.1 to 0.25 millimeter, and are thus of grade 3 (fine), but the dolomite has grains measuring 0.009 to 0.02 millimeter and is thus of grade 1 (extra fine). The dolomite is very irregularly distributed in the more graphitic little beds. No mica or quartz was detected. The polish is high.

"Olivo" (specimen D, XXXI, 80, h) is a muscovitic calcite marble of light greenish-gray and pale greenish-white color, in undulating bands up to half an inch thick, and of an elongated parallel texture, with grain diameter of 0.07 to 0.75 , mostly 0.12 to 0.37 millimeter, and thus of grade 4 (medium). Besides muscovite it contains plentiful quartz, rarely a grain of feldspar (plagioclase), some irregular minute, barely translucent lenses (carbonate?), and very minute black specks. This marble is more micaceous than the "brocadillo" and its general color resembles that of specimens $29, \mathrm{n}$ and $\mathrm{o}$, from the Eastman quarry. The polish is fair but poor where mica abounds.

The following were not studied microscopically: "Verdoso" (specimen $\mathrm{D}, \mathrm{XXXI}, 80, \mathrm{~g}$ ) is a muscovitic calcite marble with minute plicated dark-greenish beds on a white ground. It may contain chlorite. The texture is medium and the polish poor.

"Rubio" (specimen D, XXXI, 80, f) is a calcite marble of very delicate pinkish tint, with thin plicated greenish muscovitic beds. The pinkish tint proceeds presumably either from a mineral containing manganese oxide or from hematite, possibly due to oxidation of magnetite, but in either case in very minute particles. Its texture is fine and its polish good. 
"American pavonazzo" (specimen D, XXXI, 80, j) is a calcite marble with milk-white ground and chloritic dark blue-greenish plicated beds of irregular width and distribution. The polish is good except over the chloritic beds. The mantel and wainscoting in Plate $\mathrm{XIV}, B$, are made of this marble.

An analysis of the graphite in the "dark-blue Rutland" is given on page 40 and one of the white marble on page 12. The following analyses of the blue, white, and statuary are quoted here for reference:

Analyses of marbles from Vermont Marble Co.'s quarries at West Rutland.a

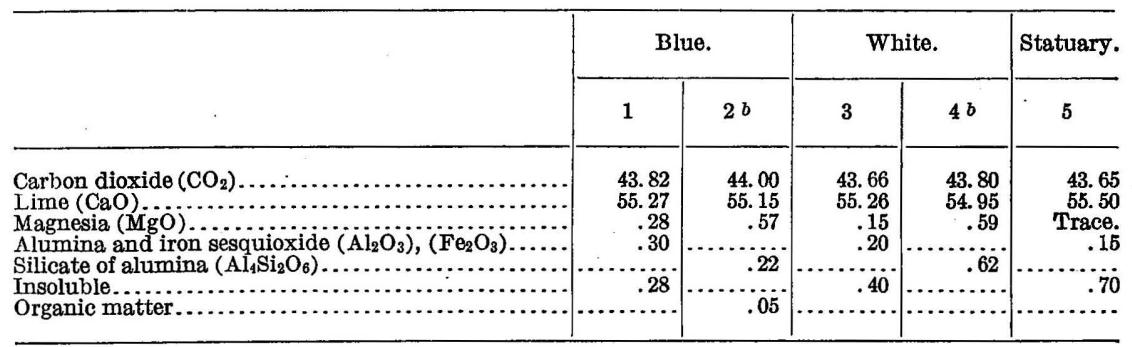

$a$ Day, W. C., Eighteenth Ann. Rept. U. S. Geol. Survey, pt. 5, continued, 1897, p. 985.

$b$ Analyses by J. N. Harris.

The following compression tests were made at the United States arsenal at Watertown, Mass., April 1, 1893:

Compression tests of marble from West Rutland quarries.

\begin{tabular}{|c|c|c|}
\hline No. & Marble. & $\begin{array}{l}\text { Compressive } \\
\text { strength } \\
\text { (pounds } \\
\text { per square } \\
\text { inch). }\end{array}$ \\
\hline $\begin{array}{l}9061 \ldots \ldots \ldots \\
9063 \ldots \ldots \ldots\end{array}$ & 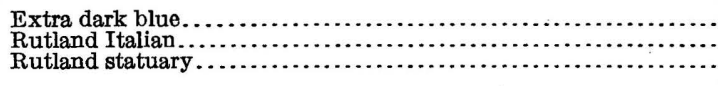 & $\begin{array}{l}13,639 \\
14,068 \\
11,525\end{array}$ \\
\hline
\end{tabular}

The following transverse tests were made at the same place in November, 1895. The blocks were supported 20 inches apart and loaded in the middle.

Transverse tests of marble from West Rutland quarries.

\begin{tabular}{|c|c|c|}
\hline No. & Marble. & $\begin{array}{l}\text { Modulus of } \\
\text { rupture per } \\
\text { square inch. }\end{array}$ \\
\hline 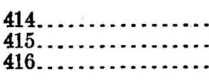 & 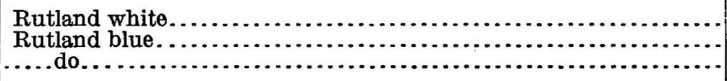 & $\begin{array}{l}1,202 \\
2,069 \\
2,045\end{array}$ \\
\hline
\end{tabular}

The following shearing tests were made at the same time and place. The distance between supports was 6 inches, the width of block to which pressure was applied 5 inches, and the thickness of block tested 6 inches. 
Shearing tests of marble from West Rutland quarries.

\begin{tabular}{|c|c|c|c|c|c|}
\hline No. & Marble. & $\begin{array}{l}\text { Shearing } \\
\text { area } \\
\text { (square } \\
\text { inches). }\end{array}$ & $\begin{array}{l}\text { Transverse } \\
\text { fracture } \\
\text { developed } \\
\text { (pounds). }\end{array}$ & $\begin{array}{l}\text { Shearing } \\
\text { strength } \\
\text { per square } \\
\text { inch } \\
\text { (pounds). }\end{array}$ & $\begin{array}{l}\begin{array}{l}\text { Surfaces } \\
\text { sheared. }\end{array} \\
\text {. }\end{array}$ \\
\hline $\begin{array}{l}272 \ldots \\
273 \ldots \\
274 \ldots \\
275 \ldots\end{array}$ & 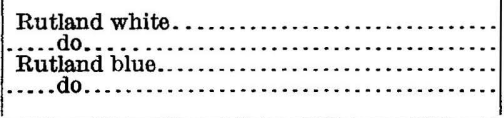 & $\begin{array}{l}47.72 \\
48 . \\
48.32 \\
48.04\end{array}$ & $\begin{array}{l}18,400 \\
18,200 \\
20,600 \\
22,100\end{array}$ & $\begin{array}{r}1,100 \\
946 \\
1,519 \\
914\end{array}$ & \\
\hline
\end{tabular}

Tests of expansion made at the Watertown Arsenal in November, 1895, determined the coefficient of expansion in water per degree Fahrenheit of Rutland white marble as 0.00000312 inch; that of the mottled marble of the Proctor quarry was 0.00000550 inch, and that of a dark graphitic marble from the Shangrow quarry was 0.00000433 inch. These tests were made in water baths between temperatures of $32^{\circ}$ and $212^{\circ} \mathrm{F}$. The transverse strength was found

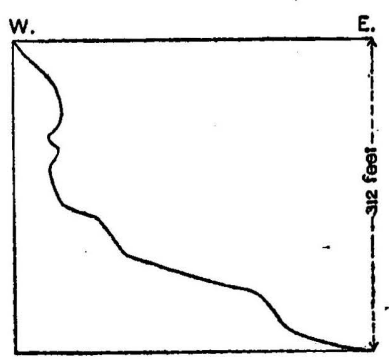

Frgure 17.-Course of east limb of the West Rutland anticline or the west limb of the syncline. to be greatly lowered by such treatment. The probable general structure of the West Rutland anticline is given in sections $\mathrm{B}$ and F, Plate III. The quarries lie on the east limb of the anticline, the top of which has been eroded, or along the west limb of a syncline of marble overlain by schist. In passing from quarry to quarry along the strike, the supports left between the walls and also between adjacent quarries show on their smoothly cut surfaces various minor undulations in the limb of the syncline, so that in a series of cross sections of the limb 200 feet apart no two would be identical. Here and there a little faulting or pinching out of smaller beds is also evident. Figure 17 shows the approximate character of the anticlinal or synclinal limb at the Ripley quarry. The steeper upper part of it is also shown in Plate XII. At the prospect (quarry No. 7 on map, Pl. IV) a trap dike 10 inches to 6 feet wide cuts the marble beds with a N. $60^{\circ} \mathrm{E}$. course and a dip ranging from steep to $30^{\circ} \mathrm{S} .40^{\circ} \mathrm{E}$. The dike has a glassy rim 0.12 inch wide, weathered whitish. The presence of many joints on the south side parallel to the dike wall probably caused the discontinuance of the quarry.

The marbles from these quarries serve a great variety of purposes. Many of the beds are used for interior decoration panels, wainscoting, etc., some for interior or exterior carving, and others for construction. Some of the graphitic marbles are in demand for electric switchboards. Among the more notable buildings and attractive monuments of recent date made of the marble of these quarries are 


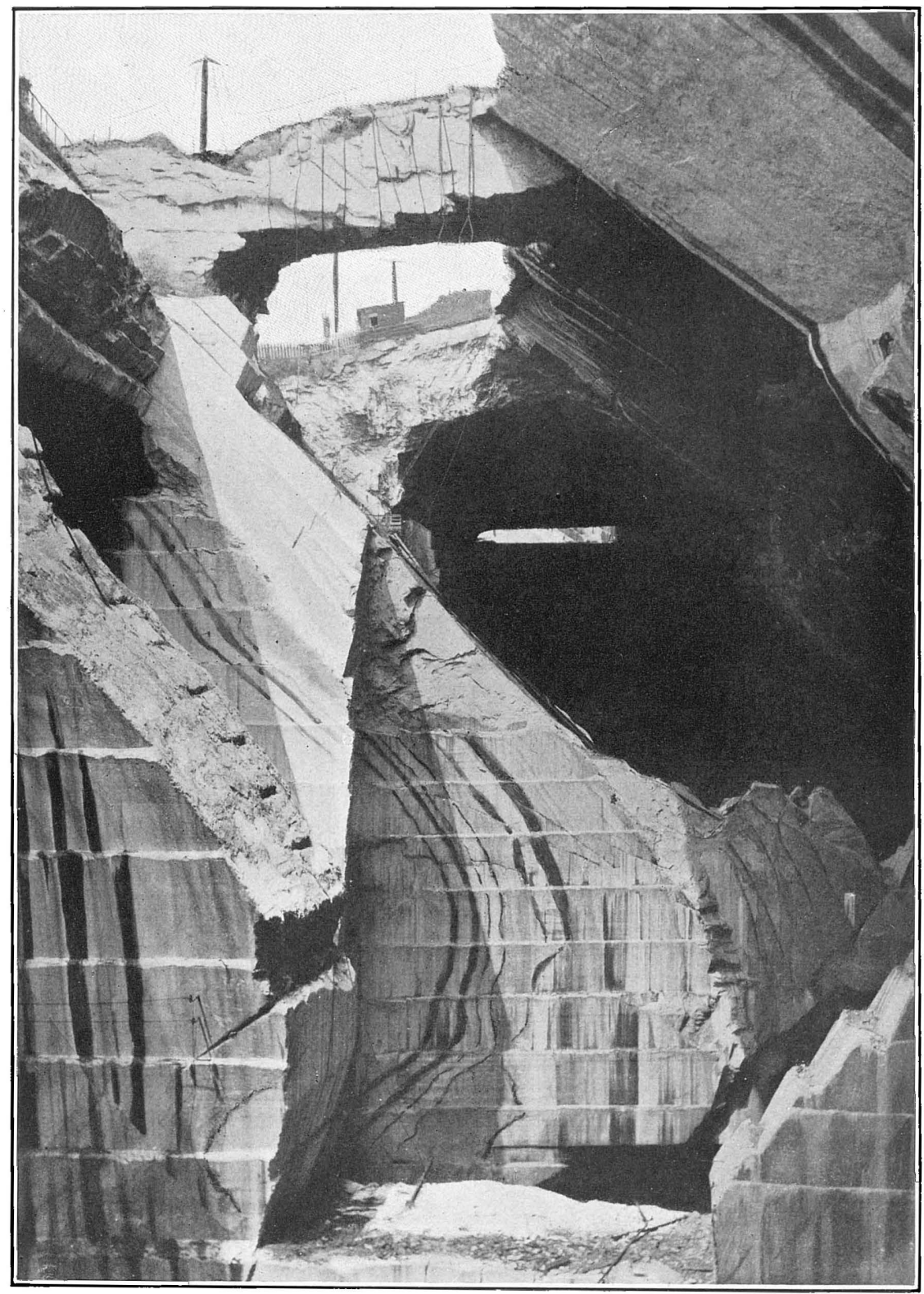

VIEW FROM THE SOUTH WALL OF THE GILSON QUARRY, WEST RUTLAND, AT A POINT 70 FEET BELOW THE SURFACE.

Showing part of the east limb of the West Rutland anticline and three of the quarry openings. Vertical black streaks at the left due to smoke. 


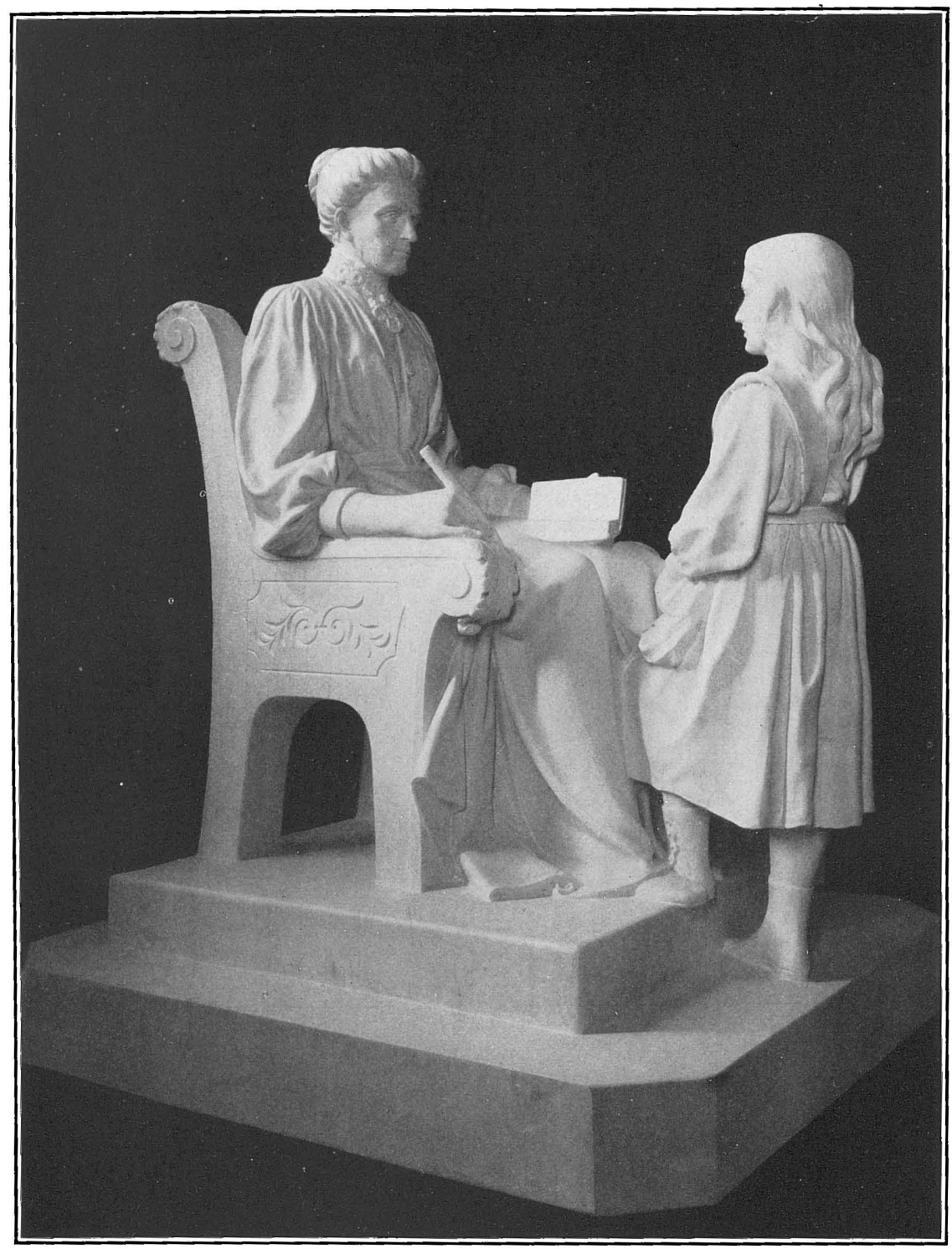

WILSON PORTRAIT STATUE, SEATTLE, WASH.

White calcite marble, "light Rutiand Italian." 
the Senate office building, Washington, from West Rutland marble, with some from Danby; the marble and statues of the Chamber of Commerce Building, New York, from West Rutland marble; the Wilson portrait statue at Seattle, Wash. (Pl. XIII), of "light Rutland Italian;" the Taylor mausoleum, Woodlawn Cemetery, New York, of "best white Rutland building marble;" the Kimball monument at Graceland Cemetery, Chicago (Pl. XIV, $A$ ), of "second statuary" and the mantel and wainscoting in the First National Bank, Hazleton, Pa. (Pl. XIV, B), of "American pavonazzo."

\section{ALBERTSON QUARRY.}

The Albertson quarry (formerly known as the Esperanza) is also on the east side of the West Rutland anticlinal valley, $2 \frac{1}{4}$ miles northnorthwest of West Rutland station in the township of West Rutland. (See Pls. I and IV and map of Castleton quadrangle, U. S. Geol. Survey.) The quarry measures 500 feet in a N. $17^{\circ} \mathrm{W}$. direction by 110 feet across and 115 feet in depth. An area 150 by 110 feet at the north end is worked out as far down as a certain dolomite bed. There is a tunnel, 80 to 175 feet wide and 40 feet high, on the west side, extending about 630 feet in a N. $30^{\circ} \mathrm{W}$. direction and reaching a point 75 feet west of the west wall of quarry. Operator, Vermont Marble Co., Proctor, Vt.

The marble exposed and explored here consists of the following beds:

Section of marble beds at Albertson quarry.

Feet.

Graphitic marble................................... 135

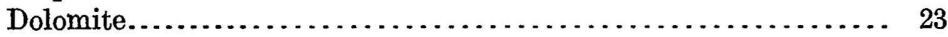

Marble, some of it greenish.......................... 19

Dolomite....................................... 22

199

The marble, "extra dark Albertson" (specimens D, XXXI, 26, a, b, polished), is a graphitic calcite marble of medium bluish-gray shade, with thin, minutely plicated black streaks (beds) and here and there whitish streaks of like character, both crossed at various angles by cleavage planes slightly undulating and also black. A piece of this marble is shown in Plate VIII, $B, b$. The texture is regular, with grain diameter of 0.05 to 0.62 , mostly 0.17 to 0.37 , millimeter, and it is thus of grade 4 (medium). It abounds in graphite, particularly along the little black beds and the planes of slip cleavage, and contains rare minute cubes of pyrite and still more muscovite scales and quartz grains. The amount of graphite in it is probably like that in the West Rutland blue (p. 40). The marble takes a high polish without dolomitic protuberances.

The beds strike about N. $25^{\circ} \mathrm{W}$. The north wall shows a syncline in cross section, and for about 400 feet south of that point the syn- 
cline pitches $10^{\circ}$ about north, and then for 130 feet $5^{\circ}$ about south. On the north face of a jog in the west face near the south end the west limb of this syncline dips $15^{\circ}$ to $20^{\circ} \mathrm{E}$. The tunnel, which makes an angle of $13^{\circ}$ with the west wall of the quarry, follows the axis of a syncline. About 315 feet from that wall this syncline on its west side strikes $\mathrm{N} .35^{\circ}-40^{\circ} \mathrm{W}$. and dips $28^{\circ} \mathrm{E}$., and its east side also dips at a low angle. The entire width of the syncline is about 200 feet and it opens northward. The beds on the east wall of the quarry are crossed by a conspicuous slip cleavage dipping $20^{\circ}-30^{\circ}$ east or southeast. (See for general structure Pl. III, section C.)

The marble of this quarry is used largely for monumental and electric work, but some for construction. St. Ann's Roman Catholic Church at Fall River, Mass., is made of it.

\section{TRUE BLUE QUARRY.}

The True Blue quarry is also on the east side of the West Rutland anticlinal valley, three-fourths of a mile north-northwest of the Albertson, and 3 miles north-northwest of West Rutland station, in West Rutland Township. (See Pls. I and IV and map of Castleton quadrangle, U. S. Geol. Survey.) The quarry is about 112 feet north to south by 100 feet east to west in its southern half and 75 feet in the northern half, and about 100 feet deep. From the south wall, at a point 75 feet below the surface, a tunnel, 50 to 75 feet wide and 30 to 40 feet high, extends 113 feet southward, to a point where its floor is about 130 feet below the surface.

Operator since May, 1911, Vermont Marble Co., Proctor, Vt.

The marble beds exposed and explored here consist of the following:

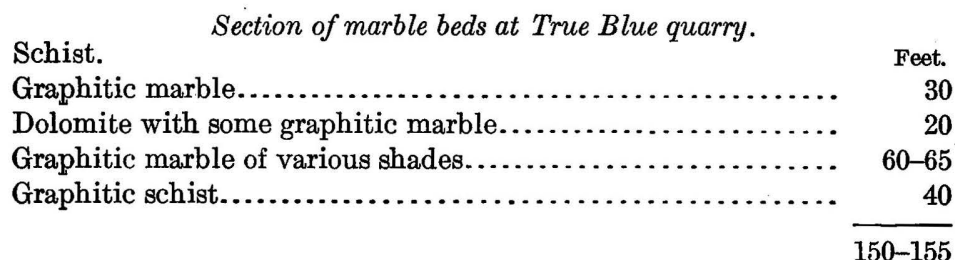

The marble, "True Blue" (specimens D, XXXI, 25, c, rough; 25, $\mathrm{b}$, and XIX, 138, d, e, polished), is a graphitic calcite marble of medium-gray shade, with more or less finely plicated black (graphitic) bedding planes crossed at various angles by slightly flexed slipcleavage planes, also black and graphitic. A photograph of a slab showing this feature is reproduced in Plate V, $A$. Its texture is even, regular, and on the fine side of medium, with grain diameter of 0.05 to 0.75 , mostly 0.12 to 0.37 millimeter, and thus of grade 4 . It abounds in graphite in minute grains and contains a few minute cubes of pyrite and rare and small grains of quartz. It takes a high polish without dolomitic protuberances. 


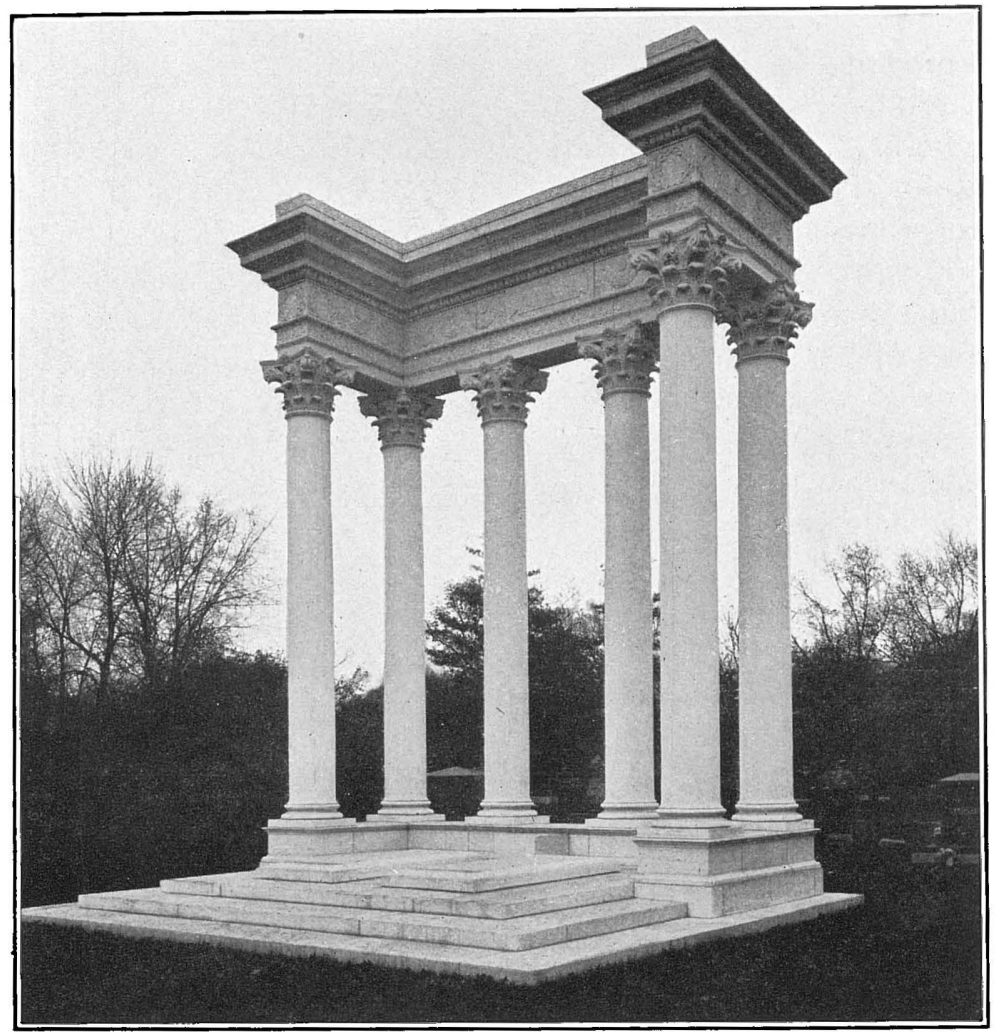

A. Kimball monument, gRaCeland CEMETERY, CHICAGo, ILL. Columns of "second statuary Rutland" calcite marble.

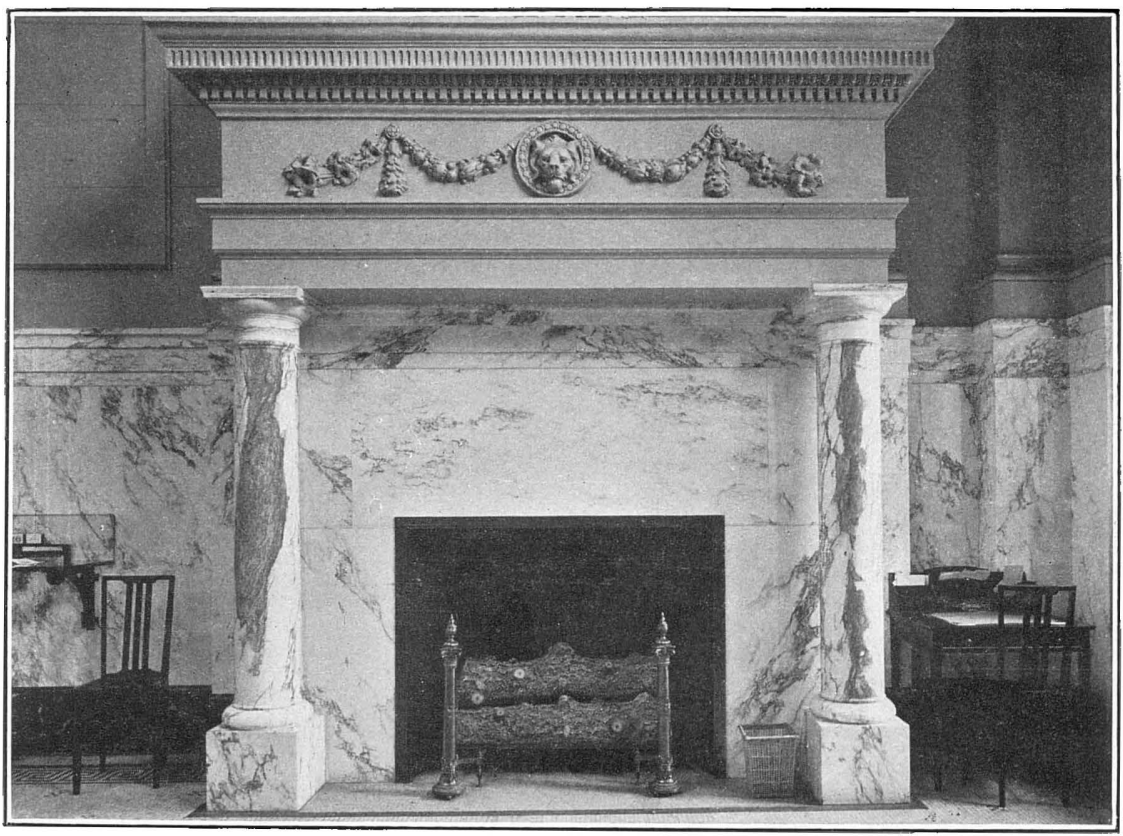

B. MANTEL AND WAINSCOTING IN FIRST NATIONAL BANK, HAZLETON, PA. Muscovitic calcite marble, "American pavonazzo," from West Rutland. 


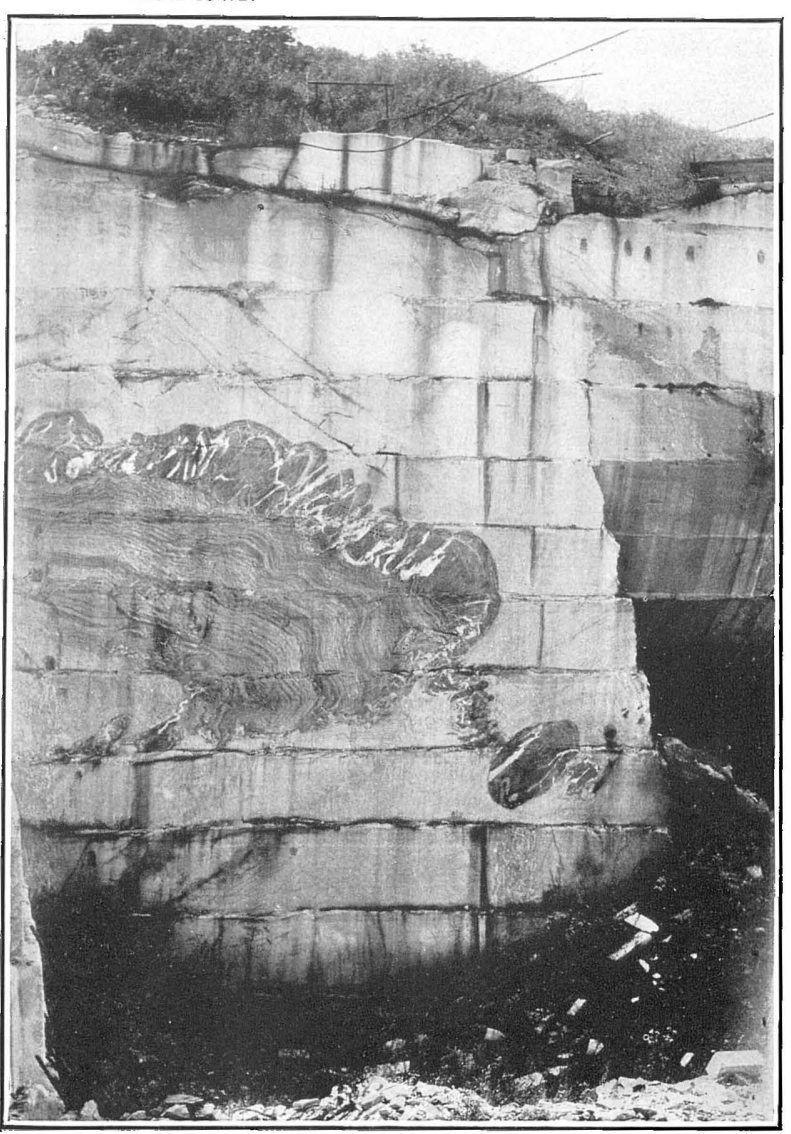

A. SOUTH WALL OF TRUE BLUE QUARRY, WEST RUTLAND.

Westward-dipping beds of graphitic calcite and dolomite marble. The upper part of the 15-foot bed, consisting of very dark dolomite veined with calcite and quartz, passes into a series of nodules. The lower part of the bed age. The large nodule is 3 by 2 feet

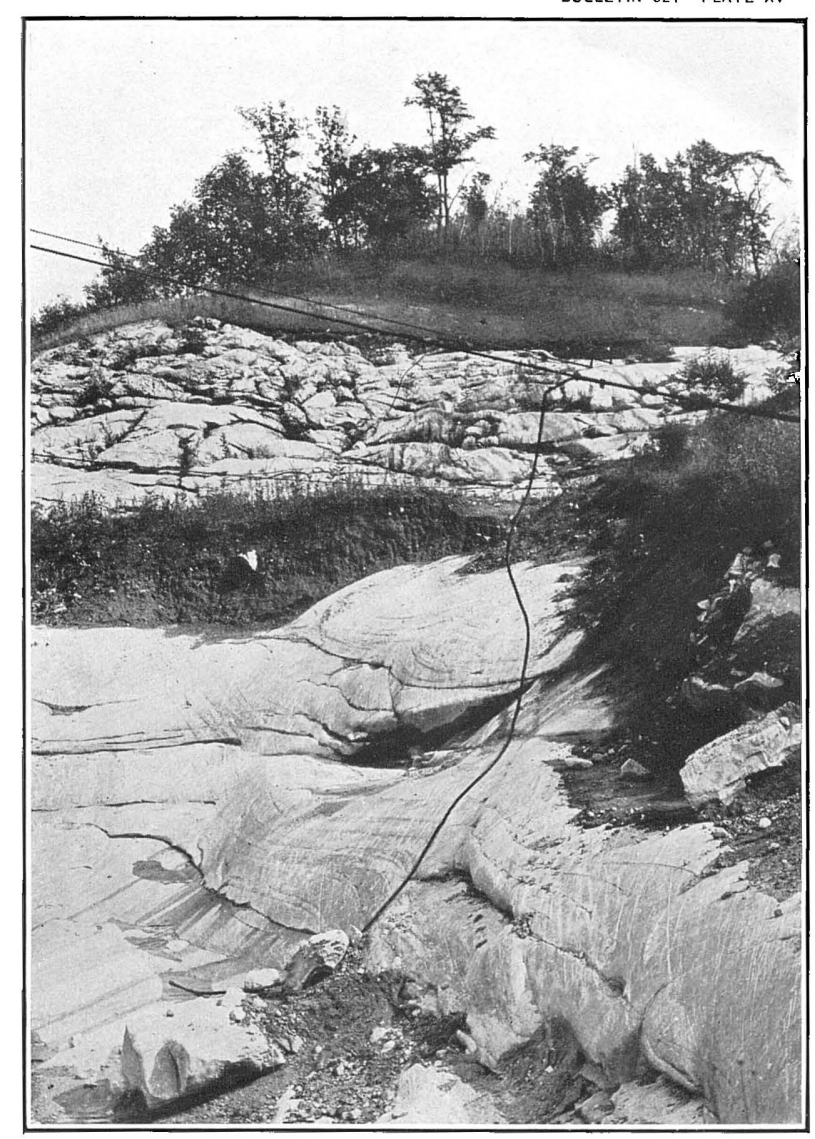

B. RECENTLY UNCOVERED GLACIATED BEDS OF GRAPHITIC CALCITE MARBLE AT FLORENTINE QUARRY, PITTSFORD.

Looking $S .32^{\circ}$ E., nearly along the strike of the beds. 
As will be seen by the geologic map, the quarry is very near a southward-pointing tongue of schist. In 1900 the north wall of the quarry was at the south end of this synclinal tongue. The structure on the north wall of the present quarry ( 75 feet south of the old north wall) shows four minor folds overturned toward the east in a space of about 70 feet and these folds consist of graphitic marble, dolomite, and schist about 50 feet below the rock surface. This is probably the same schist which reappears at the bottom of the tunnel and which has been core drilled to a depth of 40 feet. On the south wall (as shown in $\mathrm{Pl}$. XV, $A$ ) east of the tunnel a 15-foot bed of graphitic dolomite veined with white (calcite and quartz probably) dips west, toward the tunnel, but has been partly faulted out along an eastwarddipping cleavage foliation and partly pinched out during elongation and flowage and has been transformed into a series of oblong or spherical nodules of graphitic dolomite up to 3 by 2 feet, which continue in the direction of the dip within the quarry. The approximate structure at this quarry is shown in figure 18. The general structure is

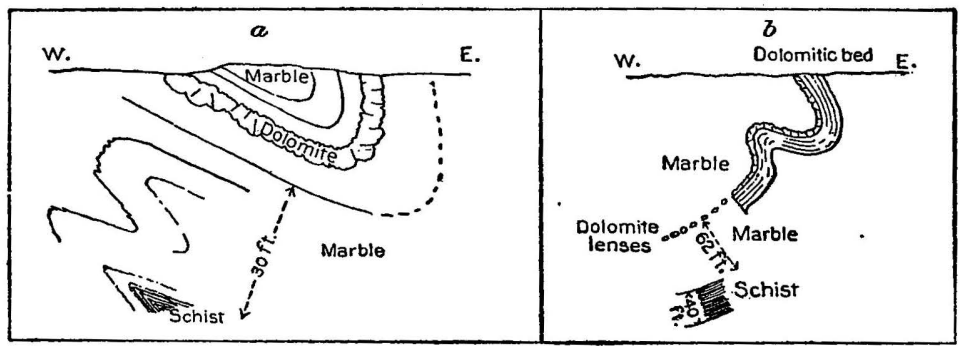

FIGURE 18.-Approximate structure at True Blue quarry. $a$, Structure on north wall; $b$, general relations in quarry and on south wall.

shown in section D, Plate III. The pitch of this whole series here is about $15^{\circ} \mathrm{S}$. and the slip cleavage in the marble dips $30^{\circ} \mathrm{E}$. This structure is shown in the slab pictured in Plate $\mathrm{V}, A$. The proximity of the schist tongue shows that the beds here belong to the uppermost part of the upper graphitic series, and the presence of the lower schist bed shows that during the closing part of the period of calcareous deposition argillaceous sediments alternated with calcareous sediments for a time before crowding out the latter altogether. The presence of such schist beds near the top of the limestone formation is not unusual along the Taconic Range. They should not be confounded with synclinal tongues or lenses belonging to the main schist mass itself. Marble should recur below the schist bed of the True Blue quarry.

The schist of the top of the 40-foot bed is very graphitic and contains veins and lenses of pyritiferous quartz parallel to its schistosity. The schist consists of stringers of muscovite and chlorite with graphite 
and quartz, rarely a grain of feldspar (plagioclase). It is a pyritiferous graphite-calcite-quartz-muscovite-chlorite schist.

About 300 feet south of the south wall of the quarry is a 4-foot trap dike with a $\mathrm{N} .70^{\circ} \mathrm{E}$. course, and many joints parallel to it occur in a space of 30 feet on its north side.

\section{PROCTOR.}

\section{RIVERSIDE QUARRY.}

The recently opened Riverside quarry is 2 miles south of Proctor station, between Otter Creek on the west and the railroad on the east, in the township of Proctor. (See Pls. I and IV and map of Castleton quadrangle, U. S. Geol. Survey.) It is about 100 feet square and 70 feet deep. Operator, Vermont Marble Co., Proctor, Vt.

Assuming that the dip of $60^{\circ}$, which is that of the beds exposed in the quarry, prevails throughout the 200 feet of marble which has been core drilled west of it, the marble here measures 255 feet and is close to the top of the dolomite, which crops out a little farther east. Some 100 feet of marble beds have been explored between the east edge of the quarry and the dolomite, but as the dolomite and overlying marble a little to the south dip west, most of these beds are probably continuations of those in the quarry.

The marble, "Riverside" (specimens D, XXXI, 15, a, rough; b, polished), is a coarse calcite marble of translucent, slightly bluish white color, with dark-gray spots and bands at irregular intervals along the planes of bedding, and of uneven texture, with grain diameter in the white calcitic ground of 0.05 to 1.0 , mostly 0.25 to 0.5 millimeter, and thus of grade 5 (coarse). The thin sections did not cross any of the dark spots. That these spots are largely dolomite is evident from their standing out in minute relief on the polished face and being easily scratched with a knife; and that they are also graphitic is evident from the nature of other similar clouded marbles. The average grain diameter in the dolomitic passages would be about 0.05 to 0.1 millimeter. The calcitic parts contain sparse quartz particles, some up to 0.32 millimeter, and also pyrite, some of which is oxidized.

The marble beds strike N. $5^{\circ} \mathrm{W}$. and dip $60^{\circ} \mathrm{E}$. The dolomite along the base of the Pine Hill ridge one-fourth mile southeast of the quarry has a like strike but dips about $50^{\circ} \mathrm{W}$., and the marble at an idle quarry a little south and west of the dolomite boundary strikes N. $15^{\circ}$ W., dips about $67^{\circ} \mathrm{W}$., and has an exposed thickness of 90 feet. Unless faulting intervenes a synclinal axis passes between these two quarries. The marble surface at the Riverside quarry had a glaciated surface protected by a covering of till. Glacial potholes 10 to 15 feet by 6 to 8 feet were found, and near the old quarry to the south-southeast are others 8 to 10 feet in diameter. 
COLUMBIAN QUARRY.

The Columbian quarry, in operation in 1900, was idle for some time prior to August, 1910, but was then about to be reopened. It is about three-fourths of a mile south-southwest of Proctor station in Proctor Township. (See Pl. I.) It is 100 feet or more in diameter and 150 feet deep. Operator, New Columbian Marble Co., State Street, Rutland, Vt.

The marble is white clouded. The beds strike N. $10^{\circ}-15^{\circ} \mathrm{W}$. and dip $50^{\circ} \mathrm{E}$. A complete analysis of the stone is given on page 13.

About 100 feet north of the quarry along the strike the same beds, recently uncovered, with a glaciated surface and pothole 5 feet by 4 feet 6 inches, strike N. $20^{\circ} \mathrm{W}$. and dip very steeply to the east. The marble exposed measures about 60 feet. East of it is the boundary of the dolomite series.

The general structure on both sides of the quarry is shown in section H, Plate III.

\section{PROCTOR QUARRY.}

The Proctor quarry, in full operation in 1900 but idle since 1907 and full of water in 1910, is about 0.4 mile northwest of Proctor station, on the north side of the village, a mile north of the Columbian quarry. (See Pl. I.) It is about 200 feet square, with an offset on the east side, and in 1900 was 175 feet deep. Owner, Vermont Marble Co., Proctor, Vt.

Marble 70 to 185 feet thick is exposed, lying between the uppermost bed of the dolomite series on the east and the intermediate dolomite on the west.

The marble, "Sutherland Falls" (specimens D, XIX, 140, c, dd), is a calcite marble of bluish-white color with thin dark-gray spots and bands, probably dolomitic, along the bedding plane. Its texture is uneven and of grade 5 (coarse). It resembles very closely the "Riverside" marble, described on page 126.

The general structure is shown in section G, Plate III. The marble beds form the eastern limb of a syncline about 150 feet in depth, but, instead of curving over directly on the east to form an anticline, they turn sharply to dip at a low angle to the east for a space of 50 feet and then turn again to resume the direction of the synclinal limb. The effect of this minor fold in the anticlinal part of the fold is to double over some of the marble beds in the lower eastern part of the quarry and reduce the apparent thickness. Between 1900 and 1907 the quarry was also worked toward the east. The section on the north wall of this eastern extension shows the eastward-dipping beds of this minor easterly overturned fold crossed by low eastward-dipping joints, along which several caves as much as 3 feet in height have been eroded by percolating water. The dolomite which overlies the 
marble on the west differs microscopically from that of the dolomite series which underlies it on the east. (See p. 30.)

It is reported that the reasons for abandoning this quarry were the abundance of joints and the thinning of the beds at the turn of the syncline.

\section{PARKER \& PINCKNEY PROSPECT.}

The Parker \& Pinckney prospect, tested in 1910, is $1 \frac{1}{2}$ miles north of Proctor and $1 \frac{3}{4}$ miles south-southwest of Pittsford village, in Proctor Township. (See Pl. I.) Operators, Parker \& Pinckney, Pittsford, Vt.

The marble (specimen D, XXXI, 53, C) is a bluish-black or very dark bluish-gray graphitic dolomite marble, already described on page 46. It belongs in the basal dolomite. It takes a good polish.

The beds explored consist, beginning on the west, of 75 feet of bluish-black dolomite, followed by about 250 feet of buff dolomite and then by about 250 feet of bluish dolomite of various shades. The structural relations of these beds are not clear. The eastern and western belts probably belong at the same horizon. The strike is $\mathrm{N} .5^{\circ} \mathrm{W}$. and the dip $60^{\circ} \mathrm{E}$., but this may vary, reducing the figures given for at least the larger thicknesses.

\section{SHANGROW QUARRY.}

The Shangrow quarry, abandoned between 1900 and 1910, is $1 \frac{1}{4}$ miles north-northwest of Proctor station and $1 \frac{1}{2}$ miles N. $15^{\circ} \mathrm{W}$. of the Proctor quarry, in Proctor Township. (See Pl. I.) Owner, Vermont Marble Co., Proctor, Vt.

The marble beds exposed in 1900 consisted, beginning at the top, of 32 feet of banded graphitic marble overlying 14 feet of graphitic quartzose dolomite veined with quartz, under which was an unknown thickness of banded marbles like those above it. The beds belong to the upper graphitic series of the marble formation.

The marble, "mountain dark" (specimens D, XIX, 149, b, c, rough), is a graphitic banded calcite marble of alternating darkgray to black and light bluish-gray bands (beds) ranging from 0.1 to 0.3 inches in width and of uneven and irregular texture, with grain diameter of 0.05 to 0.62 , mostly 0.12 to 0.37 millimeter, and thus of grade 4 (medium); one grain seen measured 0.37 by 2.37 millimeters. In the graphitic bands the calcite grains are generally of smaller diameter, ranging from 0.05 to 0.17 millimeter. The marble contains small quartz particles, small cubes of pyrite, quartz lenses up to 0.37 millimeter in diameter, and in the dark bands abundant graphite. Some bands are muscovitic and pyritiferous. 


\section{PITTSFORD.}

FLORENCE NO. 2 QUARRY.

The Florence No. 2 quarry is 0.9 mile southwest of Fowler station and $1 \frac{1}{4}$ miles nearly west of Pittsford station, in Pittsford Township. (See Pl. I and map of Castleton quadrangle, U. S. Geol. Survey.) The quarry measures 70 feet north to south by 45 feet across, and is 63 feet in depth. In May, 1911, it passed into the hands of the Vermont Marble Co.

The marble beds exposed in the quarry and explored by drilling to a point 170 feet east of it consist of about 210 feet of light and grayish calcite marbles including 8 feet of dark stone. They belong above the intermediate dolomite. (See p. 93.)

The marble, "Florence No. 2" (specimens D, XXXI, 27, a, rough; $\mathrm{b}$, polished), is a calcite marble of very light bluishgray color with whitish and darkgray (graphitic and dolomitic) streaks and spots parallel to the bedding. It is uneven in texture, with grain diameter, in the calcitic parts, of 0.075 to 1 , mostly 0.12 to 0.37 millimeter, and is thus of grade

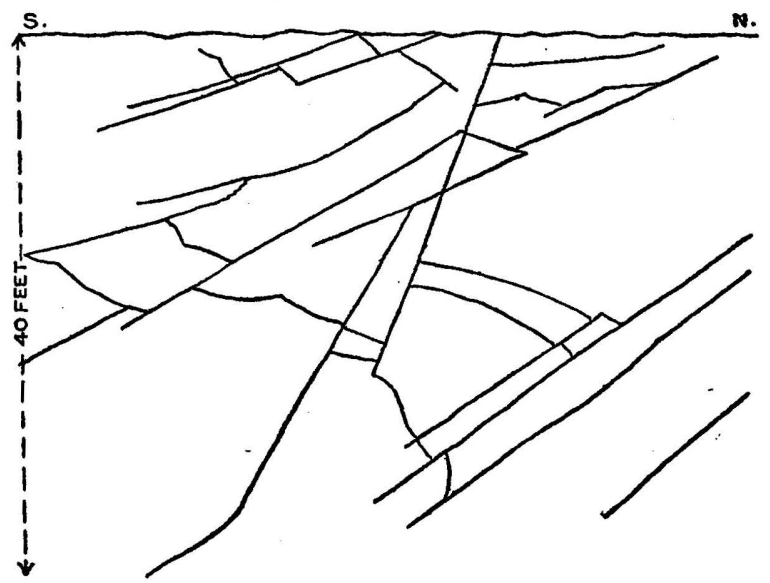

FIGURE 19.-Irregular joints and fractures on west wall of Florence No. 2 quarry, Pittsford.

4. (medium). The very irregular dolomitic lenses, which in thin section are not sharply separated from the calcitic ground, have agrain diameter mostly of 0.05 to 0.25 millimeter and are thus of grade 3 (fine). The dolomite is untwinned and some of the grains have rhombic outlines. Associated with it are a few small quartz grains and muscovite scales. Minute black grains (probably graphite) occur throughout, but more abundantly in the dolomitic lenses, and also a little pyrite. The marble takes a high polish, but the dolomite mottling shows in minute relief on the polished face.

The general structure here is shown in section I, Plate III. The beds strike N. $25^{\circ} \mathrm{W}$. and $\operatorname{dip} 82^{\circ} \mathrm{N} .65^{\circ} \mathrm{E}$. The west wall shows very irregular jointing. (See fig. 19.)

$49311^{\circ}-$ Bull. 521-12-9 


\section{PROSPECT WEST OF FLORENCE NO. 2 QUARRY.}

An east-west trench dug in 1900 across the low ridge immediately west of the site of the Florence No. 2 quarry exposed a handsome white marble interbedded with a coarser one of medium bluish gray banded with black (specimen D, XIX, 202, b), containing a few scales of biotite.

The white $(202$, a) is a calcite marble of milk-white color and of irregular texture, with grain diameter of 0.05 to 0.75 , mostly 0.12 to 0.5 millimeter and of about grade 4 (medium). It contains a few pyrite grains up to 0.03 millimeter, rare grains of quartz, and sparse very minute black particles of uncertain nature.

TURNER QUARRY.

The Turner quarry is less than 1,000 feet northeast of the Florence No. 2 and about three-fourths of a mile southwest of Florence station, in Pittsford Township. (See Pl. I.) The opening, which is of recent date, is about 500 feet north of the Central Vermont Marble Co.'s quarry, which was operated in 1900 but is now disused. It is about 140 feet north to south by 70 feet across and 86 feet deep in one half and 49 feet in the other. It has a tunnel at the south end, 43 feet below the rock surface, 70 feet wide, and extending 35 feet to the south.

In May, 1911, this quarry passed into the hands of the Vermont Marble Co., Proctor, Vt. The marble exposed in the quarry and cropping out on both sides of it consists of the following beds, beginning at the top and west:

Section of marble beds at Turner quarry.

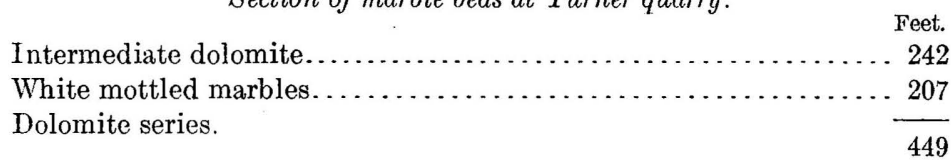

Its position is therefore identical with that of the marble in the Proctor quarry (p. 127).

The marble, "Pittsford Italian" (specimens D, XXXI, 21, c, rough; $f$, polished; a, rough and polished), is a calcite marble of slightly bluish-white color, with finely plicated beds and irregular mottlings of medium gray (graphitic dolomite). One of these little beds is shown in figure 20. They are from half an inch to 3 inches apart. The calcitic part has a grain diameter of 0.05 to 0.87 , mostly 0.12 to 0.37 millimeter, and is thus of grade 4 (medium). The grain diameter of the little dolomite beds and lenses (not crossed by the sections obtained) is probably, like that in the "Pittsford Italian," mostly 0.05 to 0.25 millimeter, and these are thus of grade 3 (fine). The general texture is irregular and uneven. There are very minute 
black particles (graphite?), a few of pyrite, and rare small quartz grains. The marble takes a high polish, but the darker dolomitic passages project in very minute relief on the polished face.

The beds strike N. $25^{\circ}-30^{\circ} \mathrm{W}$. and dip $75^{\circ}$ ENE. The dolomite on the west strikes N. $20^{\circ} \mathrm{W}$. and dips $70^{\circ} \mathrm{N} .70^{\circ} \mathrm{E}$. Both the underlying and overlying dolomite and the intervening marble belong to the east limb of an eastward-inclined syncline, as shown in section I, Plate III. The economic significance of this relation is that eventually, as the quarry deepens, the underlying dolomite will be encountered.

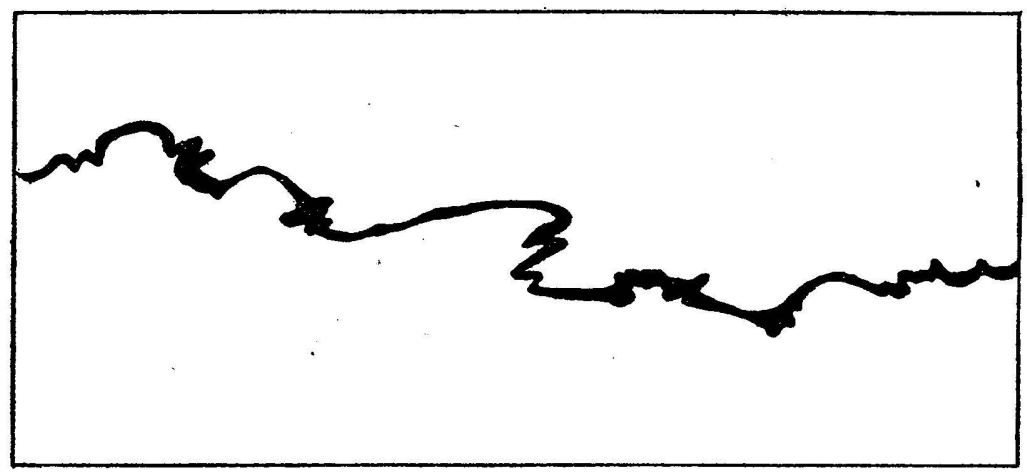

FIGURE 20.-Minute dolomite bed in lower mottled marble, "Pittsford Italian" (specimen D, XXXI, 21,c). Natural scale.

FLORENCE NO. 1 (HOGBACE) QUARRY.

The Florence No. 1 is a new opening, southwest of the now disused "Valley quarry," about three-fourths of a mile west of Florence station, in Pittsford Township. (See Pl. I.). It is 90 feet east to west by 70 feet across. One-half of it is 112 feet deep and the other 70 feet. In May, 1911, the quarry passed into the hands of the Vermont Marble Co., Proctor, Vt.

The marble beds exposed and prospected here, beginning above and on the west, are as follows:

Section of marble beds at Florence No. 1 quarry.

Light mottled marble including a 9-foot bed of darkish gray,

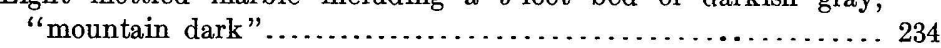

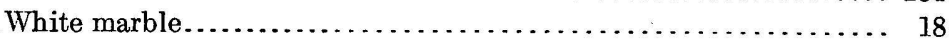

Intermediate dolomite. . . . . . . . . . . . . . . . . . . 254

The position of the beds is thus above the intermediate dolomite and corresponds to that of the beds in the Florence No. 2 quarry. (See p. 92.)

The marble, "Florence No. 1," is a calcite marble of light bluishgray color with fine dark-gray streaks (graphitic and dolomitic beds) parallel to the bedding. On the bed face these dolomite beds appear 
as an irregular mottling. It is practically identical with "Florence No. 2," described on page 129. Its texture is medium (grade 4), but it is regarded as slightly coarser than "Pittsford Italian."

The beds strike N. $25^{\circ} \mathrm{W}$. and dip $70^{\circ}-75^{\circ} \mathrm{ENE}$. The marble and the intermediate dolomite east of it both belong to the east limb of an eastward-inclined syncline. Therefore as the quarry is deepened the underlying intermediate dolomite should eventually be struck, although no indications of dolomite or of any turning of the beds have been found at a depth of 70 feet below the bottom of the quarry. Conspicuous joints dip to the southwest at low angles. Percolating water has by means of its content of carbonic acid formed a series of caves, first along the bedding and then along these joints, as shown in Plate XVII. One of these caves 100 feet below the surface is 10 feet high. These caves occasion much inconvenience in adjusting the cutting machines. An east-west compressive strain has been noticed at this quarry.

\section{FLORENTINE QUARRY.}

The Florentine quarry is at the east foot of the Taconic Range, $1 \frac{1}{2}$ miles N. $72^{\circ} \mathrm{E}$. of Biddie Knob and $1 \frac{1}{4}$ miles west of Florence station, in Pittsford Township. (See Pl. I and map of Castleton quadrangle, U.S. Geol. Survey.) The quarry, a new opening a little west of a disused quarry, measures about 200 feet north to south by 100 feet across and is 100 feet deep in one half and 42 feet in the other. In May, 1911, it passed into the hands of the Vermont Marble Co., Proctor, Vt.

The marble beds exposed and prospected here include 150 feet of graphitic marbles immediately underlying the base of the schist of the Taconic Range and thus belong to the upper graphitic series. In the quarry there is an irregular bed of graphitic untwinned dolomite veined with quartz and white calcite:

The marble, "Florentine blue" (specimens D, XXXI, 24, c, rough; $\mathrm{d}$, polished), is a graphitic calcite marble of dark bluish-gray color, with fine very dark and light gray unplicated bands, and of even, regular texture, with grain diameter of 0.05 to 0.75 , mostly 0.12 to 0.25 millimeter, and thus of grade 3 (fine). It abounds in minute particles of graphite and contains rather plentiful pyrite up to 0.12 millimeter in diameter and rare grains of quartz. This stone takes a very high polish without any protuberances.

The marble strikes N. $25^{\circ} \mathrm{W}$. and dips $60^{\circ} \mathrm{W}$. at the surface of the quarry, turning to $70^{\circ}$ at the bottom. In the disused quarry about 200 feet farther east the dip is at a low angle to the west. At the contact with overlying schist 60 feet west of the quarry the schist is graphitic and has a cleavage foliation striking N. $5^{\circ} \mathrm{W}$. and dipping $20^{\circ}-25^{\circ} \mathrm{E}$. The marble at the contact curves from $90^{\circ}$ to steep west, and the bedding of the schist, obscured by cleavage, is presumably parallel to it. The marble beds belong to the east limb of a syncline. 


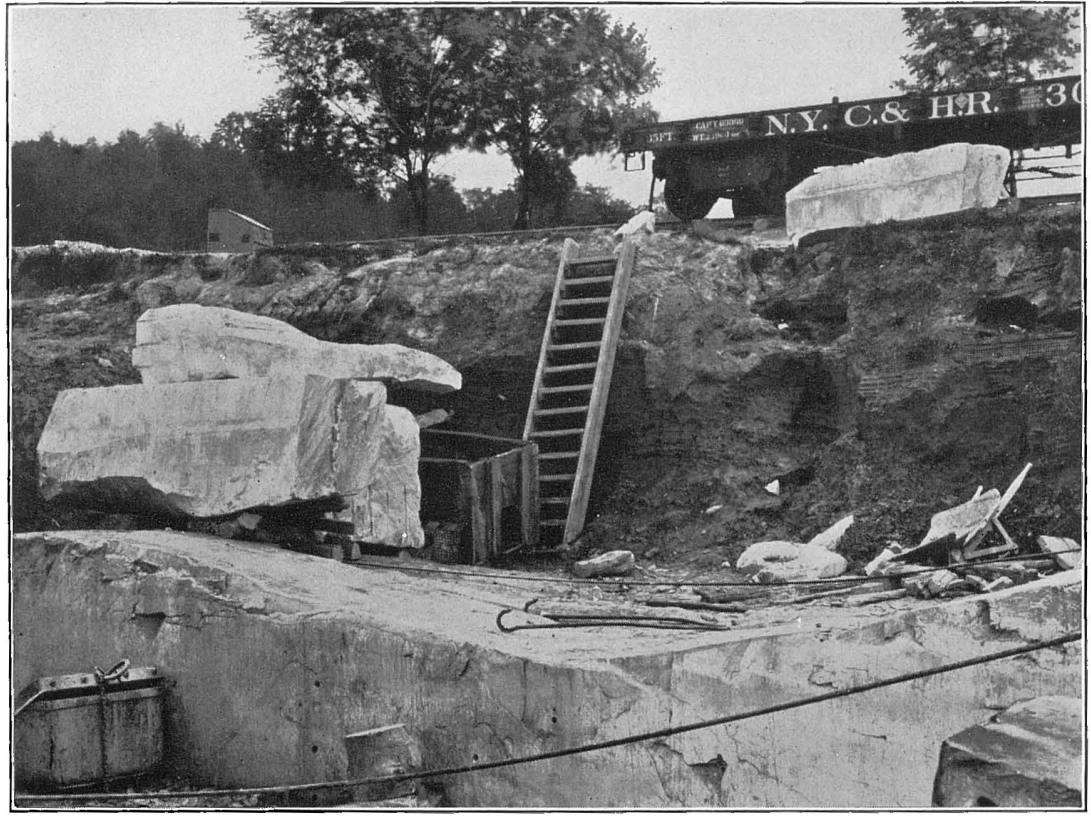

A. GLACIAL FURROW IN WHITE CALCITE MARBLE, PITTSFORD.

The marble is in close erect folds striking N. $20^{\circ} \mathrm{W}$., but the furrow runs S. $20^{\circ} \mathrm{E}$. Thin-bedded clay 20 feet thick, probably deposited by a glacial lake, overlies the marble and has preserved it from weathering, so that good stone occurs at the rock surface.

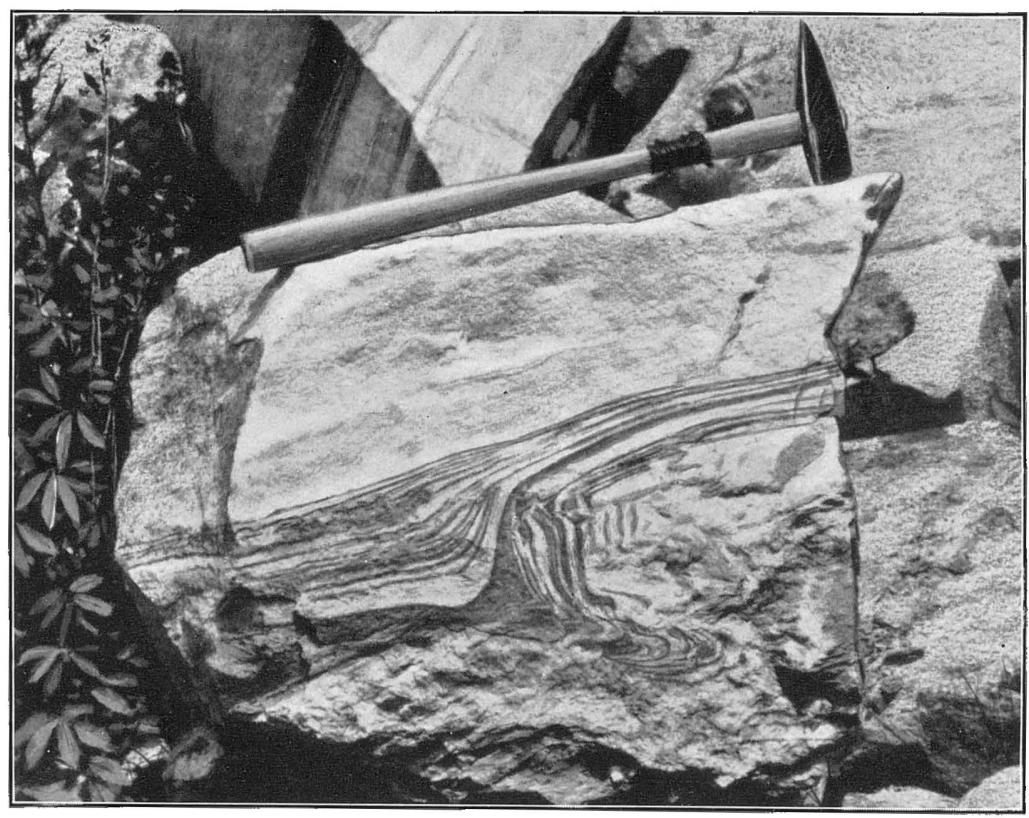

B. PINCHED FOLD OF WHITE CALCITE MARBLE, DUMPS OF OWLS HEAD QUARRIES, SOUTH DORSET.

Showing the prolongation of the apex of the fold by flowage. The bed about and below the fold is dolomite. Hammer 21 inches. 


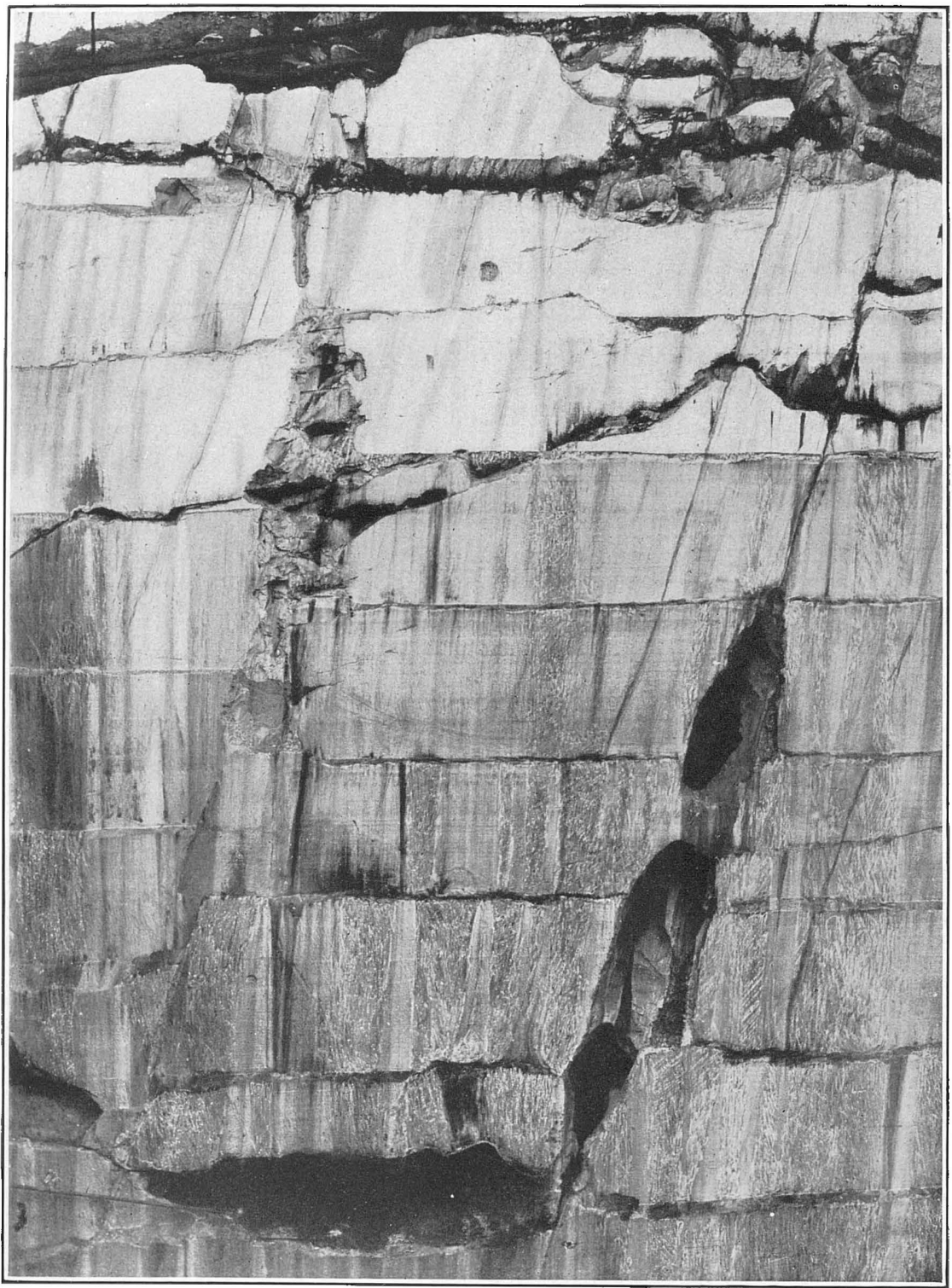

EFFECT OF UNDERGROUND SOLUTION, SOUTH WALL OF FLORENCE NO. 1 QUARRY, PITTSFORD. The lowest cave is 15 feet long. The smaller ones are along a bedding plane. 
Between the quarry and the schist contact the marble beds, recently divested of their protective covering of till, are highly glaciated, as shown in Plate XV, $B$.

\section{HOLIISTER QUARRIES.}

The Hollister quarries are $1 \frac{1}{4}$ miles northwest of Florence station and half a mile west of Florence Cross Roads, in Pittsford Township. (See Pl. I and map of Castleton quadrangle, U. S. Geol. Survey.) The quarries comprise two openings on the same beds-the southern one, the original Hollister quarry, which at the surface measures 150 feet north to south by 25 feet across, but at the bottom, 316 feet down, is 189 by 125 feet, and a new one, 200 feet north, the Valley quarry, which measures 100 feet north to south by 25 feet across at the surface, but 125 feet at the bottom, 85 feet down. From the south end of the original quarry a tunnel, 60 feet wide and 40 feet high, has been drilled 70 feet west.

Operator, Vermont Marble Co., Proctor, Vt.

The marble beds exposed and prospected here, given in more detail on page 91 , comprise, beginning on the west and above:

Section of marble beds at Hollister quarries.

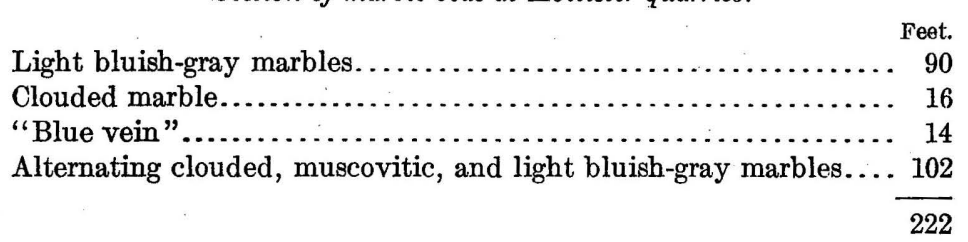

'This set of beds apparently lies a little above the intermediate dolomite. (See p. 93.)

The marble, "Pittsford Valley" (specimens D, XIX, 148, a, rough, from bed A; and D, XXXI, 16, a, polished), is a calcite marble of light bluish-gray color with little medium to dark gray (graphitic and dolomitic) plicated beds which on the bed surface appear as irregular mottling. Its texture is uneven. The grain diameter in the calcitic parts is 0.05 to 0.75 , mostly 0.12 to 0.37 millimeter, and thus of grade 4 (medium). In the dolomitic parts the grain diameter is 0.02 to 0.25 , mostly 0.07 to 0.12 millimeter, and thus of grade 2 (very fine). Minute black particles (probably graphite) occur throughout but are more plentiful in the dolomitic parts, which also contain very little pyrite and muscovite. The marble takes a high polish, but the dolomitic mottling projects in very minute relief.

A specimen of bed K (D, XIX, 148, c, rough) is a calcite marble of light bluish-gray color without mottling and of regular, even texture, with grain diameter of 0.05 to 0.87 , mostly 0.12 to 0.5 millimeter, and thus also of grade 4 (medium) but a trifle coarser than that of bed A. 
(See fig. 21.) The average grain diameter of the calcitic parts, determined by the Rosiwal method, is 0.1484 millimeter.

In general the marbles of these quarries are more bluish than those of the Proctor and Riverside quarries.

The beds strike N. $5^{\circ} \mathrm{W}$. and dip $80^{\circ} \mathrm{E}$. to $90^{\circ}$. Although the beds at a depth of 316 feet are still vertical, they will be found eventually to be underlain by the dolomite, which crops out east of the quarry. The character of the folds here is not clear. There are four sets of joints-set $a$, strike N. $80^{\circ}$ E., vertical, spaced 2 to 5 feet for a distance of 50 feet between the two openings; set $b$, strike east to west, dip $10^{\circ} \mathrm{N}$., few, spaced 3 to 20 feet; set $c$, same strike, dip $55^{\circ} \mathrm{N}$., spaced 3 to 50 feet; set $d$, same strike, dip $10^{\circ}-15^{\circ} \mathrm{S}$. The quarry is at the

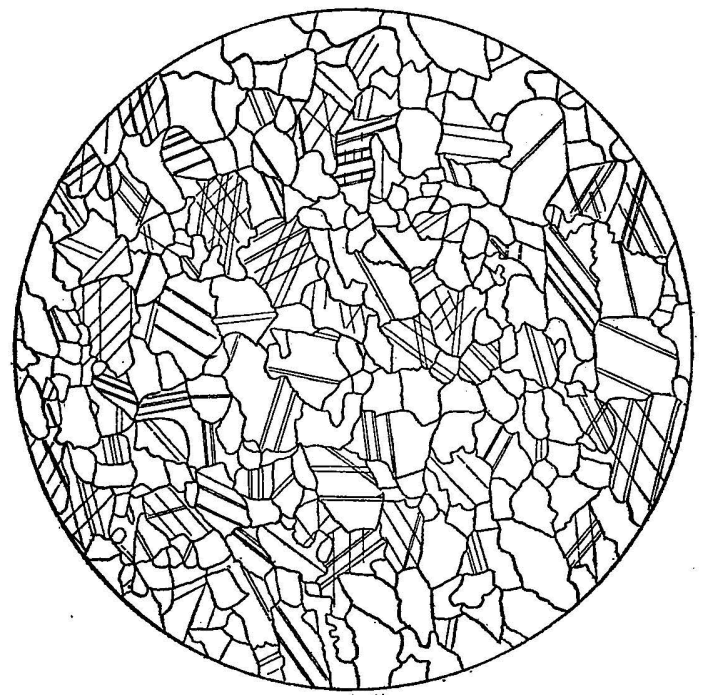

FIGURE 21.-Thin section of coarser part of light-gray clouded calcite marble from bed $\mathrm{K}$, Hollister quarry, Pittsford. Enlarged 20 diameters. east foot of a marble cliff 100 feet high. On the east side of the northern opening the marble at the surface is not over 5 feet thick. In drilling eastward at a depth of 75 feet the marble was found to extend but 25 feet. It is possible that the beds have suffered considerable erosion at this point.

Specimens: Champlain apartment house, Washington, D. C.; fourteen columns 29 feet 9 inches long and from 2 feet 10 inches to 3 feet 4 inches in diameter in Curtis Publishing Co.'s building, Philadelphia. These columns were cut parallel to the bed and show the small grayish plicated dolomitic beds. (See also Pl. VI, B.)

\section{LANDON QUARRY.}

The recently opened old prospect known as the Landon quarry is $1 \frac{1}{2}$ miles $\mathrm{N} .10^{\circ} \mathrm{W}$. from the Hollister quarries and close to the Brandon-Pittsford line, in Pittsford Township. (See Pl. I and map of Brandon quadrangle, U. S. Geol. Survey.) The opening measures 84 feet east to west by 50 feet across and 20 feet in depth.

Operator: Vermont Marble Co., Proctor, Vt.

The marble exposed consists of 80 feet of calcite marble. The upper part of the dolomite series is but a few hundred feet east of the quarry. 
The marble, "Landon" (specimen D, XXXI, 18, a, b, rough), is a calcite marble of slightly bluish white color, with medium to dark gray, intricately plicated dolomitic beds up to 0.1 inch thick, which project slightly on the weathered face (specimen D, XXII, 240, a). Its texture is uneven, with grain diameter in the calcitic parts of 0.05 to 0.75 , exceptionally 1.5 , mostly 0.12 to 0.37 , averaging 0.24 millimeter, and thus of grade 4 (medium), and in the dolomitic parts as much as 0.02 millimeter; but also with large cloudy plates 0.75 to 1.75 millimeters across having rhombic cleavage and rarely dolomitic twinning. These plates show under a 450 enlargement a peculiar granular texture. The marble contains very little quartz, some muscovite, pyrite, limonite, and sparse very minute black particles throughout. Its general texture is a little finer than that of the beds of the Hollister quarry and its little dolomitic beds are more numerous, producing more mottling.

The beds shown by the plications strike N. $20^{\circ}-25^{\circ}$ W. and dip $80^{\circ}$ WSW. A close jointing or cleavage spaced in places 1 inch to 2 feet dips $30^{\circ} \mathrm{E}$. One set of joints strikes N. $30^{\circ} \mathrm{E}$. and a single vertical joint on the north wall runs east to west. The relation of the beds to the two dolomite series is not clear.

\section{BRANDON.}

There were but two active quarries in Brandon in 1910. The marbles of four idle ones which were visited in 1903 were examined microscopically. Two new prospects were opened in 1911.

\section{QUARRY 238.}

The abandoned quarry at locality No. 238 is a mile north of the Landon, a little east of the railroad, and about 2 miles S. $25^{\circ} \mathrm{E}$. of Brandon station. (See Pl. I.)

The marble is a calcite marble of milk-white color, with little cloudy dolomitic and muscovitic beds. The calcitic parts are irregular in texture and have a grain diameter of 0.05 to 0.75 , mostly 0.12 to 0.38 millimeter, being thus of grade 4 (medium). The marble contains some pyrite and a little quartz.

The plicated bedding is vertical and is crossed by low eastwarddipping cleavage ("reeds").

\section{BRANDON ITALIAN QUARRY.}

The Brandon Italian quarry is half a mile south of Brandon station and 0.7 mile west of the west boundary of the basal dolomite. (See Pl. I and map of Brandon quadrangle, U. S. Geol. Survey.) The quarry measures about 600 feet north to south by 60 feet across and 75 feet in depth.

Operator since 1909, Vermont Marble Co., Proctor, Vt. 
The marble is of uncertain thickness owing to close folding, as explained below. The character of the marble is regarded by the

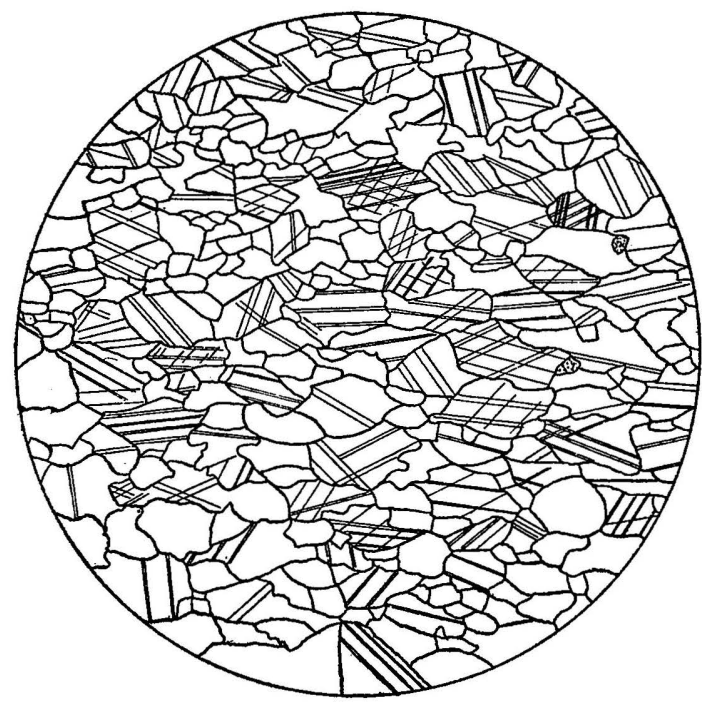

FIGURE 22.-Thin section of calcitic part of clouded calcite marble from the Brandon Italian quarry, showing irregular grain form and elongate texture. Dotted particles are quartz. Enlarged 20 diameters. operators as identical with that of the Hollister quarries.

The marble, "Brandon Italian" (specimens $\mathrm{D}, \mathrm{XXII}, 250, \mathrm{a}, \mathrm{b}$, rough) is a calcite marble of light bluish-gray color crossed by small dark-gray graphitic dolomitic beds which on the bed face produce an irregular mottling. Its texture is uneven and somewhat elongated, with grain diameter in the calcitic parts of 0.05 to 0.87 , mostly 0.17 to 0.5 millimeter, and it is thus of grade 4 (medium). The grain form

and texture are shown in figure 22. An estimate of the average grain diameter by the Rosiwal method yields 0.155 millimeter. The section did not cross any of the dolomitic beds. Quartz grains, somewhat plentiful, measure 0.05 to 0.07 millimeter. A little pyrite and rarely muscovite are also present.

The beds strike N. $20^{\circ}-25^{\circ} \mathrm{W}$. and on the east side dip steeply to the east at the south end but stand vertical at the north end. In the center of the quarry they zigzag in a horizontal direction, indicating a synclinal or anticlinal structure. A repetition of the beds on either side of the synclinal axis is therefore to be expected. Core drilling at a point 200 feet

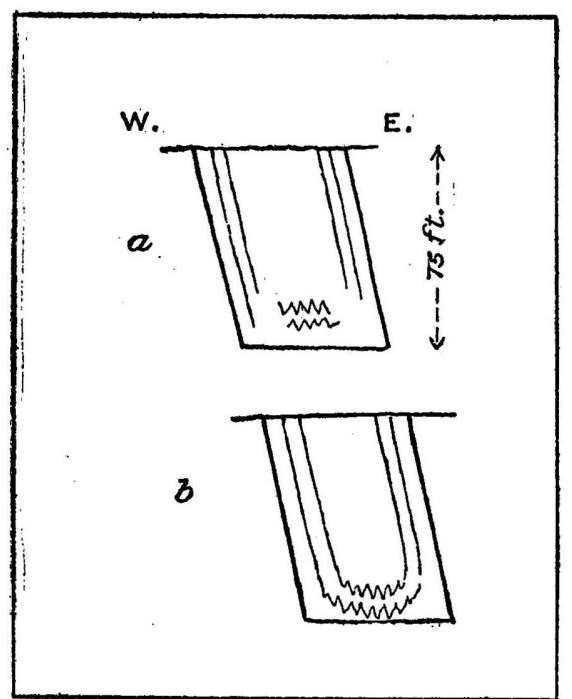

Figure 23.-Structure at Brandon Italian quarry. $a$, Actual; $b$, an interpretation.

east of the quarry shows continuous marble. In breaking the blocks an obscure vertical cleavage parallel to the bedding on the 
east side of the quarry is utilized. The possible synclinal structure is shown in figure $23, b$. The marble in 1903 was reported as affording evidence of compressive strain.

Specimen: Roman Catholic Church at Middlebury.

BRANDON ITALIAN HIGH STREET QUARRY.

The Brandon Italian High Street quarry is 0.6 mile northeast of the Brandon Italian quarry and half a mile east-southeast of Brandon station. (See Pl. I.)

Operator since 1909, Vermont Marble Co., Proctor, Vt.

The marble beds consist of 107 feet of light bluish-gray marbles situated very near the underlying dolomite. The marble closely resembles that of the Brandon Italian quarry.

The marble beds strike about north and dip $50^{\circ} \mathrm{W}$. The knoll east of the quarry consists of the bluish-gray basal dolomite, striking $\mathrm{N} .25^{\circ} \mathrm{W}$. and dipping $90^{\circ}$. The first dolomite west of the quarry should be the intermediate dolomite.

GOODELI QUARRY.

The Goodell quarry is at the foot of the north end of the Taconic Range about $2 \frac{1}{2}$ miles southwest of Brandon station. (See Pl. I.) It is a small opening abandoned soon after it was made owing to the smallness of the marble bed.

The beds include 15 feet of fine white marble, apparently both underlain and overlain by a dark gray graphitic quartzose dolomite. Some of the marble is in thin beds and the whole was reported as running out or covered along the strike. It probably belongs toward the upper graphitic series.

The marble (specimen N. D, I, 9, b) is a calcite marble of milkwhite color and of regular, even texture, with grain diameter of 0.02 to 0.37 , mostly 0.07 to 0.25 millimeter, and thus of grade 2 (very fine). It takes a high polish.

The marble bed and the dolomitic rock on both sides of it strike N. $30^{\circ}$ E. and $\operatorname{dip} 35^{\circ} \mathrm{S} .60^{\circ} \mathrm{E}$. Of the overlying dolomite a thickness of 15 feet is exposed. It is uncertain whether the two dolomitic beds are one bed doubled over or two distinct beds. The rock in thin section has a grain diameter of 0.009 to 0.094 , mostly 0.02 to 0.04 millimeter. Its character as dolomite is not shown by twinning. It contains sparse grains of quartz and rarely one of plagioclase (feldspar). A very graphitic and quartzose bed a millimeter thick and another of twinned calcite particles with quartz grains appear in the section.

W. T. Schaller, of the Geological Survey, who examined the rock qualitatively, reports that "calcite and dolomite together form a 
large part of it, but dolomite itself does not form the chief constituent."

A railing with balusters of this marble can be seen at the side of the pulpit in the Congregational Church at Brandon.

CONNELI QUARRY.

The Connell quarry is about 1,800 feet ENE. of the Goodell quarry and $4 \frac{1}{4}$ miles southwest of the bench mark in Brandon village. (See Pl. I.) Operator, Brandon Marble Co., Brandon, Vt.

The quarry measures 60 by 30 feet and is 24 feet deep; there is a second opening 175 feet to the north.

The beds here consist of 30 feet of marble, both overlain and underlain by graphitic dolomite. The stratigraphic position is like that of the Goodell quarry. The thickness of 30 feet includes a 7-foot bed of fine white statuary, 13 feet of mottled, and 10 feet of gray marble.

The white marble (specimens D, XXXI, 88, a, rough; b, polished) is a calcite marble of very faint ivory tint and of regular, even texture, with grain diameter of 0.05 to 0.45 , mostly 0.1 to 0.24 millimeter. A Rosiwal measurement of a thin section shows an average grain diameter of 0.1 millimeter. It therefore belongs to grade 2 (very fine), as does also the "statuary Rutland." It contains rare quartz grains and sparse minute black specks. It takes a high polish.

The beds are on the strike of the beds in the Goodell quarry (N. $30^{\circ}$ E.) and $\operatorname{dip} 40^{\circ} \mathrm{S} .60^{\circ}$ E. The excavations have not proceeded far enough to show the relations of the two dolomite beds to one another.

ROYCE QUARRY.

The long idle Royce quarry is three-fourths of a mile northwest of Brandon station at the west foot of a ridge 100 feet high. (See Pl. I.) The quarry measures about 150 feet along the strike. The marble exposed measures about 70 feet, underlying (really overlying in consequence of overturned folds) grayish dolomite which may be the intermediate dolomite.

The marble is of two kinds. One (specimen D, XXII, 218, a) is a calcite marble of very light bluish-gray color, with inconspicuous medium-gray dolomitic (?) mottling (beds), and of even texture, with grain diameter in the calcitic part of 0.02 to 0.37 , mostly 0.1 to 0.25 millimeter, and thus of grade 3 (fine). It contains some small quartz grains and some pyrite. There is a rough parallelism of the twinning planes of different particles. The other (specimen D, XXII, 218, b) is a calcite marble of milk-white color, with little grayish micaceous dolomitic beds. The calcitic part has a grain diameter of 0.02 to 0.5 , mostly 0.1 to 0.25 millimeter, and is thus also of grade 3 . It contains small sparse quartz grains and very minute black particles of uncertain nature. 
The marble and the dolomite east of it strike $\mathrm{N} .15^{\circ}-20^{\circ} \mathrm{W}$. and dip steeply to the east. The upper marble beds are crossed by joints dipping $30^{\circ} \mathrm{W}$.

\section{PROSPECT 255.}

Prospect 255 is $2 \frac{1}{4}$ miles north of Brandon station, just west of the boundary of the basal dolomite east of the road to Leicester. (See Pl. I.)

The marble is white and light bluish gray. A specimen of the latter (D, XXII, 255, a) shows small medium gray dolomitic bands up to 0.1 inch wide. The calcitic part is of irregular texture and has a grain diameter of 0.05 to 0.75 , mostly 0.12 to 0.5 millimeter, being thus of about grade 4 (medium). It contains minute quartz grains and some pyrite. A large plate of untwinned dolomite, 1.12 millimeters across, with rhombic cleavage, is crowded with graphite. This marble is coarser than that of the Royce quarry.

The beds strike N. $10^{\circ} \mathrm{E}$. and dip $35^{\circ} \mathrm{E}$. Dolomite lies east of the marble with like dip, both forming part of an overturned fold. The marble thus belongs at base of the marble series.

VERMONT ITALIAN MARBLE CO.'S QUARRY.

The quarry of the Vermont Italian Marble Co., of Brandon, is $1 \frac{1}{2}$ miles N. $20^{\circ} \mathrm{W}$. of the bench mark in Brandon village. (See Pl. I.) It was opened in 1911.

The marble is reported as practically identical with that of the Brandon Italian quarry, 2 miles to the south, and is said to measure 600 feet in width, without reference, of course, to any duplication in folding. The beds dip about $18^{\circ}$ roughly eastward. One or more of them attain a thickness of 8 feet.

SUDBURY.

SUDBURY BRECCIA PROSPECT.

A reddish hematitic dolomite resembling some of the fragments in the breccia of the Dyer quarry, in Manchester (p. 97), occurs at a point 4 miles WSW. of Brandon, in Sudbury Township, along a brook flowing north into Otter Creek. It is about half a mile northwest of the site of the Cool farmhouse.

The bed from its location appears to be very near the top of the marble. The rock is brecciated in places and coarsely cemented with flesh-colored and colorless calcite.

\section{MIDDLEBURY.}

MIDDLEBURY MARBLE CO.'S QUARRY.

The abandoned quarry of the Middlebury Marble Co. is 2 miles eastsoutheast of Middlebury, a little west of the west limit of the basal dolomite and about 1,100 feet east of the road to East Middlebury, 
in Middlebury Township. (See map of Middlebury quadrangle, U. S. Geol. Survey.) This quarry has been idle for over 28 years. It measures about 100 feet east to west.

The following section is exposed, beginning on the west:

Section of marble beds at Middlebury Marble Co.'s quarry.

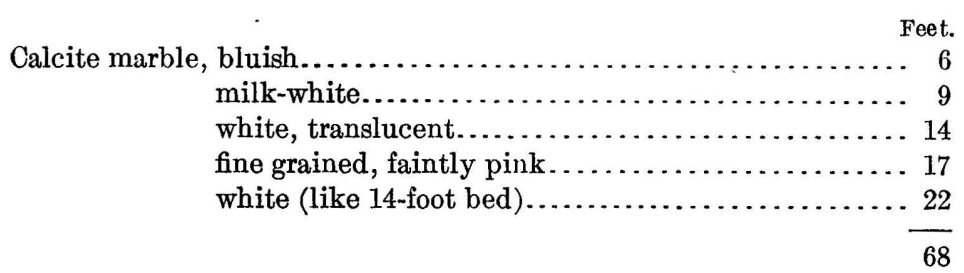

The marble of the 9-foot bed (specimens D, XXII, 410, a and c, from a prospect 250 feet farther south) is a calcite marble of milk-white

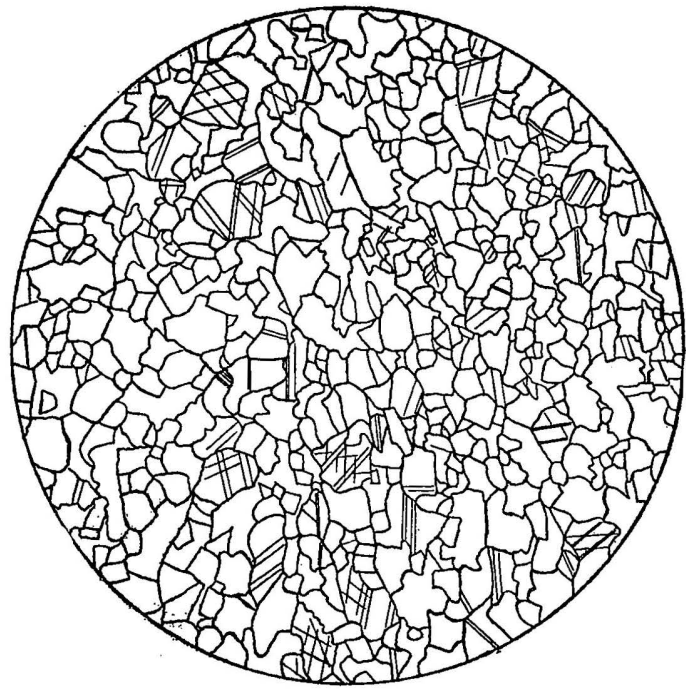

Figure 24.-Thin section of white calcite marble from abandoned quarry of Middlebury Marble Co. Enlarged 20 diameters. color and of regular texture, with grain diameter of 0.02 to 0.37 , mostly 0.12 to 0.25 millimeter, and thus of grade 3 (fine). It contains rare quartz grains and spherules of pyrite. The texture of this rock is that of a normal marble and very different both in grade and in grain arrangement from the section obtained of Brandon Italian, as will be noticed by comparing figures 24 and 22 . An estimate by the Rosiwal method shows its average grain diameter to be 0.11 millimeter.

The structural relations are not clear. The marble, however, probably belongs not far from either the dolomite series or the intermediate dolomite. The dip on the west side of the quarry is $40^{\circ}-$ $50^{\circ} \mathrm{W}$. About 600 feet east of the quarry a whitish dolomite and very quartzose beds strike N. $10^{\circ} \mathrm{W}$. and dip about $72^{\circ} \mathrm{E}$. At an old disused quarry a mile north marble about 40 feet thick strikes north and dips $45^{\circ} \mathrm{E}$.; and at another opening a quarter of a mile west of 'this one white marble about 70 feet thick, with muscovitic streaks, strikes N. $10^{\circ}$ E. and dips $90^{\circ}$. 


\section{MARBLE LEDGE QUARRY.}

The long disused Marble Ledge quarry is about $3 \frac{1}{4}$ miles N. $25^{\circ} \mathrm{E}$. of Middlebury and $1 \frac{3}{4}$ miles east of Beldens. (See map of Middlebury quadrangle, U. S. Geol. Survey.)

A body of white marble about 60 feet thick is exposed, striking north and dipping $50^{\circ} \mathrm{E}$. Muddy Branch here flows through a small gorge along the strike and there seems to be a syncline between the stream and the quarry.

\section{MONKTON AND BRISTOL.}

The dolomite of Monkton has been described on page 45. It belongs apparently to the dolomite which underlies the calcite marbles. The only quarry operated in recent years was idle in 1910.

VERMONT MARBLE CO.'S MONKTON QUARRY.

The Monkton quarry of the Vermont Marble Co. is at the west foot of the so-called Hogback Mountains, really the west flank of the Green Mountain range, about $1 \frac{1}{2}$ miles north-northeast of East Monkton and 6 miles N. $10^{\circ} \mathrm{W}$. of Bristol, in Monkton Township, Addison County. (See map of Middlebury quadrangle, U. S. Geol. Survey.) The opening is 30 by 15 feet and 5 feet deep. The quarry is not now used, the company having withdrawn the marble from the market.

The beds exposed consist of about 270 feet of dolomite. The marble, "Ruvaro" (specimens D, XXXI, 63, a fresh; d, weathered), is a mottled pink and white quartzose hematitic dolomite marble. It contains thin beds of sericite and quartz (specimens D, XXXI, 63, $\mathrm{b}, \mathrm{c})$. Descriptions of these will be found on page 45 .

The dolomite strikes N. $25^{\circ}-30^{\circ}$ W., dips $30^{\circ}-40^{\circ}$ W., and is crossed by slip cleavage dipping $40^{\circ} \mathrm{E}$. and in places by close eastwest joints dipping steeply to the north. About 315 feet east of the dolomite is an outcrop of quartzite, slightly calcareous in places, striking $\mathrm{N} .15^{\circ} \mathrm{W}$. and dipping at a steep angle to the west, crossed by cleavage dipping $60^{\circ} \mathrm{E}$. A little farther south, at the head of a brook flowing southward, dolomite and quartzite are in contact, both rocks for the depth of a foot dipping steeply to the east, whether by faulting or minor overturned folding is not evident.

This marble was polished by the company and sold for decorative use.

COLUMBIAN MARBLE CO.'S MONKTON QUARRY.

The Monkton quarry of the Columbian Marble Co. is 0.6 mile S. $32^{\circ} \mathrm{W}$. of the Vermont Marble Co.'s quarry, on the south side of the east-west crossroads in the same township. The opening is about 20 feet square and 5 to 10 feet deep and has been long disused. 
The marble is identical with that of the Vermont Marble Co.'s quarry. The weathered parts have a muddy gray color. The beds strike north, dip $45^{\circ} \mathrm{E}$., and show many minor fractures along the bedding.

CHAPIN PROSPECT.

The same dolomite marbles crop out between the two quarries last described, on the farm of L. O. Chapin, of Bristol, Vt.

\section{JIMMO PROSPECT.}

The Jimmo prospect is in Bristol Township $1 \frac{1}{4}$ miles west-southwest of the Bristol bench mark. (See map of Middlebury quadrangle, U. S. Geol. Survey.) Owner, Harry Jimmo, Bristol, Vt.

The marble (specimen D, XXXI, 67, a) is a quartzose hematitic dolomite marble of deep-pink color, differing from that of the Monkton quarries and prospects by its less conspicuous mottling and deeper shade. It also has films of sericite. The thickness exposed is 8 feet.

\section{SWANTON.}

The dolomite marbles of Swanton have already been described in a general way on page 43 . The quarries, opened about 1870, are about a mile S. $65^{\circ} \mathrm{E}$. from Swanton, on a ridge on the south bank of Missisquoi River and rising to 165 feet above it, in Franklin County. Five openings situated at different elevations and on different beds are now in occasional use. They have working faces on the east ranging from 15 to 40 feet in height and from 50 to 100 feet or more in length. Operator, Barney Marble Co., Swanton, Vt.

The marble beds are about 150 feet thick. The character of the beds is shown in the descriptive sections given below. Some of the beds are uniformly reddish brown and recur at irregular intervals. Others, near the top, are uniformly bluish gray. Some at the base are greenish gray, with brecciated dolomitic lenses or beds and distorted corals. Others have a reddish or purplish matrix with similar brecciated beds and corals.

The marbles are known commercially as "Champlain marbles." There are five more marked varieties described in the following paragraphs.

"Royal red" (specimens D, XXXI, 3, a, polished; e, rough with chloritic veinlets) is a quartzose hematitic untwinned dolomite marble of dark reddish-brown color, with irregular, slightly lighter clouds and some whitish streaks. It consists, in descending order of abundance, of $(a)$ dolomite plates of irregular form, tending to rhombic outline, and of some rhombs with grain diameter of 0.02 to 0.3 , mostly 0.02 to 0.12 millimeter, averaging 0.07 and thus of grade 1 (extra fine); (b) interstitial reddish-brown hematitic (kaolin), in 
places more abundant, forming streaks along the bedding; (c) plentiful angular quartz grains, 0.02 to 0.15 but mostly under 0.07 millimeter with rare grains of feldspar (plagioclase); $(d)$ a few opaque particles (magnetite?); and (e) rare muscovite flakes. The dolomite plates have very minute reddish specks. The quartz grains have cavities with moving vacuoles. This marble is very sonorous, emits an argillaceous odor, effervesces very slightly with acid test, and takes a high polish. A thin section of it is shown in figure 8, page 44 .

"Jasper" (specimens D, XXXI, 3, g, rough; and c, polished) is a quartzose hematitic untwinned dolomite marble of bright-reddish ground containing pinkish and white irregular lenticular objects from 0.1 to 0.7 inch in width and from an inch or less to 8 inches in length, generally with the long axis parallel to bedding but in places at all angles. The white ones are highly crystalline and effervesce as little as does the ground under acid test, and some have a nucleus of milky quartz. The ground has the same composition as the "royal red" but contains magnetite grains, giving rise to hematite stain. The corals are in part coarsely crystalline twinned dolomite and in part granular dolomite. In sonorousness, effervescence, and polish this marble is like the "royal red." A photograph of a specimen of this marble is reproduced in Plate VIII, $A, c$, and blocks of it are shown in Plate V, $B$.

"Lyonnaise" (specimen D, XXXI, 3, b, polished) is a quartzose hematitic untwinned dolomite marble of brownish-red ground or of merging forms of roundish cylindrical or irregular outline in brownish red with the interspaces filled with whitish crystalline dolomite. One of these forms has crystalline quartz in the center. The ground is of the same composition and texture as the "royal red." Some of the white twinned dolomite incloses granular dolomite. In sonorousness and effervescence of ground this marble is like the "jasper" and the "royal red." The polished face shows some dull (kaolinic?) streaks.

"Oriental" (specimens D, XXXI, $3, \mathrm{~h}$, rough; $\mathrm{d}$, polished) is a quartzose hematitic and magnetitic untwinned dolomite marble with ground of dark reddish brown inclosing dark purplish-gray areas of very irregular curving outline and concentrically banded, also with some irregular spots of white calcite having a nucleus of crystalline quartz. The ground is like that of "royal red" in texture and composition. The dark purplish-gray parts abound in magnetite grains, more or less oxidized to hematite, and contain rare minute scales of biotite. The coarsely crystalline white parts appear to be part calcite and part dolomite. There are veinlets of white twinned dolomite. The sonorousness, effervescence of ground, and polish of this marble are like those of "royal red."

"Olive" (specimens D, XXXI, 3, k, l, rough; and $\mathrm{m}$, polished) is a quartzose untwinned dolomite marble of light, faintly greenish-gray 
ground, inclosing very irregular lenses or elongated cones, more or less parallel, some of them brecciated, of light pinkish-gray color. Some of these lenses have a nucleus of white twinned dolomite surrounding crystalline quartz; most of them have a dark-brownish rim of limonite from the oxidation of pyrite. The dolomite plates of the ground carry minute dark grains. The ground also contains pyrite and grains of magnetite, mostly not oxidized to hematite. There are rare muscovite scales in the finer parts. This marble is also very sonorous, emits an argillaceous odor, and effervesces very slightly with acid test. The polish is fair but shows some dull (kaolinic?) streaks.

The dolomite marble beds of Swanton are underlain on the west by a calcareous bed containing the brachiopod Kutorgina, of Lower Cambrian age, and are overlain on the east by the Lower Cambrian shales of St. Albans. ${ }^{1}$ The following sections were taken at the quarries:

1. At the top of the hill, strike N. $30^{\circ}$ E., dip $10^{\circ}$ S. $60^{\circ}$ E.: Beginning at the top, 17 feet of mottled red and white dolomite marble, 3 feet of bluish-gray dolomite, 2 feet of plain red ("royal red"), 16 feet of mottled red and white. A joint face is coated with salmoncolored calcite. The bluish-gray dolomite (specimen D, XXXI, 3, i) has a marked argillaceous odor and weathers light ocher color; its effervescence is slight. In thin section this is a quartzose untwinned dolomite with a few grains of magnetite, passing into hematite, and some light-yellow grains, probably from oxidized pyrite. Interspersed among the quartz grains are a few of feldspar (orthoclase and microcline).

2. At the next quarry down: 12 feet of mixed dolomite beds, overlying 7 feet of hematitic and magnetitic dolomites with purplish spots ("oriental"). Some joints strike N. $35^{\circ}$ E., stand vertical, and are spaced 5 to 18 feet; others strike N. $50^{\circ}$ W., are vertical to steep, and are spaced 5 to 20 feet. Some diagonal fractures are coated with chlorite and salmon-colored calcite.

3. At a disused quarry next below: Beginning at the top, 8 feet of alternating mixed dolomite marbles, 2 feet of plain red ("royal'), 8 to 10 feet with white lenses or corals, discolored, and 2 to 3 feet plain red ("royal"). On some of the weathered surfaces the red argillaceous hematitic cement projects above the white lenses. The brecciation of the lenses is distinct.

4. Below the disused quarry and near the gateway, strike N. $50^{\circ}$ E., dip $10^{\circ}-15^{\circ} \mathrm{S} .40^{\circ} \mathrm{E}$.: Beginning at the top, 10 feet of hematitic dolomite with light lenses and corals, rather short and mostly

1 See Hitchcock, Edward, and Hager, A. D., Geology of Vermont, vol. 2, 1861, pp. 773-775. Edson, G.E., Geology of the town of Swanton: Sixth Rept. Vermont State Geologist for 1907, 1908, pp. 210-220, fig. 5. Perkins, G. H., Preliminary report on the geology of Chittenden County: Idem, pp. 224-245, Pl. XXXIX (a slab of marble from Swanton with a number of pteropods, Salterella pulchella). 
parallel to bed, 3 feet of plain red ("royal," measuring 5 to 6 feet at a disused opening a little east), and 10 feet of hematitic dolomite ("jasper"), with long, narrow white corals on bright-reddish ground, the corals at all angles, some vertical, but in places mostly parallel to bed. Joints strike N. $60^{\circ}$ W., dip $70^{\circ}$ N. $30^{\circ}$ E. to $90^{\circ}$, and are spaced 6 to 10 feet. Joints in the "royal" bed strike N. $30^{\circ}-35^{\circ} \mathrm{W}$. and $\operatorname{dip} 25^{\circ}-30^{\circ}$ E. or W.; some are coated with chlorite.

5. At the west foot of the hill near the river and 60 feet above it, lower than section 4 , the following series dips $15^{\circ}$ about southeast, beginning at the top: Uncertain thickness of hematitic dolomite with white lenses, etc., 1 foot of plain red rock, 5 feet like upper bed, and 14 feet of finely laminated grayish dolomite with lenses and corals ("olive").

The marbles of Swanton are used for columns, wainscoting, and tiling. Their attractive and unusual coloring makes them as desirable for interior decoration as does their hardness for floor wear. This hardness is due to their dolomitic and quartzose composition and to their texture. Specimens: Columns and wainscoting in Detroit post office; columns and panels of "royal red" in numismatic room, United States Mint, Philadelphia; wainscoting and counter, Southern California Savings Bank, Los Angeles; wainscoting in Auditorium, Chicago; "olive" wainscoting in Columbus Despatch Building, Columbus, Ohio ; tiling in city hall, Indianapolis, Ind. The length of columns is limited by the joint spacing to 10 feet.

\section{ISLE LA MOTTE.}

FISK QUARRY.

The Fisk quarry, first opened (for lime burning) in 1664 and furnishing building stone in 1788 , is on the west side of the south end of Isle la Motte, in Lake Champlain, $11 \frac{1}{2}$ miles south of the Canada line, in Grand Isle County. The western edge of the quarry is only 100 feet from the shore. The quarry covers several acres and has a depth of 20 feet. Operator, N. W. Fisk, Fisk, Vt.

The series consists in natural order of the following beds which are of Chazy age:

\section{Section of marble beds at Fisk quarry.}

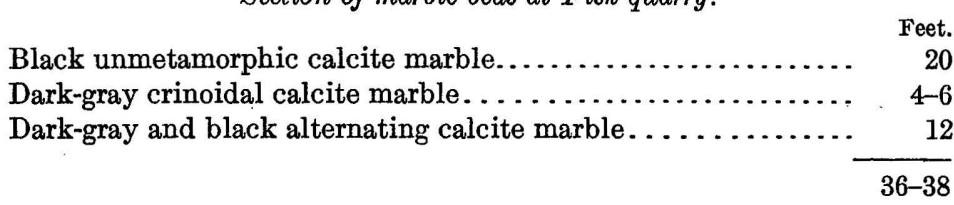

The marbles, "Fisk black" and "Fisk gray" (specimens D, XXXI, 1, a, black, fresh; g, polished; e, f, weathered; b, gray, crinoidal; d, $49311^{\circ}-$ Bull. $521-12-10$ 
gray with Maclurea), have already been described in detail on pages 47-48. (See also fig. 9.) They are slightly dolomitic carbonaceous fossiliferous calcite marbles of unmetamorphic origin and of very dark gray shade and are susceptible of high polish. The weathered surface of the black is dark bluish gray in places, with irregular brownish-gray dolomitic bands. The polished surface is almost black, with here and there sections of Maclureas in white calcite. The stone, except the dolomite bands, effervesces freely with acid and is very sonorous. Certain tests and analyses of these marbles made for the architect of the Bennington Monument and the Buffalo Pan-American Exposition, are in Mr. Fisk's possession.

The beds dip $5^{\circ}$ to $7^{\circ} \mathrm{NE}$. and had a glaciated surface in places, with polished grooves protected by 2 to 4 feet of sand and clay, carrying a few bowlders. ${ }^{1}$ The black beds are subdivided into beds half an inch to 2 inches thick by dolomitic films or bands as thick as half an inch.

The polished product is supplied to the market by the Barney Marble Co., of Swanton. The black has long been used for tiling all over the United States. In the post office at Worcester, Mass., it has been combined with marble from Swanton in wainscoting. The waste of the quarry is sold as crushed stone.

\section{ITME MARBLES.}

\section{IRA AND LEICESTER.}

The lime marbles of Ira and Leicester are included here because of their geologic and petrographic relation to the constructional and monumental marbles already described.

\section{DAT QUARRY.}

The Day quarry is $3 \frac{1}{4}$ miles south-southwest of West Rutland, $1 \frac{1}{4}$ miles southeast of the top of Mount Herrick, in the Taconic Range, on the 1,300-foot level, in the town of Ira, Rutland County. (See Pl. I and map of Castleton quadrangle, U. S. Geol. Survey.) The quarry is reported as having been in operation in Revolutionary times. Operator in 1900, D. D. Day, of Ira, Vt.

The marble belongs either to the upper graphitic beds close to the base of the schist formation, or else within the schist.

The marble is a graphitic calcite marble with fine black and grayish bands, and of very uneven texture, with grain diameter of 0.02 to 0.37 , rarely 2 , mostly 0.07 to 0.25 millimeter, and thus of grade 3 (fine). It contains some quartz and feldspar grains, pyrite, and

\footnotetext{
1 See Sixth Rept, Vermont State Geologist for 1907, 1908, Pl, VI, for photograph of one of the glacial grooves,
} 
much graphite in bands. In places it abounds in sections of a large gastropod, resembling Maclurea. ${ }^{1}$

The marble area is about 300 feet east to west by 800 feet northeast to southwest, and is surrounded by the Berkshire schist of the range. It either protrudes through the overlying schist in consequence of erosion, or else forms a lens within it. On the west side of the quarry a tongue of graphitic sericite schist is dovetailed in the marble and the strike of the marble appears to be nearly east to west and the dip $10^{\circ}-20^{\circ} \mathrm{S}$. The strike of the schist mass east of the marble, however, is N. $30^{\circ} \mathrm{E}$. and the $\operatorname{dip} 20^{\circ} \mathrm{N} .60^{\circ} \mathrm{W}$.; west of the marble the schist strikes east and west and dips at a low angle to the north. The marble seems to occur at the intersection of a minor transverse fold with the usual folds of the Taconic Range. A synclinal axis passes between the quarry and the top of Mount Herrick. The schist next the marble is slickensided, the grooves running $\mathrm{N}$. $5^{\circ} \mathrm{W}$. and dipping $45^{\circ} \mathrm{E}$. The marble is much jointed, fractured, and veined with calcite and quartz. Vertical joints strike N. $20^{\circ} \mathrm{E}$. and are coated with felty asbestos, "mountain leather" (specimen $\mathrm{D}, \mathrm{XIX}, 259$, e), indicating metamorphism subsequent to jointing.

HUNTLEY QUARRY.

The Huntley quarry is about 800 feet west of Leicester Junction, $5 \frac{1}{4}$ miles northwest of Brandon station, in Leicester Township, Addison County. (See Pl. I and map of Brandon quadrangle, U. S. Geol. Survey.) Operator, Brandon Lime \& Marble Co., Leicester Junction, Vt.

The stratigraphic position of the marble beds of this quarry can hardly be determined, owing to the scarcity of outcrops and the distance of the quarry from the basal dolomite on the east and the schist on the west, 2 miles in each case. Marble more than 20 feet thick is exposed in beds which are doubled over on themselves two or three times.

The marble (specimen D, XX, 217, a) is of translucent but dull aspect, light buff-pinkish color, and uneven parallel elongate texture, as shown in figure 25, with alternate irregular tiers of large and small grains. The larger grains, whose longer axes are parallel, have a diameter of 0.04 to 0.2 , mostly 0.04 to 0.09 millimeter, and are thus of grade 1 (extra fine); the smaller grains are more roundish, with a tendency to rhombic form, and have a grain diameter of 0.009 to 0.03 , averaging possibly about 0.02 millimeter, finer than grade 1. The larger grains show rhombic cleavage and twinning

1 This locality is referred to by Hitcheock and Hager (Geology of Vermont, vol. 1, 1861, p. 432), also by Wing (Dana, J. D., Am. Jour. Sci., 3d ser., vol. 13, 1877, p. 339). In February, 1901, Dr. C. D. Walcott expressed the opinion in a letter to the writer that there was no reason why the fossils of this locality, which resemble those occurring more or less abundantly to the north in the upper part of the Chazy or lower part of the Trenton, should not occur well up in the Trenton. 
parallel to that cleavage, and are presumably calcite; the smaller ones, with neither cleavage nor twinning, may be dolomite, or else calcite crushed along its cleavage. (See p. 19.) The stone effervesces with acid more freely than dolomite. The marble of these quarries seems to be referred to by Hitchcock and Hager. ${ }^{1}$

The strike of the beds is

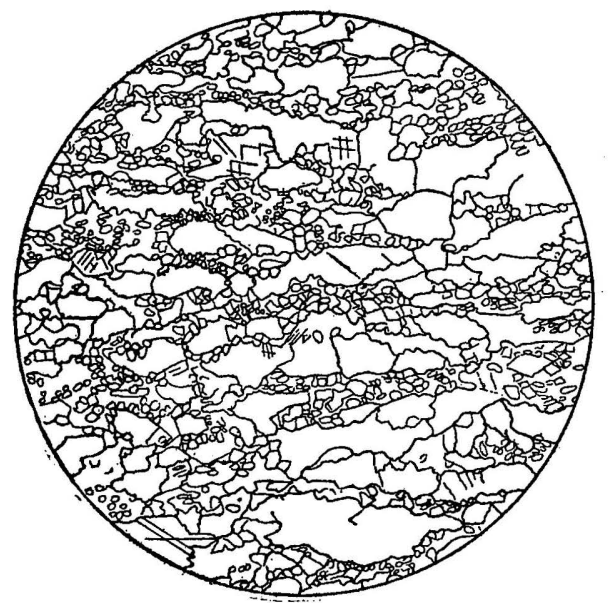

Figure 25.-Thin section of marble from Huntley quarry, Leicester Junction, showing elongate alternate grain texture. Enlarged 77 diameters. N. $15^{\circ} \mathrm{E}$. Beginning on the east there are within a width of 60 feet three synclines, two anticlines, and part of a third, with their axial planes inclined $45^{\circ}-55^{\circ} \mathrm{E}$. From the manner in which the rock breaks from the mass it is evidently still under compressive or tensional strain. It is also rather sonorous. Some of these folds are shown in Perkins's last report. ${ }^{2}$

SWIMMINGTON QUARRY.

About 0.7 mile southeast of the Huntley quarry is the Swimmington quarry of the Leicester Marble Lime Co., not visited by the writer but described by Perkins, ${ }^{3}$ in which a dark-gray (graphitic) marble forms a completely compressed (isoclinal) fold with an almost horizontal axial plane. The fold is about $7 \frac{1}{2}$ feet in diameter and 100 feet long.

The structure at both of these quarries indicates that Leicester Junction marks the location of a north-south zone or axis of intense crustal compression similar to that which passes near the Owls Head, in Dorset. (See p. 93.)

\section{SERPENTINE.}

ROXBURY.

The serpentine quarry, opened before 1858 , is about half a mile south of Roxbury station, and about 600 feet west of the railroad, in Washington County. It measures at the surface 100 feet north to south by 35 feet across, but at the bottom, 70 to 75 feet down, 120 feet north to south by 48 to 50 feet across. A new opening, 500 feet south of the old one, was begun in 1910. Operator, Barney Marble Co., Swanton, Vt.

1 Geology of Vermont, vol. 2, 1861, p. 768.

2 Perkins, G. H., Rept. Vermont State Geologist for 1909-10, Pl. LXIX.

${ }^{8}$ Idem, pp. 349-351, Pls. LII, LXXI. 
The serpentine, "Vermont verde antique" (specimens D, XXXI, 2, c, rough; f, polished), and its geologic relations have been described on page 49.

The serpentine is finished at Swanton and is used for columns, wainscoting, counter tops, base, and tiling. A photograph of a small polished piece is reproduced in Plate VIII, $A, a$.

Specimens: Wainscoting, post office, Danville, Ill.; the Delaware Hotel, Fort Worth, Tex.; New St. Charles Hotel, New Orleans. Columns and panels (10 feet 6 inches by 4 feet 2 inches), Hall of Justice, San Francisco. Counter tops and base, Union Station, Washington, D. C. Base, First National Bank, Chicago. Tiling, city hall, Indianapolis, Ind. The length of columns is limited to 15 feet.

\section{CLASSIFICATION OF VERMONT MARBLES.}

ECONOMIC CLASSIFICATION.

In the following table an attempt has been made to classify for economic purposes all the Vermont marbles described. The grade of texture and the petrographic name of each marble are also given, with page reference to the fuller description.

As the same marble is sometimes used for different purposes the subdivisions are not rigid. Some of the graphitic monumental marbles are used for electric switchboards.

The number of varieties of interior decorative marbles is so large that only the more distinct and important ones are given. 
Constructional.

\begin{tabular}{|c|c|c|c|c|c|c|c|c|}
\hline Trade name. & Quarry. & Location. & Color. & Texture. & Grade. & Grain form. & $\begin{array}{c}\text { Grain } \\
\text { arrange- } \\
\text { ment. }\end{array}$ & Petrographic name. \\
\hline Dorset A.. & Norcross-West Valley. & South Dorset.... & Cream to very light, faintly & Coarse.. & 5 & Irregular.... & Normal & Calcite marble... \\
\hline Dorset B. & Norcross Plateau. & .....do. & Light cream, clouded with light & ...do. & 5 & .... do & ...do. & .....do. \\
\hline & $\begin{array}{l}\text { Dorset Mountain Mar- } \\
\text { ble Co., upper north- } \\
\text { west quarry }\end{array}$ & $\begin{array}{l}\text { Owls Head, Dor- } \\
\text { set. }\end{array}$ & White and also clouded white.. & ...do. & 5 & Regular. & ...do.. & .....do. \\
\hline Dorset Mountain... & Blue Ledge............ & Green Peak. . & Faintly bluish white, mottled & ...do. $\therefore$ & 5 & Irregular. & Uneven. & Calcite marble with dolo- \\
\hline Manchester blue... & Freedley quarries.. & Dorset Mountain & Very light bluish gray....... & ...do. & 5 & ....do. & ...do. & Calcite marble.............. \\
\hline Mahogany. & ......do, & do. & Milk-white. . & ...do. & 5 & Very irreg- & ...do.... & .....do.. \\
\hline Cloud.. & .....do.. & .....do.. & $\begin{array}{l}\text { Light bluish gray, with medi- } \\
\text { um-gray bands up to } 0.2 \\
\text { inch wide. }\end{array}$ & ... do. & 5 & Irregular. & ...do.... & $\begin{array}{l}\text { Calcite marble with little } \\
\text { dolomite beds and lenses } \\
\text { of grade } 1 \text {. }\end{array}$ \\
\hline $\begin{array}{l}\text { White Stone Brook. } \\
\text { Danby............... }\end{array}$ & $\begin{array}{l}\text { White Stone Brook. } \\
\text { Imperial.............. }\end{array}$ & Dorset 1 & $\begin{array}{l}\text { Faintly cream, tinted white, } \\
\text { with fine yellow-grayish } \\
\text { streaks and spots. }\end{array}$ & ...do.. & 5 & $\begin{array}{l}\text { Very irreg- } \\
\text { ular. } \\
\text { Irregular.... }\end{array}$ & $\begin{array}{l}\text { Normal . } \\
\text {...do..... }\end{array}$ & Calcite marble.............. \\
\hline $\begin{array}{l}\text { Clarendon Valley } \\
\text { gray. }\end{array}$ & Clarendon Valley & Clarendo & Very light bluish gray, with & $\ldots d$ & 5 & .....do do & Uneven. & Calcite marble with little \\
\hline Clarendon A........ & Clarendon. & .....do... & $\begin{array}{l}\text { Bluish white, with bands } 0.1 \text { to } \\
0.2 \text { inch wide or rows of spots }\end{array}$ & ...do. & 5 & Regular & ...do... & ...do........ \\
\hline Clarendon dark.... & .....do. & ....do. & $\begin{array}{l}\text { of medium gray. } \\
\text { Light to dark bluish-gray bands } \\
\text { up to } 0.2 \text { inch wide alternating }\end{array}$ & Medium. & 4 & .....do. & ...do.... & $\begin{array}{l}\text { Graphitic calcite marble } \\
\text { in alternating little beds }\end{array}$ \\
\hline $\begin{array}{l}\text { Albertson extra } \\
\text { dark. }\end{array}$ & Albertson.. & West Rutland.. & $\begin{array}{l}\text { Medium bluish gray, with mi- } \\
\text { nutely plicated black streaks } \\
\text { and some whitish ones, both } \\
\text { crossed at various angles by } \\
\text { slightly undulating black } \\
\text { streaks (cleavage planes). }\end{array}$ & ...do.... & 4 & .....do.... & Normal & $\begin{array}{l}\text { maphitic calcite marbie, } \\
\text { the graphite abundant } \\
\text { along little plicated beds } \\
\text { and also along cleavage } \\
\text { planes across them. }\end{array}$ \\
\hline Riverside.. & Riverside. & Proctor & $\begin{array}{l}\text { Slightly bluish white, with } \\
\text { dark-gray bands and spots. }\end{array}$ & Coarse: & $\begin{array}{l}\mathbf{4} \\
\mathbf{5}\end{array}$ & …d. do. & Üneven. & $\begin{array}{l}\text { Calcite marble, with little } \\
\text { lenses and beds of gra- } \\
\text { phitic dolomite of } \\
\text { grade 1. }\end{array}$ \\
\hline
\end{tabular}




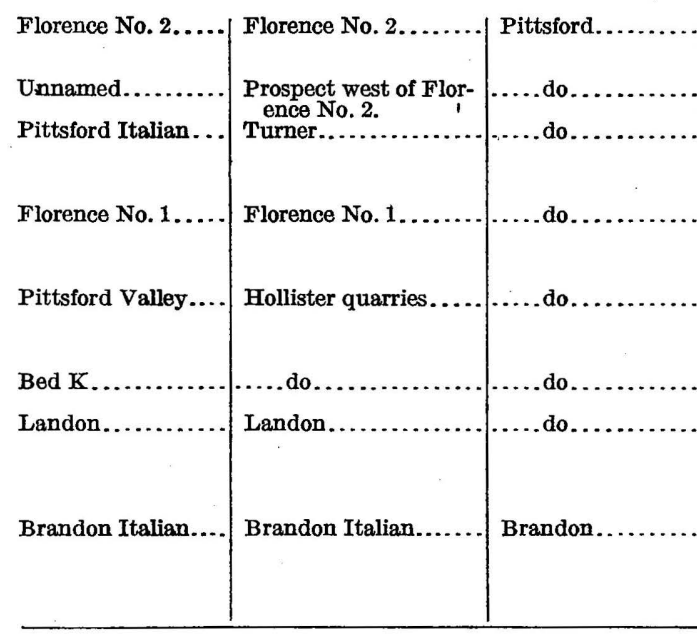

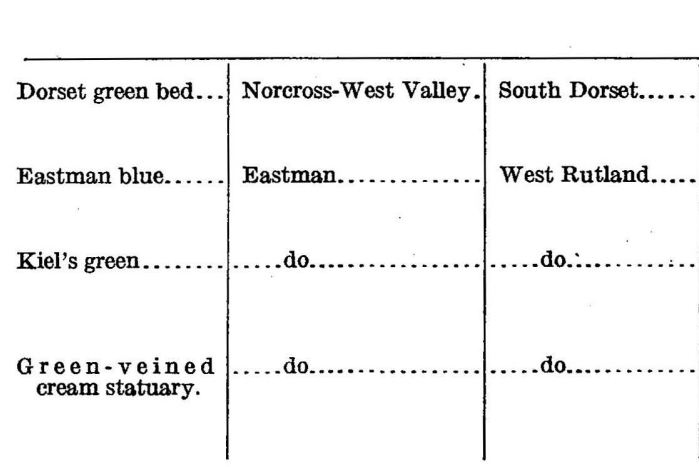

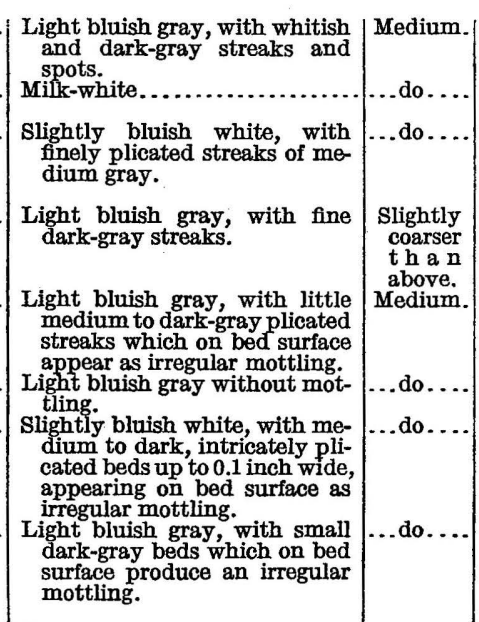

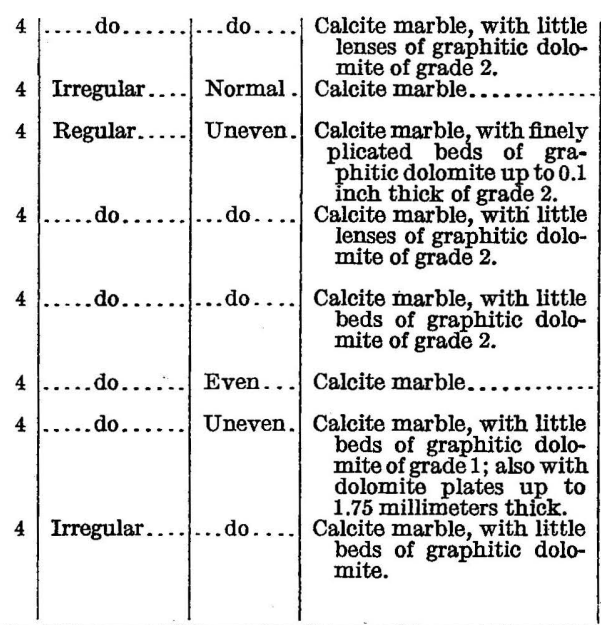

\section{Interior decoration.}

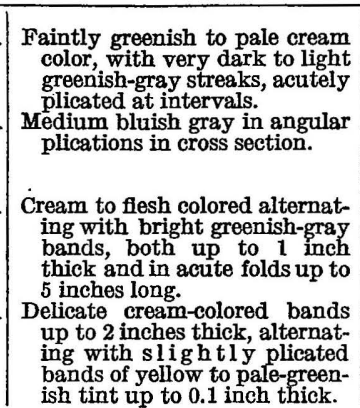

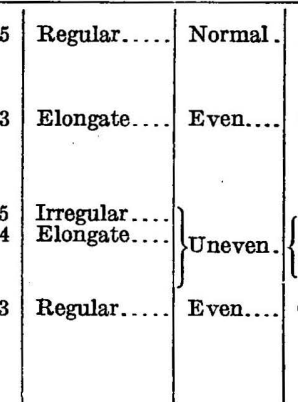

ctinolitic calcite marble, witn little beds of fibrous Fine...

Coarse (cream). Medium Fine....

\begin{tabular}{|c|} 
Coarse... \\
Fine.... \\
\\
Coarse \\
(cream). \\
Medium \\
(gray). \\
Fine.... \\
\end{tabular}
inolite, quartz, etc. with more or less gra-
phitic laminæ, some dolphitic lamic.
omitic.

Calcite marble, interbedded with muscovitic and
chloritic calcite marble.

Calcite marble, slightly limonitic from oxidation of pyrite minute grains.
作
129

$13 \theta$

130

131

133

133 
Economic classification of western Vermont marbles-Continued.

Interior decoration-Continued.

\begin{tabular}{|c|c|c|c|c|c|c|c|c|}
\hline Trade name. & Quarry. & Location. & Color. & Texture. & Grade. & Grain form. & $\begin{array}{c}\text { Grain } \\
\text { arrange- } \\
\text { ment. }\end{array}$ & Petrographic name. \\
\hline Cream statuary. & Eastman . & West Rutland. & $\begin{array}{l}\text { Delicate cream color, with very } \\
\text { pale brown beds up to } 0.1 \\
\text { inch thick. }\end{array}$ & Fine.... & 3 & Regular.... & Even... & $\begin{array}{l}\text { Calcite marble, slightly } \\
\text { limonitic. }\end{array}$ \\
\hline Solid green. & ....do.. & ...do. & Bright greenish gray............. & Extra & 1 & Irregular, & Parallel. & Muscovitic quartzose cal- \\
\hline Light cipolin. & ....do... & .....do.. & Light greenish, with broad pli- & Medium & 4 & (?) & (?) & Muscovitic calcite marble.. \\
\hline Dark cipolin. & ....do.. & ..do. & $\begin{array}{l}\text { Bright light green is h, with } \\
\text { broad plications and alterna- }\end{array}$ & ...do... & 4 & (?) & (?) & $\begin{array}{l}\text { Muscovitic calcite marble, } \\
\text { with chlorite, epidote, }\end{array}$ \\
\hline Bed $\mathbf{M}$. & ....do.. & .. do & Milk-white, with straight paral- & Fine... & 3 & Regular..... & Even.... & Muscovitic (sericitic) cal- \\
\hline Brocadillo... & $\begin{array}{l}\text { Vermont Marble Co., } \\
\text { West Rutland, east } \\
\text { side. }\end{array}$ & ....do. & $\begin{array}{l}\text { Faintly greenish white ground, } \\
\text { with fine greenish-gray pli- } \\
\text { cated bedsand straight streaks } \\
\text { up to } 0.2 \text { inch wide. }\end{array}$ & Medium & 4 & $\begin{array}{l}\text { Irregular, } \\
\text { elongate. }\end{array}$ & Parallel. & $\begin{array}{l}\text { Muscovitic (sericitic) cal- } \\
\text { cite marble with epidote } \\
\text { and chlorite. }\end{array}$ \\
\hline Livido.. & ....do.. & .....do & $\begin{array}{l}\text { Medium to delicate light bluish } \\
\text { gray, with plicated dark-gray } \\
\text { beds up to } 0.1 \text { inch wide. }\end{array}$ & Fine... & 3 & Irregular.... & Uneven. & $\begin{array}{l}\text { Slightly graphitic calcite } \\
\text { marble, with little dolo- } \\
\text { mitic lenses of grade } 1 .\end{array}$ \\
\hline Olivo & $\ldots . d$ & $\ldots \mathrm{d}$ & $\begin{array}{l}\text { Light greenish gray and pale } \\
\text { greenish to white undulating } \\
\text { bands up to on } \theta-\mathrm{h} \text { alf inch } \\
\text { wide. }\end{array}$ & Medium & 4 & $\begin{array}{l}\text { R eg u lar } \\
\text { elongate. }\end{array}$ & Parallel. & $\begin{array}{l}\text { Muscovitic calcite marble, } \\
\text { more micaceous than } \\
\text { brocadillo. }\end{array}$ \\
\hline $\begin{array}{l}\text { American pavo- } \\
\text { nazzo. }\end{array}$ & ......do.. & .....do. & $\begin{array}{l}\text { Milk-white ground, with thin } \\
\text { dark blue-greenish plicated } \\
\text { beds of irregular width and } \\
\text { distribution }\end{array}$ & Fine... & 3 & (?) & (?) & $\begin{array}{l}\text { Chloritic muscovitic cal- } \\
\text { cite marble. }\end{array}$ \\
\hline Rubio..... & & & $\begin{array}{l}\text { Very delicate pinkish ground, } \\
\text { with thin plicated greenish } \\
\text { beds. }\end{array}$ & 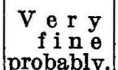 & $\begin{array}{r}2 \\
\text { proba- } \\
\text { bly. }\end{array}$ & (?) & (?) & $\begin{array}{l}\text { Very slightly muscovitic } \\
\text { calcite marble. }\end{array}$ \\
\hline Ruvaro. & $\begin{array}{l}\text { Monkton Ver mont } \\
\text { Marble Co. }\end{array}$ & Monkton & Mottled pink and white........ & $\begin{array}{c}\text { Extra } \\
\text { fine. }\end{array}$ & $i$ & $\begin{array}{l}\text { Plates and } \\
\text { rhombs. }\end{array}$ & Uneven. & $\begin{array}{l}\text { Hematitic untwinned dol- } \\
\text { omite. }\end{array}$ \\
\hline Lyonnaise.. & $\begin{array}{l}\text { Barney....... } \\
\text {.....do......... }\end{array}$ & Swanton & $\begin{array}{l}\text { Dark reddish brown, with irreg- } \\
\text { ular slightly lighter clouds } \\
\text { and some whitish streaks. } \\
\text { Merging forms of brownish red, } \\
\text { with interspaces filled with } \\
\text { white. }\end{array}$ & \begin{tabular}{|}
$\ldots . d o . . .$. \\
...do.....
\end{tabular} & 1 & ...do. & ...do.... & $\begin{array}{l}\text { Hematitic untwinned dol- } \\
\text { omite with quartz grains } \\
\text { and kaolin. } \\
\text { Hematitic untwinned dol- } \\
\text { omite with interspaces } \\
\text { of white twinned dolo- } \\
\text { mite and quartz. }\end{array}$ \\
\hline
\end{tabular}




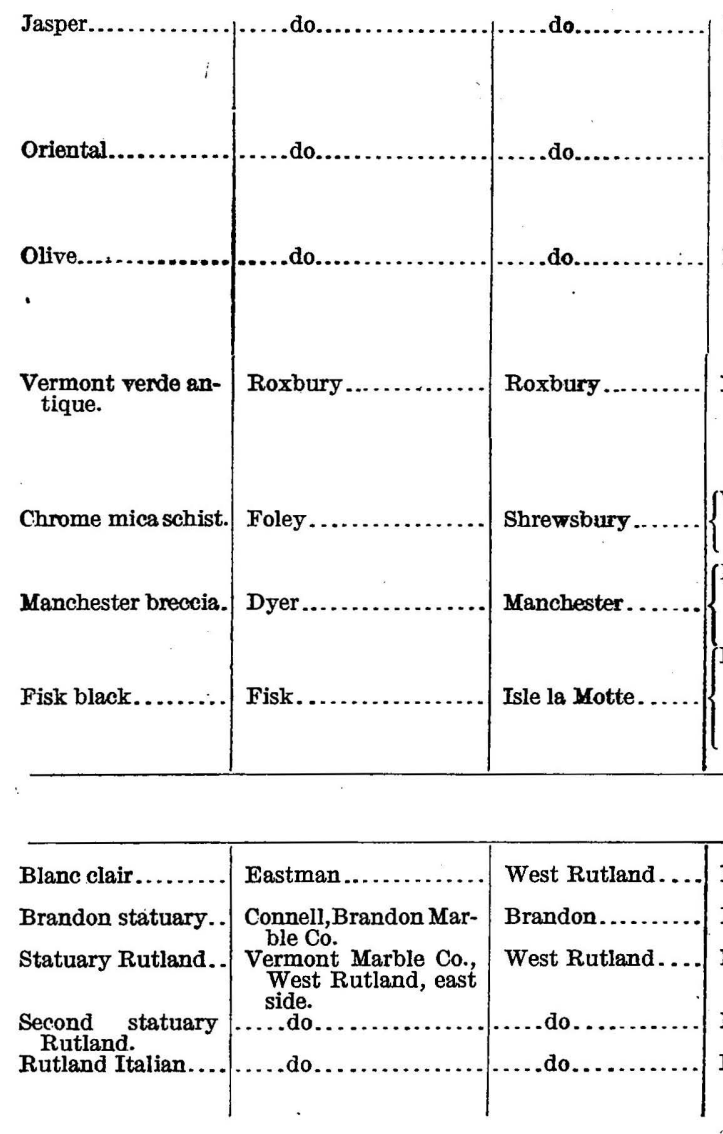

Bright reddish ground, with pinkish and white irregular .

Dark reddish-brown ground, with spots.

Light, faintly greenish gray ground, with lenses more or light pinkish gray, some with white nucleus.

Dark purplish-greenish ground, black when polished, with network of intersecting whit hat

Verdigris-green to faintly greenish gray, but when polished

Bright brick-reddish cement inclosing fragments of cream deep-reddish marble. Extremely dark gray ("black") almost jet-black when polished, with here and there sections of large white marine
gastropod shells.
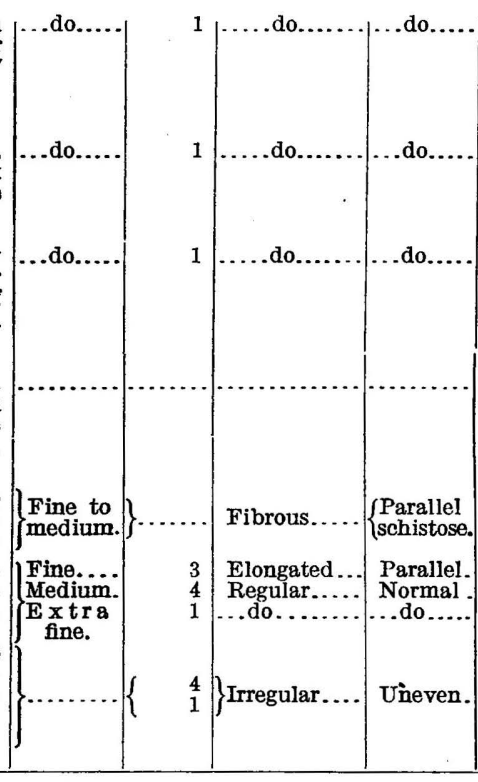

Ground like that of royal red, with magnetite, corals of coarsely twinned mite some with nucleus Ground like that of royal red; purplish parts of magnetite more or les oxdazed, white parts of calcite and dolomite. Ground of untwinned doland kaolin. The lense contain twinned dolo mite and have border of oxidized pyrite.

. ibrous and eins of magnesite and tarticle

hrome mica (fuchsite) with chlorite magnetite.

Calcite and dolomite marble breccia and hematitic calcitic cement.

Carbonaceous, slightly dolomitic fossiliferous, ca] morphic origin.

Monumental.

(1)

\begin{tabular}{l|l|}
$\begin{array}{l}\text { Milk-white, in places faintly } \\
\text { clouded. } \\
\text { Faintly ivory-tinted............. }\end{array}$ & Very fine \\
Milk-white....................... & ...do.... \\
$\begin{array}{l}\text { Milk-white, with faint grayish } \\
\text { to yellowish clouds. } \\
\text { Faintly bluish white, with faint } \\
\text { irregular grayish and yellow- } \\
\text { brownish mottling. }\end{array}$ & Medium \\
\hline
\end{tabular}

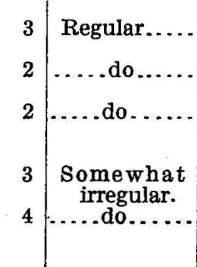

\begin{tabular}{|c|c|}
\hline Normal & Calcite marble........... \\
\hline ..do. & .....do. \\
\hline do. & .....do. \\
\hline ...do. & .....do. . \\
\hline.$d$ & ....do. \\
\hline
\end{tabular}


Economic classification of western Vermont marbles-Continued.

Monumental-Continued.

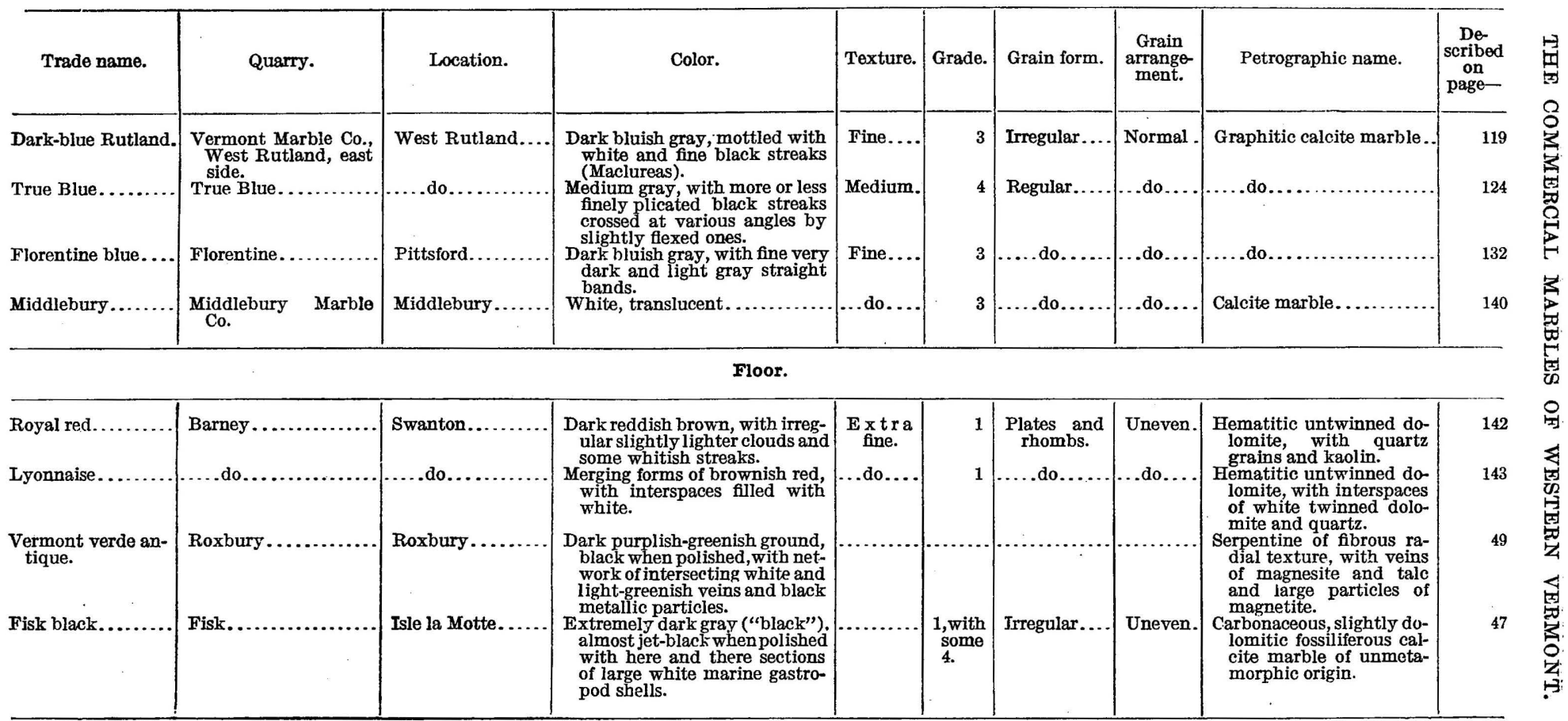




\section{SCIENTIFIC CLASSIFICATION.}

The marbles of western Vermont fall naturally into the following 12 petrographic groups:

Scientific classification of western Vermont marbles.

1. Calcite marbles.................

2. Graphitic calcite marbles............... $\left\{\begin{array}{l}\text { True Blue. } \\ \text { Florentine. } \\ \text { Dark-blue Rutland. }\end{array}\right.$

3. Muscovitic calcite marbles................. $\left\{\begin{array}{l}\text { Brocadillo. } \\ \text { Solid green (Eastman). }\end{array}\right.$

4. Chloritic and muscovitic calcite marbles......... American pavonazzo.

5. Actinolitic calcite marbles................. Dorset green bed.

6. Calcite marbles with minute dolomitic lenses and
beds, usually graphitic.

7. Brecciated calcite and dolomite marble, with hematitic cement........................Manchester.

8. Carbonaceous slightly dolomitic unmetamorphic calcite marble ........................... Fisk black.

9. Graphitic dolomite marble................. Parker \& Pinckney.

10. Hematitic untwinned dolomite marble with quartz grains ........................... Swanton.

11. Serpentine............................... Vermont verde antique.

12. Chrome mica (fuchsite) schist ................ Foley quarry, Shrewsbury.

Some of the calcite marbles of groups 1,5 , and 6 are tinted cream color, probably by oxidized pyrite or bluish by graphite, both in grains of infinitesimal size. Group 3 contains a very little chlorite and in some marbles epidote.

\section{RELATIVE VALUES OF VERMONT MARBLES.}

To assist the reader in getting a correct idea of the relative qualities and abundance of these marbles, the prices current in 1910 of $a$ few of them are given. These prices are all f. $o$. b. at the nearest railroad for blocks of ordinary sizes in the rough.

Prices per cubic foot of Vermont marbles, 1910.

Dorset A and Dorset green bed.

Dorset Mountain quarries, for exteriors...................

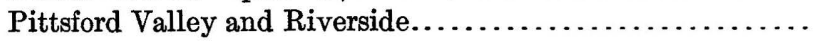

Common Rutland blue.

2.00

Other "blue" marbles.

Statuary Rutland

11.50

Other Rutland fine white marbles................... 4.00-8.50

Colored Rutland marbles (Vermont Marble Co.) for interiors 2. 00-6. 50

Eastman colored marbles for interiors.

$2.75-4.50$ 


\section{MARBLE MACFINERY.}

No attempt has been made to list the machines in use at the quarries. The purpose of this publication will, however, be served by a brief reference to the most improved marble machinery and by designating the quarries and works where it has been introduced. - The channeler and gadder for vertical and horizontal cutting are in general use. The recent improvements consist in the substitution of electricity for steam in these operations and in the introduction of carborundum wheels in the finishing department.

The Vermont Marble Co. is using in its West Rutland tunnels channeling and drilling machines driven by air compressed by electricity at each machine. It also has an electric railroad 1,300 feet long at a depth of 240 feet connecting several of its West Rutland quarries.

The most improved marble mill is that erected by the RutlandFlorence Marble Co. at Fowler, which in May, 1911, passed into the hands of the Vermont Marble Co. This mill has a capacity for 60 gangs of marble saws, 43 of which are installed. A derrick car running on a central track the entire length of the building delivers the blocks to transverse tracks running under the gangs of saws on either side.

The Vermont Marble Co. uses a vertical diamond saw one-sixteenth of an inch thick and 7 feet in diameter and the Norcross-West Marble Co. one 5 feet in diameter. The diamonds are about 1 inch apart.

The Manchester Marble Co. and the Barney Marble Co. use a carborundum coper and molder.

The Norcross-West Marble Co. uses a coring machine for monolithic circular columns up to 7 feet long and 3 feet 6 inches in diameter. The same firm has lathes for columns 22 feet long and 4 feet in diameter and the Vermont Marble Co. one for columns 29 feet 9 inches long and 3 feet 4 inches in diameter. The most systematic storage yard is that of the Vermont Marble Co. at West Rutland, with its great traveling crane for the distribution of blocks.

\section{ADAPTATIONS OF THE MARBLES OF WESTERN VERMONT.}

The table on pages 150-154 shows the general adaptations of the marbles of western Vermont for construction, interior decoration, monuments, statuary, and flooring. The constructional marbles range from the coarse whitish ones of South Dorset and the milk-white and cream-tinted ones of Dorset Mountain to the mottled ones of Green Peak, Pittsford, Proctor, and Brandon and the medium bluish gray of the Albertson, Florentine, and True Blue quarries. These graphitic marbles are particularly well suited for rock-faced construction in the soot-laden atmosphere of cities, where white 
marbles become streaked in a very few years. They are also much in demand for electric switchboards, on account of their content of graphite and their lack of magnetite.

The range of marbles suitable for interior decoration is very wide, including the variously tinted West Rutland marbles, the "Champlain marbles," the serpentine of Roxbury, and the dark emeraldgreen chrome mica schist of Shrewsbury. The prevalent use of large panels of polished banded marbles has brought about in recent years a considerable demand for these West Rutland marbles and for the actinolite marble of South Dorset. The supply of the finer grades of monumental marbles, particularly of the "statuary Rutland," is at present somewhat scanty, but there is reason to hope that as the marble belts are explored more scientifically it will be found to be much more ample.

The at present unused fine-grained dolomite marbles of Pittsford, which from their fine quartz veining and thin bedding can hardly be expected to furnish many large slabs, are yet very well adapted for mosaic work and terrazzo.

The lists of architectural specimens given after the description of each of the typical marbles, supplemented by Plates VII, XI, XIII, and XIV, illustrate their more important adaptations.

\section{GENERAL OBSERVATIONS AND PROGNOSTICATIONS.}

Upon careful inspection of the geologic map and of the stratigraphic and marble succession, as tabulated on pages 66, 96, it will be noticed that between Shaftsbury on the south and Middlebury on the north marble is to be expected chiefly along two geologic boundaries - that with the underlying dolomite series and that with the overlying schist series. It will also be observed from the symbols on the map that the portions of these boundaries along which marble has been or is being quarried constitute but a very small part of the entire boundaries.

The boundary with the dolomite, between Shaftsbury and Middlebury, actually measures 91 miles, to which should be added a few miles between Clarendon and Rutland. The boundary with the schist, between Shaftsbury and the north end of the Taconic Range in Brandon in the main valleys - that is, exclusive of the areas in Sandgate and the West Rutland Valley and the small marble area east of Biddie Knob in Pittsford-measures 93 miles. The boundary with the schist on both sides of the West Rutland anticlinal valley and in the small area east of Biddie Knob measures $15 \frac{1}{2}$ miles. The total length of these boundaries is $199 \frac{1}{2}$ miles

From these figures should be deducted those portions of the boundary already fully prospected or being worked. These amount to 8 miles in Pittsford, Proctor, Brandon, and Middlebury, along the 
lower boundary; 7 miles in Clarendon, Pittsford, and Proctor along the upper boundary; and 2 miles along the upper boundary in the West Rutland Valley-a total of 17 miles.

As large portions of the boundary are covered with a thick overburden of sand, gravel, or clay, the removal of which would be very costly, and as in many other places the marble is defective from much jointing, due to dikes or from reeds or irregular fractures, a considerable deduction should be made from the marble boundaries on this account. In order to err on the safe side, this unprofitable part is estimated at 75 per cent.

After making these deductions, the estimates of the unworked parts are as follows: Parts of marble belt contiguous to basal dolomite, 20 miles; parts contiguous to schist, 21 miles; parts in West Rutland Valley and in area east of Biddie Knob; $3 \frac{1}{2}$ miles. The unworked profitable portions of the marble boundaries thus probably aggregate $44 \frac{1}{2}$ linear miles.

The folded character of the structure should always be kept in mind. If good marbles occur on the east side of the schist mass which forms the southern part of Dorset Mountain, the same marbles should be expected on the west side of that ridge in Dorset Hollow. Similarly, the marble beds exposed on the east side of the West Rutland Valley, dipping east under the synclinal schist ridge, should be expected under normal geologic relations to recur on the east side of that ridge, about three-fourths of a mile west of Center Rutland.

The actual depth of the glacial and postglacial deposits upon the eroded marble surface can not be prognosticated. It must be determined by boring. . If the aid of a geologic map and sections, even with all their uncertainties, is to be discarded, 10 feet of gravel or clay may be sufficient to conceal the presence of marble beds of as fine a quality as any now being worked.

In view of the great variety and value of the marble exposed on both sides of the West Rutland anticline, it would seem that, on scientific principles, the portion of the marble boundary which should first be explored is that on the west side of the West Rutland anticlinal valley and next that on the east side of the synclinal ridge east of that valley, or, more exactly, from the intersection of the West Rut-. land and Rutland town lines with the highway, about three-fourths of a mile southwest of Center Rutland, north and northwestward for a distance of 2 miles, to a point about a mile south of the Riverside quarry.

Finally, inasmuch as some members of the marble succession are absent between the basal dolomite and the schist ridge west of Proctor-possibly as shown in section $\mathrm{H}$, Plate III, owing to faultingand as the structural conditions appear to be much more favorable in Pittsford, the half-mile strip west of Fowler, between the railroad 
branches and the schist ridge on the west, ought to be carefully explored for these missing beds, and in like manner the territory between the Hollister quarry and the schist ridge.

\section{SCIENTIFIC PROSPECTING FOR MARBLE.}

While the practical judgment of a competent marble quarryman or marble cutter will always be required to determine whether a particular bed of a certain quality of marble is conveniently situated for quarrying and is also free from reeds or other blemishes, the scientific basis for marble prospecting in this region is afforded by the geologic maps (Pls. I and IV), the-section (Pls. II and III), and the table of the marble series as given on page 96 . With these and a careful reading of the paragraphs in the section entitled "Geologic principles governing the marble belt," pages 77-85, correct methods of prospecting will readily suggest themselves. The following hints may be helpful to some readers:

On the map the marble-schist boundary shows where the upper part of the marble series is to be expected and the dolomite-marble boundary where its lower part will probably be found. The first step is to determine the approximate position in the marble succession of the locality or beds to be prospected. This can be done by estimating their vertical distance from one of the determined stratigraphic levels, either the schist or the dolomite boundary, or from the intermediate dolomite, if its course has been traced. That vertical distance, of course, is the distance at right angles to the beds, but the prospector should make sure that these are not duplicated by folding. The same result may be obtained in some places by measuring the distance of the locality or bed from the line of strike of any quarried bed of known position. If the schist is near at hand, the beds to be expected in its vicinity are those of the upper graphitic marbles, except on Dorset Mountain. Where the upper graphitic marbles occur, if the white and muscovitic marbles are desired, they should be sought below the graphitic marbles. If the area lies between the basal dolomite and the intermediate dolomite, the lower clouded marble is, of course, to be expected in that position.

After the beds have been exposed by the usual cross trenching, their character should be carefully studied to determine the nature of the folding. If repetitions occur, then the arch or trough form of the fold and the degree of its pitch should be ascertained. In general, the part of a fold upon which a quarry is situated or is to be opened shoúld be known and its remaining parts theoretically located, so that when quarrying operations are extended this may be done on rational principles, 
If a quarry or proposed quarry lies immediately west of the intermediate or basal dolomite, the depth at which the dolomite underlies the marble at the turn of the trough should be determined by drilling.

Wherever the beds between two highly inclined parallel beds of dolomite show a tendency to form horizontal zigzags, the probability is that the beds on either side are continuous either below or abovethat is, they constitute a compressed fold, anticline or syncline. Core drilling should then be done to determine whether the fold is a syncline and to ascertain its depth. In all core drilling the cores should be carefully inspected with a view to determining any duplication of beds-that is, evidence of folding-as it may have an important bearing on the operations of the quarry.

A wide margin should be given to dikes and reedy passages, and in opening quarries places with protective clay or till should be preferred.

\section{TESTING OF MARBLE.}

The more important tests of marble for economic uses are described below.

Chemical analysis.- This should have special reference to the content of iron sulphide or oxide.

Microscopic analysis.-For this purpose a number of thin sections should be made from cubes sawed, not hammered, from blocks taken at different heights in the same bed and horizontally far apart, and some sections should be cut transverse to the bed, others parallel to it.

The microscopic analysis should determine the grain form, the grain regularity, the average grain diameter by the Rosiwal method, the associated minerals and their relative abundance, and the presence of minute beds or lenses of dolomite and of divisional planes of bedding or cleavage.

Absorption.-Hirschwald ${ }^{1}$ found that after Carrara marble was exposed on all the 23 rainy days of November and December, 1900, its maximum water absorption was 0.45 per cent and that the same marble when tested experimentally in the laboratory showed after one hour's immersion 0.49 per cent of absorption. He also found ${ }^{2}$ that the water absorption of a coarse Tyrolese marble under slow immersion amounted to 0.74 per cent of the stone, in vacuum 0.82 per cent, and under pressure of 50 to 150 atmospheres 0.92 per cent, and that the water absorption of this stone thus tested amounted to 81.37 per cent of its total pore space, or in vacuum 90.01 per cènt.

Porosity.-One of the simplest methods of determining porosity is to expose sawed blocks 2 by 1 by 1 inch for a few hours to a tempera-

\footnotetext{
1 Hirschwald, J., Die Prüfung der natürlichen Bausteine auf ihre Wetterbeständigkeit, Berlin, 1908, p. 212 .

2 Idem, p. 156.
} 
ture of about $104^{\circ} \mathrm{F}$. and then to immerse them for 48 hours in a concentrated 4 per cent alcoholic solution of nigrosine, a deep-blue dye soluble in alcohol. ${ }^{1}$ After drying for half an hour the blocks are to be broken squarely across with hammer and chisel. The degree of porosity will be indicated by the extent to which the dye has penetrated the blocks.

The importance of determining the porosity of marble and the disregard of it by some architects and builders is shown by the frequent combination of metals and marble on exposed faces. The metal inevitably oxidizes and the marble absorbs the oxide and becomes discolored. In the Forefathers' Monument at Plymouth one of the delicate bas-reliefs of white marble in the buttress of the base is stained bright vermilion. The stain appears to have been derived from red lead used in fastening the marble to the granite and to have been absorbed by the marble at the back of the slab and thus found its way to the carving on the front.

Compressive strength.-This should be tested on 6-inch sawed cubes with hydraulic compressor, as in the Watertown Arsenal tests. One set of blocks should be tested on the bed and another on edge.

Transverse strength.--This should be tested on sawed blocks between supports and both on bed and on edge.

Tensional strength or cohesion.-This should be tested by a method described by Hirschwald. ${ }^{2}$ A sawed block of certain shape with lateral grooves in the center is fastened at each end into a steel frame provided with a hook. The tensional weight is applied to one of the hooks and the block is suspended by the other.

Magnetism.-A marble for use in electric switchboards should contain little or no magnetite. There is probably a slight difference in the amount of this mineral in different marbles, although the quantity in any one is exceedingly small. Its effect on an electric current should therefore be tested.

Translucence.-Marbles differ considerably in translucence, which can be tested by sawing very thin pieces of measured thickness and superposing them in order to determine the thickness traversed by light.

Polish.-A polished surface should be examined with a magnifier and the pits or protuberances noted.

Durability of color.-This can be determined by exposing a sandrubbed and a polished surface to the south for three years and then comparing the surfaces with those of unexposed pieces prepared from the same block at the same time.

\footnotetext{
1 Made by Jäger at Barmen, Germany, and recommended by Hirschwald (op. cit., p. 163).

2 Op. cit., pp. 171,172 .

$49311^{\circ}-$ Bull. $521-12-11$
} 
Sonorousness.-This is an index of cohesion. It can be tested by hammering sawed slabs 2 inches thick, 4 to 6 inches wide, and 1 to 2 feet long.

\section{Statuary test.-Renwick ${ }^{1}$ makes this recommendation:}

Marble for statuary purposes should never be selected in bright weather. Veinings and discolorations are more difficult of discovery at this time than at any other. A dull day with a good light is the best time for inspections; if after a shower of rain, so much the better. Provided no rain has fallen, the blocks should be soused with water; veins and stains can then be more readily perceived. If possible, have each block slung and struck with a hammer. If the sound of the blow is dull and heavy, look out for cracks. Should a hard, metallic tone be emitted the marble will be heavy in working; but if a soft, clear ring is heard, the material is sound and will both work and wear well.

\section{GLOSSARY OF TECHNICAL TERMS.}

Actinolite. A greenish mineral of the hornblende group, a silicate of lime, iron, and magnesia $(\mathrm{MgFe})_{3} \mathrm{CaSi}_{4} \mathrm{O}_{12}$.

Amygdule. A small globular cavity in an eruptive rock caused by steam or vapor at the time of its eruption, and generally lined afterwards with secondary minerals.

Anticline. The arch part of a wavelike bed of rock.

Bed. A continuous mass of material (sediment) deposited under water at about one time.

Biotite. A brownish to black mica containing a considerable percentage of iron and magnesia.

Brachiopod. A small marine animal, generally with a bivalve shell and provided with two ribbon-like respiratory organs near the mouth, which also serve to draw currents of water to the mouth.

Breccia. Rock made up of angular fragments produced by crushing due to a crustal movement and then recemented by infiltrating mineral solutions.

Calcite. The mineral consisting of lime carbonate $\left(\mathrm{CaCO}_{3}\right)$ which constitutes most of the commercial white marbles. (See p. 24.)

Cambrian. The lowest division of Paleozoic time. Marked by abundant marine invertebrate life. Preceded the Ordovician.

Cephalopoda. The most highly organized of the mollusks, represented by the modern nautilus, squid, and cuttlefish, but in early geologic periods by many species with coiled or straight shells having compartments for air or gas.

Chlorite. A soft bluish-green foliaceous mineral, a hydrous silicate of alumina, iron, and magnesia.

Cleavage. When applied to a mineral designates a structure consequent upon the geometric arrangement of its molecules at the time of its formation.

Conformity. When one bed overlies another in parallelism, without any disturbance of the crust having affected the lower one before the deposition of the second, they are said to be in conformity.

Crinoids. Marine animals related to starfishes and sea urchins but mostly with plantlike calcareous skeletons rooted and provided with an articulated stem bearing a cup containing the alimentary organs.

Cryptocrystalline. Applied to a rock whose crystalline texture is obscure.

Crystalline. When the molecules of a mineral are arranged in geometric order the mineral is said to be crystalline.

Dike. Natural molten material erupted through a narrow fissure in rock. 
Dip. The degree and the direction of the inclination of a bed, cleavage plane, joint, etc.

Drift. Sand and bowlders deposited by a glacier, continental or local.

Dolomite. A lime and magnesia earbonate. (See p. 27.)

Dolomitization. The process by which a limestone (lime carbonate) may be changed to a dolomite. (See p. 33.)

Epidote. A grass-greenish mineral, a silicate of alumina, iron, and lime- $\mathrm{Ca}_{2}$ $(\mathrm{AlOH})(\mathrm{AlFe})_{2}\left(\mathrm{SiO}_{4}\right)_{3}$.

Erosion. The wear of a rock surface by natural, mechanical, or chemical agencies.

Fault. A fracture resulting in the dislocation of the bedding or cleavage of a rock or vein, one part sliding up or down or both changing positions along the fracture.

Formation. A group of beds possessing some common general characteristic or fossil forms differing from those of the beds above and below.

Galenite. A mineral composed of lead sulphide ( $\mathrm{PbS})$, the common ore of lead.

Gastropods. A group of mollusks including land, fresh-water, and marine snails

Gneiss. When the minerals of a granite or granite-like rock under powerful compression assume a certain parallelism it becomes a gneiss.

Hematite. An oxide of iron $\left(\mathrm{Fe}_{2} \mathrm{O}_{3}\right)$ which when scratched or powdered gives a cherry-red color or "streak."

Kaolin. A hydrous silicate of alumina derived from the alteration of feldspar.

Limonite. A hydrous oxide of iron $\left(2 \mathrm{Fe}_{2} \mathrm{O}_{3} \cdot 3 \mathrm{H}_{2} \mathrm{O}\right)$; a hydrated hematite, which, when scratched or powdered, gives a brownish rust color.

Maclurea. An extinct marine gastropod in which the whorls of the shell lie in one plane. Some of the Maclureas of the Lake Champlain region attain several inches in diameter.

Magnetite. A black metallic mineral $\left(\mathrm{FeO}\right.$ and $\left.\mathrm{Fe}_{2} \mathrm{O}_{3}\right)$ known by its strong magnetism and its black streak. One of the principal ores of iron.

Matrix. The general mass of a rock which has isolated crystals or mineral particles, sometimes called the groundmass.

Metamorphism. The process, partly physical, partly chemical, by which a rock is altered in the molecular structure of its constituent minerals and frequently in the arrangement of its particles. If the cause of the process is a general crustal movement the metamorphism is said to be regional or dynamic, but if its cause is mainly the contact with a molten intrusive rock, it is called contact metamorphism.

Millimeter. French decimal linear measure, the thousandth part of a meter or the tenth part of a centimeter. It is equivalent to 0.03937 inch, the meter being 39.37 inches.

Monolith. A column or monument of one stone.

Muscovite. Potash mica, the most common of the micas, generally of whitish to greenish color. Mainly a silicate of alumina and potash.

Oolitic. Term applied to limestone and other rocks when they consist largely of minute spherules and resemble the roe of fishes.

Ordovician. One of the great divisions of Paleozoic time, formerly called "Lower Silurian."

Pelitomorphic. Literally, having clay or mud form. Applied to a rock of claylike texture.

Pitch. The inclination of the axis of a fold of rock.

Plagioclase. A term applied to all those feldspars that are not potash feldspars.

Polarized light. Light whose vibrations, unlike those of ordinary light, which extend in all directions, are in only one plane. Polarized light is used to distinguish minerals, particularly colorless, transparent ones, under the microscope. Minerals, like calcite or dolomite, that polarize light are of crystalline texture, but these do not polarize light in the direction of their vertical crystal axis. 
Porphyritic. A term applied to rock texture to designate the presence of isolated crystals in a general mass (matrix or groundmass) of finer material.

Pteropod. An order of gastropod mollusks living at or near the surface of the ocean and provided with a pair of fleshy appendages on either side of the mouth which serve as fins. Many of them have more or less conical shells which form extensive deposits on the ocean floor. Shells closely resembling those of pteropods abound in rocks of Cambrian age. (See p. 66.)

Pyrite. Iron disulphide $\left(\mathrm{FeS}_{2}\right)$, the common light brasslike metallic mineral, generally injurious to building stones.

Quartzite. A metamorphosed quartz sandstone in which the cement which unites the quartz grains is also quartz.

Rhizopods. Animals of very low order and organization, consisting mainly of transparent protoplasm. Some of them have a calcareous case. They abound in the ocean, and their remains form extensive oozes on the ocean floor.

Rhombohedron. A crystal form bounded by six faces of rhombic outline.

Schist. A crystalline rock made up of flattish particles arranged in rough parallelism, some or all of which have crystallized under pressure.

Sedimentation. The deposition of particles, usually under water. A sedimentary rock is one consisting of particles thus deposited.

Sericite. A ribbon-like or fibrous form of muscovite or potash mica.

Serpentine. A hydrous silicate of magnesia and iron. (See p. 49.)

Slickensides. The polished and grooved faces of a joint or bed caused by the motion and friction of adjacent rock masses.

Slip cleavage. A cleavage arising from slippage along fractured microscopic folds.

Specific gravity. The weight of a rock or mineral compared to that of a body of distilled water of the same bulk.

Strike. The direction at right angles to the inclination of a plane of bedding, joint, etc.

Syncline. The trough part of a wavelike sheet or bed of rock.

Trilobite. A crustacean with affinities to the horseshoe crab of the eastern coast and generally marked by the division of the back into three lobes lengthwise and crosiswise. Trilobites were very abundant in early geologic time.

Twinning plane. In calcite and dolomite this is the plane which separates two adjacent crystals which have formed with the poles of their main axes in different directions.

Unconformity. When the lower one of two contiguous deposits affords evidence of having been exposed to atmospheric erosion before the deposition of the upper one, there is said to be an unconformity between them.

Vein. When correctly used, denotes a more or less irregular, sometimes ramifying mineral mass within a rock. It should never be confounded with a bed. 


\section{INDEX.}

A.

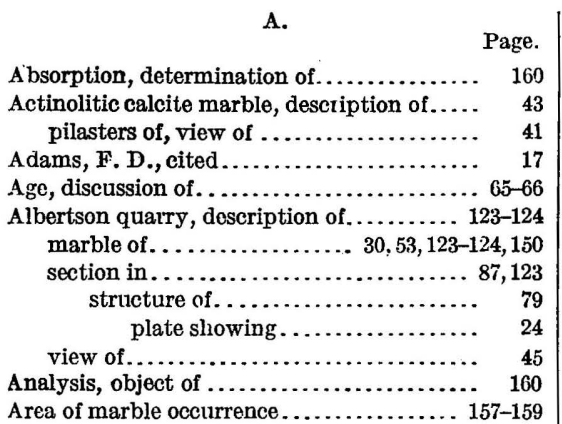

B.

Barney Marble Co., machinery of.......... 156 quarries of. See Swanton; Fisk quarry; Roxbury, serpentine of.

Bartlett, W. C., cited.

Baxter quarry, location of. ................

Bear Mountain, marble or marble of, bedding and cleavage of, figure showing.......................

T3edding in schist, figure showing. .......... occurrence and character of . ............ 81-82

Beds. See Marbles of western Vermont, beds of.

Belts. See Marbles of western Vermont, belts of.

Bennington, geology near................

Bennington quarry, location and ownership of.......................... 98

Bibliography ........................ 59-60

Blue Ledge quarry, description of........... 104

marble of . . . ................. 65, 104,150

Boardman Hill, marble near. . . ........ 32, 39-40

Brandon, marble near....... 42, 47, 52,54, 135-139 marble near, folds in............... 78,80

folds in, figure showing ............. 78

thin section of, figure showing....... 42

Brandon Italian quarry, description of. . .. 135-137 marble of . ................... 136-137,151

thin section of, figure showing....... 136

structure at, figure showing........... 136

Brandon Italian Fligh Street quarry, description of.................. 137

marble of $\ldots \ldots \ldots \ldots \ldots \ldots \ldots \ldots \ldots . .137$

Brandon Lime \& Marble Co. quarry. See Huntley quarry.

Prandon Marble Co. quarry. See Connell quarry. c.

Page.

Calcareons matter, deposition of. ............ 21-22

Calcite marble, character of. . . . . . . . . . . 24-27

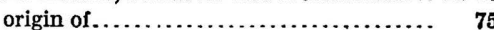

quarries of, description of. . . . ........ 97-146

relation of, to dolomite............... 29-33

figure showing.................... 31

thin sections of, figures showing....... 19,

$25,41,42,47,99,134,140$

texture of. ......................... 51-54

Camptonite, analysis of ................. 72

dikes of ........................... $72-73$

Carrara marble, analyses of .............. 14

description of ...................... 25,27

physical properties of .............. 16,17,54

strength of ......................... 16

Caves, formation of ........................ 84-85

Center Rutland, marble near............. 71-72

Chalk, nature of........................ 12

Champlain marbles, description of......... 43-46 See also Swanton; Monkton.

Chapin prospect, location of .............. 142

Chemical analysis, object of ................ 160

Chippenhook, geology near............... 64

Chrome mica schist, occurrence and charac-
ter of........................

Clarendon, marble near......... 32, 52, 53, 110-112

quarries near.................... 110-112

Clarendon quarry, description of........ 111-112 marble of .................. 40,111-112,150 section of ........................ 111

Clarendon Valley quarry, description of .......110-111 marble of .................. 51,110-111,150

Clarke, F. W., cited..................... 35

Classification of marbles, table showing.... 149-155

Clay, protection of marble by.............. 85 protection of marble by, plate showing .. . 132

Cleavage, figures showing............... 45,81 occurrence and character of............ 81-83

Clement quarry. See West Rutland quarries.

Clouded calcite marble, description of.... 40-41, 53 slab of, view of.................... 41

thin section of, figure showing.......... 134

Color, tests for......................... 161

Columbian Marble Co. quarries. See Umbrella quarry; Monkton quarry.

Columbian quarry, description of............ 127

dike near............................. 73

marble of, and near................. 127

analysis of........................ 13

section of ............................ 89

structure of, plate showing............. 24 
Connecticut, marble from ................

Connell quarry, description of............. 138 marble of . . . . . . . . . . . . . . . . . 138, 153

Continental Marble Co. quarry, location of. . marble of.

Cony beare, W., cited

Coral, formation of dolomite from ..........

Correlation of marbles, data on

Covered quarry. See West Rutland quarries.

\section{D.}

Dale, N. C., work of ....................

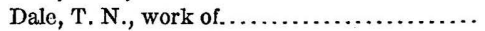

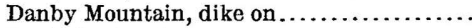

Daubrée, A., cited ................... 23

Day quarry, description of. ............ 146-147 marble of . . . . . . . . . . . . 22-23, 52, 146-147 origin of .....................22-23

Deaf Joe quarry, description of........... 103 marble of . ...................... 103

Depretz, -

Dieulafait, —, on marbles........... 15

Dikes, analysis of . . . . . . . . . . . . . . 72 joints near, plate showing........... 72 occurrence and character of ..... 72-74, 76, 83-84

Diller, J. S., cited..................... $\quad 50$ work of ........................... 10

Doelter, C., and Hoernes, K., cited......... 34

Dolomite marble, analysis of . . . ......... $\quad 36$ character of . . . . . . . . . . . . . . . . . . . 27-29 origin of. . . . . . . . . . quarries of, description of . . . . . . . . . 97-146 relation of, to calcite marble.......... 29-33

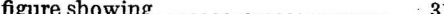
thin sections of, figures showing....... 28,44

Dorset Mountain, caves near............ 85 dike on . . . . . . . . . . . . . . . marbles of and near. $52-53,54,64,70,83-84,94-95$ section of................... 94-95,96 structure of ................. 79

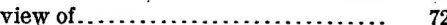
quarries on ..................... 105-110 view in ........................ 72 schist on, figure showing ............ 81

Dorset Mountain Marble Co., quarries. See Owls Head quarries; East Dorset Italian quarry.

Dyer quarry, description of . . . . . . . . . . 97 marble of . . . . . . . . . . . . . view of ..................... 45 See also Manchester breccia.

\section{E.}

East Dorset Italian quarry, description of... 105 marble of . ....................... 105

Eastman quarry, marble of.... 30,52, 54, 71, 89, 153 marble of, section of . . ............. 87-88 description of . . . . . . . . . . . . . . . 113-116 marble of................ 113-116,151-152 origin of

figure showing

section of .................... 113 structure of, figure showing........ 24 view of.
Egenter, Paul, on marbles .
Equinox Mountain, marble at........ 69, 97-98
Erosion, effects of $\ldots \ldots \ldots \ldots . . . . . . . .14$
Extent of marble deposits . ............. 157-159
F.

Faulting, occurrence and character of...... 83-84

Faults, occurrence and character of........ 83

Fisk quarry, description of . . . . . . . . . . . 145-146 marble of . . . . . . . . . . . . 145-146, 153, 154 section of .................. 145

Florence No. 1 quarry, caves in, view of..... 133 description of . . . . . . . . . . . . . . . 131-132 marble of . . . . . . . . . . . section of. . . . . . . . . . . . .

Florence No. 2 quarry, description of....... 129 marble of. . .............. $32,53,92,129,151$ section of prospect near, description of........... 130 marble of. .................... 130,151 structure of, figures showing . . ........ 24, 129

Florentine quarry, description of......... 132 marble of.................... 30,132,154 section of ........................ 91 view in ..................... 125

Florida, calcareous deposits in............ 22 Flowage, occurrence and character of...... . 79-80

Folding, erosion of................... 84 occurrence and character of........... 78-79 figures showing. . . . . . . . . . 24,78,79

Foley prospect, description of........... 112-113 marble of.................... 112-113,153

Folsom quarry, description of.............. 104-105 Foster quarry. See West Rutland quarries.

Fowler, marble near............. 71, 129-134 view at. ...................... 62

Freedley quarries, description of......... 105-107 marble of. ................. 52, 106-108, 150 section of . . . . . . . . . . . . . . figure showing............... 25

Freedleyville, sections near........... 106

G.

Geikie, Archibald, cited ........... 16,34,38-39 Geologic history, outline of. . ........... 74-77

Geologic map of western Vermont......... 9 of West Rutland belt................. 24 Geologic sections. See Sections.

Geology, areal, description of. ........... 62-64

Giampaoli, A., on marbles............... 14

Gilson quarry, view in................ 122 workings of..................... 117

Glaciation, effects of. . . . . . . . . . $\ldots \ldots \ldots .77,85$ effects of, plates showing... ........ 125, 132

Glossary of technical terms............. 162-164

Goodchild, J. G., cited................... 39

Goodell quarry, description of. ......... 137-138 marble of. ..................... 52, 137-138

Graphitic calcite marble, deposition of...... 74 description of..................... 39-40 thin section of, figure showing ......... 41 views of. ........................ 40,45

Greece, marbles from, analysis of......... 13 marbles of, description of. . ......... 25-27,54 description of, physical properties of.. 17, 18 


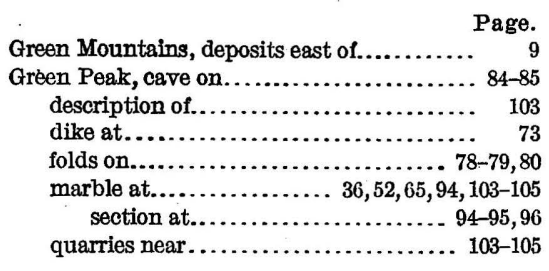

H.

Hager, A. D., cited........................ 48, 74

Hager, A. D., and Hitchcock, E., cited... 64-65, 73

Hazleton First National Bank, marble in,

view of............................... 124

Hematitic dolomite, description of ........... 43-45 thin section of, figure showing............ 44 view of .................................... 40

Henry, Joseph, cited . ....................... 37

Hirshwald, J., cited............. 19, 23-24, 37, 160

Historical geology, account of............... 74-77

Hitchcock, E., and Hager, A. D., cited... 64-65, 73

Hoernes, K., and Doelter, C., cited.......... 34

Hollister quarry, description of........... 133-134 marble of.............. 51, 53,54, 133-134, 151 section of ...................... 133 thin section of figure showing....... 134 view of.......................... 41

Hunt, T. S., cited....................... 35

Huntley quarry, description of........... 147-148 marble of........................ 147-148 thin section of, figure showing...... 148

I.

Isle la Motte, marble of............ 32-33, 145-146 marble of, analysis of ................. 48 description of..................... 47-48 formation of .................. 22, 36,47 thin section of, figure showing....... 47 quarries of........................ 145-146

Imperial quarry, description of ............ 108-109 marble at.......................... 109, 150 section of........................ 95

Inman Pond, calcareous deposits in........ 21

Italy, marble of, colors of................. 20 See also Carrara marble.

\section{J.}

Jasper marble, description of.............. 143 view of ............................. 45

Jimmo prospect, description of ............ 142 marble of........................... 142

Jointing, occurrence and character of ....... 83 Jordan Creek, Pa., limestone at............ 35-36 limestone at, analyses of.............. 36

$$
\text { K. }
$$

Kauffmann, - cited .

Kent \& Root quarry, description of .........

Kimball Monument, view of.

Klement, C., cited.

$$
\text { L. }
$$

Lake Champlain, marbles of, character of.... 28 color of .............................. 20 description of.......................... 43-46 physical properties of................. 17 See also Swanton; Monkton.
Page.

Landon quarry, description of........... 134-135 marble of............... 51,53, 92, 134-135, 151

Larsen, E. S., work of................... 10

Lee, Mass., marble of, analysis of ........... 13 marble of, character of................. 28 character of, figure showing ......... 28 strength of ...................... 16

Leicester Junction, marble from ............ 53 marble of, texture of................. 18,147 texture of, figure showing ........... 148

Leicester Marble Lime Co., quarry of........ 148

Lenox, Mass., folds at, figure showing....... 79

Lepsius, G. R., cited......... 13,15,17, 18, 26, 37,54

Lime marble, quarries of, descriptions of... 146-148

Limestone, nature of.................... 11-12 origin of $. . . \ldots \ldots \ldots \ldots \ldots \ldots \ldots \ldots \ldots, 21-22$ relation of, to marble................. 11-12

Linck, G., cited...................... 35

Lindenmann, Bernhard, cited........... 15,17

Literature, list of ....................... $59-60$

Loretz, H., cited...................... 34

M.

McGarry quarry, description of.......... 117 Magnetism, tests for ................... 161

Manchester breccla, description of.......... 48-49 specimen of, view of................... $\quad 45$ See also Dyer quarry.

Manchester Marble Co., machinery of........ 156 quarry of. See Freedley quarries.

Map, geologic, of western Vermont.......... 9 of West Rutland belt................. 30

Marble beds, age of ..................... $65-66$ cleavage of......................... 82-83 continuity of...................... 77 faults in........................... 83 flowage in ........................ $79-80$ folds in ............................ $78-80$ jointing in........................... 83 pinching of ......................... 80 relations of, to schist................. $80-81$ succession of ........................ 86-96

Marble belts, description of............... $60-85$ dikes in....................... 72-74,76 distribution of...................... 61-62 geologic history of.................. 74-77 zeologic principles governing.......... 77 geologic relations of.................. $63-66$ sections across......................6 67-69 plates showing................... 24 structure of......................... 67-72 succession of......................... 64-66

Marbles in general, analyses of............ 12-15 colors of ............................. 20 composition of...................... 12-16 definition of ......................... 12 literature of ......................... $55-60$ origin of ............................ 23-24 physical properties of................. 16-18 relation of, to limestone............... 11-12 texture of............................ 18-20

figures showing.................. 41,136 weathering of........................ 37-39 Sce also Calcite marble; Dolomite marble; Lime marble; Serpentine. 
Page.

Marble Ledge quarry, description of........ 141 Marble machinery, character of ............ 156

Marble quarries, descriptions of........... 97-149

Marbles of western Vermont, discussion of. . 39-164 varieties of, descriptions of ............ 39-51

Massachusetts, marble from.............. 29 marble from, thin section of, figure showing......................... 19

Memorial Continental Hall, view of........ 102

Metamorphism, progress of............... 76

Mica schist, occurrence and character of. .... 50-51

Microscopic examination, object of......... 160

Middlebury, marble near............. 139-141,154

Middlebury Marble Co. prospect, description of. ........................ 139-141 marble of......................... 140-141 thin section of, figure showing....... 140

Mofit, F. H., cited .................... 65, 106 work of......................... 9,68

Monkton, marbles of............. 45-46, 141-142 Monkton quarry (Columbian Marble Co.), description of................ 141-142 marble of

Monktoll quarry (Vermont Marble Co.), description of................... 141 marble of.......................... 141, 152

Morgan quarry, description of............ 116 views of ......................... 9,30

Mount Chaflee, dolomite at.............. $\quad 47$

Muscovite calcite marble, description of. . ... 41-42 views of. $41,45,124$

\section{N.}

New Columbian Marble Co. quarry. Sce Columibian quarry.

New York quarry, description of.......... 109 marble at............................. 83 section of ..................... 95, 110 view at............................ 72

Norcross-West Marble Co., machinery of.... 156 quarries of. See Valley quarry; Plateau quarry; Blue Ledge quarry; White Stone Brook quarry.

Norcross-West quarry, marble of . ......... 93-94 marble of, section of ................. 93

North Adams, Mass., marble near......... 64

Norway, marbles from, analyses of. ......... 13,14 marbles from, colors of.................. description of...................... strength of.

o.

Old Open quarry. See West Rutland quarries.

Open quarry, marble of. section at............................. 106

Otter Creek Valley, view across............ 62

Owls Head, marble near......... 31,94-95, 102,150 marble near, analysis of ............... 31 classification of ................. 150 description of..................... 43 folds in ........................ 80,103 figures showing. ............ 103, 132 pilasters of, view of................ 41 quarries near................... 102
Page.

Owls Head, marble near, section of ...... 94-95, 90 marble near, section of, figure showing .. $\quad 31$ quarries at, view in.................. 132

\section{P.}

Parker \& Pinckney prospect, description of.. 128 marble of.................. 128

Perkins, G. H., cited ................... 43, 44 Percolating waters, formation of dolomite by. $\quad 34$ Pfaff, F., cited............................ 35

Physiography, character of .............. 60-61 Pinching, occurrence and character of...... $\quad 80$ view of.............................. 132

Pine Hill, faults on..................... 83 marble near.................... 31-32, 48

Pittsford, marble belt near, view across...... 62 marbles of and near............ 30,32, 52, 129 description of .....................46-47 section of..................... 91-93,96 quarries at, views in............... 125, 132

Pittsford Italian quarry, marble of......... 92 marble of, section of .................. $\cdot 92$

Plateau quarry, description of............. 100 marble of...................... 100-102, 150 pilasters of, view of................ 44 tests of.......................... 101 view of ............................... 72

Plymouth, dolomite from................ 28

Polish, test for......................... 161

Porosity, determination of.............. 160-161

Prices, data on......................... 155

Proctor, marbles of and near......... 71, 126-128 marbles of and near, analysis of......... 13 section of...................... 89-91, 96 strength of....................... 16 quarries near...................... 126-128

Proctor quarry, description of........... 127, 128 marble of and near................ 30,127-128 section of....................... $89-90$ schist at............................. 82 structure of, plate showing............. 24

Prospect 255, description of............... 139 marble of.......................... 139

Prospecting, scientific rules for........... 159-160

Publications, former, mention of.......... 10

\section{Q.}

Quarry 238, description of ................ 135 marble of........................... 135 Queechy Lake, N. Y., calcareous deposits in. $\quad 21$

R.

Renard, A. F., on chalk................. 12

Renwick, N. G., cited................ 24, 39, 162

Ripley quarry, section in............... 118 structure at........................... 122 workings in......................... 117

Riverside quarry, description of........... 126 marble of........................ 124, 150

Round Hill, chrome mica schist of......... 50-51

Roxbury, marbles of............... 49, 153, 154 serpentine of ............... 9, 49-50, 148-149 view of......................... 45 
Page.

Royce quarry, description of . . . . . . . . . . . 138-139 marble of..................... 138-139

Rutland, geology neax. .................. 64 marbles of......................... 53,54

Rutland-Florence quarry, description of..... 116

\section{S.}

Schaller, W. T., cited............... 50, 138 work of......................... 9-10

Schist beds, bedding in................ 81 bedding in, figure showing............ 81

cleavage in ....................... 81

figure showing.................. 81

relations of, to marble.............. 80-81

plate showing................... 24

Scientific classification of marbles, table of... 155

Scope of bulletin....................... 9-11

Sections, geologic, description of ......... 67-72 plates showing.................... 24

Seely, H. M., cited.................. 65

Seipp, H., cited..................... 39

Serpentine, occurrence and character of. . . . . 49-50 quarries of, descriptions of........... 148-149 view of.

Shangrow quarry, description of......... 128 marble of........................ 128

Sheffield, Mass., marble from, texture of.... 19 marble from, texture of, figure showing.. $\quad 19$

Sherman quarry. See West Rutland quarries.

Snail shells, sections of, in marble.......... 22 sections of, in marble, figure showing.... 22

Solution, caves formed by ................ 84-85

Sonorousness, tests for................. 162

South Dorset, marble at............ 30,69,93 marble at, section of ............... 93-94 quarries near. .................... 98-103 view in..................... 72

Statuary, marble for, selection of .......... 162

Steiger, George, analysis by............. $\quad 31$ cited.......................... 40 work of........................ 9

Stokes, H. N., on marbles............... 14-15

Strahan; A., cited ...................... 34

Strength, tests for ................... 161

Structure, origin of ................... 67

sections of ..................... 67-72

plates showing................... 24

Sucker Brook, dolomite near............ 64

Sudbury, marble of................. 52,54

Sudbury breccia prospect, description of .... 139

Sutherland Falls quarry, marble of........ 30

Swanton, marbles near......... 9, 43-44, 142-145 marbles near, classification of...... 152-153, 154 thin section of, figure showing...... 44 view of ........................ 45 quarries near...................... 142-145

Swimmington quarry, description of...... 148

\section{T.}

Technical terms, glossary of . . .......... 162-164 Tests, character of................ 16, 160-162

Translucence, tests for ................. 161

Trap dikes, analysis of ....... 72 occurrence and character of.......... $72-74,76$ rue Blue quarry, description of $\ldots \ldots \ldots \ldots .124-126$
marble of............ $30,52,54,124-126,150,154$

pinching of ................... 80

section in ................... 87, 124

view of $\ldots \ldots \ldots \ldots \ldots \ldots \ldots \ldots \ldots \ldots \ldots, \quad 40$

structure of, figures showing. ......... 24, 125

view in........................ 125

Tunnel quarry, marble of . ............. 106

section at. ....................... 106

Turner quarry, description of........... 130-131

marble of. .................... 32, 130-131

section of...................... 130

structure at, figures showing......... 24, 131

Tyrol, marbles of, analysis of............ 14

marbles of, description of............. 27

strength of ..................... 16

\section{U.}

Umbrella quarry, description of ........... 116 Upper Gilson quarry. See West Rutland quarry.

Upper quarry, marble of . . ............. 106

section at. . . . . . . . . . . .

Uses, discussion of . . . . . . . . . . . . 156-157

\section{V.}

Valley quarry, description of . ........... 98-100 marble of . .................. 30,98-99,150

analysis of.................... 99

pilasters from, view of............ 44

thin section of, figure showing...... 99

Vermont Italian Marble Co. quarry, description of..................... 139

marble of........................ 139

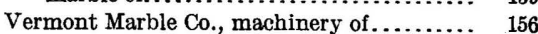

quarries of. See following: Morgan, Rutland-Florence, Wesı Rutland, Albertson, True Blue, Riverside, Proctor, Slangrow, Florence No. 1, Florence No. 2, Turner, Florentine, Hollister, Landon, Brandon Italian, Brandon Italian High Street, Monkton.

Van Hise, C. R., cited.................... 35

Vermont Valley, belt in, description of..... 64-65 location of . ...................... 61 Vogt, J. H. L., cited........... 16, 18, 19,30, 35, 37

W.

Watertown arsenal, tests of, on marble ..... 16

West Rutland, dike near................ 73 marble of and near. ............... 113-117 analysis of..................... $\quad 12$ beds of ....................... 30

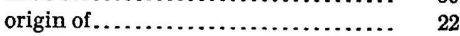
figure showing .............. 22 strength of $\ldots \ldots \ldots \ldots \ldots \ldots \ldots \ldots \ldots \ldots \ldots, 16$ texture of $\ldots \ldots \ldots \ldots \ldots \ldots \ldots \ldots \ldots . \quad 19$ views of $\ldots \ldots \ldots \ldots \ldots \ldots \ldots \ldots \ldots \ldots, 40,41$ quarries near..................... 113-117 See also Round Hill.

West Rutland anticline, beds east and west of, sections of ............... 86-89,96 
structure of............... 78,79,122

figure showing............... 122

West Rutland belt, geologic map of......... 24 location of....................... 61

West Rutland quarries, description of .... 117-123 marbles of.

analyses of $\ldots \ldots \ldots \ldots \ldots \ldots \ldots \ldots \ldots . \ldots \ldots$

classification of ............. 152,153-154

folds in...................... 78

sections of .................. 118

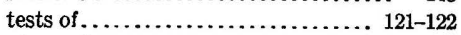

views of $\ldots \ldots \ldots \ldots \ldots \ldots \ldots \ldots \ldots . \ldots 123,124$
Page.

West Rutland quarries, views at......... 122

Whelden quarry, marble of............. 46

White Stone Brook quarry, description of . 107-108 marble of. . .............. 83-84, 107, 108, 150

section of.................... 94-95, 107

thin section of, figure showing ...... 108

Wilson portrait statue, view of ........... 123

Y.

Yamagawa, Kenjiro, cited............. 17

Z.

Zirkel, F., cited..................... 34 






Lithomount

Pamphlet

Binder.

Gaylord Bros. Inc.

Makers

Syracuse, N. Y.

PAT. JAN 21, 1908 


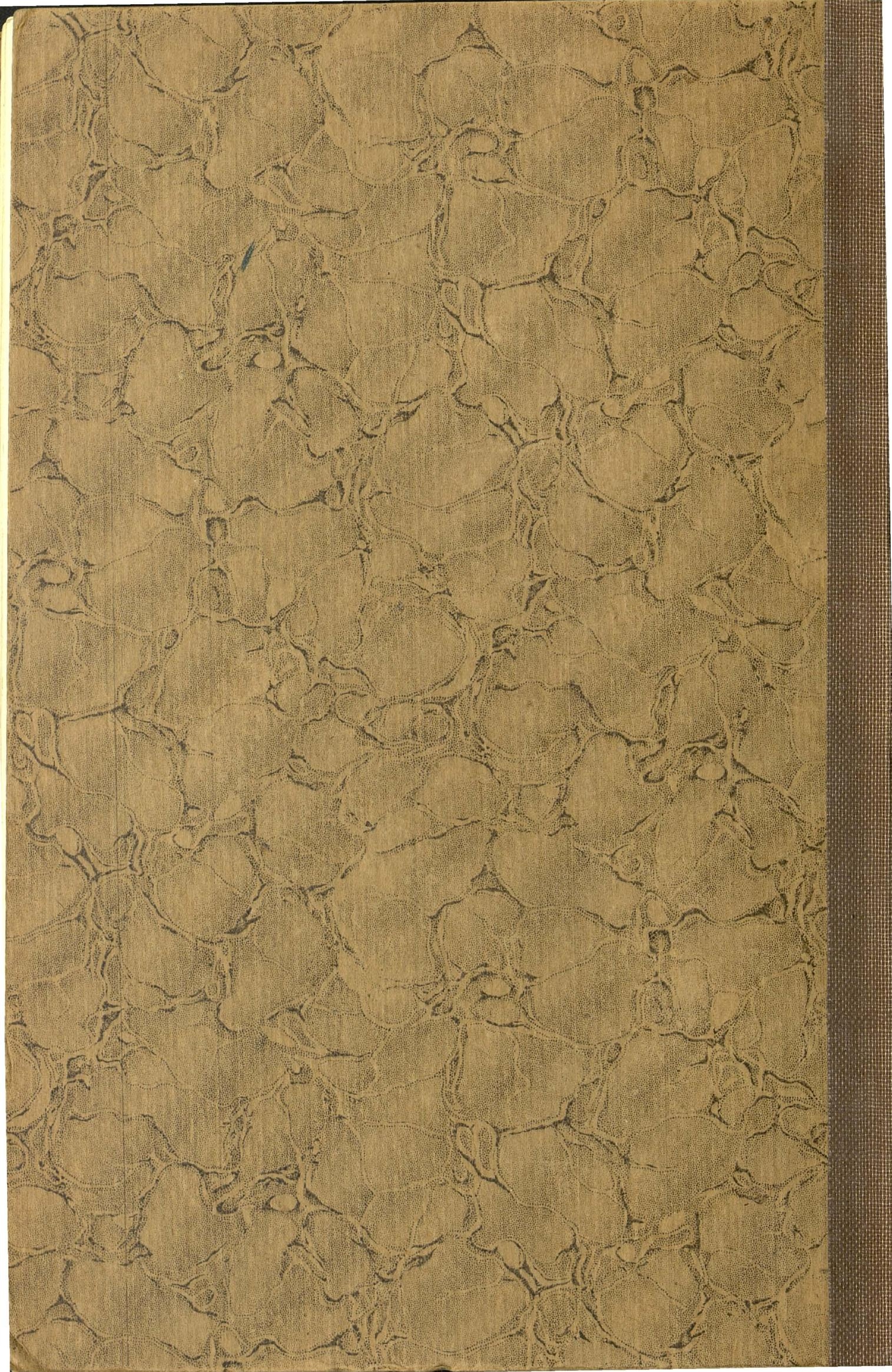

